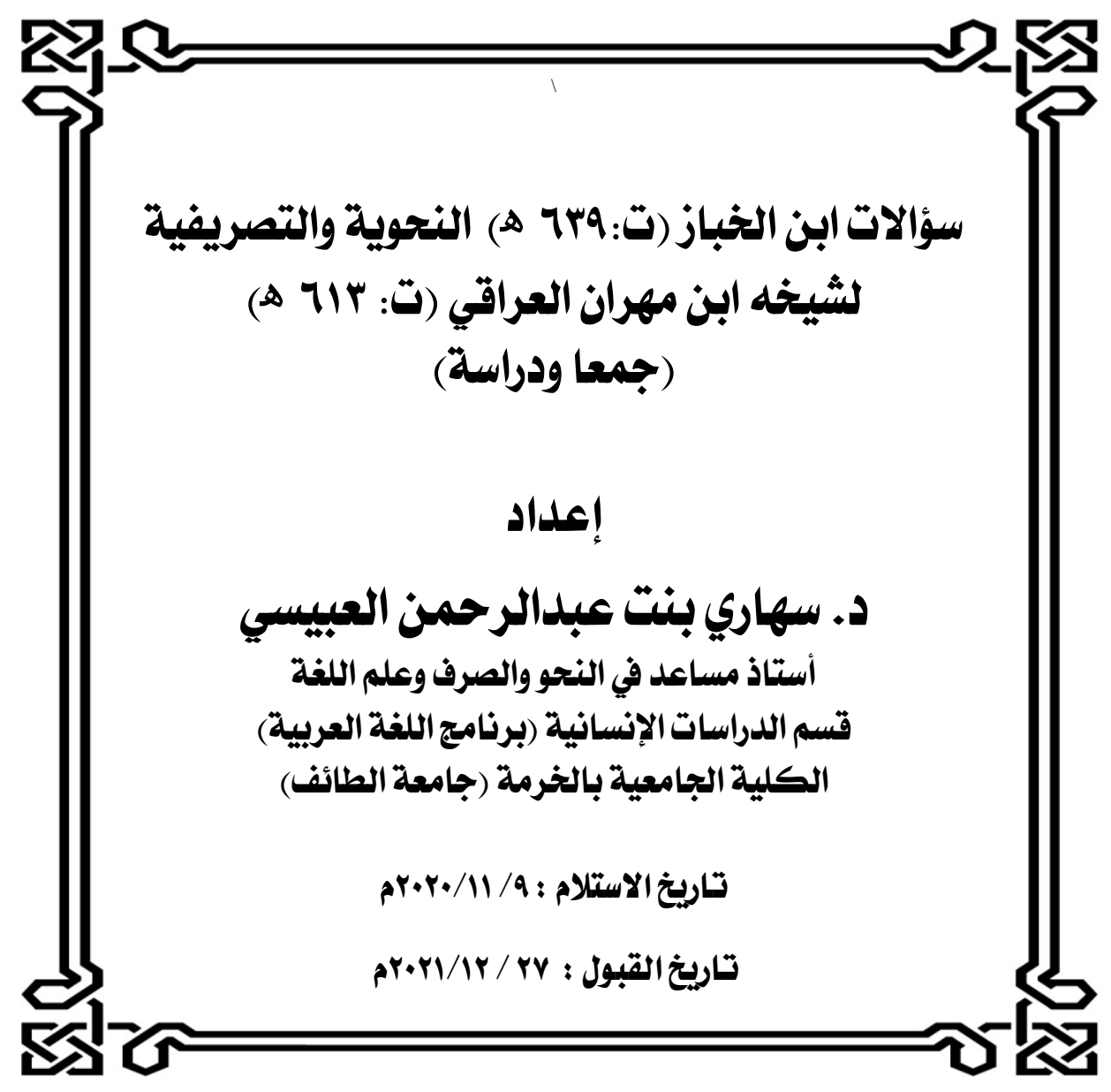





\section{شكر وتقدير}

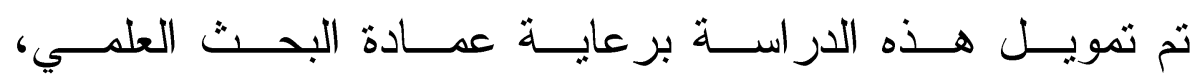

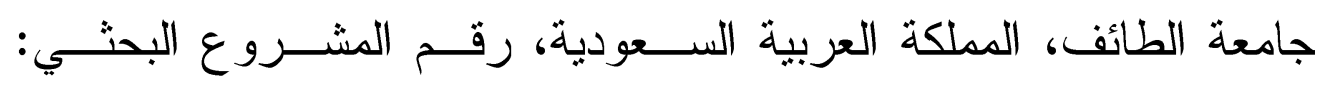

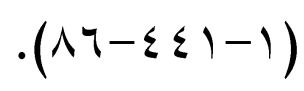

ولما كان برنامج داعم يستهدف أعضاء التدريس الجدد، وينطلع

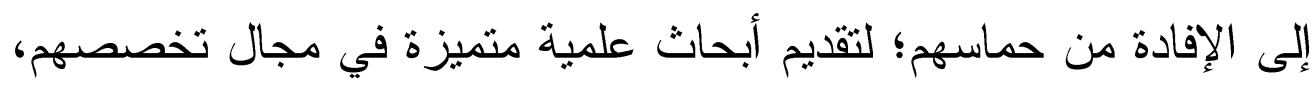

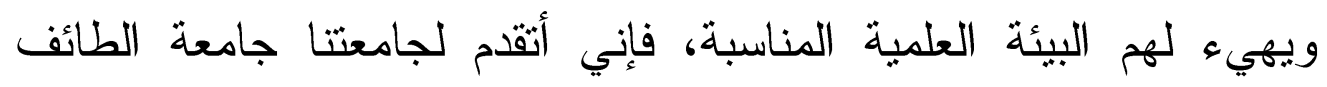
ممثلة في عمادة البحث العلمي بوافر الثكر و التقدير على إتاحة مثل هذه هنه

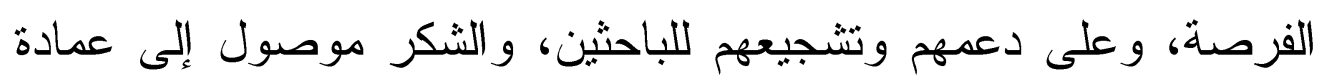
الكلية الجامعية بالخرمة التي تثمن جهود الباحثين، وتدفعهم لتنمية

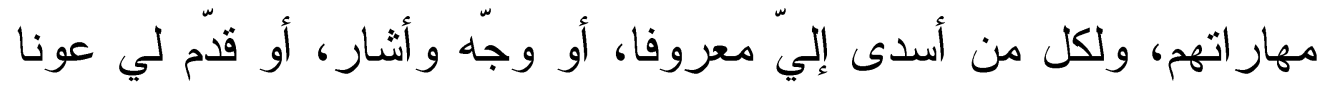

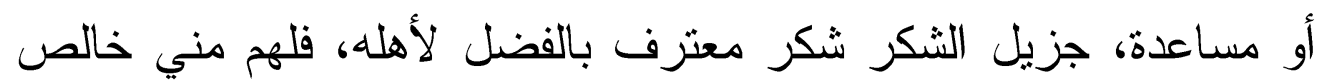
الدعو ات بأن بوفقهم الله في الدنيا والآخرة. 


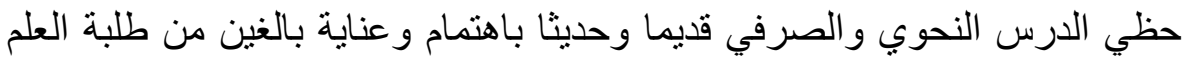

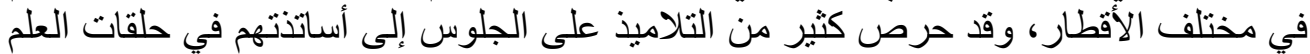

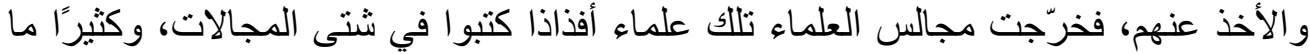

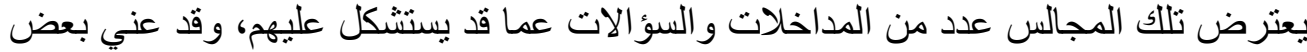

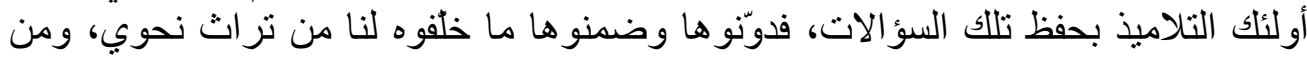

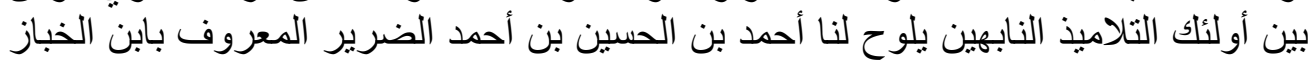

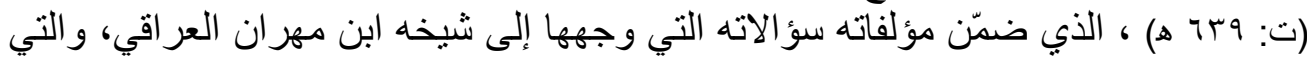

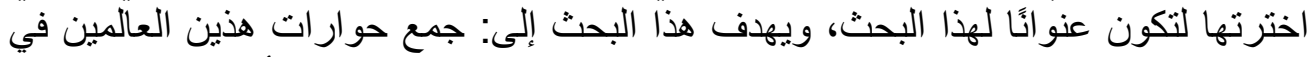

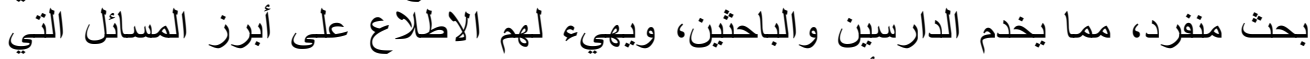

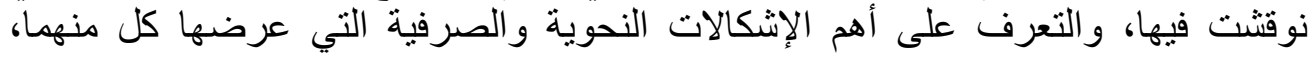

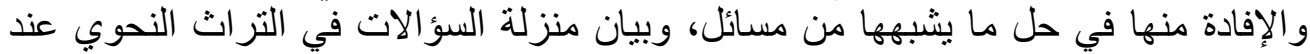

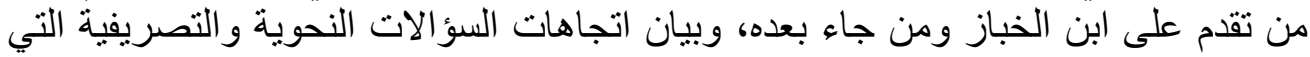

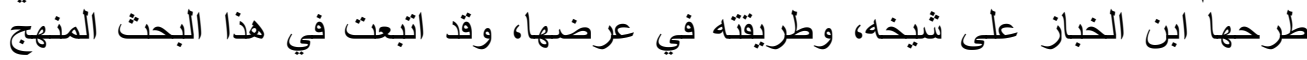

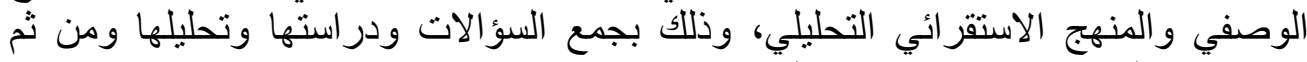
استخلاص النتائج وتضمينها خاتمة البحثث.

\section{ABSTRACT}

The grammatical and morphological lesson, past and present, received the attention and care of scholars in various countries. A considerable number of disciples were keen on joining their teachers in seminars, and occasionally substituting them. Therefore, many great and outstanding learned people, who wrote in various fields, graduated from the councils of scholars. Very often, these councils faced a number of inquiries and interventions about what may become problematic for them. Some of these disciples were keen on memorizing these inquiries, so they documented them and included them in what they left behind for us in the grammatical heritage. Among those witty disciples is Ahmed bin Al-Hussein bin Ahmed Al-Dharir, known as Ibn Al-Khabaz,, whose books included the inquiries he addressed to his sheikh, Ibn Mahran Al-Iraqi, which I chose to be the title of this research. This research aims to collect the dialogues of the two scholars in an independent research, which serves scholars and researchers, and prepare them to show the most important issues discussed, to identify the most important grammatical and morphological problems presented by each of them, to benefit from them in solving similar issues, and clarifying the status of the inquiries in the grammatical heritage of those who preceded Ibn Al-Khabbaz and who succeeded him, and to explain the directions of the grammatical and morphological inquiries raised by Ibn Al-Khabbaz to his Sheikh, and the method of presentation. Both the descriptive and the analytical inductive approaches are followed in this research in collecting, analyzing and drawing the findings, and then including them in the conclusion. 


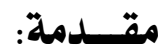

الحمد اله الديان، خالق الإنسان، الذي علمه البيان، و الصلاة و السلام الأتمان

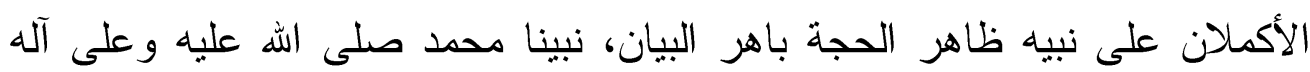

وصحبه ما تعاقبت الأزمان، وبعد:

فقد حظي الدرس النحوي و الصرفي قديما وحديثا - شأنهما شأن بقية العلوم-

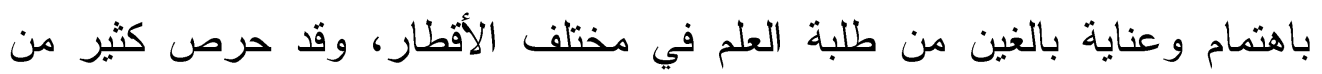

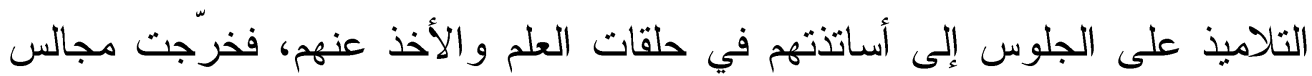

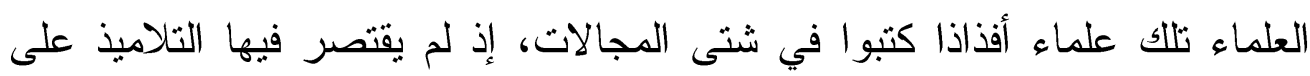

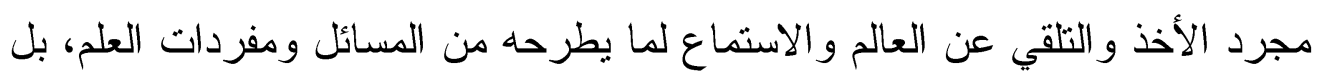

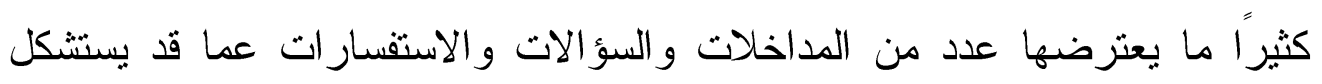

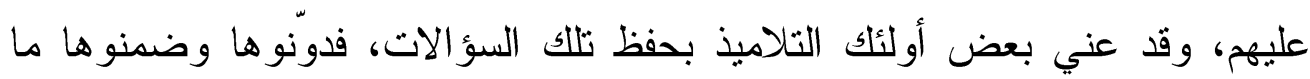

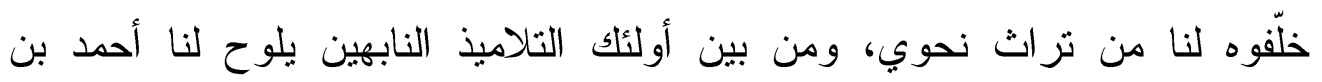

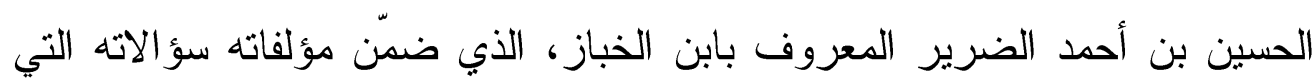

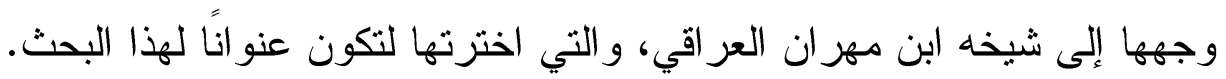

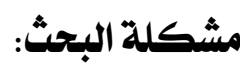

تكمن مشكلة البحث في السؤال الرئيس الآتي:

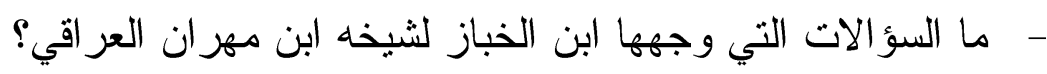
ويتقر ع عن هذا السؤال عدد من الأسئلة على النحو الآتي:

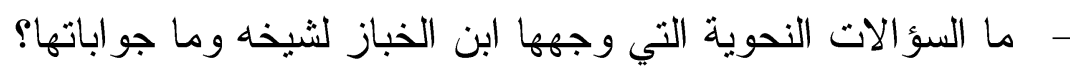

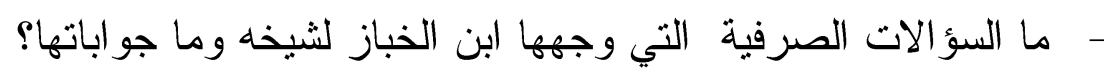

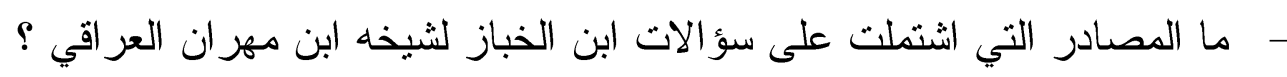

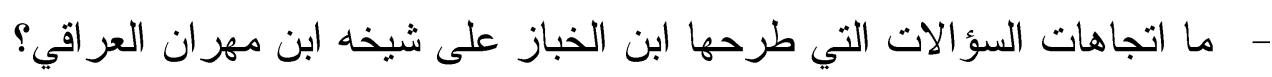

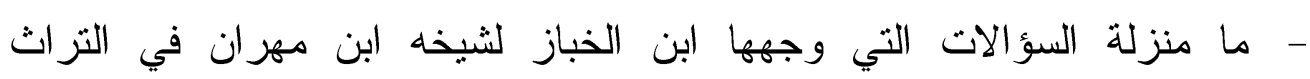

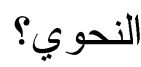

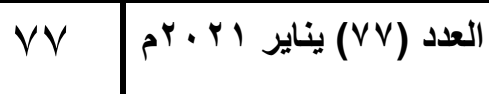




\section{أسباب اختيار موضوع البحث:}

- كون هذا الموضوع يقوم على حوار مباشر بين عالمَـين لكل منهما مكانته العلمية وهما: ابن مهران العر اقي، وتلميذه ابن الخباز .

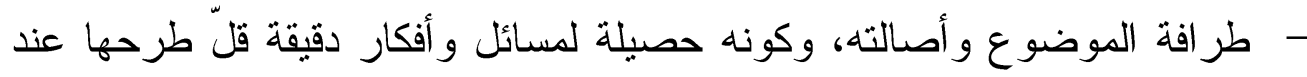
النحاة.

- أن كلا العالمين من العلماء الذين برزوا في أوائل القرن السابع، وهو قرن نشطت فيه الدر اسات النحوية، وبرز فيه الاهتمام بالعلة النحوية. - القيمة العلمية للسؤالات التي طرحها ابن الخباز على أستاذه ابن مهران. أهداف البحث:

\section{يهدف هذا البحث إلى تحقيق ما يأتي:}

- جمع حوارات هذين العالمين البارزين: ابن الخباز، و وابن مهران العراقي في بحث مستقل، مما يخدم الدارسين والباحثين، ويهيء لهم الاطلاع على أبرز

$$
\text { المسائل التي نوقشت فيها. }
$$

- - التعرف على أهم الإشكالات النحوية و الصرفية الني عرضها كل منهما، والإفادة منها في حل ما يشبهـ الغ من مسائل. - الوقوف على فن الحوار في المسائل النحوية، وكيفية الإجابة على المسائل النحوية، وكيف كان منهج العلماء في ذلك. - - بيان منزلة السؤالات في التزاث النحوي عند من تقدم على ابن الخباز ومن جاء بعده. - - بيان اتجاهات السؤالات النحوية و التصريفية التي طرحها ابن الخباز على شيخه،

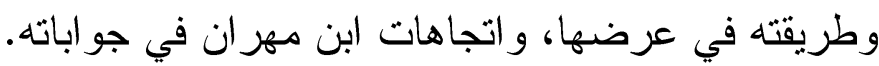

أهمية البحث:

\section{تكمن أهمية هذا البحث فيما يأتي:}

- أن دراسة السؤالات تقبد في جمع الأجوبة التي يتلقاها التلميذ عن شيخه، فهي من أهم ما يُرجع إليه في علم النحو. 
- أن هذه السؤالات وجواباتها تشنثل على كثير من المعلومات التي ربما لا نجدها في غير ها من المصادر • - أنها تبرز التفاعل بين التلميذ النبيه في استخراج المعلومات من شيخه، ثم المحاورة مع الثيخ في جو ابه الذي طرحه.

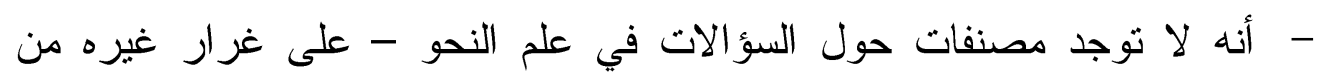

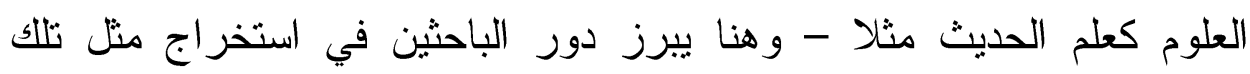
السؤالات من بطون المؤلفات، ودراستها، وبيان بعض المسائل التي ربما لم لم دون

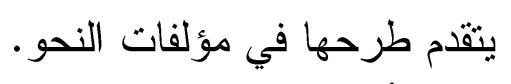
- أنه لم يُسلّط الضوء على هذه التساؤلات من قبل، ولم تُرسَس شخصية ابن مهران قبل هذا البحث، مما قد يكون إضاءة للباحثين لدراسة هذه الشخصية، وفتح هذه مجالات أخرى للبحث العلمي.

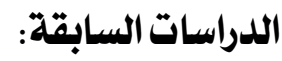

هناك بعض الار اسات التي تعرضت للسؤالات والجوابات ومنها: - - سؤالات أبي علي الفارسي النحوية لشيخه أبي بكر بن السر اج جمعا ودر اسة، د. د. عبدالله بن محمد النغيمي، نشر مجلة العلوم العربية بجامعة الإمام محمد بن بن بن

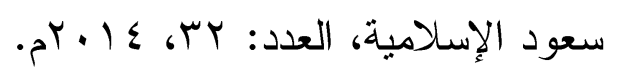
- سؤالات أبي العباس المبرد النحوية والتصريفية لثيخه أبي عثمان المازني جمعا ودراسة، د. عبداله بن محمد النغيمشي، مجلة العلوم العربية والإنسانية، جامعة الية القصيم، المجلد الخامس، العدد الثاني، (سبع أه - r ا • rم).

وهناك أيضا دراسات تتعلق بفكر ابن الخباز، ومنها:

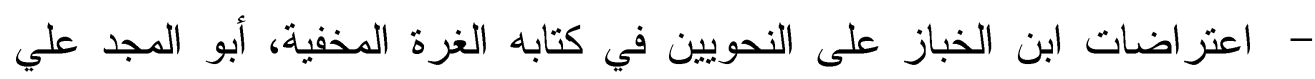
حسن، رسالة ماجستير في كلية اللغة العربية، جامعة الأزهر، المنصورة،

$$
\cdot r^{r} \cdot 1
$$


- مآخذ ابن الخباز على ألفية ابن معط، د. علي بن إبر اهيم السعود، مجلة العلوم

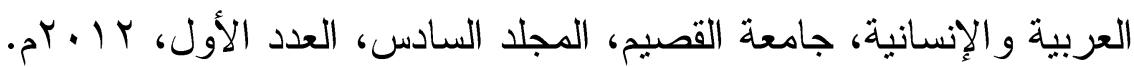

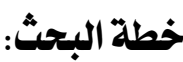

رسمت" لهذا البحث خطة اشتملت على تمهيد وخمسة مباحث، تسبقها مقدمة

وتقفو ها خاتمة بأهم نتائج البحث، وذلك على النحو الآتي:

المقدمة: تشنمل على أهمية الموضوع، و أسباب اختباره، و وأهداف البحث، البه،

ومنهجه، وأهمية البحث، وخطنه.

التمهيد، ويتضمن ما يأتي: ولهيك

أولا: التعريف بابن مهزان العراقي.

ثانيا: التعريف بابن الخباز بإيجاز .

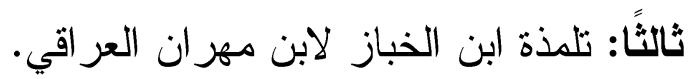

المبحث الأول: السؤالات النحوية وجو اباتها.

المبحث الثاني: السؤالات الصرفية وجو اباتها.

المبحث الثالث: مصادر السؤالات المجموعة.

المبحث الر ابع: اتجاهات السؤالات النحوية و التصريفية وجواباتها.

المبحث الخامس: منزلة السؤالات في التراث النحوي.

ثم الخاتمة: وفيها أبرز نتائج البحث. منزه

وقد اتبعت في هذا البحث المنهج الاستقرائي التحليلي، والمنهج الوصفي، وذلك بجمع السؤالات ودراستها وتحليلها ومن ثم استخلاص النتائج، مع مراعاة تخريج الأقو ال و الثو اهد من مصادرها، ورتبت المسائل فيه على ألفية ابن مالك.

هذا وأسأل الله التوفيق و السداد إلى طريق الرشاد، وصلى الله وسلم على نبينا

$$
\text { محمد و على آله وصحبه وسلم. }
$$




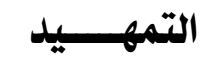

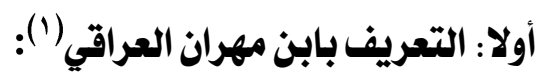

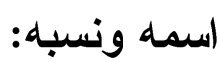

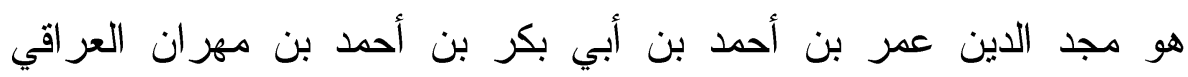

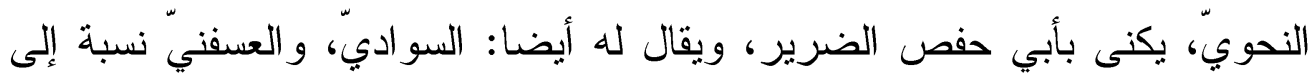
(عين سفنة) و هي قرية بنو احي الموَصْل.

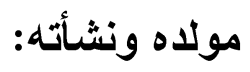

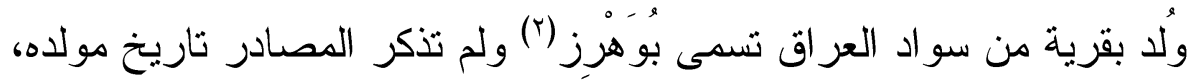

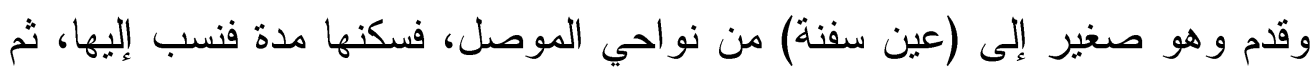
ورد مدينة الموصل فنشأ فيها وحفظ بها القرآن، وطلب العلم، و لازم الثيخ أبا الحرم

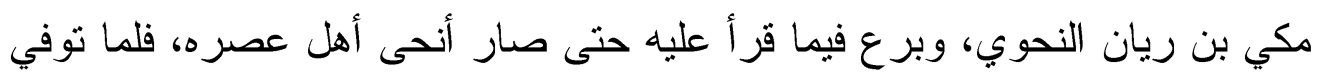
شيخه أبو الحرم قام مقامه، وجلس مكانه، وأقرأ ألناس النحو و الآداب.

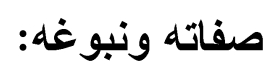

كان مفرط الذكاء، سريع الحفظ، قوي النفس وقت القراءة عليه، وقيل: إنه

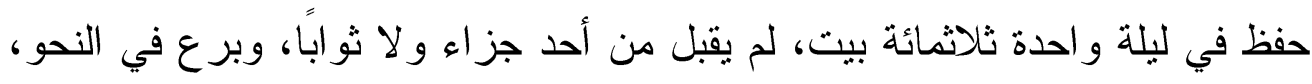

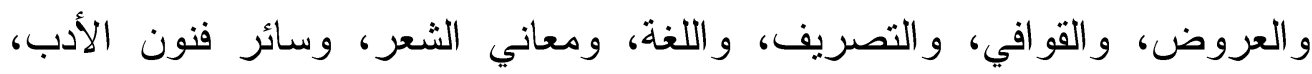

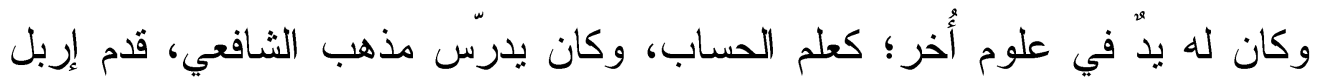

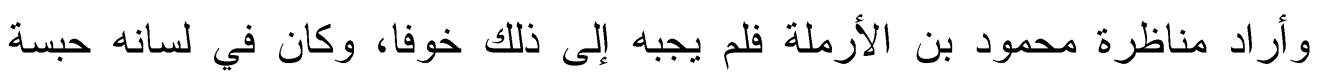
عظيمة، و عنده تقل في كلامه لا يكاد يبين.

تصدر و أفاد خلقا كثيرا، و انثال عليه جماعة كثبرة ممن هو في طبقته من

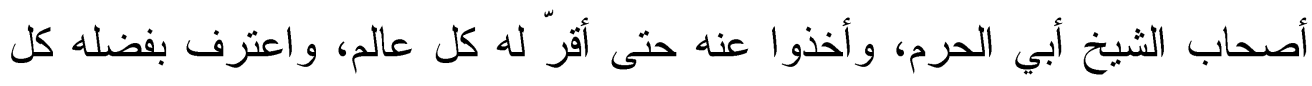

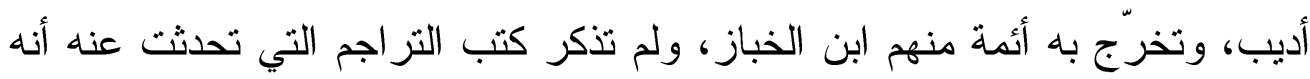
ترك شيئا من المؤلفات رغم نبو به فئه في العلم.

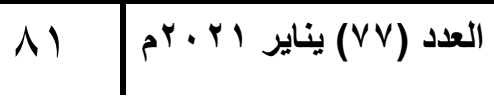


كانت وفاته في سنة سآ هـ بالموصل، يوم عيد الفطر، ودفن ظاهر البلد

بمقبرة المعافى بن عمران .

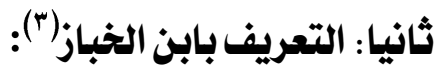

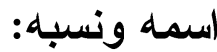

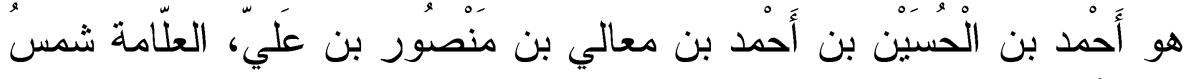

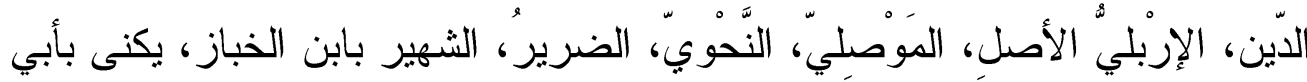

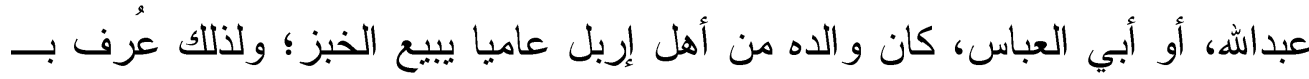

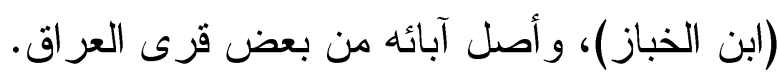

\section{مولاه ونشأته وثُقاقته:}

ولا ابن الخباز في (إربل) ونشأ في (الموصل) ولذلك يقال في كتب النز اجم:

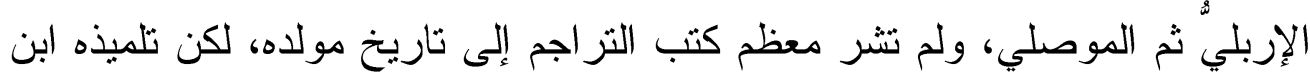
الثعار ذكر أنه "ولد في اليوم الثاني عشر من جمادى الأولى سنة نسع وثمانين

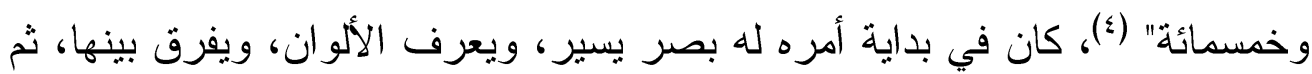

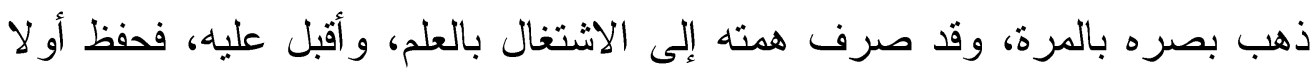

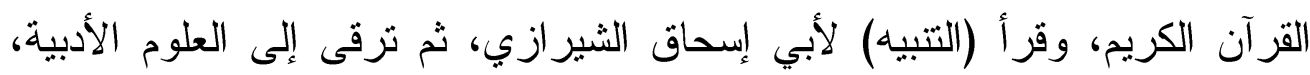

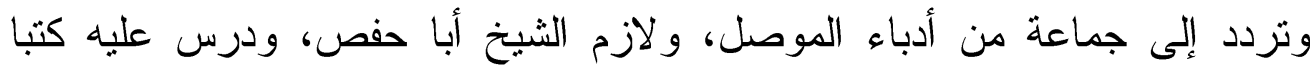

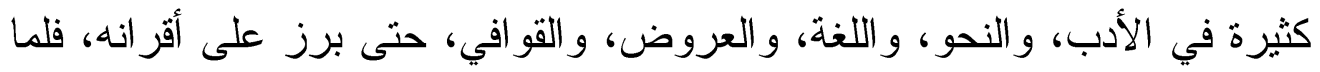

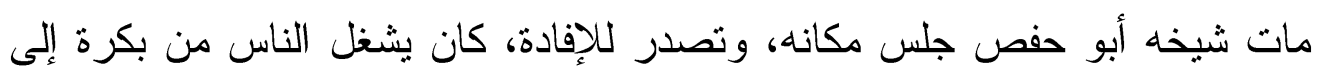

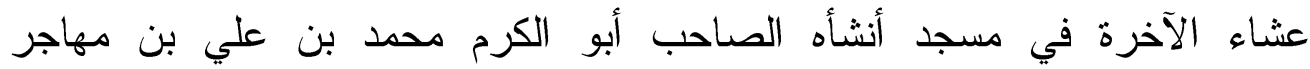

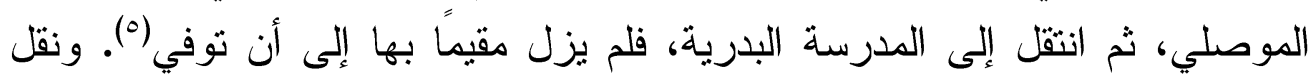

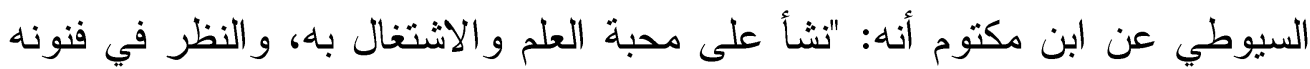

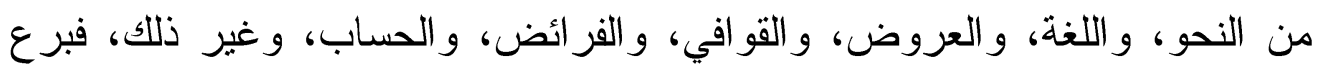

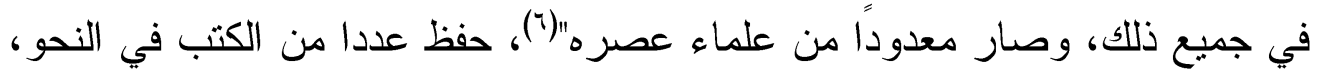

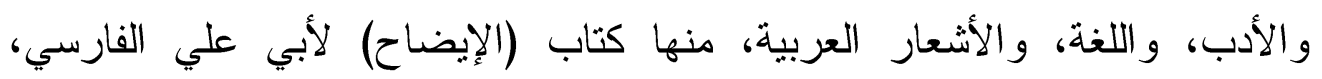


وكتاب (المفصل) للزمخشري، وكتاب (الكافي في علم العروض و القو افي) للتبريزي،

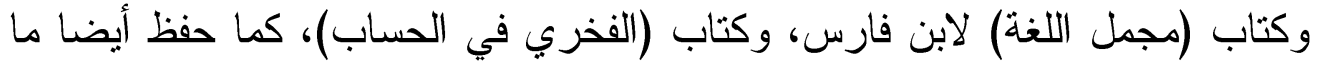

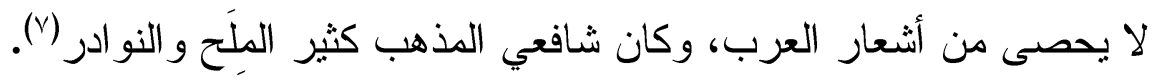
كلام العلماء فيه: نال ابن الخباز مكانة علمية مرموقة، وتمكن في العلم تمكنا دفع جملة دن

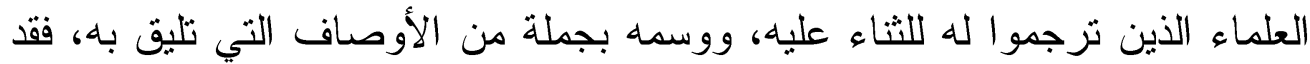

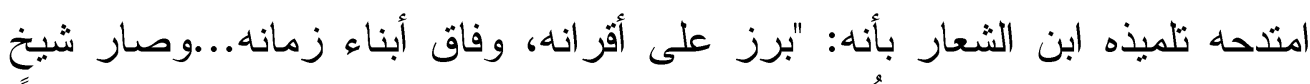
وقته، وحبر مصره، ولم يز في زمانها فئه أسرع حفظا منه، ولا أكثر استحضاراً

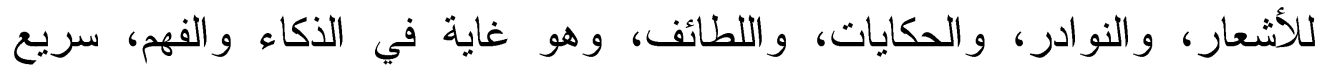

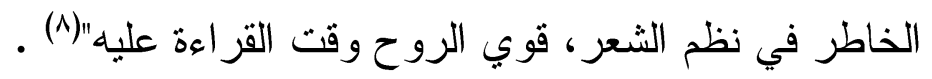
وذكر جمع من العلماء أنه صاحب التصانيف، وأنه كان أستاذا و إماما بارعًا(9).

\section{شيوخه:} صرّح ابن الخباز في كتابه (توجيه اللمع) بشيخه الذي طالما لازمه ونهل من علمه وهو الثيخ: أبو حفص عمر بن أحمد بن أبي بكر بن مهران العراقي (·)، ولم فئه تذكر معظم المصادر غيره عند ترجمة ابن الخباز، لكن ابن الشعار، تلميذ ابن الخباز

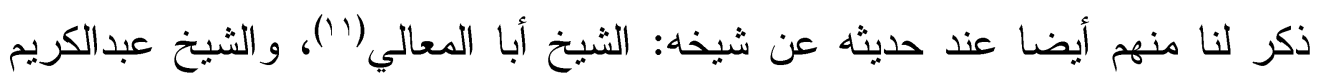
بن أحمد بن محمد الضرير، المعروف بــ(ابن حرمية)(ז'ا)، وممن أورده ابن الشعار

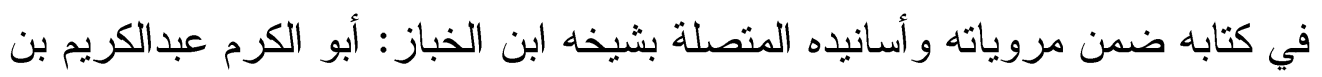
يوسف بن الحسين الموصلي (r').

تلاميذه: تصدر ابن الخباز للتنريس بعد وفاة شيخه ابن مهزان العراقي، فأخذ مكانه، و انهال عليه التلاميذ من كل صوب، إذ "رحل الطلبة من البلاد إليه، وتز احموا؛ لكثرة

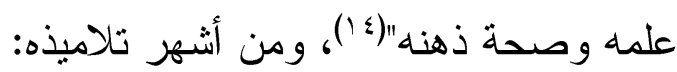


- المبارك بن أحمد بن الشعار الموصلي، صاحب كتاب (قلائد الجمان)، والذي يعد من أفضل من تزجم لابن الخبار، ونقل لنا أشعاره.

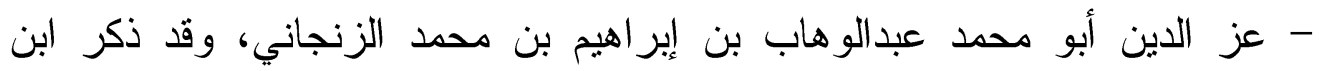

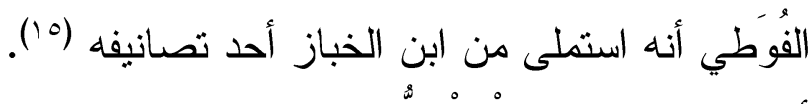

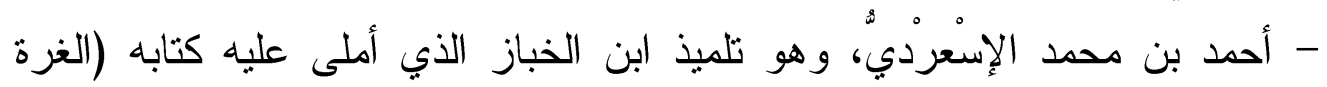

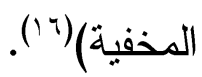

- محمد بن ميكائيل بن أحمد الفرضيٌ النحوي، وقد ذكر السيوطي أنه أملى على ابن

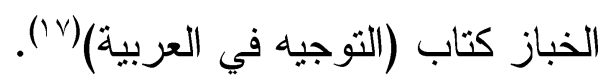

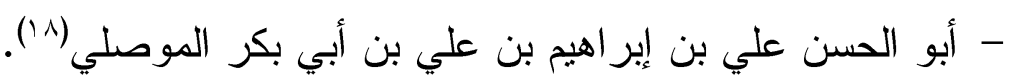

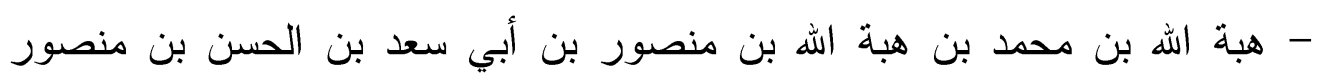

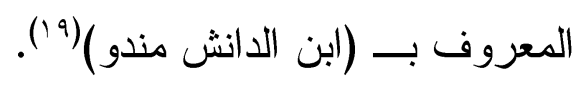

- أبو عبداله محمد بن أحمد بن عمر بن أحمد بن أبي شاكر (r.). آثـاره:

خلف ابن الخباز مصنفات متعددة، أثرت المكتبة العربية، وهي تذل على

غزارة علمه، و اتساع معرفته، ومما وصلنا منها ما يأتي:

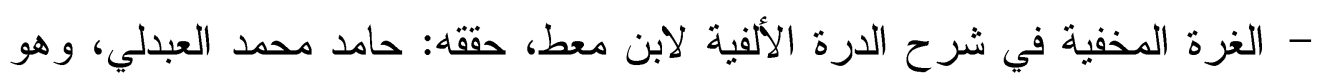

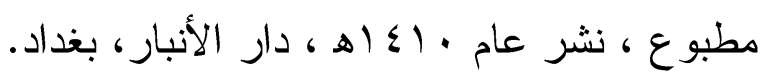

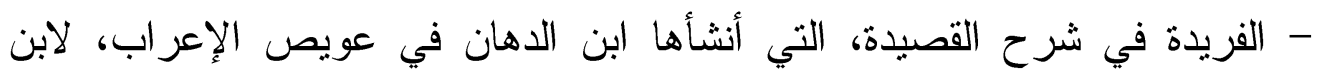

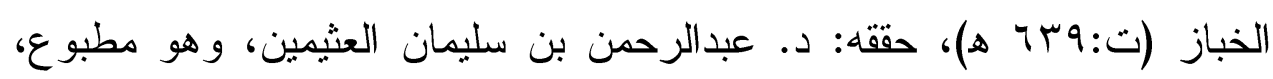
نشر عام • (ع أهـ ، مكتبة الخانجي، القاهرة. - النهاية في شرح الكفاية، وهو شرح لهن كفاية الإعراب عن علم الإعراب، حققه:

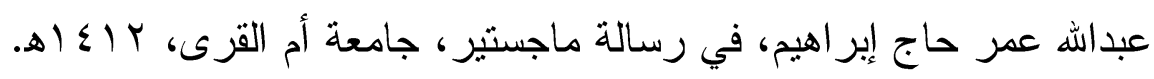

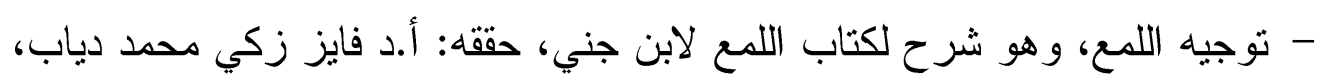

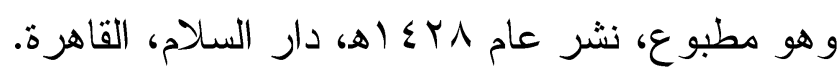


كما ذكرت كتب التزاجم لله مصنفات أخرى متعددة (اr)، لم يصلنا منها شيء، ومنها: الجوهرة في مخارج الحروف، الإلماع في شرح لمع ابن جني، تحرير المقياس في تفسير القسطاس، قواعد العربية، نظم الفريد في شرح التقييد، شرح

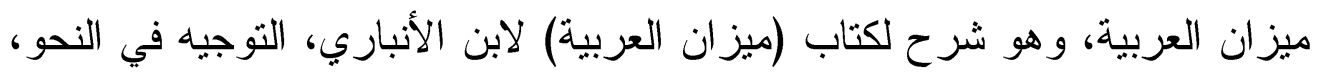
مناقب الثيخ ابن قدامة (إبر اهيم بن عبداله الحنبلي).

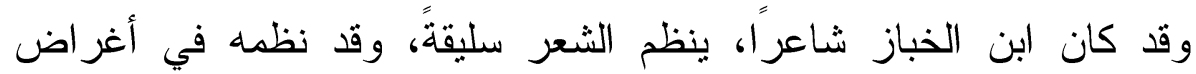
متعددة: كالمدح، و الرثاء، و الغزل، و الشكوى من الزمان و أهله، و غير ذللك، وقد حفظ ونط

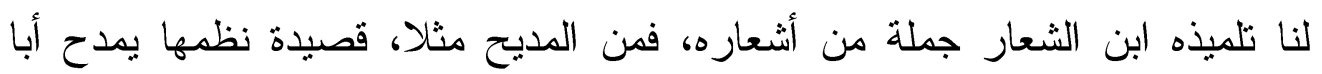

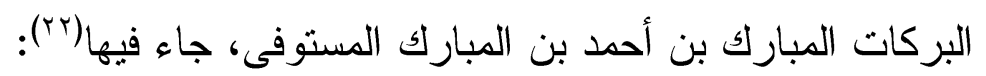

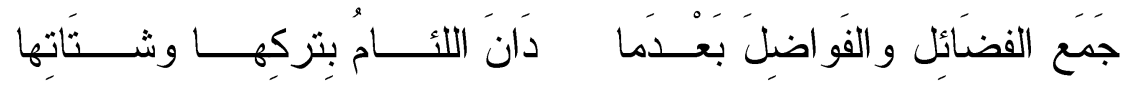

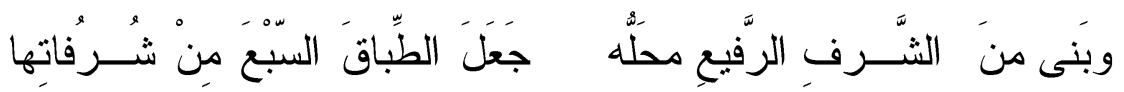

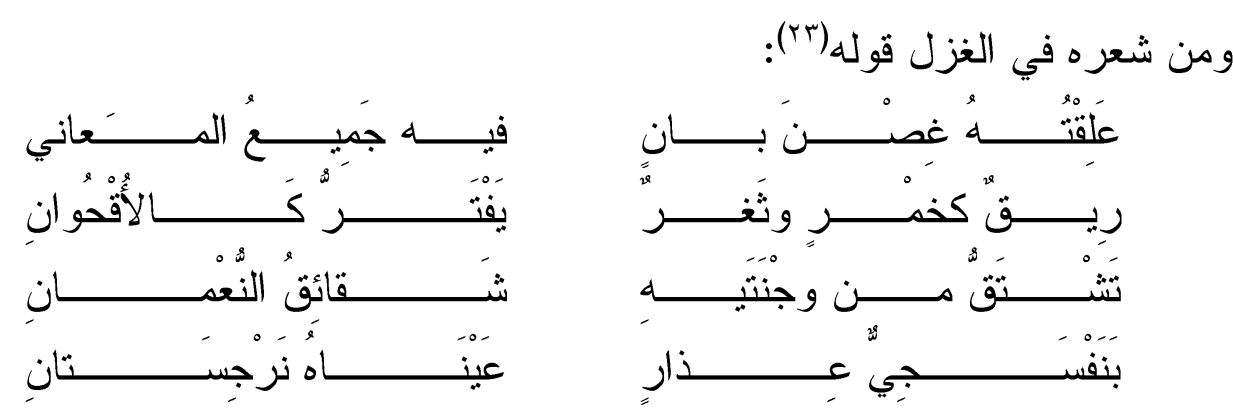

ومن شعره في الرثاء، قوله في رثاء أبي إسحاق إبراهيم بن عبدالكريم الحنفي (r) (ب)

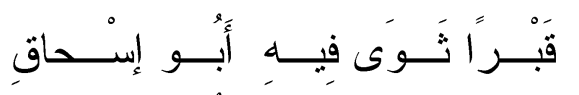

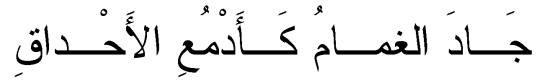

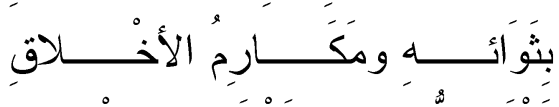

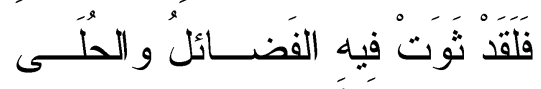

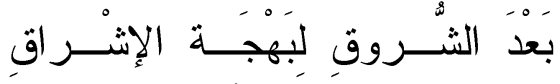

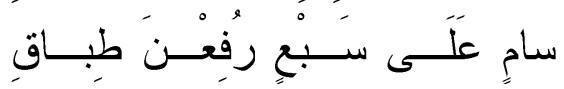

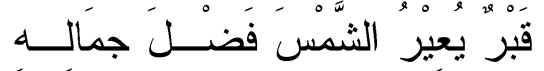

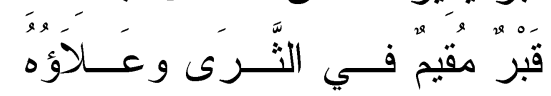


وله أيضا شعر في الألغاز ومشترك اللغة، وقد أورد له ابن الشعار قصائد

$$
\text { أخرى طويلة في مختلف الأغر اض(ro(). }
$$

وفاته:

توفي ابن الخباز في الموصل، في شهر رجب، وقد اختلفت المصادر في تاريخ

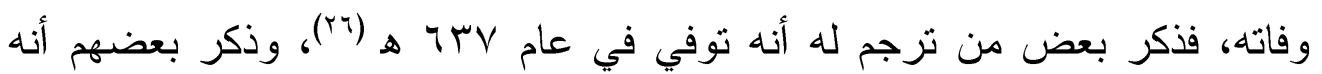

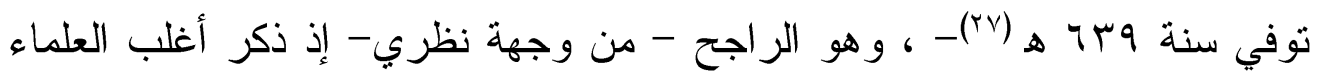

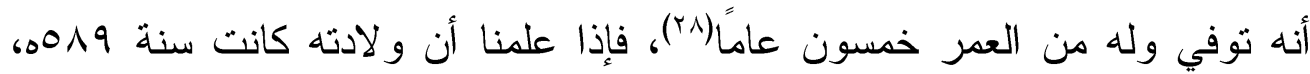
فان وفاته تكون وفقا لذلك عام وسب هـ هـ

\section{ثالثا: تلمذة ابن الخباز لابن مهران العراقي:}

لم تسهب كتب التزاجم - التي وقفت عليها - كثير ا في ذكر ما يتعلق بالثيخ ابن مهران العراقي، لكنها أثشارث إلى ملازمته لثيخه مكّي بن ريان النحوي، و أنه

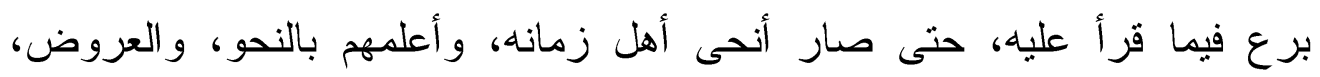

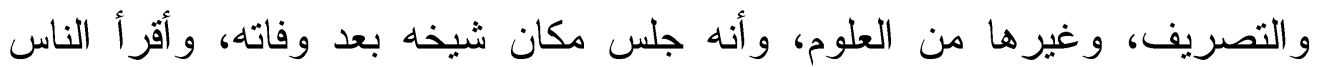

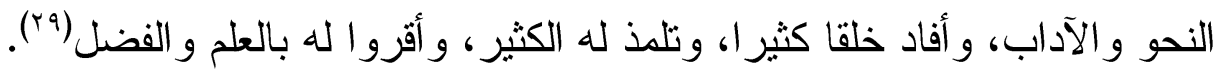
ولم أجد في تلك الكتب بيانا بأسماء من تلمذوا له، ولكن لعل ما يفيدنا هنا مما ذكروه، هو أنه كان أنحى أهل عصره، و أنه تصدر لتعليم النحو بعد وفاة شيخه. وفي الجانب المقابل عند تتبعي لترجمة ابن الخباز، وجدت من ذكر أنه تلمذ

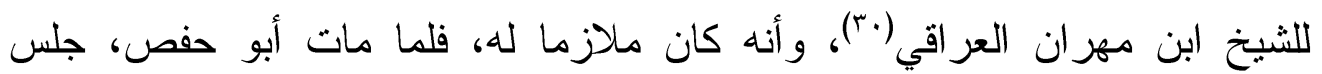
مكانه وتصدر لإفادة علم الأدب، والعربية، وغيرها من العلوم، كما ذكر السيوطي

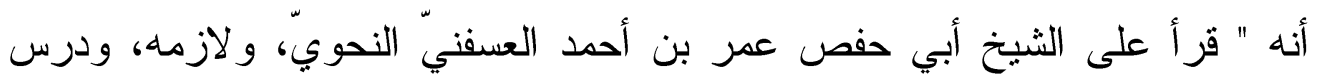

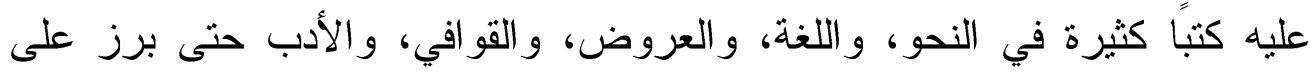

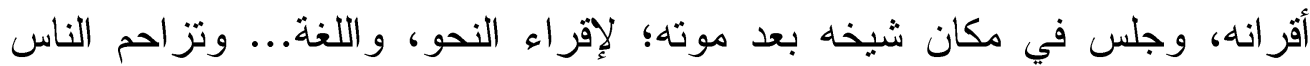


ولم أجد في كتب التزاجم إثنارة إلى الفترة الزمنية التي بدأ فيها ابن الخباز

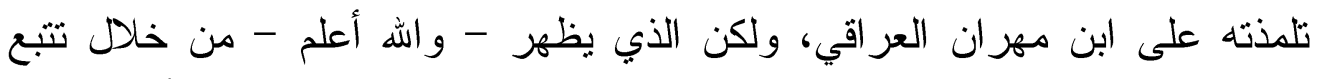

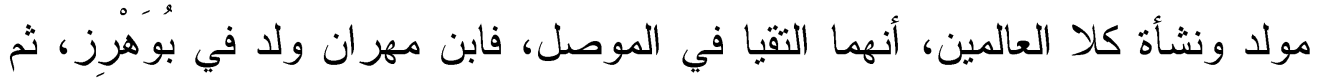

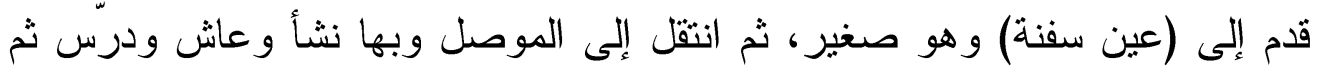

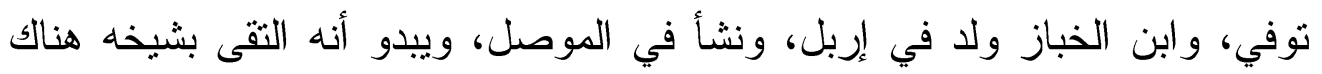

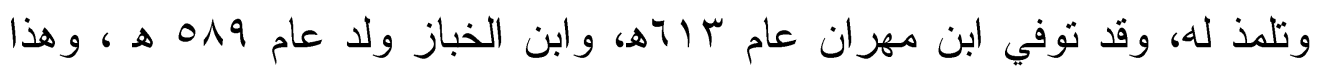

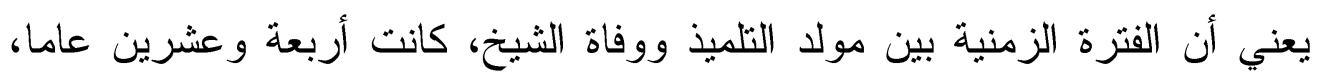

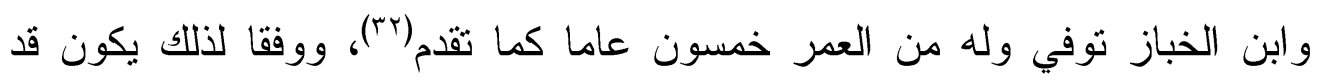

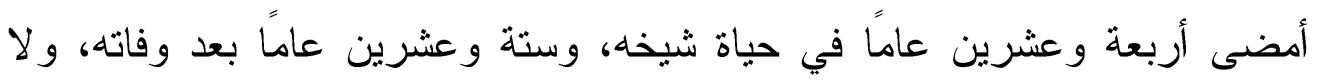

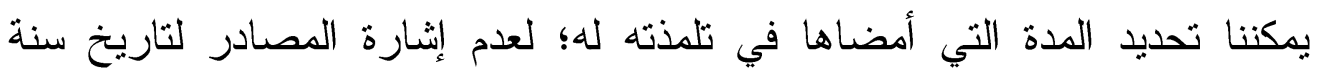

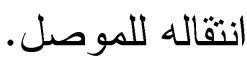

وقد كان ابن الخباز يجلٌ شيخه أبا حفص كثير ا، ويشهد بفضله، ويثي عليه،

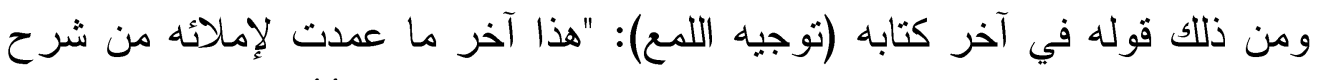

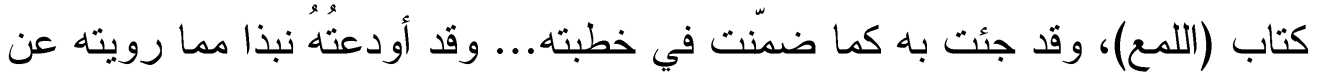

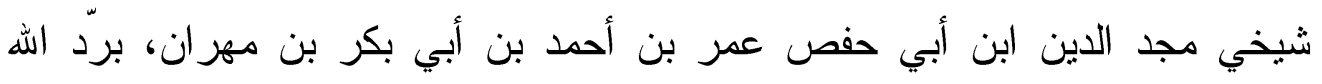

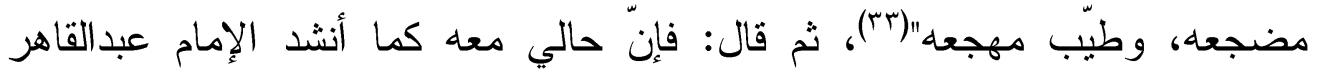

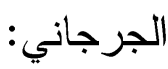

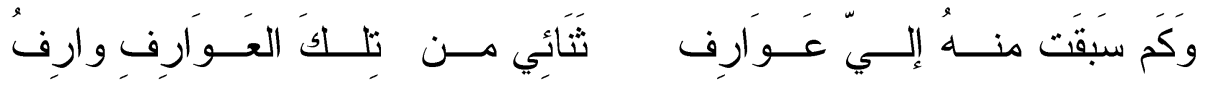

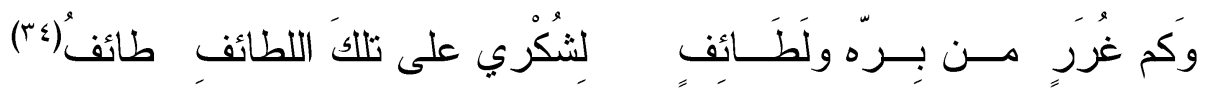

ولم يذكر ابن الخباز اسم شيخه صراحة سوى في هذا الموضع من كتاب

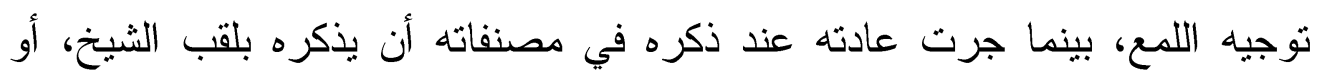
شيخنا؛ إجلالا له، ثم يتبع هذا اللقب بالترحم عليه.

NV يناير IV العد TV) 
وقد لاحظت أن ابن الخباز يحفظ في مصنفاته محاوراته مع شيخه ابن مهران العر اقي، إذ يضمن مناقثاته للمسائل كثير ا من آراء شيخه أبي حفص، فهو

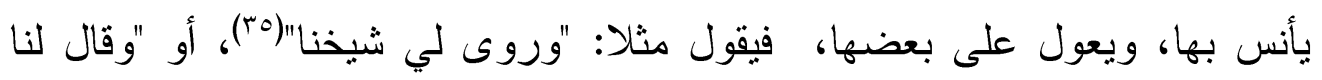

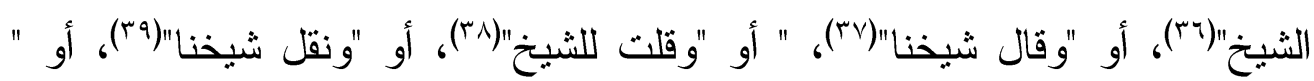

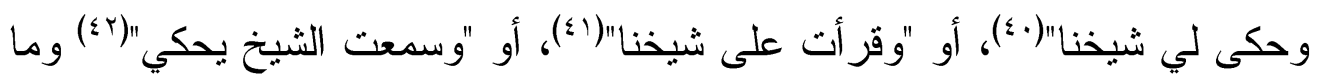
أثبهرها من العبار ات التي تفيد تلقيه عن شيخه مباشرة، وهو في كل ذلك إما أن يورد

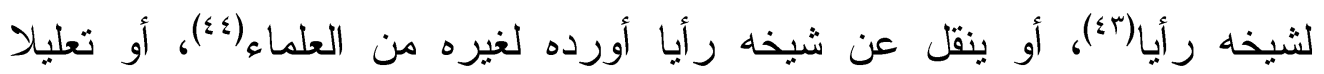

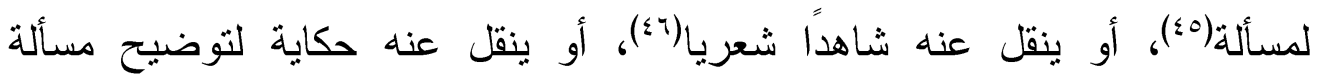
نحوية(V)، إلى غير ذلك مما يظهر حضور الثيخ في مؤلفات تلميذه، ونأثزه به. فهو يمثل الطالب النجيب الذي يناقش أستاذه، ويسأله عما قد يشكل عليه،

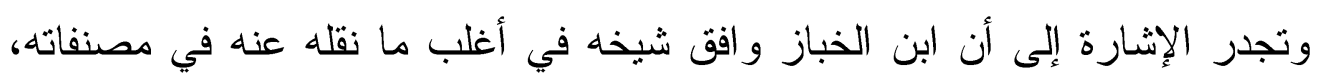

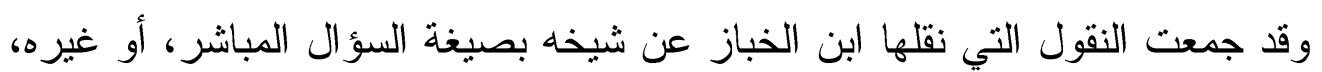

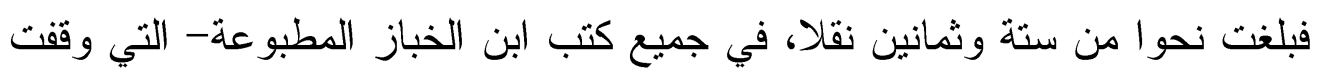
عليها- دون حذف المتكرر منها، وسأقتصر في هذا البحث على عرض ومناقشة ما طرحه ابن الخباز على شيخه بصيغة السؤال المباشر، ومجملها اثثان وعشرون ونيان سؤ الا.

وقبل أن أختم الحديث عن تلمذة ابن الخباز على شيخه ابن مهران، تجدر

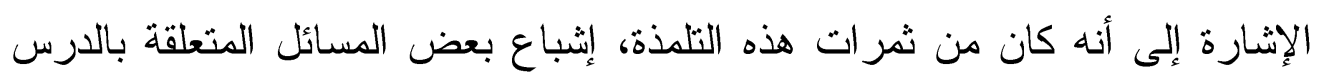
النحوي أو الصرفي بالبحث و المناقشة، كما أنه كان بثني علي شيخه ويترحم عليه

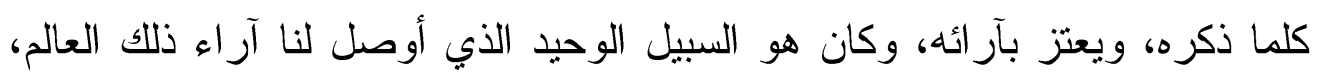

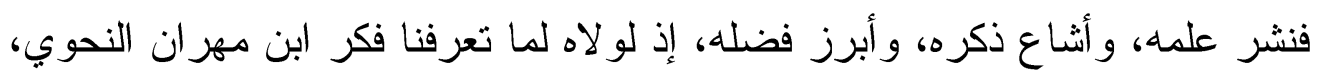
وقد أحصيث ترحمّ ابن الخباز على شيخه ابن مهران في مصنفاته التي وصلتنا، فوجدثه قد ترحم عليه أكثر من ثمانين مرة. 


\section{المبحث الأول: السؤالات النحوية وجواباتها

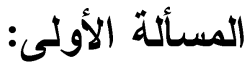

دلالة (قد) على التكثير عند دخولها على الفعل المضارع:

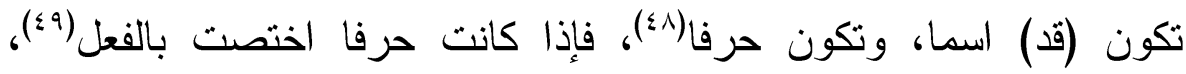

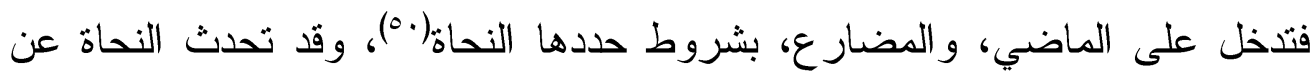
دلالتها عن دخولها عليهما، وما يعنينا في هذه المسألة دلالتها عند دخولها على الفعل ولى ولى

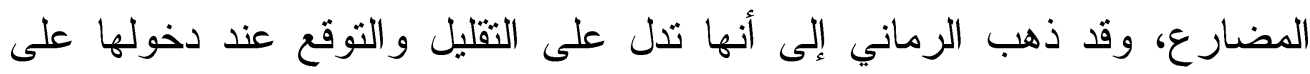
الفعل المستقبل(1)، ويبدو أن ابن الخباز ممن يميل إلى هذا الرئي أبي، إذ ذكر أن "هن

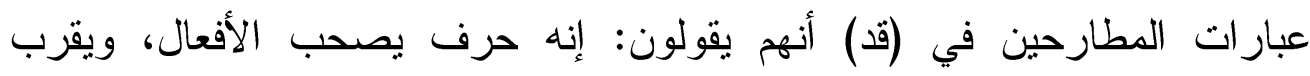

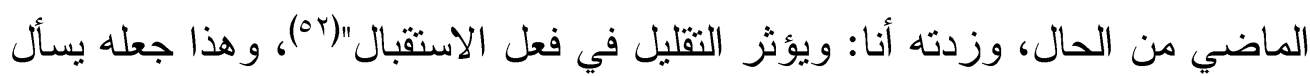
عما ذهب إليه شيخه من دلالتها على التكثير، فقال: "ور أيت الثيخ يقول في قول ذي وني الرمّة:

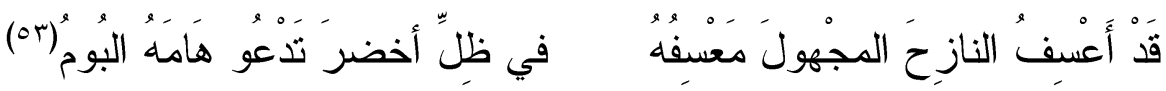
إن (قد) للتكثير، فسألتُه عن ذلك فقال: لأنَّ هذا مُتمدِّه، وهو لا ينمدَّح

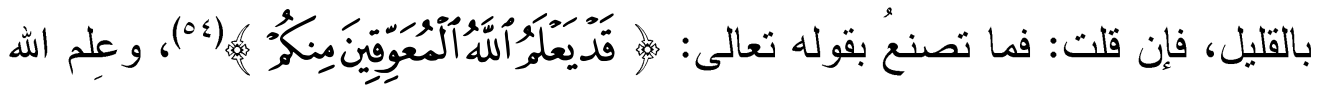

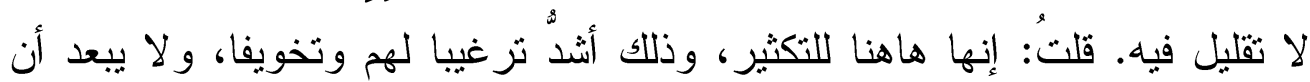

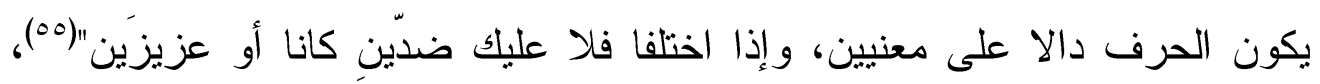

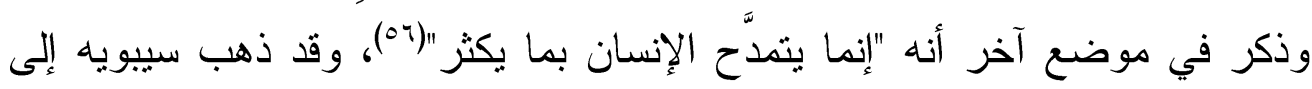

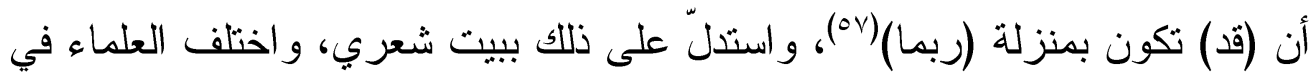
تأويل ما ذهب إليه سيبويه، فعلى سبيل المثال نجد الزمخشري يرى تارة أنها بمنزلة

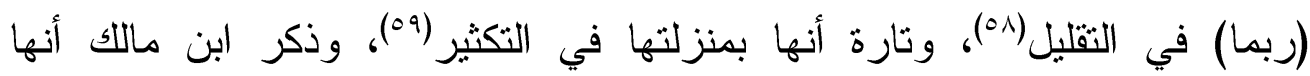

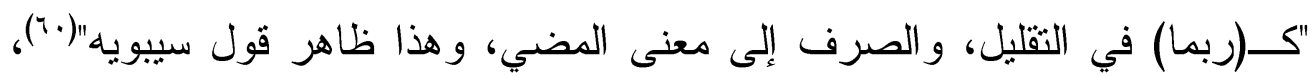
بينما ذهب أبو حيان إلى أن (ق) بمنزلة (ربما) في التكثير ("י). 
وعند مراجعة ما ذكره النحاة في معاني (قد) عند دخولها على الفعل المضار ع، وجدنا لديهم آراء متفرقة على النحو الآتي:

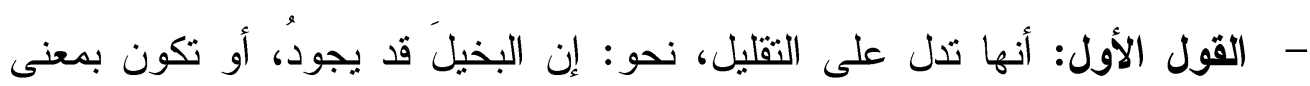

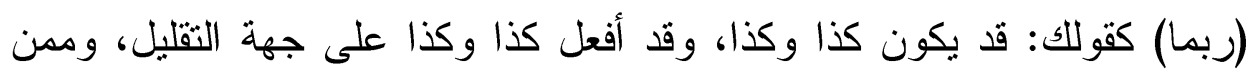

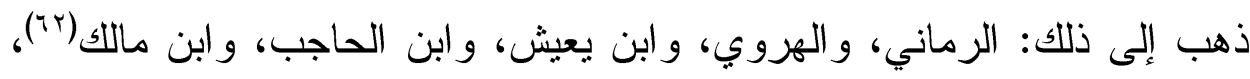

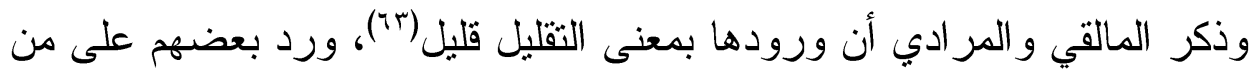
ذهب إلى ذلك المعنى، فذكر أنه لو قيل: البخيل يجودُ، فهم منه الثقليل؛ فالثقليل

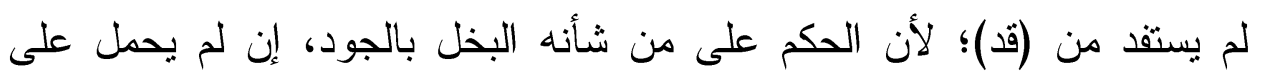

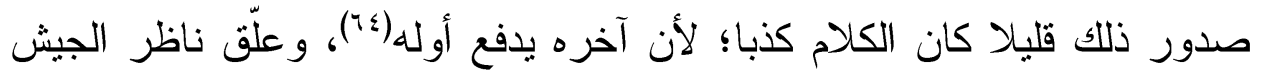

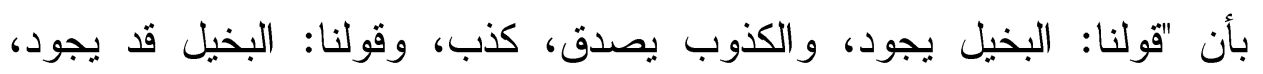

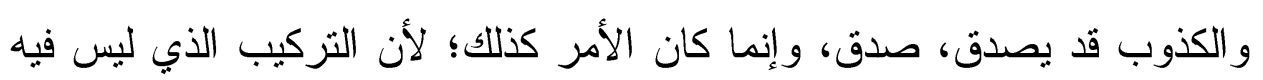

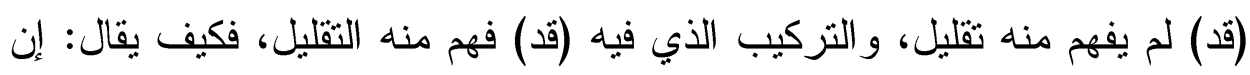

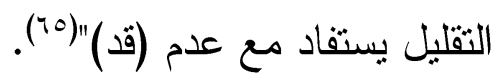

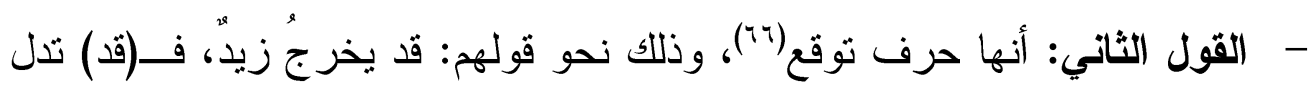

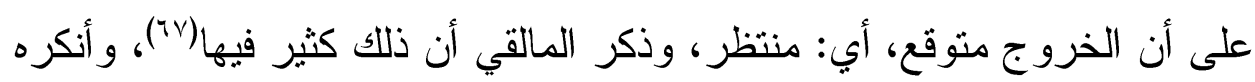

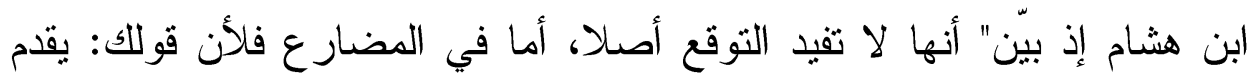

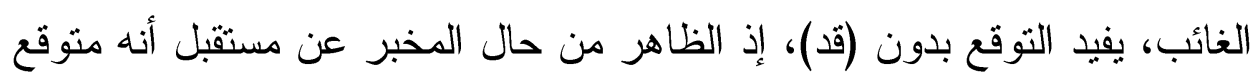

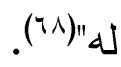

- القول الثالث: أنها تدل على التكثير (19)، وعلّق أبو حيان على ذلك بأن "من زعم

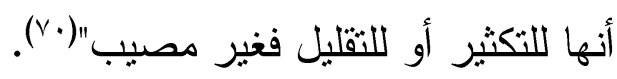

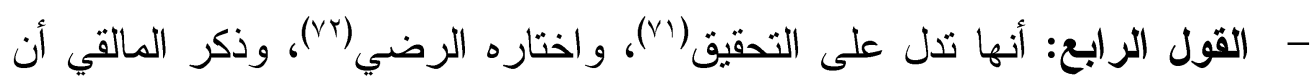

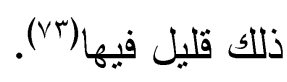


- القول الخامس: أنها تقيد الاحتمال أو الثٔك، إذ ذكر الرماني أنها "قد تستعمل في

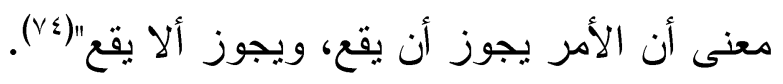

ووفقا لما تقدم عرضه من أقوال النحاة، يمكننا القول إن (قد) نأتي للالالة

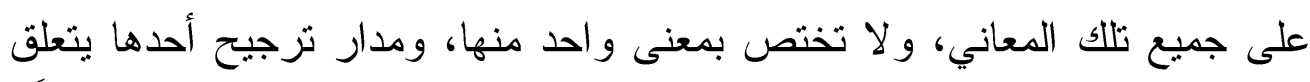

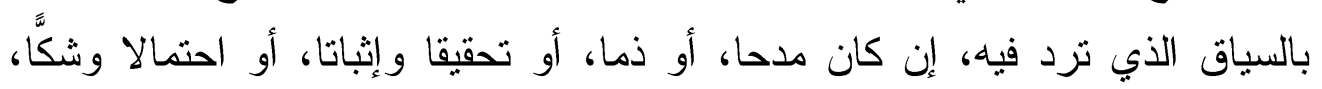

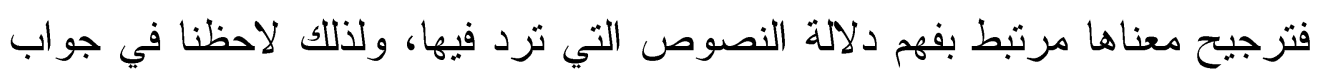

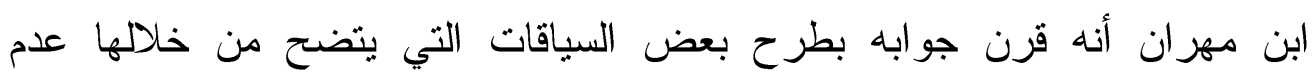

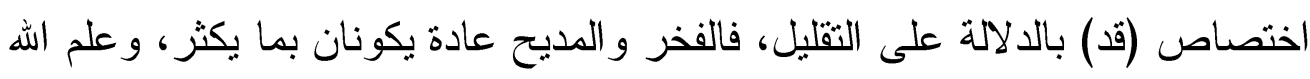

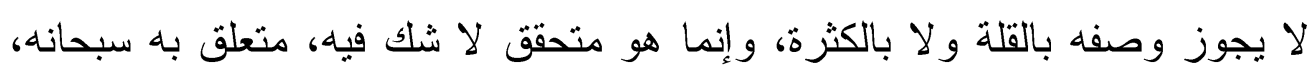

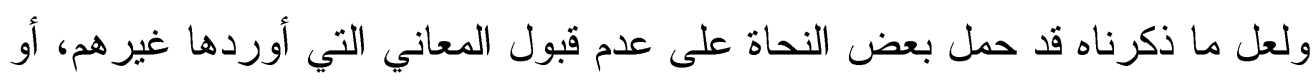

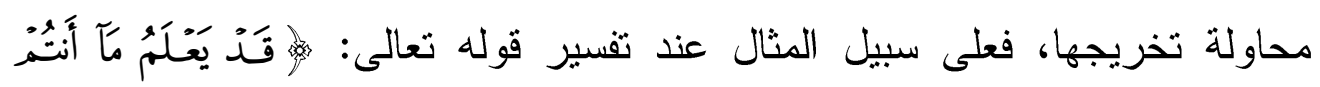

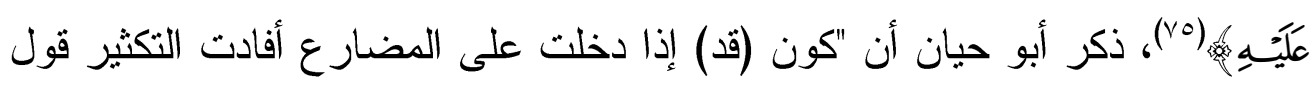

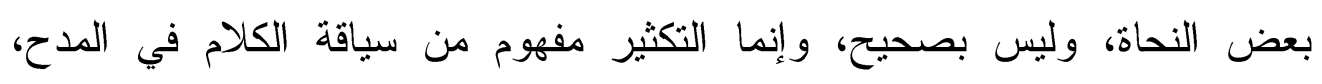

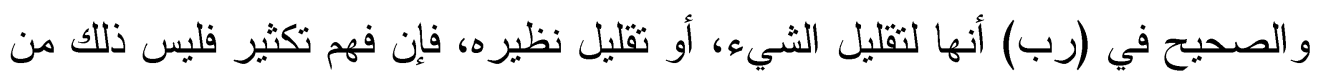

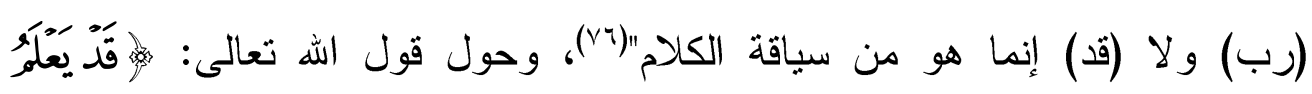

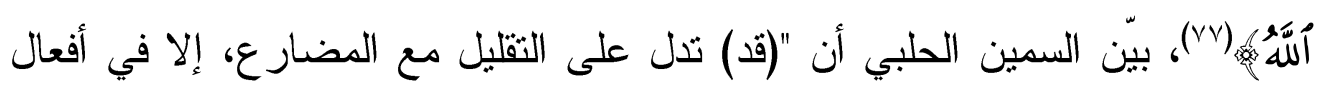

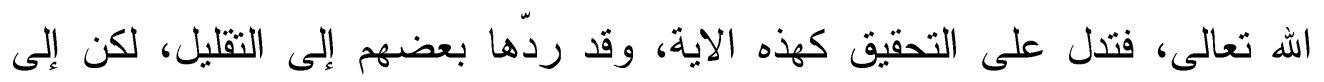

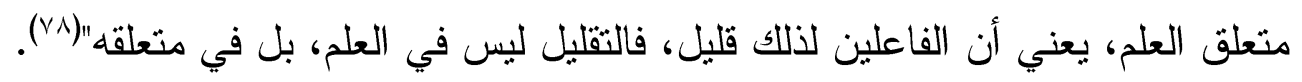

المسألة الثانية:

علة كون الأمر يجيء بالحرف وبالصيغة، وكون النهي لا يرد إلا بالحرف:

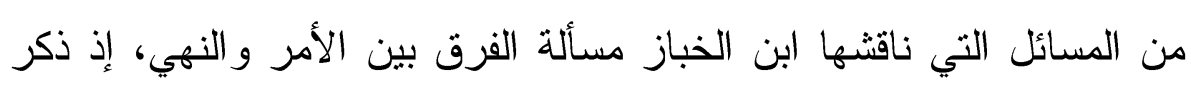

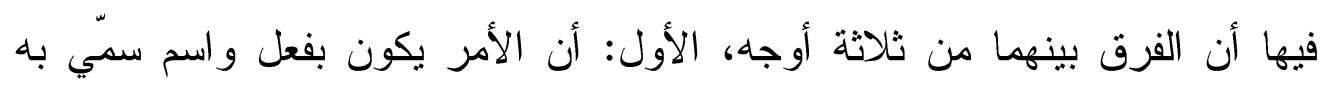




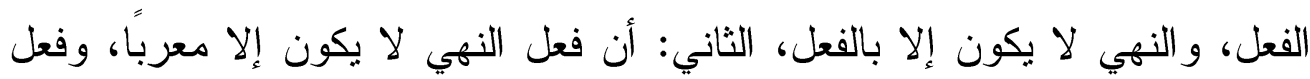

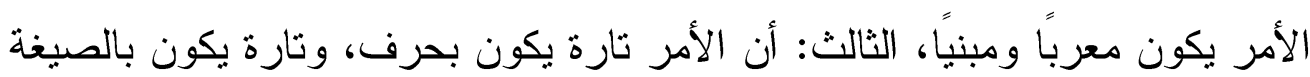

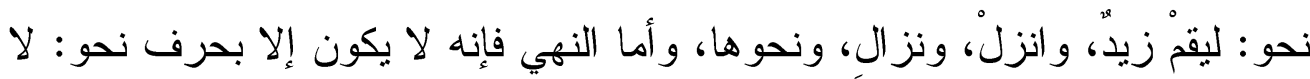

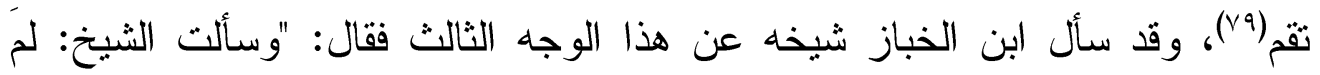

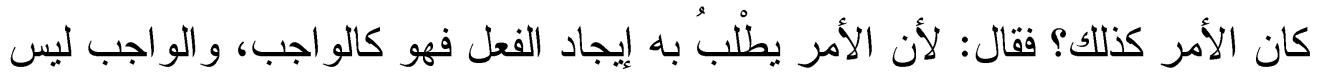
له حرف، نحو: قام زيدُ، و النهي بُطلَبُ به رفع الفعل ونركه، فهو كالنفي، و النفي

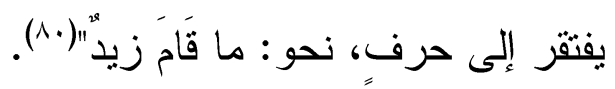

وعند مر اجعة ما ذكره النحاة حول حكم وجوب كل من الأمر و النهي، نجد

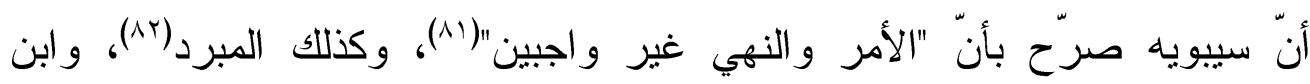
السر اج(ז^)، ونوقف ابن فارس في بيان حكم كل منهما، إذ ذكر أنه: "إن قال قائل:

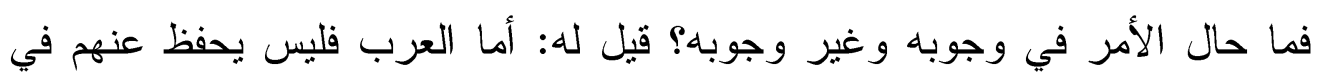
ذلك شيء، غير أن العادة بأن من أمر خادمه بسقيه ماء فلم يفعل أن خادمه عاصٍ،

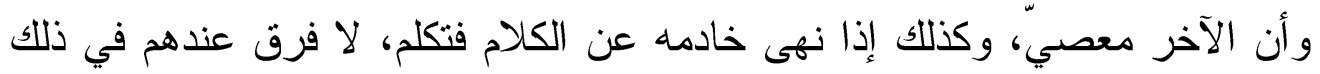

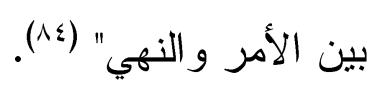

و ابن مهران في جوابه المتقدم جعل الأمر كالواجب، لأنه بطلب به إيجاد الفعل، فأشبه الواجب في كونه يطلب به وقوع الفعل، فهو كالمتحقق، وفي كونه يمكن وروده دون حرف، بخلاف النهي الذي يطلب به نرك الفعل، ويشبه في ذلك النفي الذي ينفي حدوث الفعل، وكل منهما يفتقر إلى الحرف، ولم أقف على من تحدث عن هذا المسلك الدقيق غير ابن مهران. المسألة الثالثة:

\section{إضافة لفظ (فوه) وفيه الميم:}

من الأسماء الستة (فو)، وهو "يستعمل على ضربين: إما بالواو أو بالميم،

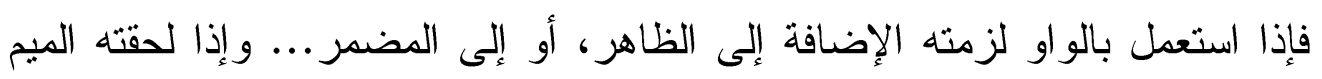




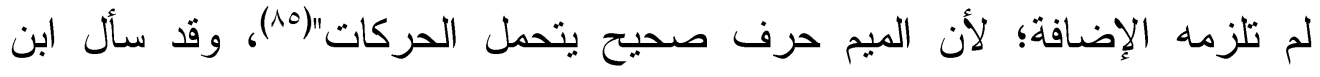

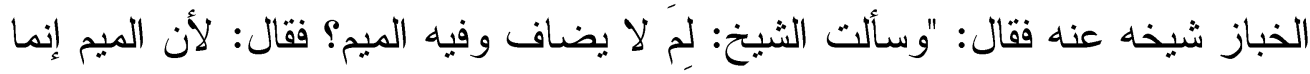

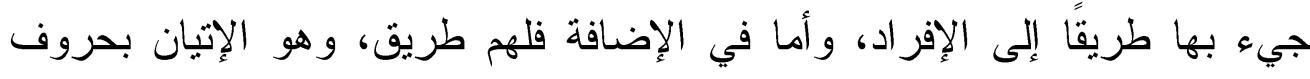

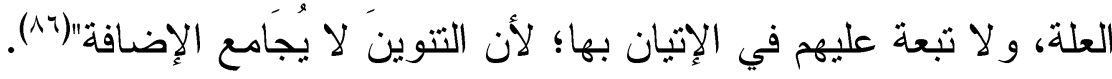
و وعند مر اجعة ما ذكره النحاة حولها وجدناهم فريقين:

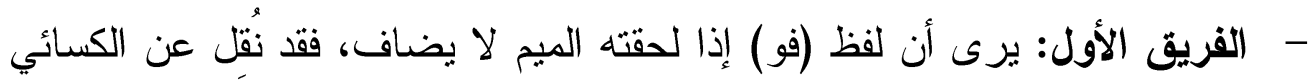

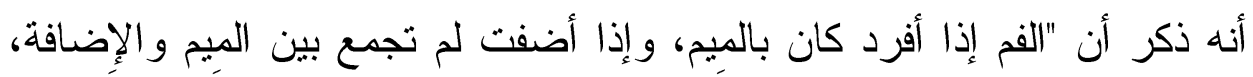

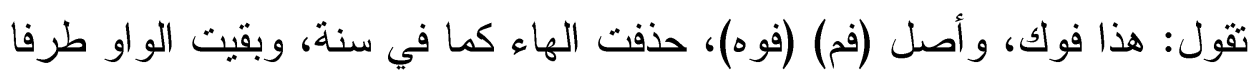

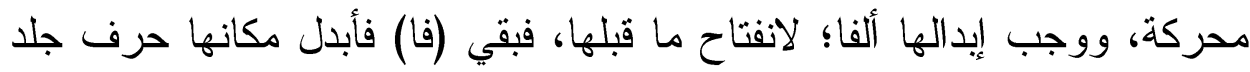

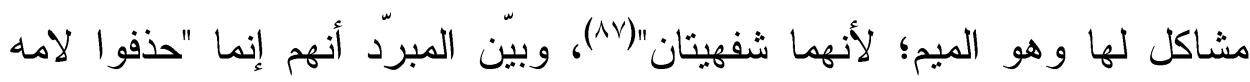

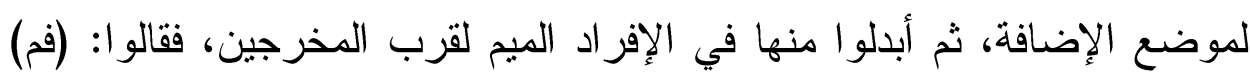

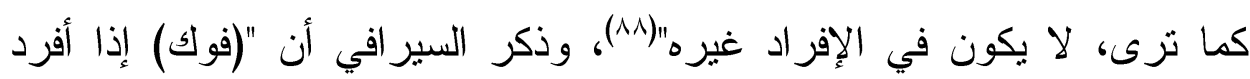

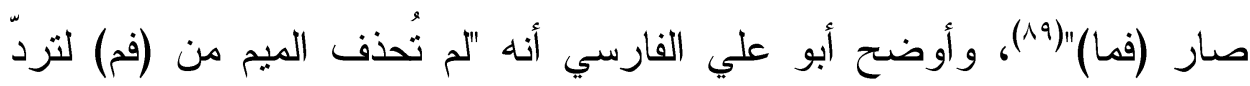

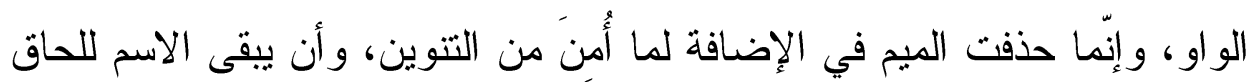

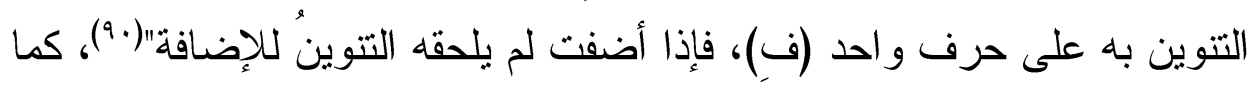

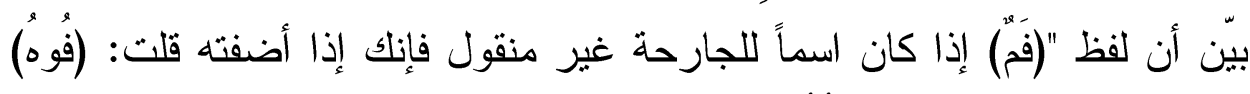

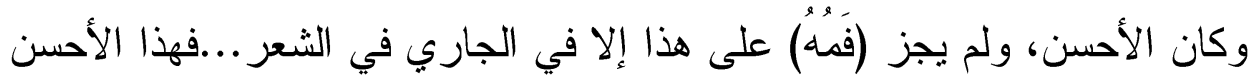

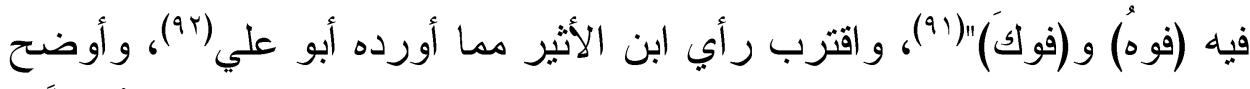

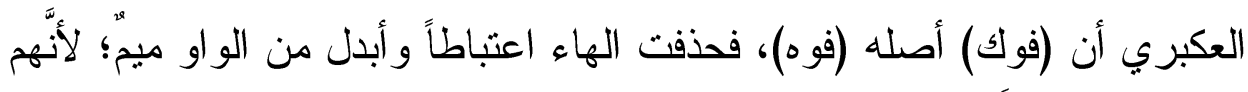

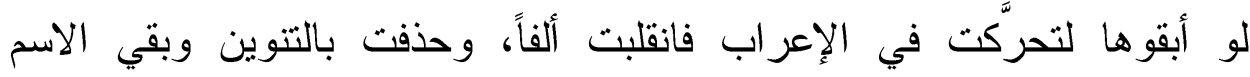

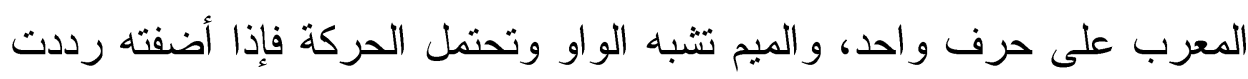
الو او (ar).

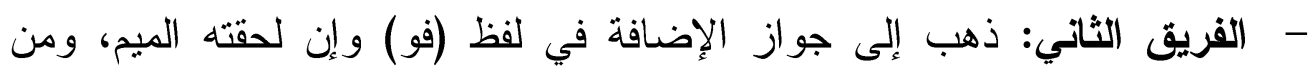

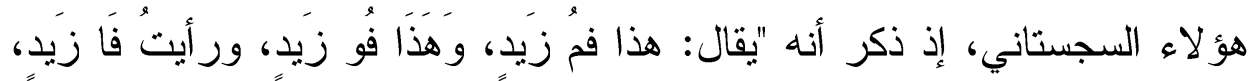




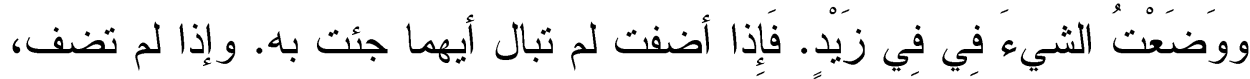

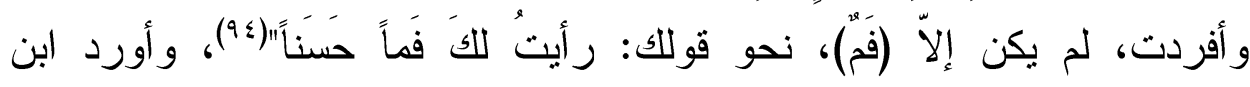

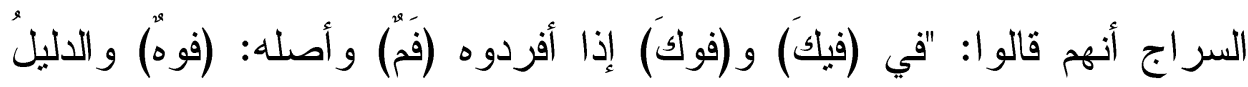

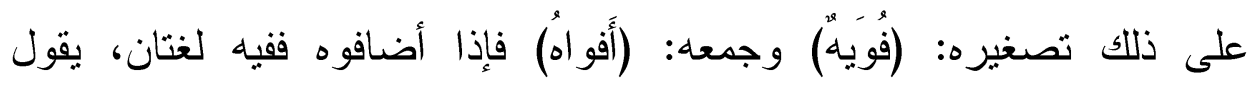
بعضهم: هذَا فُوكَ، ورأيتُ فالك، وفي فيكَ، فيجيئون بموضع العين ويحذفون

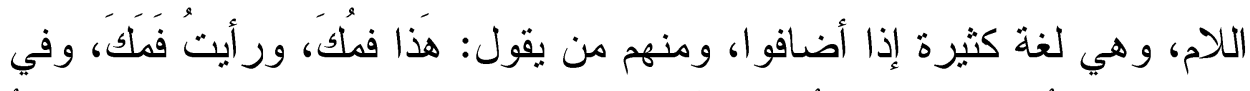

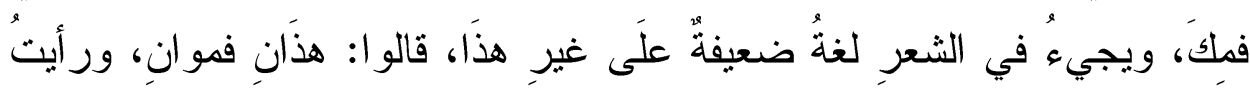

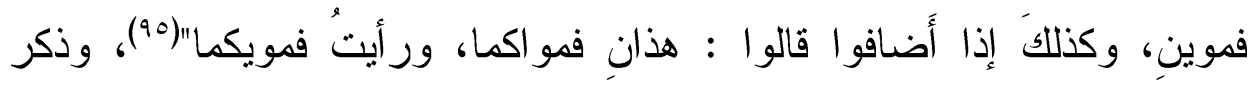

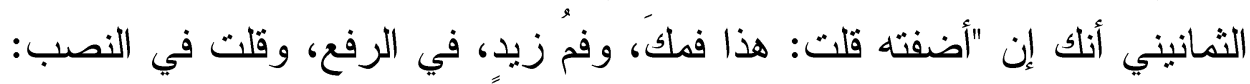

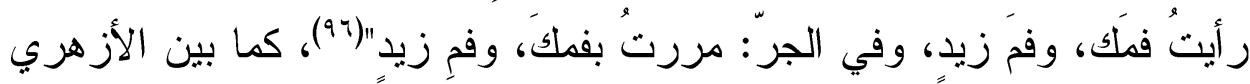

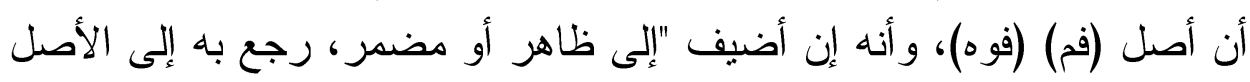

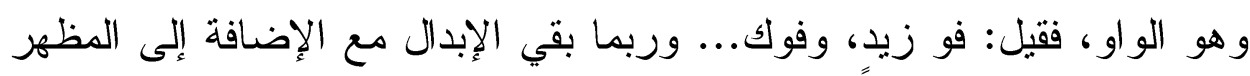

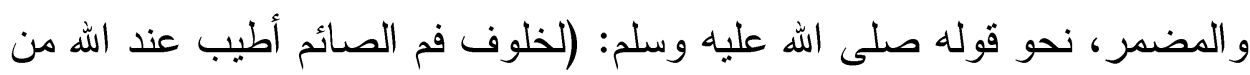

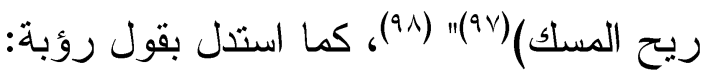

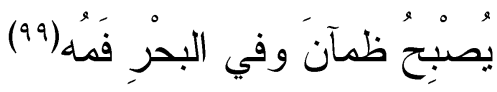

والأي يترجح: رأي الفريق الثاني، الذي أجاز الوجهين: رد لفظ (فم) عند الإضافة إلى أصله الواو، أو إبقاء الإبدال مع إضافته إلى المضمر أو المظهر؛ لورود ذلك في فصيح الكلام، ومنه الحديث المتقدم، وبيت رؤبة.

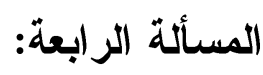
علة كون حرف الإعراب واواً قبلها ضمة في قولهم: جاعني أبوك: اختلفت آراء النحاة حول إعراب الأسماء الستة، وتتوعت مذاهبهم في ذلك،

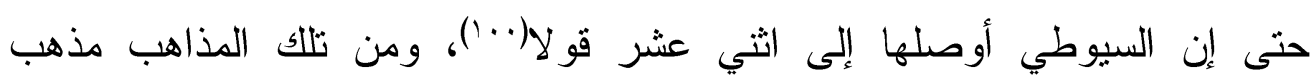
سيبويه، وقد فسّر ابن الخباز أصل الأسماء الستة وفق ما ذكره سيبويه، ثم أتبع ذلك 
بسؤال شيخه عنه فقال: "فإن قلت: فكيف كان أصلها على قول سيويه؟ قلت: أما

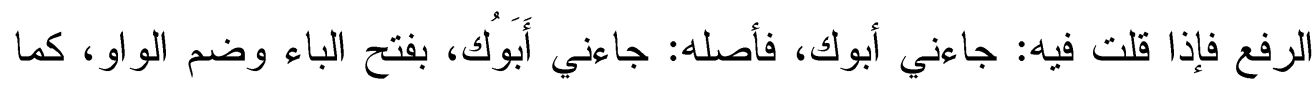

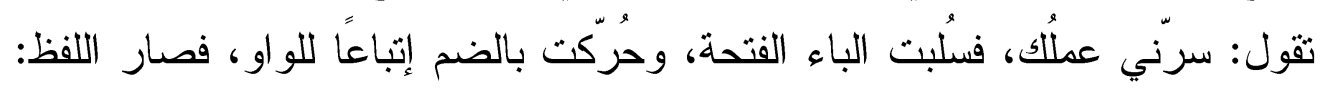

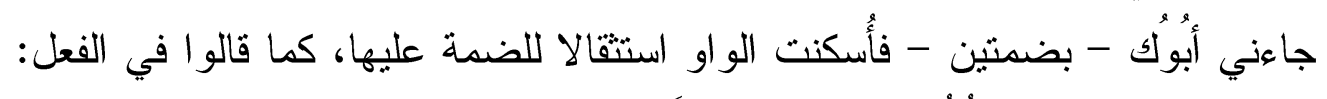

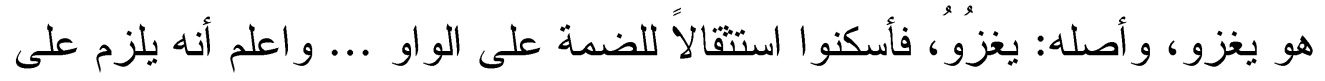

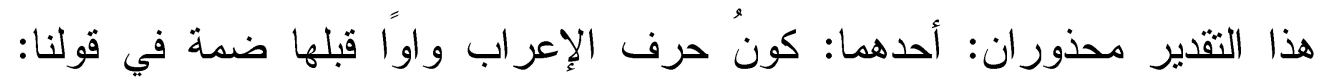

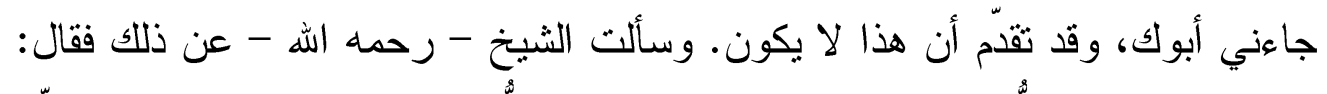

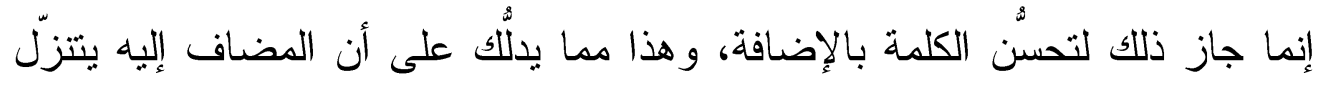

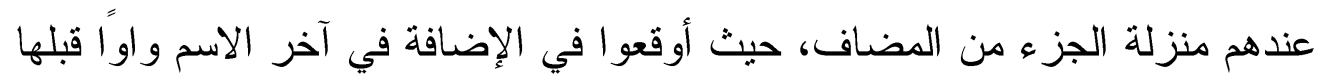

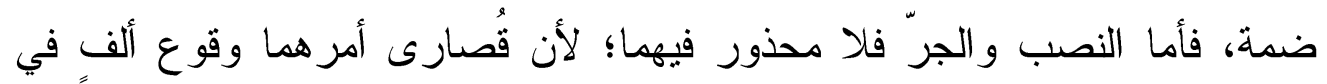

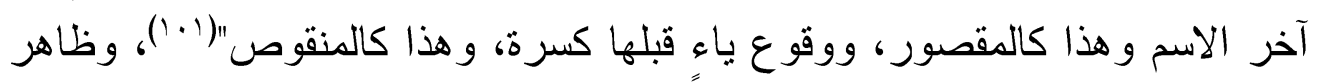

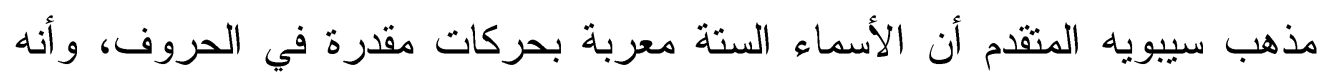

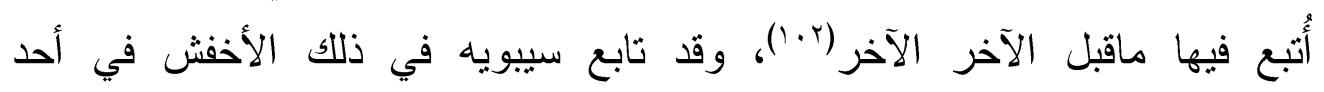

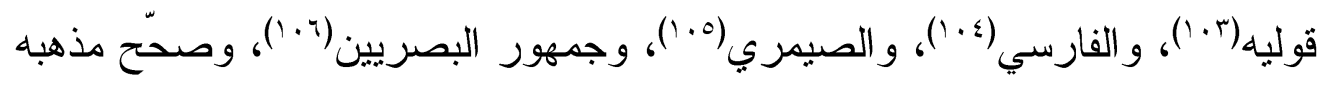

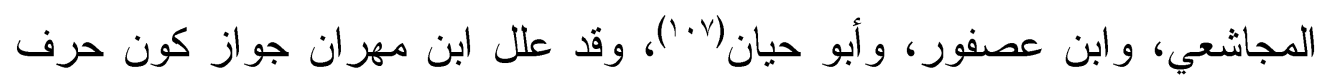

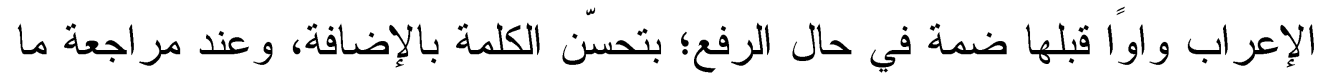

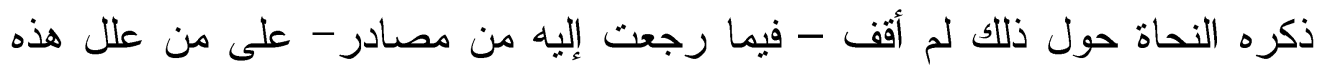

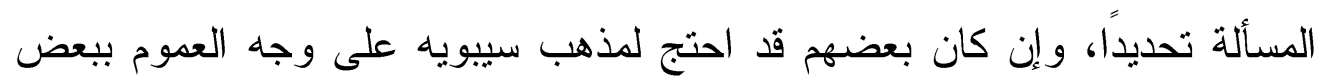
العلل، ومن أولئك الثمانيني الذي ذكر بعر عددا من العلل منها: - - أن إتباع حرف العلة ما قبله أسهل و ألذ في السمع.

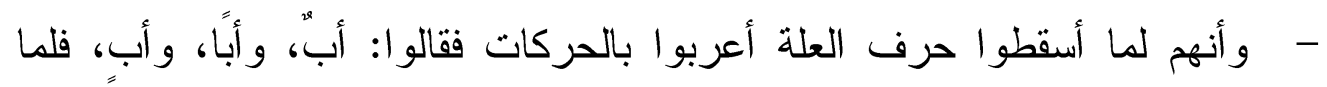

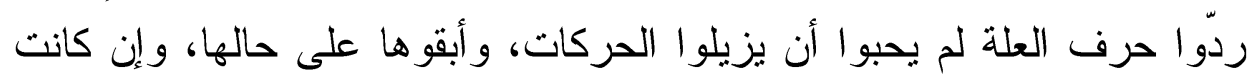

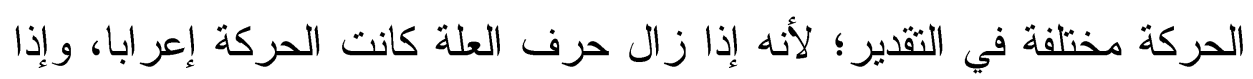
عاد حرف العلة صارت الحركة إتباعا. 
- - وأنهم قد جعلوا في بعض الأسماء الصحيحة ما قبل حرف الإعراب تابعا في

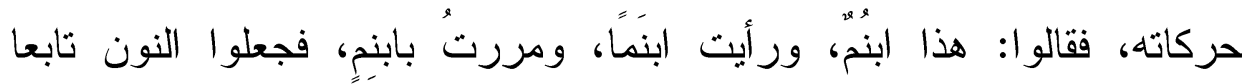

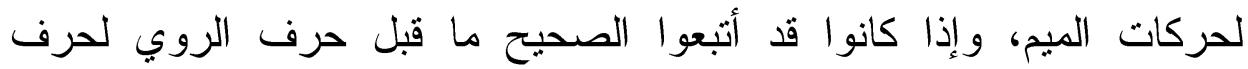
الروي، وهم لا بستقفيدون بهذا الإتباع خفة، فإتباعهم في المعتل أولى، لأنهم

يستقيدون به خفّة.

- - موأن الحركة التي تكون في المفرد إعرابًا له هي بعينها تكون إعرابًا له إذا

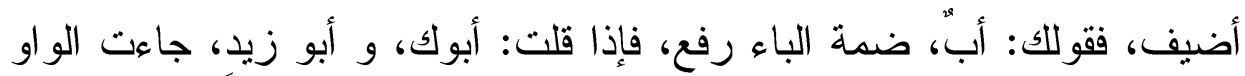

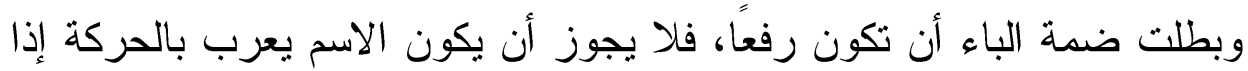

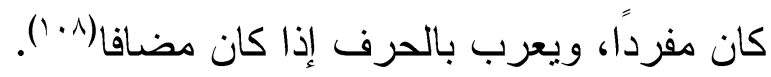

وذكر ابن الخشاب أنك إذا قلت في الرفع: جاءني أبوك وأخوك، فالأصل: جاءني أبوَكُ وأخَوْك، ثُ سلبوا الحرف الذي قبل الواو التي هي حرف الإعراب حركته، فسكن، وضموه إتباعا لحركة الواو، ثم حذفت حركة الإعراب استتقالا لها على الو او، لتؤول الحال بهم إلى الصورة التي أر ادوها من التوطئة للنثية و الجمع، فصارت الكلمة في الرفع على هذا النحو (9.9.

و اقترب العكبري مما أورده الثمانيني إذ بيّن أن المعتل مقيس على الصحيح،

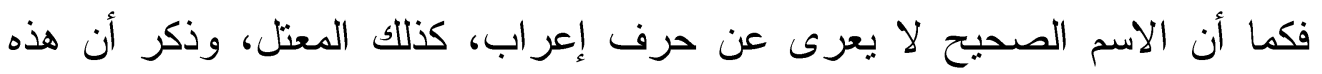

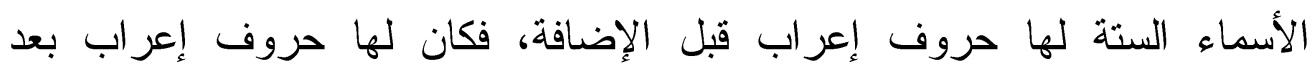
الإضافة كسائر الأسماء، فهي تعرب بالحركات قياسًا على الإفراد، و الإعراب فيها

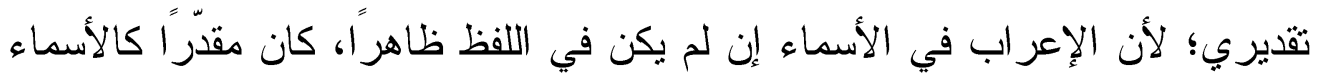

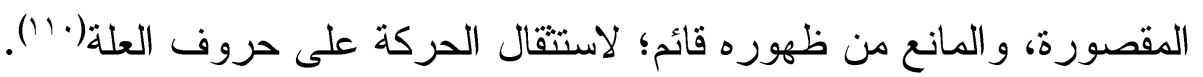
و هذه المسألة تعد من أدق المسائل التي تلمّّ ابن الخباز جو ابها من شيخه، ولم أقف على من تحدّث عنها على وجه الخصوص، إذ حاول استكثاف علة جواز ما كان محظورا عند النحاة في غير هذا الموضـ. 


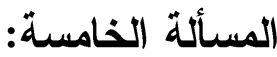

\section{اسمية (أل) الموصولة: المبه:}

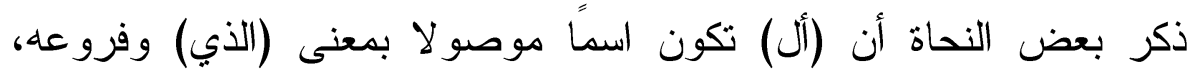

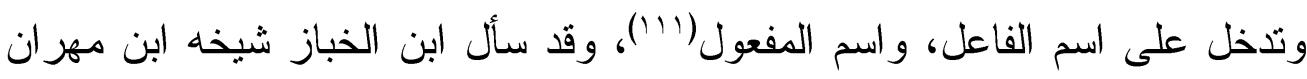

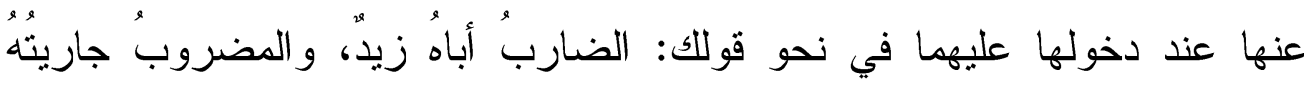

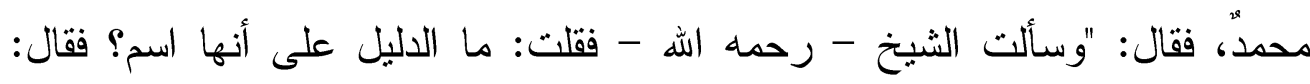

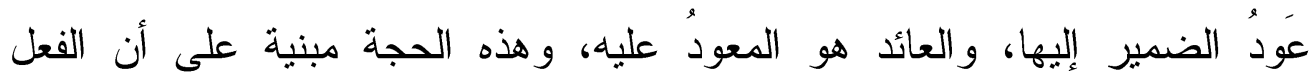

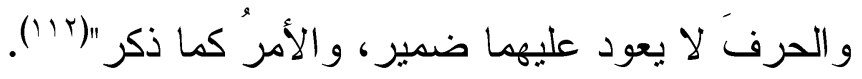

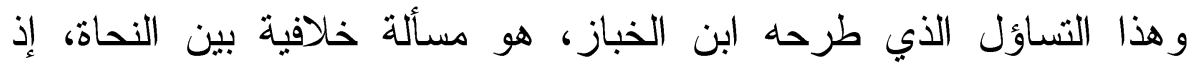
اختلفوا في (أل) هذه إلى عدة أقوال، واستدلوا عليها بعدد من الأدلة على النحو النى الآتي:

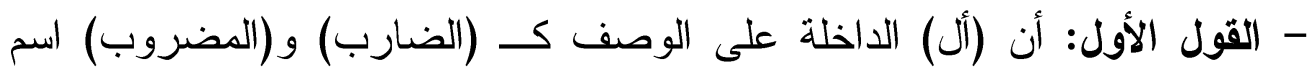

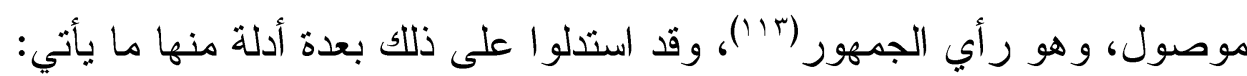

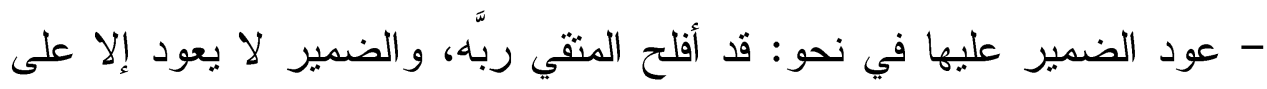

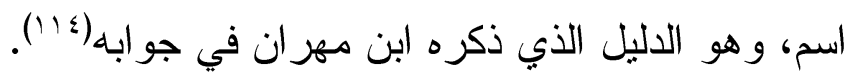

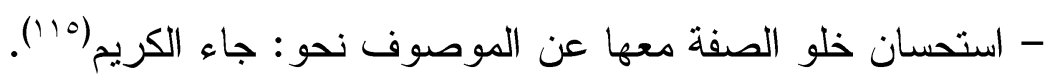
- إعمال اسم الفاعل معها بمعنى المضي (1/1').

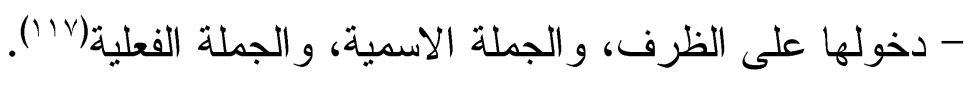

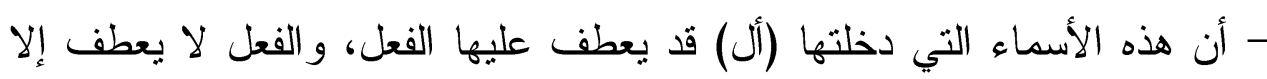

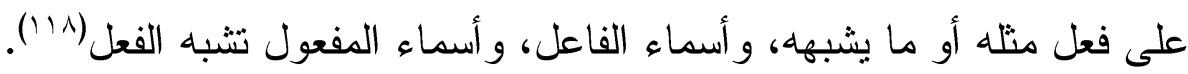

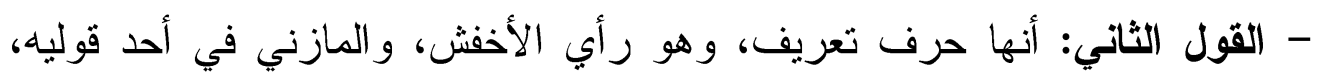

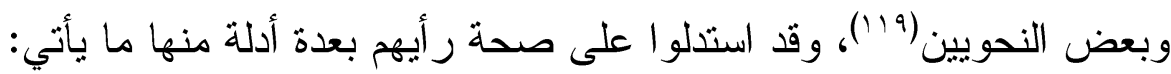

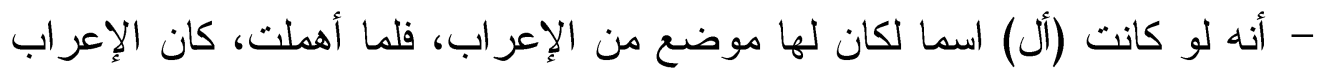

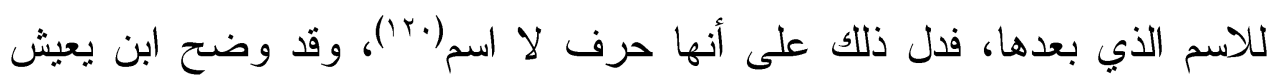


هذه الحجة بأنها "لو كان لها موضع من الإعر اب لكنت إذا قلت: جاءني الضارب، يكون موضعها رفعاً بأنها فاعل، فكان يؤدي إلى أن يكون للفعل الواحد فاعلان

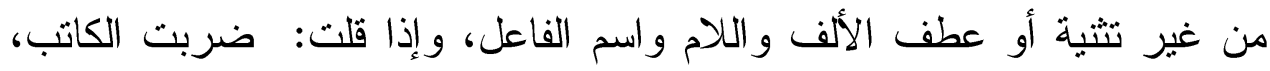
يكون للفعل مفعو لان وذلك لا يجوز؛ لأن هذا الفعل لا يكون له أكثر من مفعول واحد، وإذا قلت: مررت بالضارب، يكون لحرف الجر مجروران وذللك

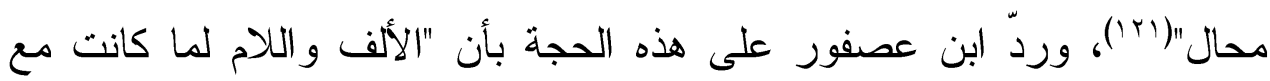

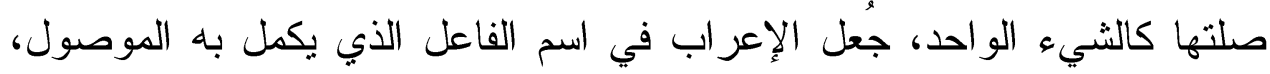
وساغ ذلك فيها ولم يسغ في (الذي) وأخواته، لكون الصلة فيها اسمًا مفردًا،

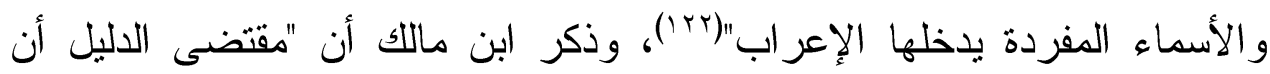

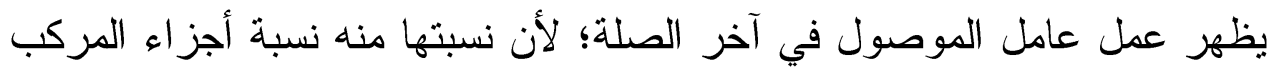
منه، لكن منع من ذلك كون الصلة جملة، والجمل لا تتأثز بالعوامل، فلما كانت صلة الألف واللام في اللفظ غير جملة، جيء بها على مقتضى الدليل لعدم

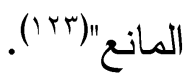

وقد عبر بعض النحاة عن هذه الحجة بتخطي العامل لها في نحو: جاء الضارب، كما يتخطاها مع الجامد، نحو : جاء الرجل، وهي مع الجامد معرفة، فتكون

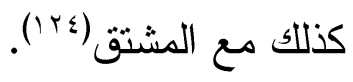
- أن الضمبر لا يعود على (أل) كما ذكر النحاة، بل بعود على موصوف محذوف،

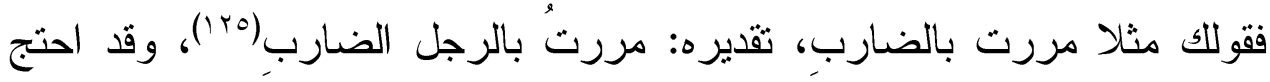

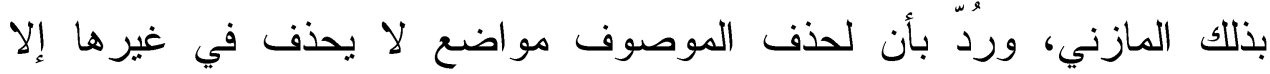
لضرورة، وليس هذا منها(بr(1)، كما ضعَف ابن مالك هذا الدليل لوجهين، الأول:

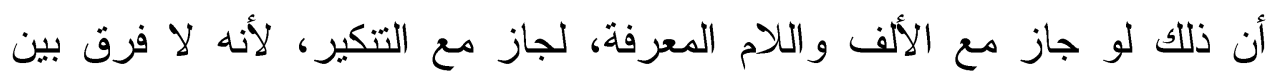
تقدير الموصوف منكرا، وتقديره معرفا، بل كان ذلك مع التتكير أولى؛ لأن حذف هـ المنكر أكثر من حذف المعرف، و الثاني: أن (أل) لو كانت للتعريف، لكان لحاقها اسم لفاعل قادحا في صحة عمله، مع كونه بمعنى الحال والاستقبال، والأمر 
خلاف ذللك، إذ لحاق الألف واللام به، يوجب صحة عمله، وإن كان ماضي

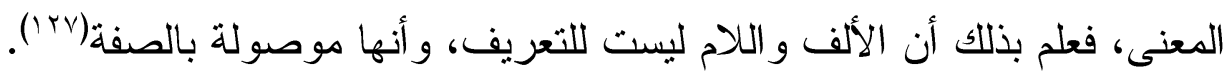

- القول الثالث: أن (أل) اسم موصول، لكن على تقدير كونها منقوصة من (الذي)

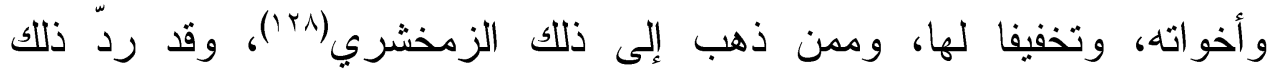

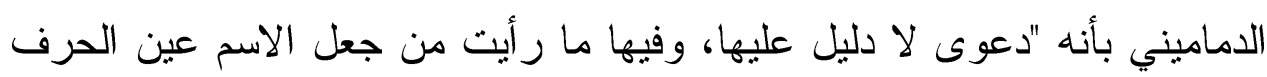

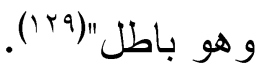

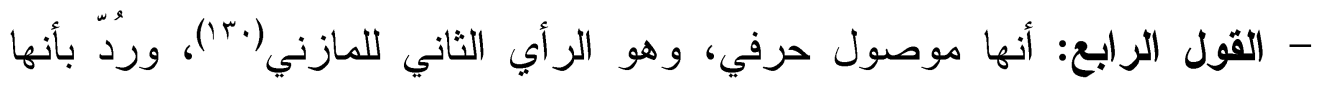

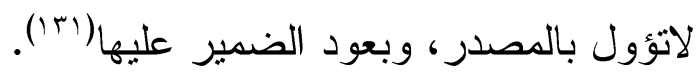

ونقل الدماميني عن الرضي أن هذا الخلاف في (أل) إذا "لم تكن اللام للعهد،

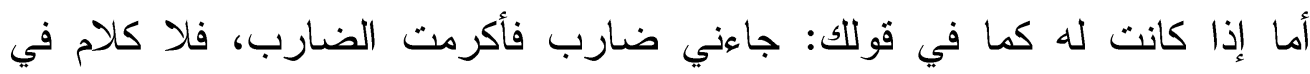

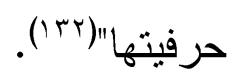

و الذي يترجح مما تقدم هو الرأي الأول، إذ هو رأي جمهور النحاة، ولقوة

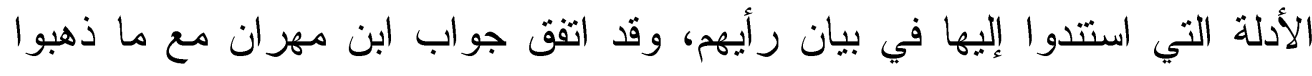

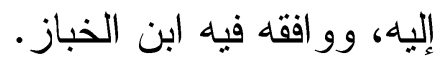

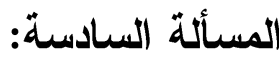

\section{(الفرق بين (عسى زيد" أن يفعل)، و(عسى زيدّ يفعل):}

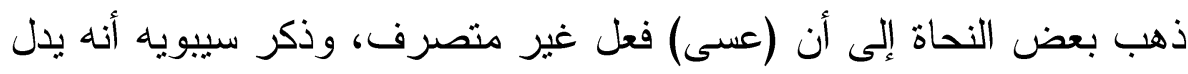

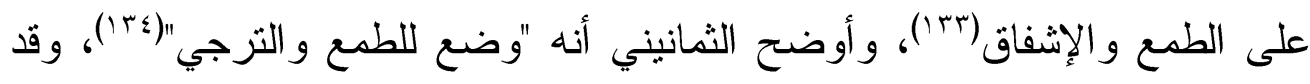

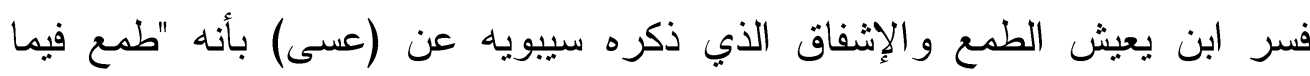

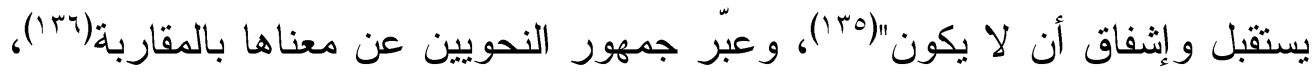

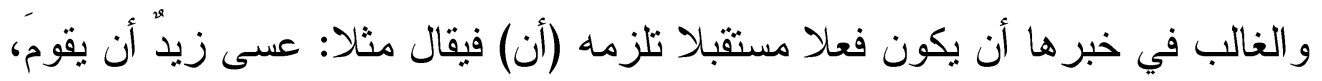

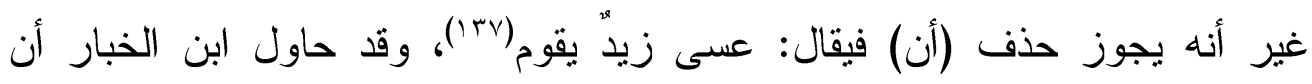

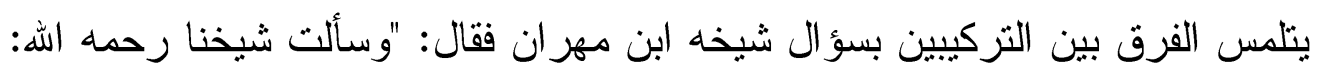

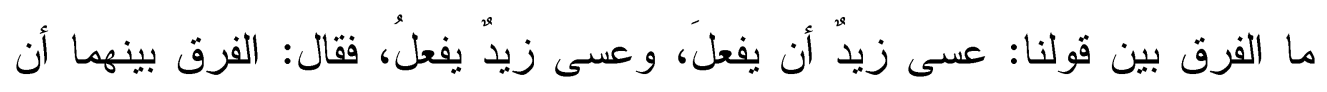


طرح (أن) يؤذن بقوة الطمع؛ لأنه قد زال دليل الاستقبال، ولــ(عسى) مذهب آخر :

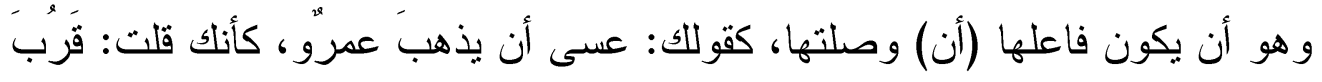

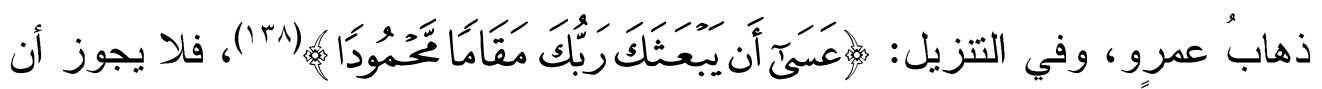
يرتفع (ربك) بــ(عسى)؛ لأن (مقامًا) منصوب بـ (يبعنك)، فلو كان (ربك) مرفوعًا

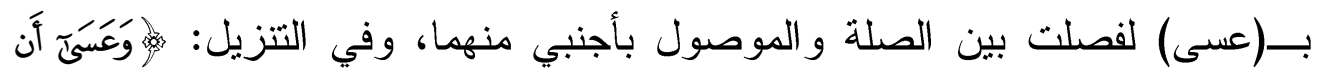

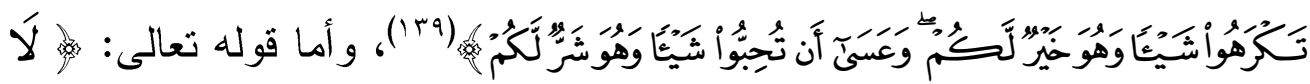

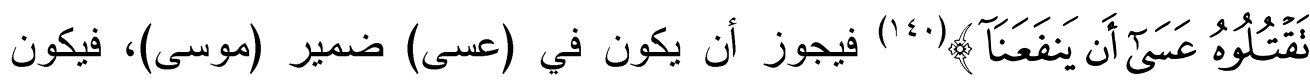

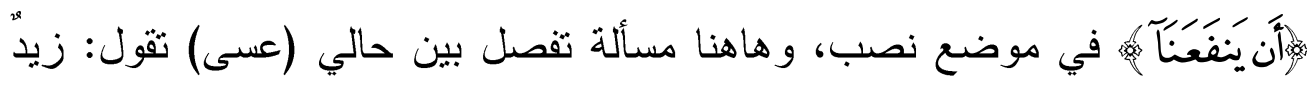

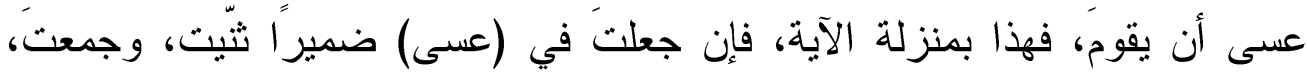

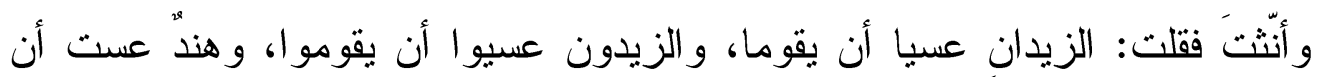

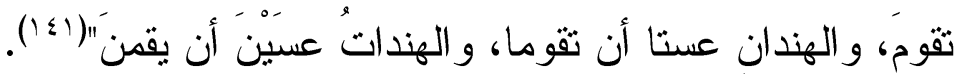
و الذي يظهر في جواب ابن مهران أنه ركّز على بيان الفرق بين النزكيبين من حيث المعنى و الدلالة، ومن حيث الجانب الإعرابي، وعند تتبع ما ذكره النحويون حول (عسى)، نجد أنهم اختلفوا حول حكم اقتران خبرها بــ(أن)، أو تجرده منها، فمنهم من ذهب إلى أن الأغلب اقتران خبرها بــ(أن) و أن تجرده من (أن) ضرورة خاصة بالشعر ، ومنهم من يرى أن ذلك يجوز في الكيلام. فالظاهر من كلام سيبويه جواز حذف (أن) في الكلام حين ذكر أن "من

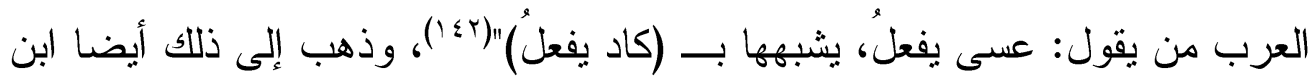

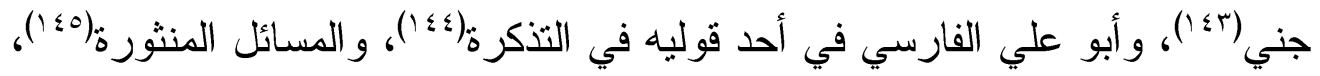

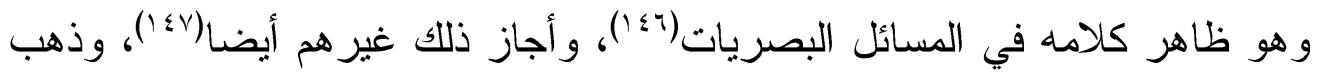
جمهور النحاة إلى أن حذف (أن) من خبر (عسى) خاص بالشعر، وأنه ضرورة

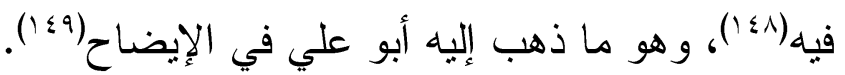


و عند تتبع ما ذكره النحاة في الفرق بين التركيبين، نجد بينهم اختلافا، وقد

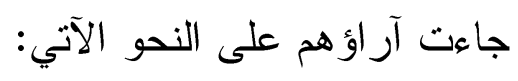

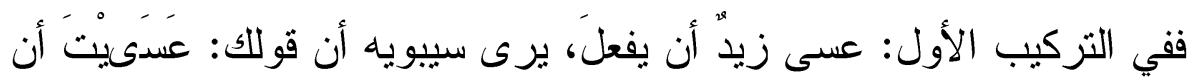

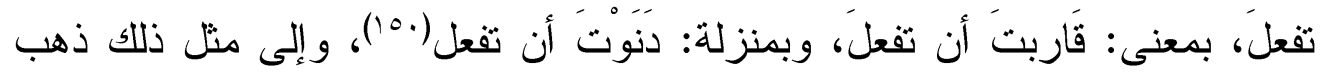

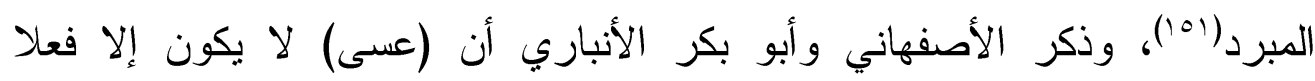

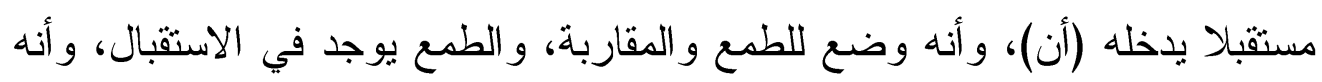

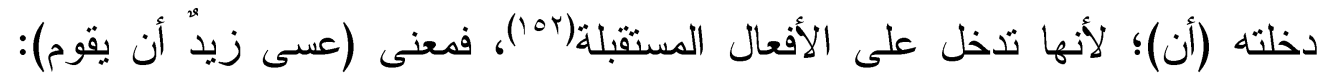

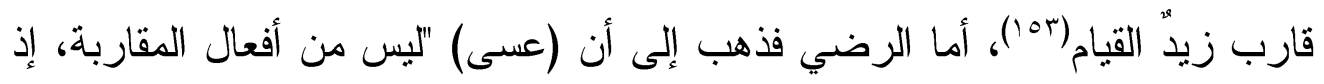

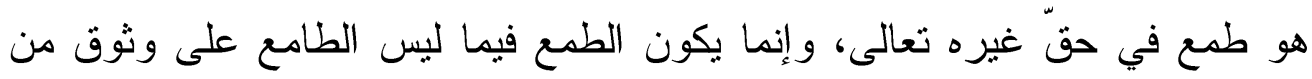

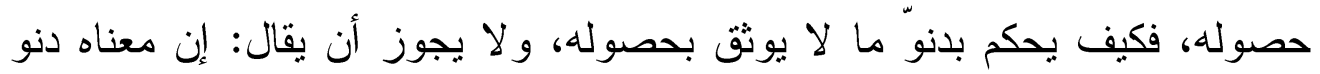

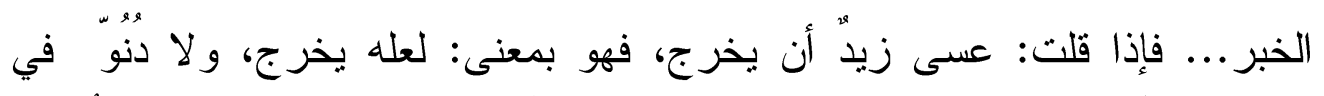

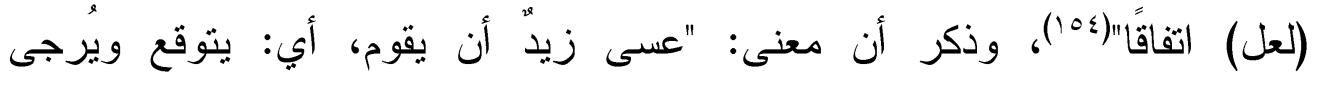

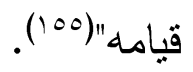

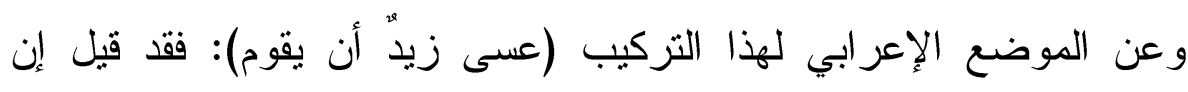

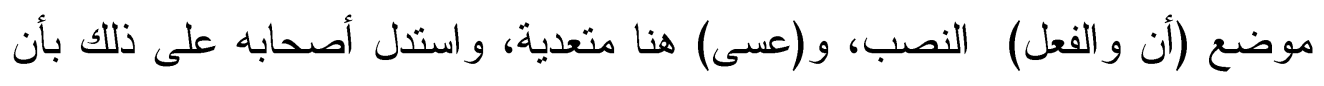

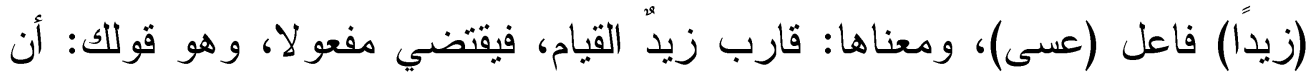

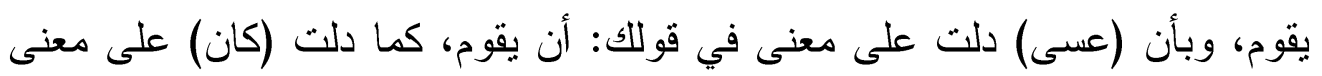

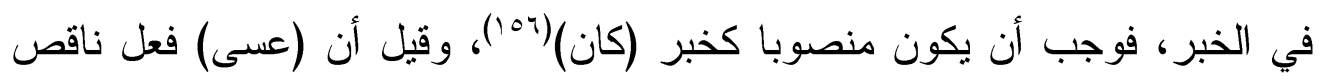

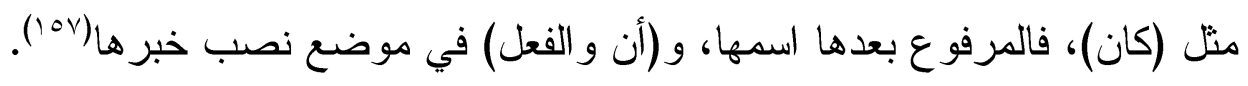

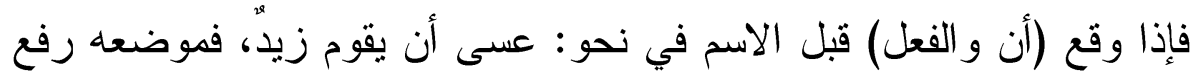

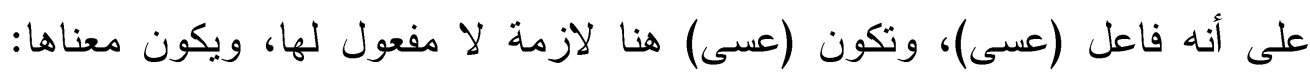

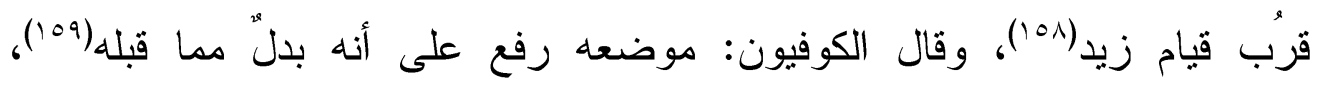

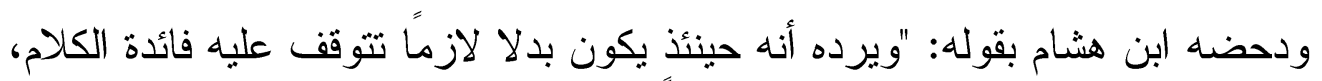

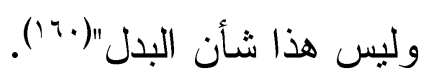


أما التركيب الثاني: عسى زيدّ يقوم، من غير (أن)، فقد ذكر أبو علي أن

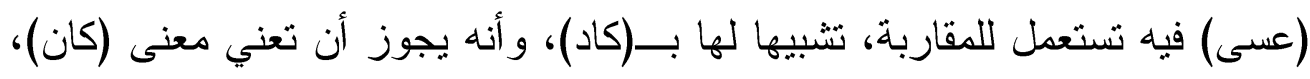

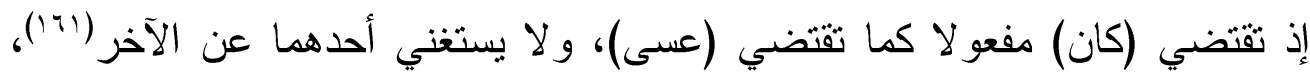
وقريبا من ذلك ذكر ابن يعيش أنه إذا قيل: "عسى زيد يقوم، فكأنه قرب حتى أثنبه قرب كاد، و إذا أدخلوا (أن) في خبر (كاد) فكأنه بعد عن الحال حتى أشببه (عسى)، أنى ومن قال: عسى زيدٌ بفعل، فقد أجرى (عسى) مجرى (كان)، ويجعل الفعل في

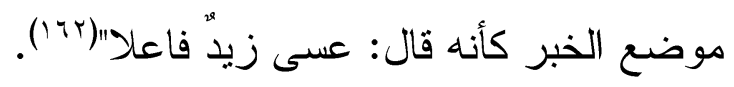

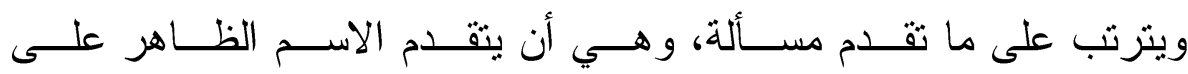

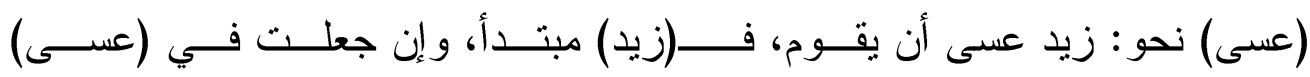

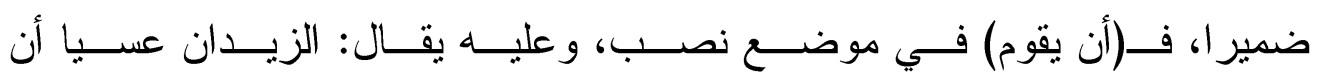

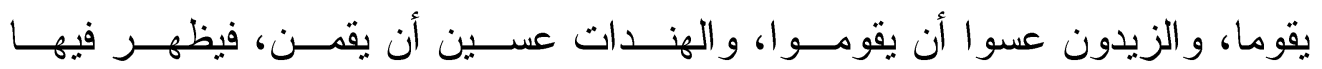

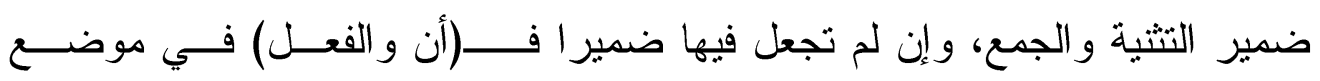

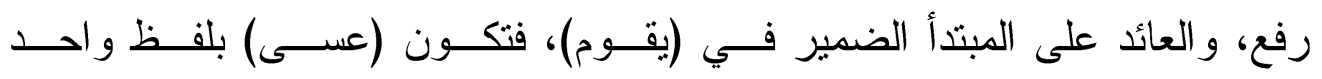

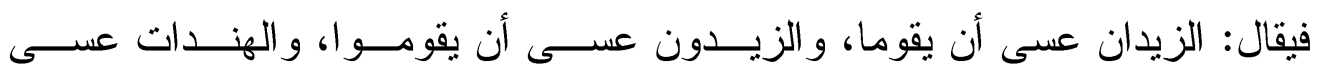

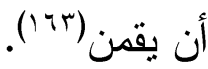

ولعل الراجح والذي يظهر مما تقدم، أن (عسى) إذا لم تظهر معها (أن)

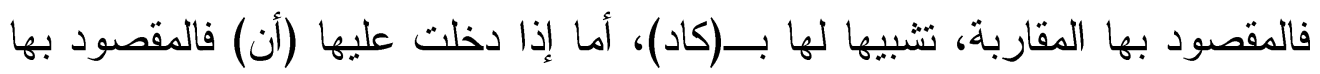
الطمع و الرجاء، ومما بدل على ذلك قول الجرجاني: "خُص (عسى) بــ(أن) الذي هو

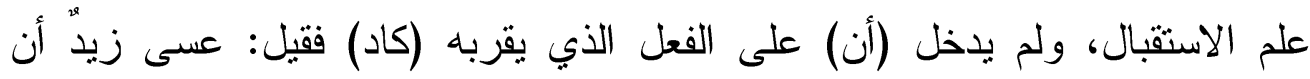

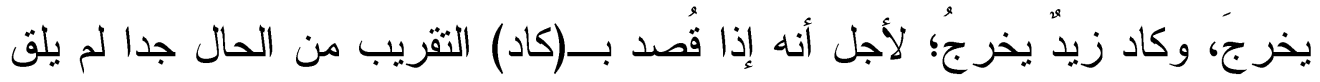

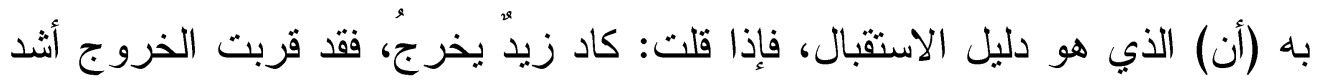
تقريب، ألا ترى أنك لا تقول: كاد زيدُ يخرجُ بعد سنة، وتثول: عسى الله أن بدخلني

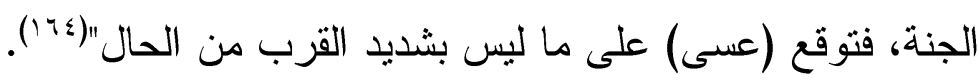




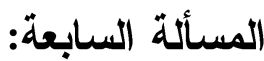

علة تأنيث الفعل مع الفاعل الحقيقي التأنيث، وعدم الاكتفاء بتأنيث الفاعل: إذا كان الفاعل مؤنثا حقيقيا وجب إلحاق الثاء بالفعل الماضي المسند إليه،

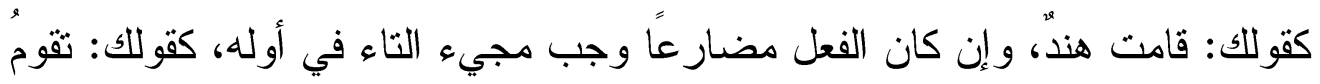

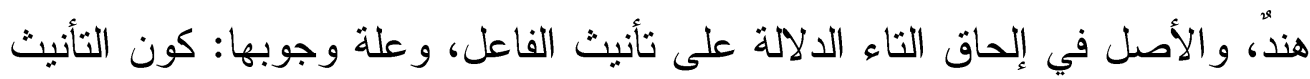

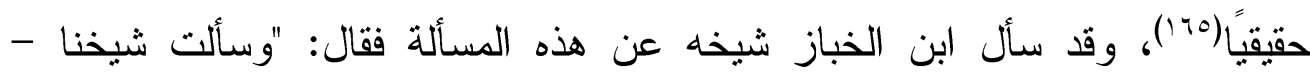

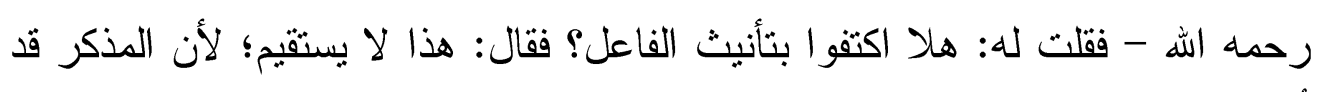

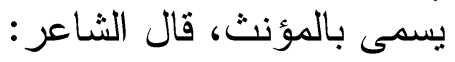

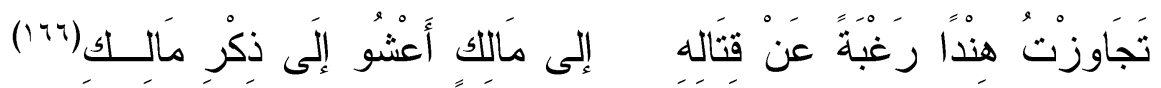

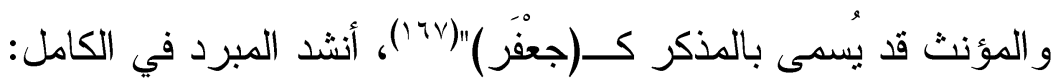

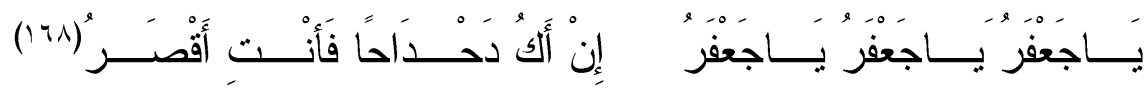
وقال في موضع آخر: " أصل الفعل التذكير، وتذكيره جنسيّ لإفادنه

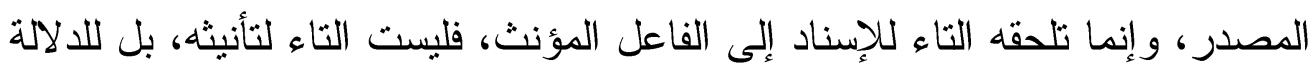

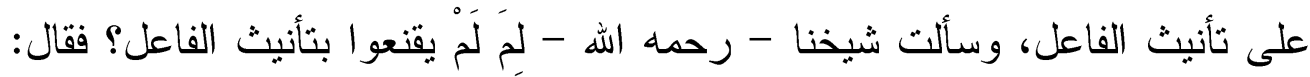

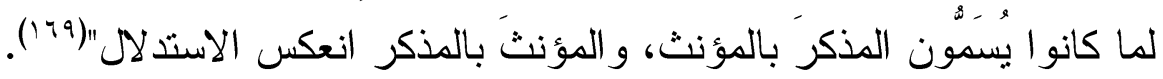
والحديث هنا عن الفاعل الظاهر المفرد حقيقي الثأنيث، غير المفصول عن

$$
\text { فاعله بفاصل، وفي هذه المسألة رأيان: }
$$

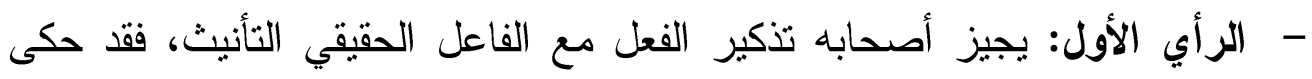

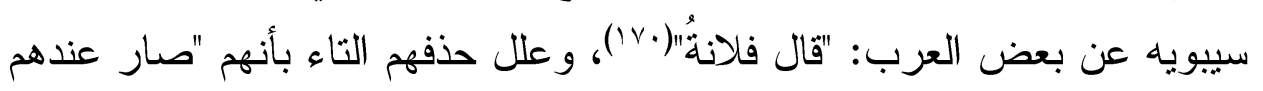

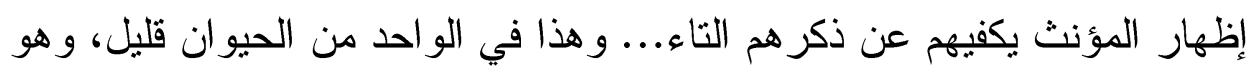

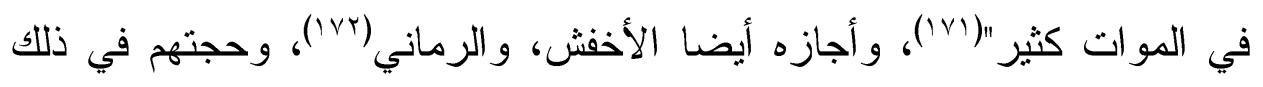

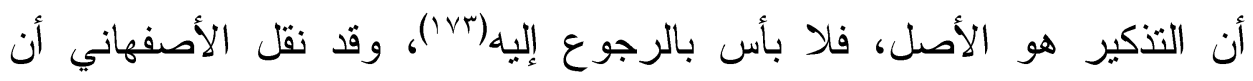

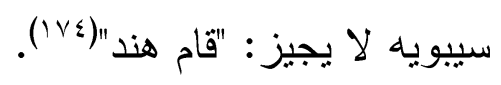

العدد (VV) يناير ا TrV 
ولم يلق هذا الرأي استحسانا من عدد من العلماء، فقد وصفه أبو علي الفارسي بالقبح(1V0)، وذكر ابن هشام أنه "رديء؛ لا ينقاس"(1V7)، ونقل أبو حيان أنه

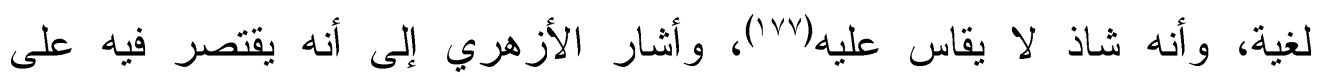

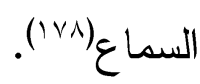

- الرأي الثاني: يرى أصحابه عدم جواز تذكير الفعل مع الفاعل الحقيقي التأنيـــ،

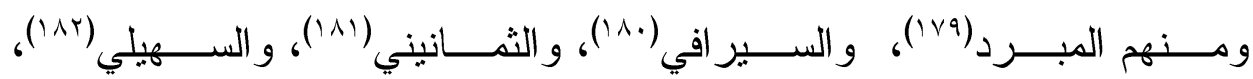

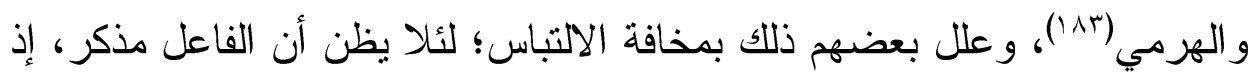
قد يشترك الرجال و النساءُ في أسماء كثثرة، و استدلو ا بما ذكره ابن مهران فــي

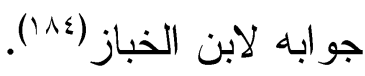

والراجح الرأي الثاني، إذ اللغة العربية قامت على الوضوح و البيان وعدم

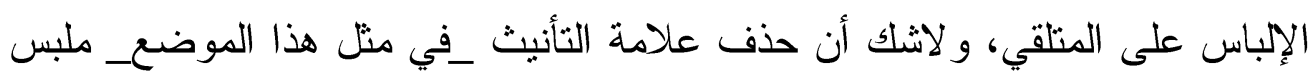

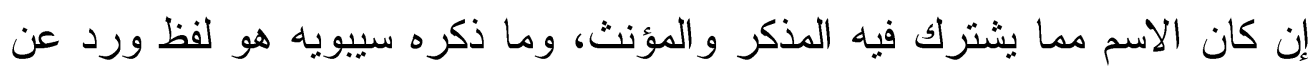
بعض العرب، ونقل لما سمع منهم، وقد ذكر أنه قليل مع وروده، وما نقله عنه ودئ

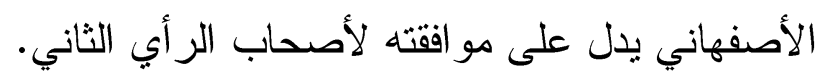

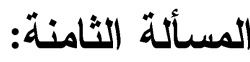

\section{الاستثناء:}

من المسائل التي لم تتضح عند المتقدمين من النحاة مسألة الحديث عن حدّ المّاع

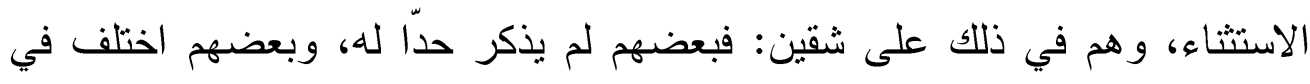

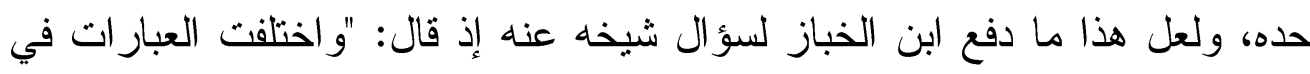
تحديده، وسألت شيخنا - رحمه الله - عن حذّه فقال: هو إخراج الثيء من من حكم غيره بــ(إلإ) أو ما قام مقامها. و هذا الحدّ يشمل المتصل و المنفصل كقوللك: قامو إالا زيدًا، وما فيها أحدّ إلا حمارًا، ولما كان الاستثاء معنى افتقر إلى ما يدل" عليه"(11).

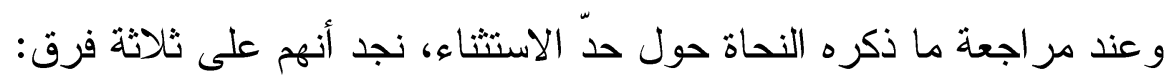




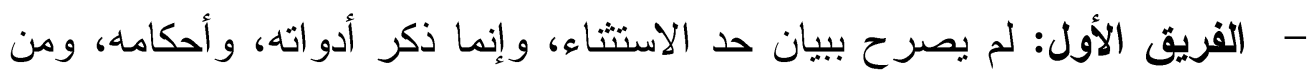

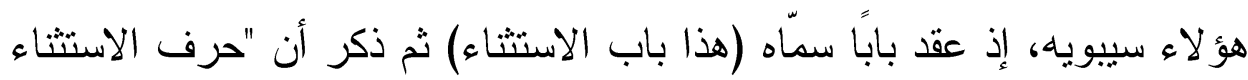

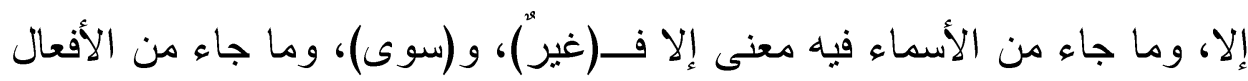

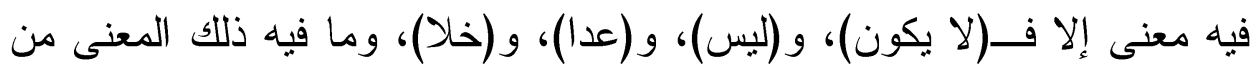

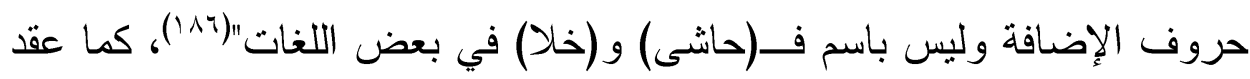

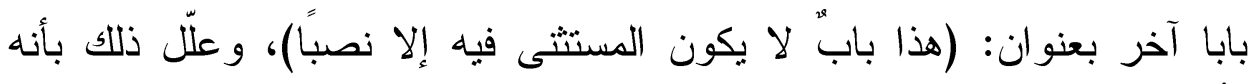

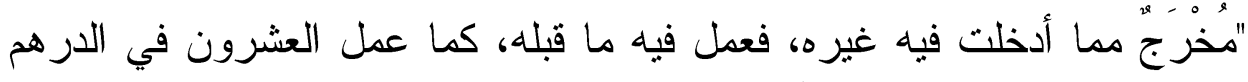

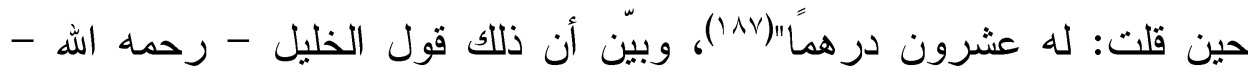

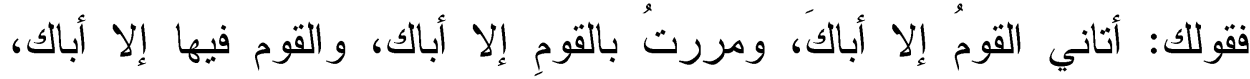

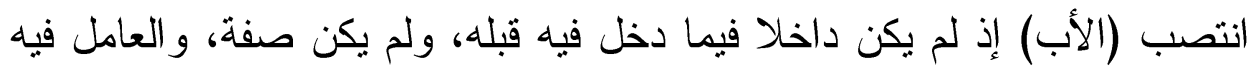

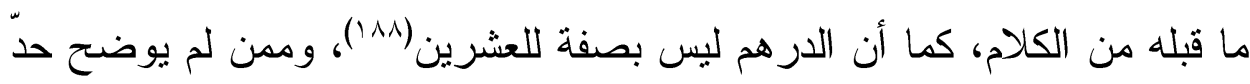

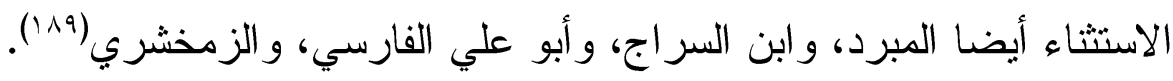

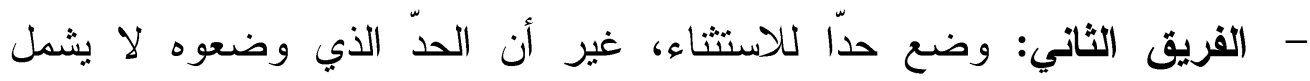

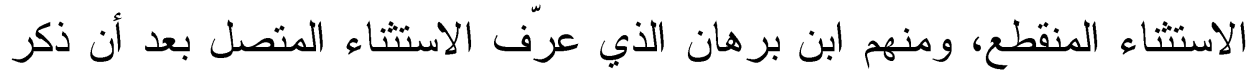

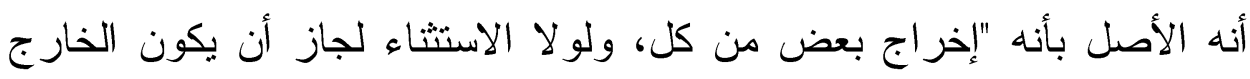

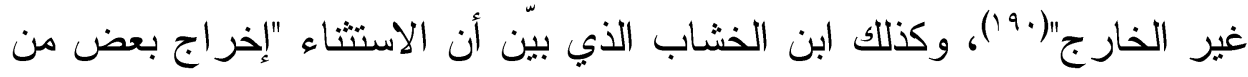

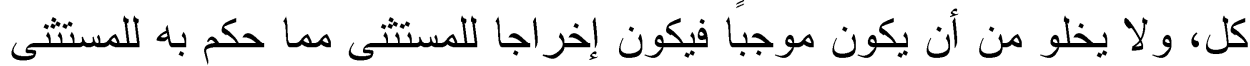

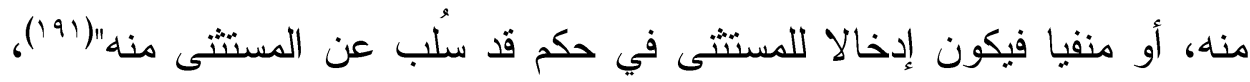

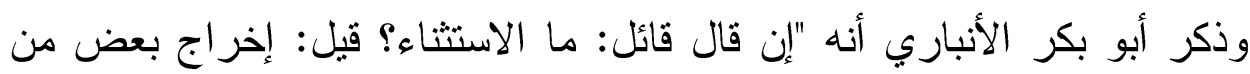

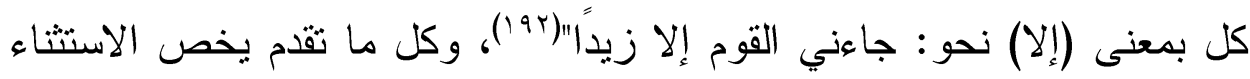

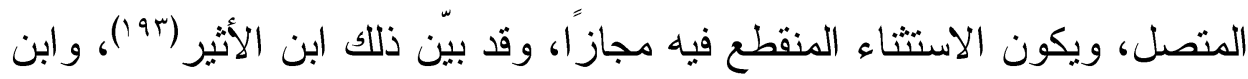

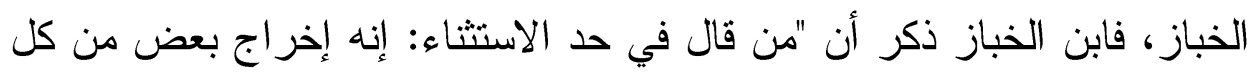

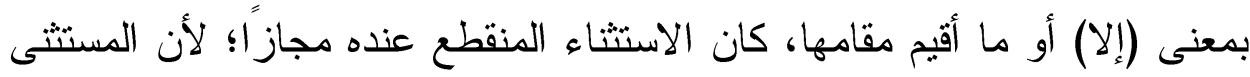

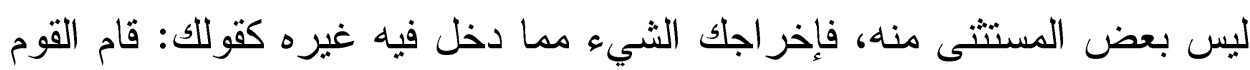

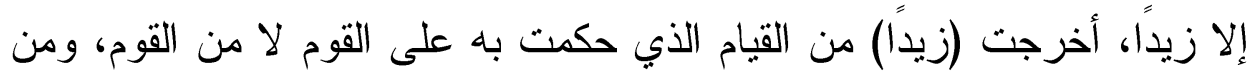


توهم ذلك فقد أخطأ. ألا نزى أنك لو قلت: قصدت العرب إلا قريشا، لم تخرج

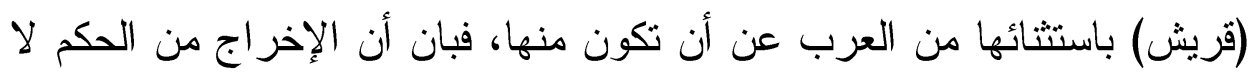

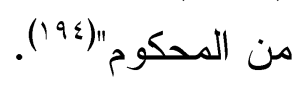

- - الفريق الثالث: وضع حدا للاسنثناء شمل الاستثناء المنصل و المنقطع، ومنهم ابن

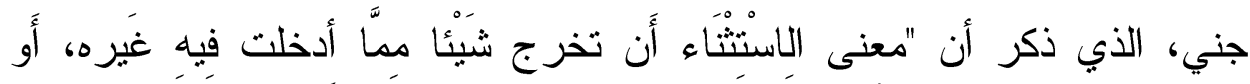

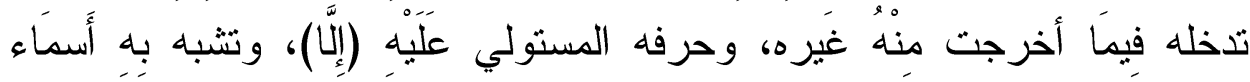

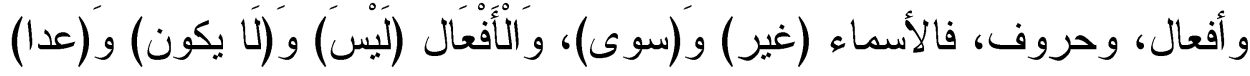

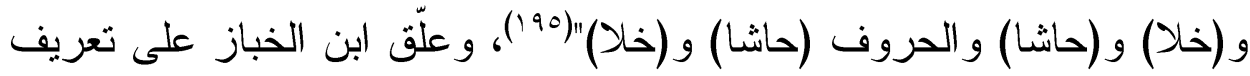
ابن جني للاستثناء بأنه "يوجب دخول واهيت الاستثناء المتصل، و الاستثناء المنقطع

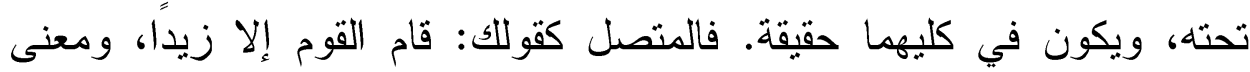
المتصل: أن يكون المستثى من جنس المستثثى منه. و المنقطع كقولك: ما فيها أحد إلا حمارًا، ومعنى المنقطع: أن لا يكون المستثنى من جنس المستثى منه، وكل واحد من المستثيين في المسألتين يصدق عليه أنه غير ما استثنى منه، فبان أن معنى الاستثاء عنده يشمل النوعين"(199 (19).

وذكر ابن مالك أن الاستثناء: "هو المخرج تحقيقا أو تقديرا من مذكور أو

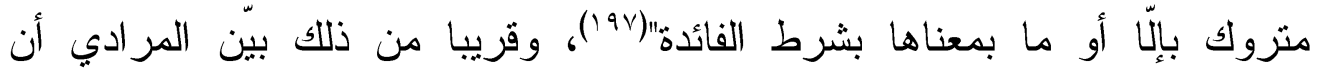

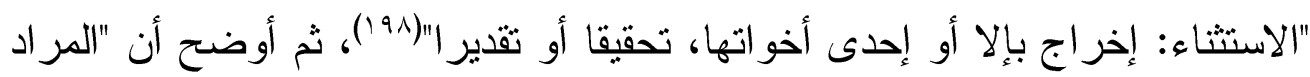

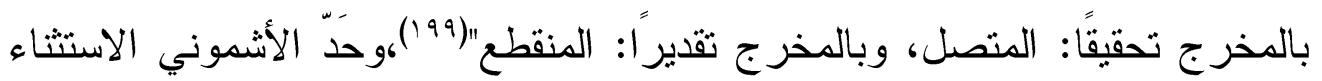

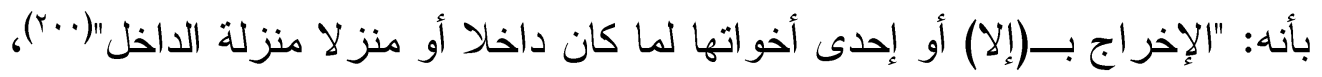

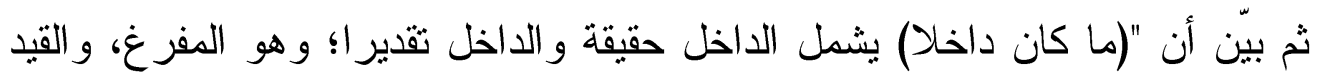

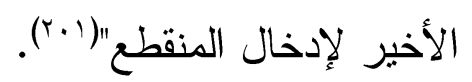

وبمر اجعة حدّ ابن مهران للاستثناء، نجد أنه يدخل ضمن الفريق الثالث، فقد

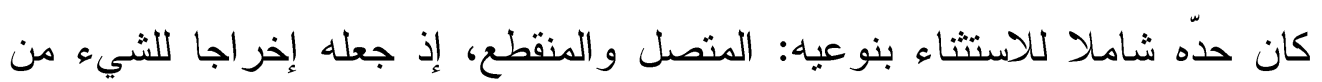
حكم غيره، لا إخر اجا لبعضه. 


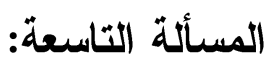

\section{نصب (غير) على الاستثناء:}

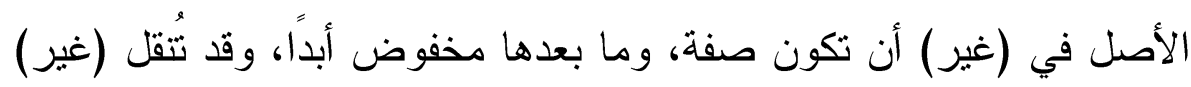

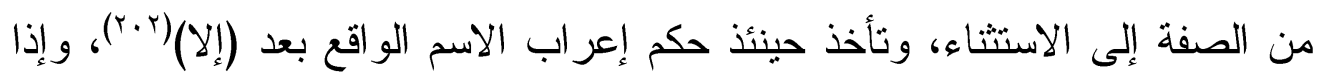

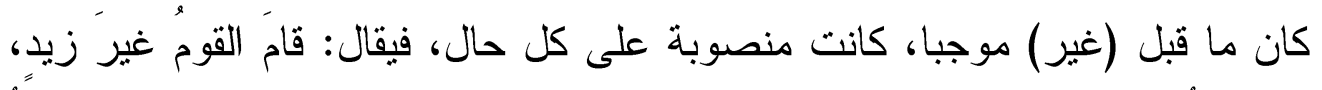

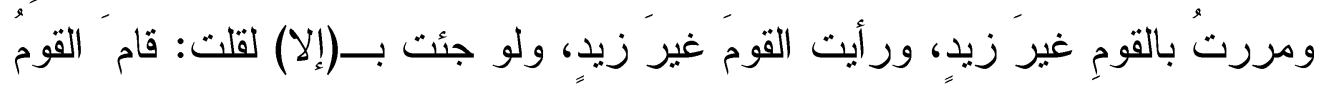

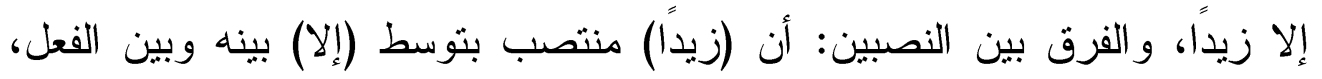

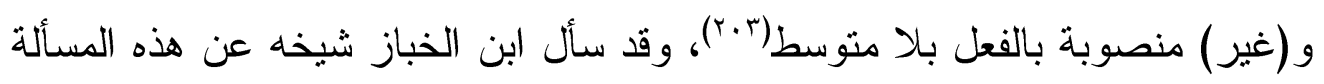

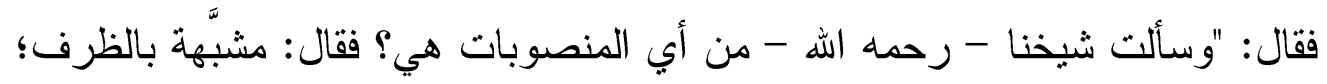

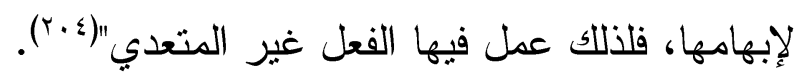
و الحديث هنا عن وقوع (غير) موقع (إلا) ونصبها إذا كان الاستثاء تاما

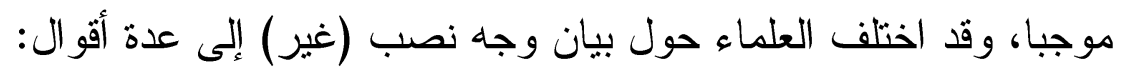

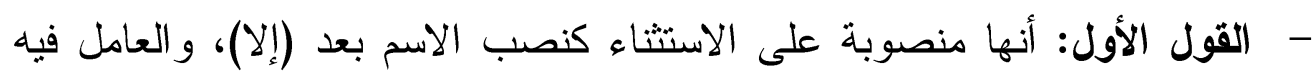

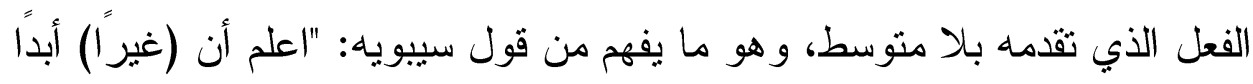

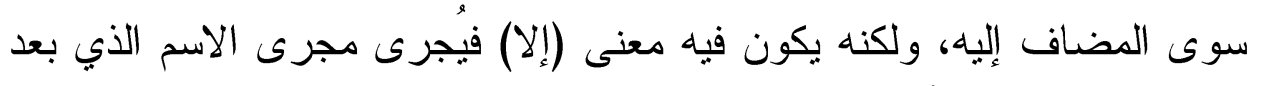

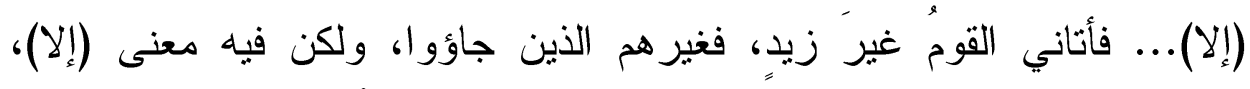

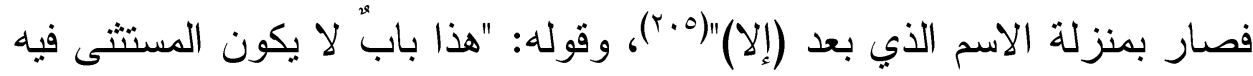

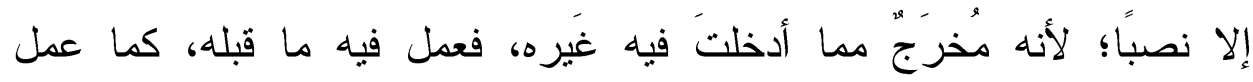

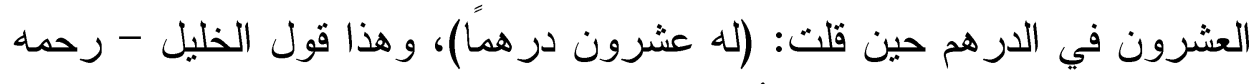

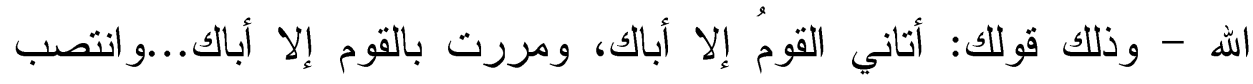

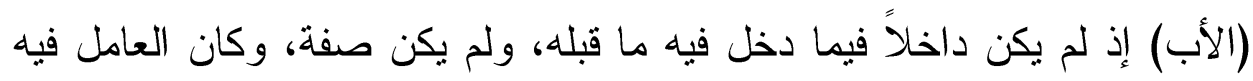

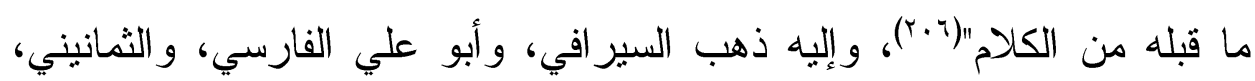

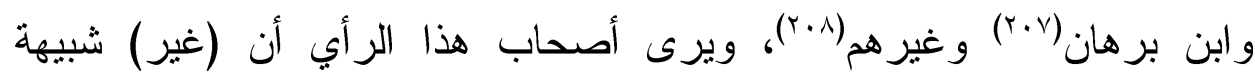

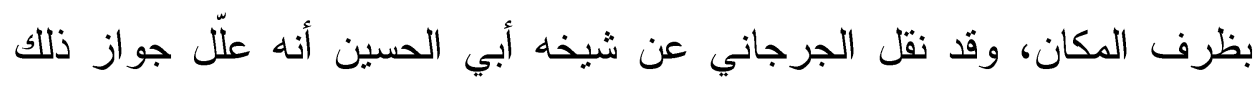


بـ"أن" (غيرًا) موضوع على الإبهام، ألا ترى أنك إذا قلت: مررت برجلٍ غيرك، فكل من جاوز المخاطب قد دخل نحت (غير) فلما كان فيه هذا الإبهام المفرط أثبه الظروف المبهمة نحو: (خلفك) و (أمامك)، فكما يتعدى الفعل غير المتعدي إلى الظروف بغير و اسطة، كقولك: جلست خلفك، كذلك جاز أن يتعدى الفعل إلى (غير) في قولك: جاعني القوم غيرَ زيدٍ، و إن لم يكن هناك واسطة

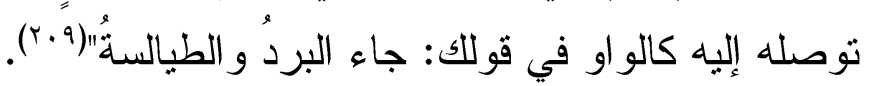

وقد خطّاُ ابن عصفور من ذهب إلى أن العامل في (غير) الفعل السابق، و علل ذلك بأن (غير) و غيرها من الأسماء قد تُتصب و إن لم يتقدمها فعل، نحو : القوم

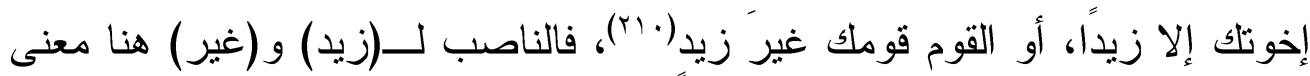

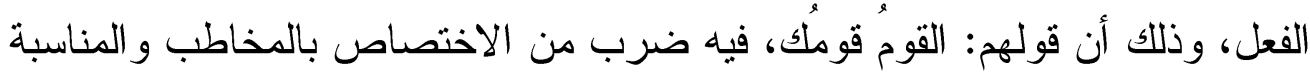

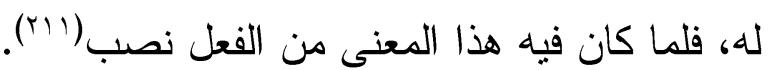
- القول الثاني: أنها منصوبة على الحال، وفيها معنى الاستثاء، و العامل فيها الفعل الذي قبلها، وهو رأي أبي علي الفارسي في أحد قوليه في (التذكرة)(rاب(r)، و اختاره ابن مالك، وخالد الأزهري، وذكر أنه الر اجح من قول سيبويه(rابr).

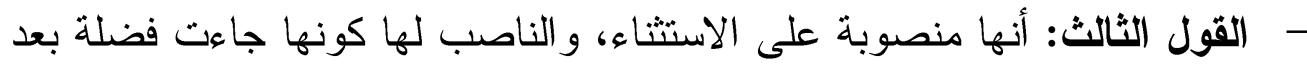

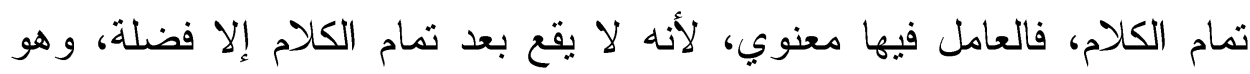

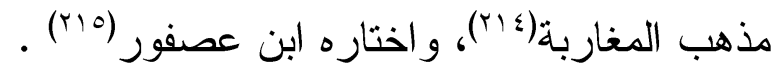

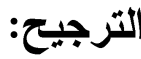

بعد النظر في الآراء المثقدة، أرى وجاهة كل من الرأي الأول والثاني، واستحسان الجمع بينهما، فابن مالك مثلا ذكر أن "الجواب عن نصب (غير) بلاء بلاء

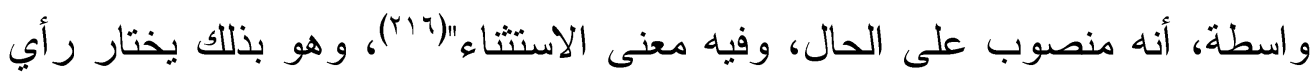
أبي علي، ويرى أنه الراجح من قول سيبويه، و المنصوب على معنى لا يقوم ذلك ولك الك

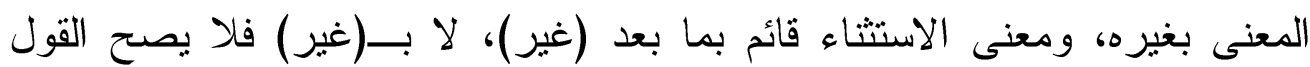

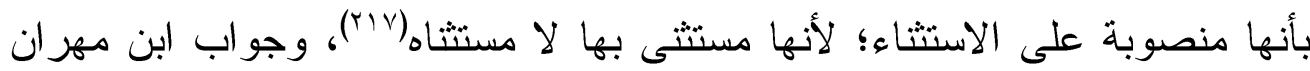


وما ذكره أصحاب الرأي الأول يتقارب مع ر أي أبي علي الفارسي، فالأصفهاني ذكر

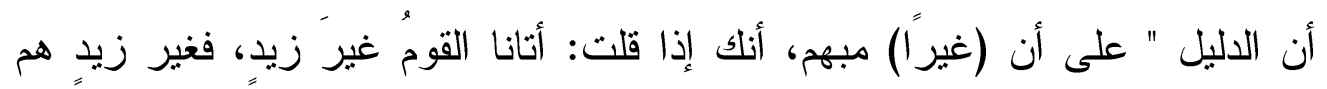

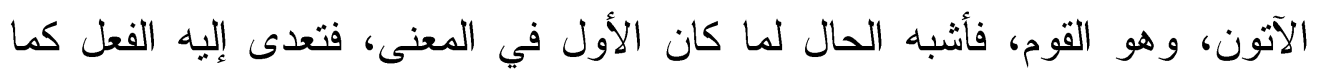

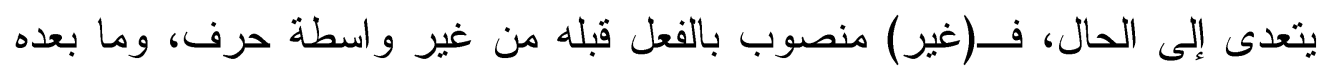

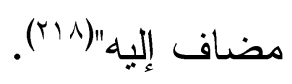

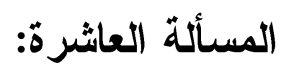

\section{وجه الاستقباح في قولهم: جئتك إذ زيد قام:}

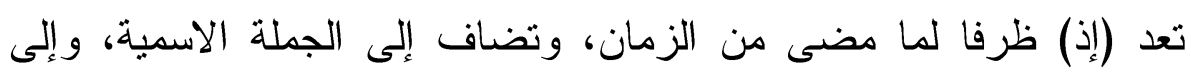

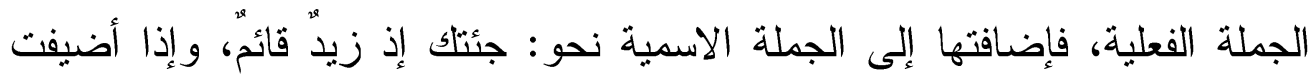

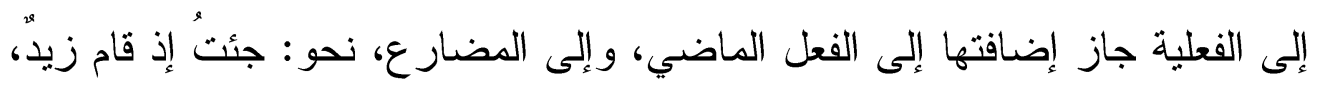

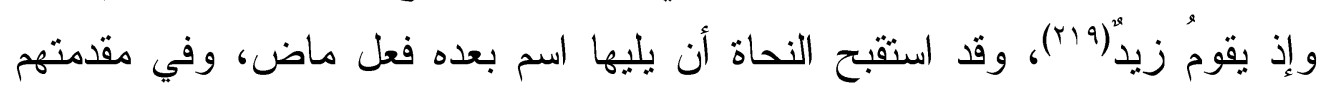

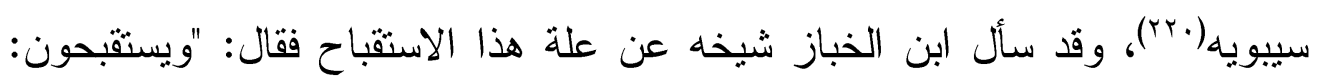

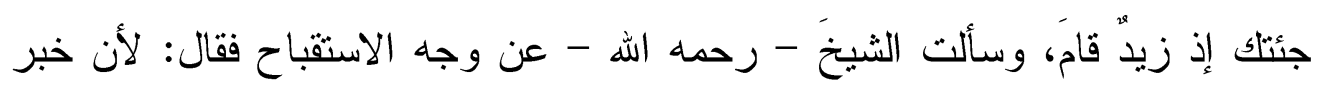

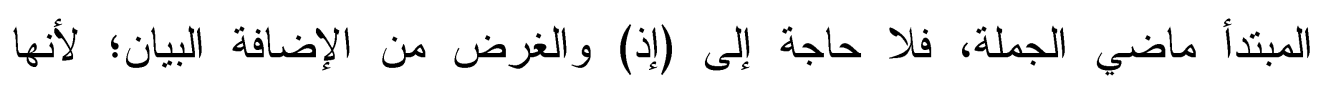
مبهمة"(r) المبندأ هاضي

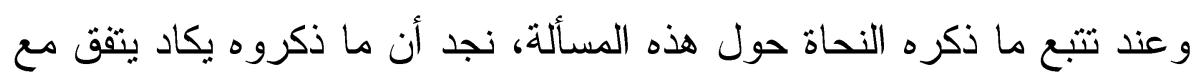

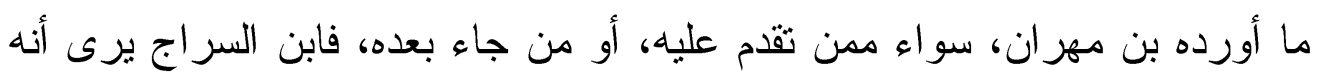

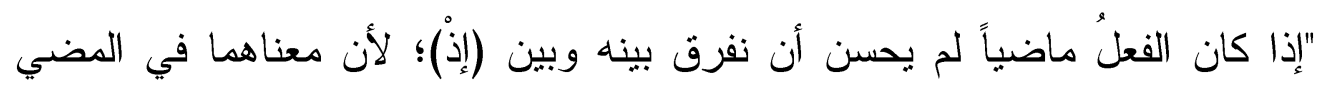

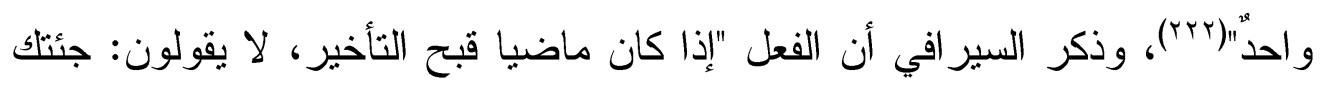

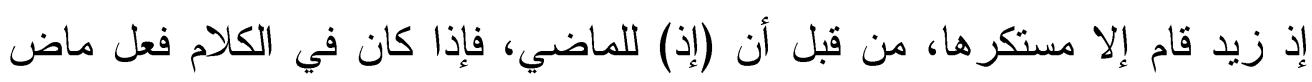

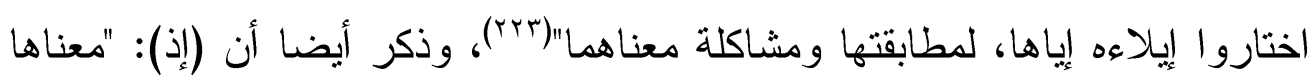

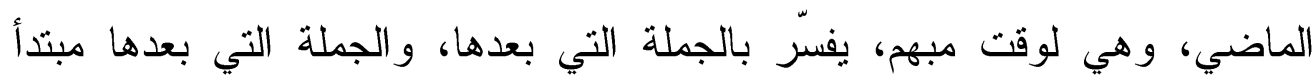

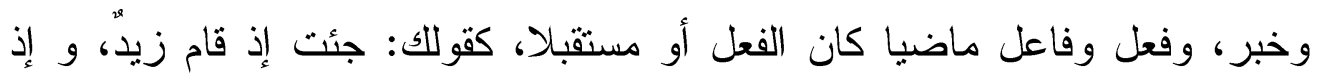

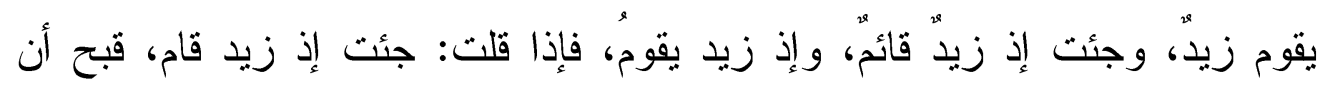

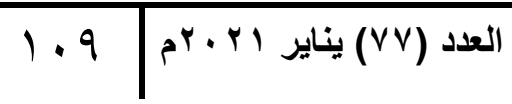


يكون خبر المبتدأ الذي بعدها فعلا ماضيا، فإن قال قائل: وكيف حسن: جئكل إذ قام زيد، ولم يحسن: جئنك إذ زيد قام؟ قيل له: لأن (قام) في قولك: زئل زيد قام، موضعها رفع بخبر الابتداء، وخبر الابتداء حكمه أن يكون الاسم أو ما يضارعه، ولها والفعل

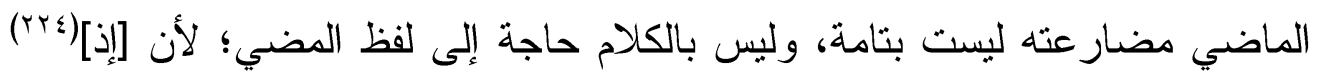
قد دلت على المضي، و إذا قلت: جئنك إذ قام زيد، فليس (قام) في موضع اسم، فإن قال قائل: فأنت تجيز : زيد قام، و لا تسنقبحه، و (قام) في موضع خبره، فلم استقبحت ذلك في (إذ)؟ قيل له: من أن قولنا: زيد قام، لو قلنا مكان (قام)، (يقوم)، لتغير معنى

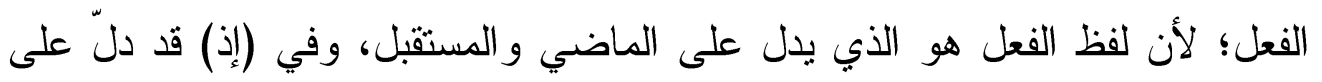

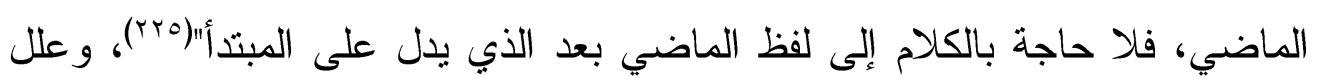

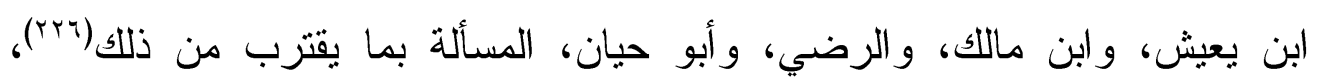

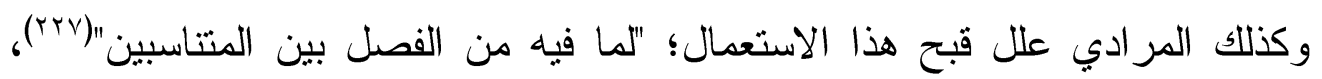

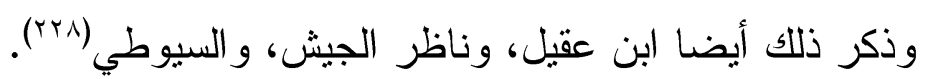
المسألة الحادية عشرة:

\section{التفريق بين الوصف والنعت:}

جرت عادة بعض النحويين على استعمال مصطلحي الوصف و النعت للالالة على ذات الثيء، وقد تتبّه ابن الخباز لهذه المسألة، مما دفعه لسؤال شيخه فقال: "وسألت شيخنا رحمه الله عن الفرق بين الوصف والنعت فقال: النعت يستعمل فيما يتغير، و الوصف يستعمل فيما يتغير وفيما لا يتغير، ولذلك يقال: صفات الله، ولا لال يقال: نعوت الله، ولم تستعمل العرب النعت إلا في غير الله"(Y9). و عند مر اجعة استعمال العلماء لكلا المصطلحين، وجدناهم فريقين: - الفريق الأول: يرى أصحابه أن النعت و الوصف مصطلحان منز ادفان، و لا فرق بينهما، فقد ذكر ابن جني أن "الصفة عند النحويين هي النعت"(·rr)، وبيّن العكبري أن "النعت و الوصف بمعنى"(rrrr)، و ابن يعيش يرى أن "الصفة و النعت

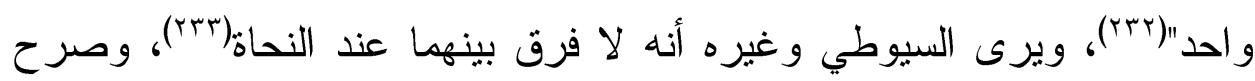


الأزهري و الزبيدي بأنهما مترادفان(\{r+)، وهناك من ذكر أن النعت مصطلح

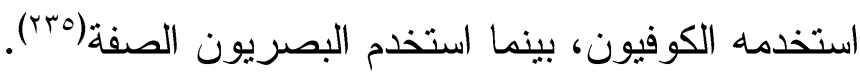

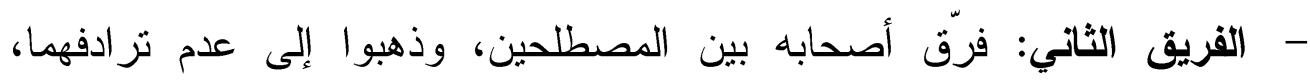

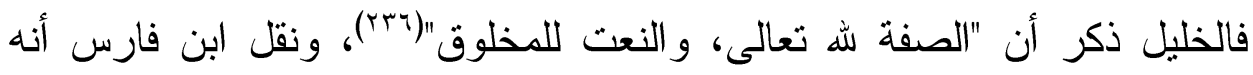

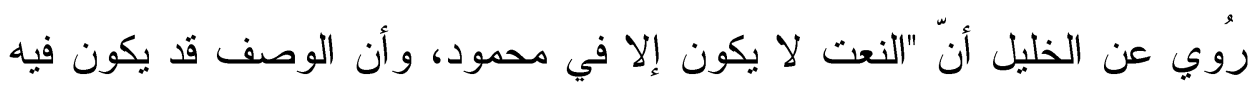

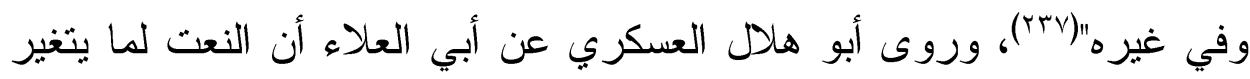

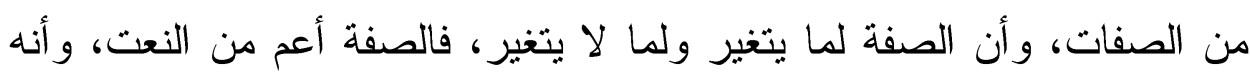

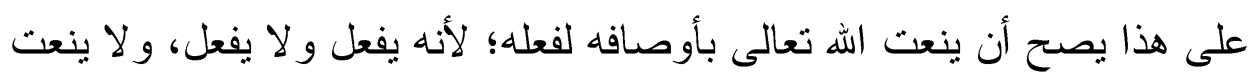

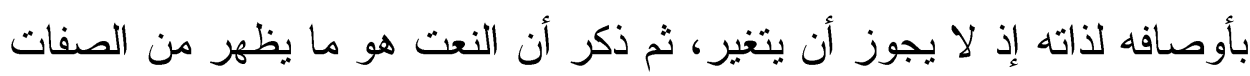

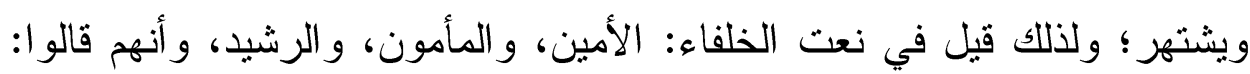

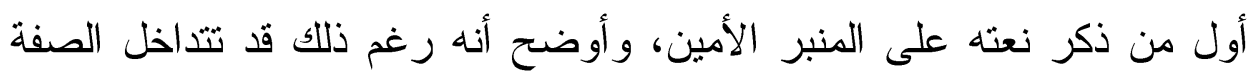

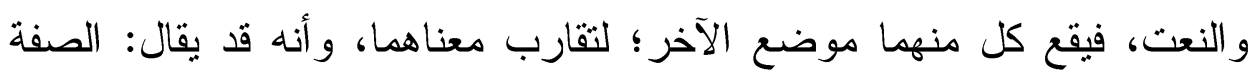

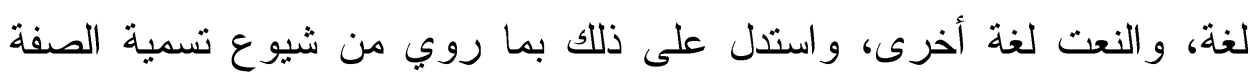

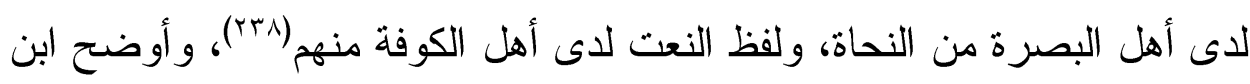

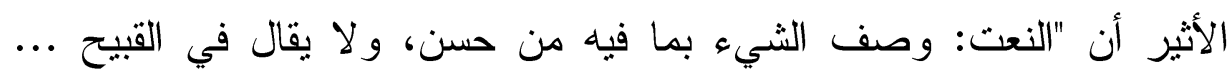

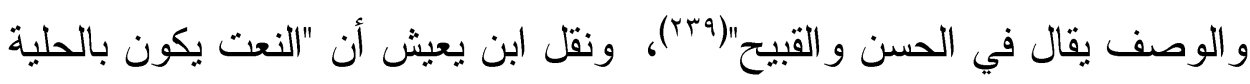

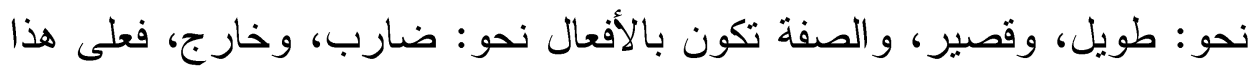

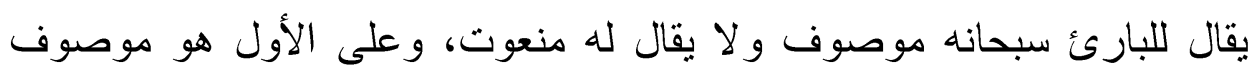

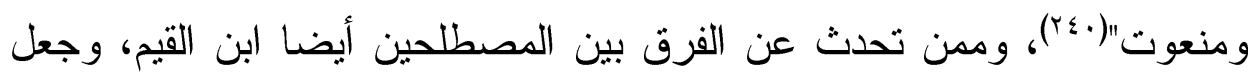

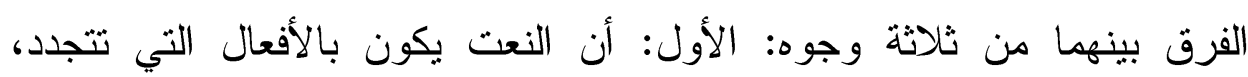

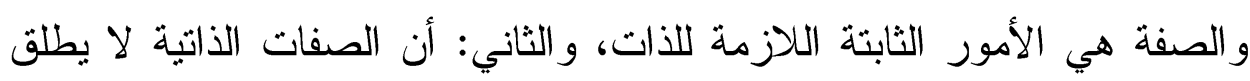

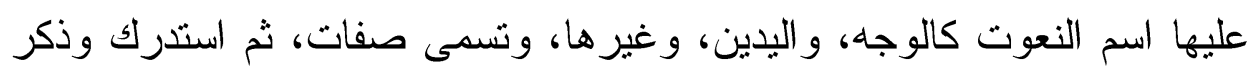

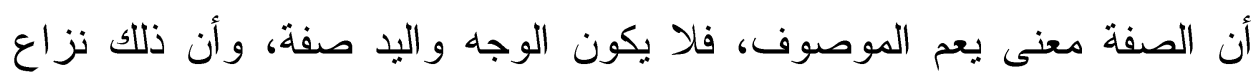

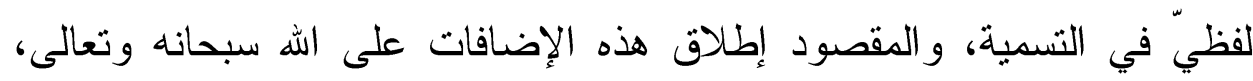

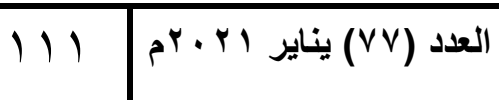


و الإخبار عنه بها منزهة عن التمثيل و التعطيل، سو اء سميث صفات أو لم تسم، و الثالث: أن النعوت ما يظهر من الصفات ويشتهر، ويعرفه الخاص و العام،

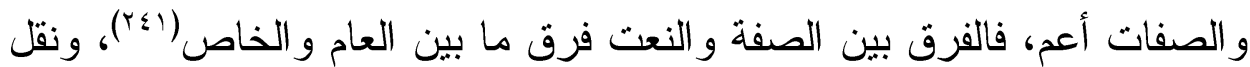

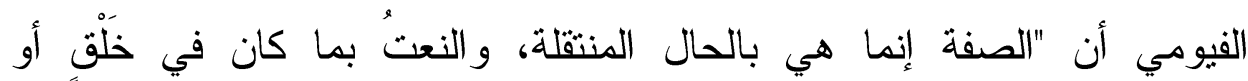

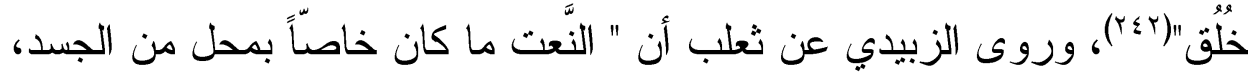

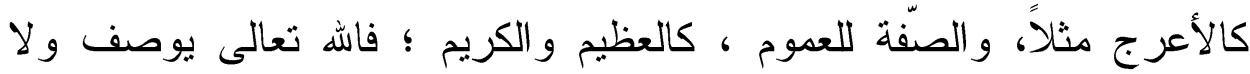

$$
\text { ينعت" (TST) }
$$

وذكر الأهدل أن التفريق بين المصطلحين إنما شاع عند غير النحاة، فـ"النعت: ما يمكن زو اله عن محله، كاللون العارض، و عدم العالمية في المخلوق،

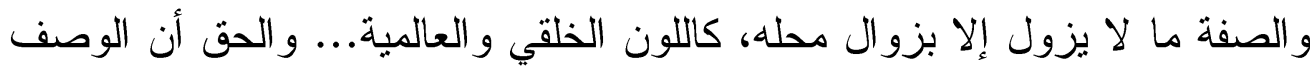
أعم عند النحاة؛ لأنه يقال: الحال و الخبر وصف معنى، و لا يقال: نعت معنى" (؛ ؟ب). و هنا أقول: رغم كل ما تقدم مما ذكره العلماء في الفرق بين مصطلحي النعت و الصفة، إلا أن هناك تداخلا بينهما، ويكاد بعض أصحاب المعاجم يسوّي بين

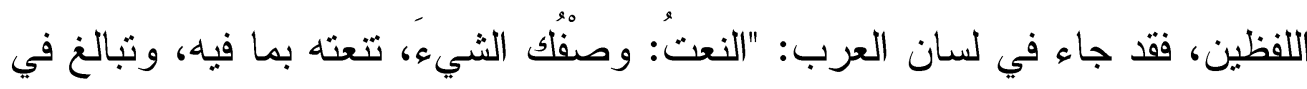

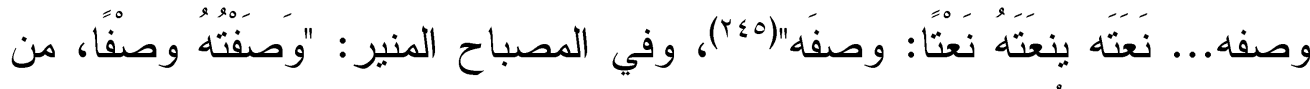

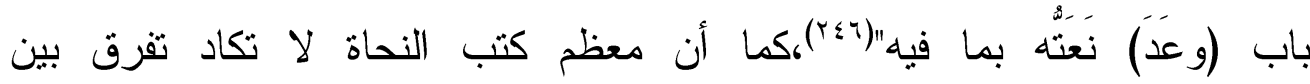
المصطلحين إلا قليلا كما أشرنا، إذ استخدموا كلا المصطلحين دون تمييز أحدهما

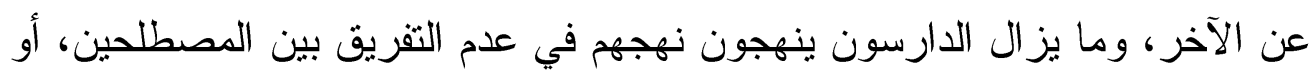
بيان ميزة أحدهما عن الآخر، وما ذكره ابن مهران في جوابه لابن الخباز، يقترب

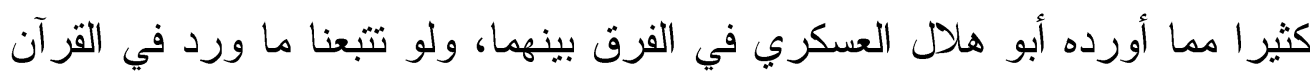

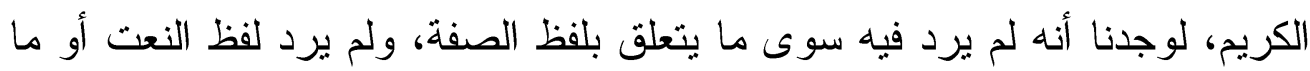
يتعلق به. وليس هذا نافيا لتقارب دلالة اللفظين، ولكن لعل فيه دلالة على شمولية لفظ الصفة، وأن فيه عموما إذ بشمل النعت، واستخدام النحاة أو الصرفيين للمصطلحين ولهن ولهين 
لا مشاحة فيه، و لا مزية فيه للفظ على آخر، ولكن ربما استعمل بعضهم لفظ النعت؛ لأنهم درجوا على استعمال لفظ الوصف في تعريف بعض المصطلحات، كاسم الفاعل، واسم المفعول، و الحال، و غيرها من المصطلحات.

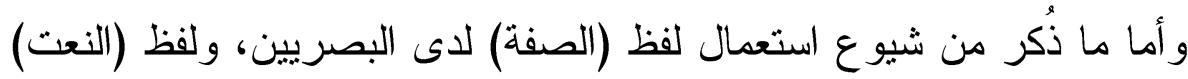

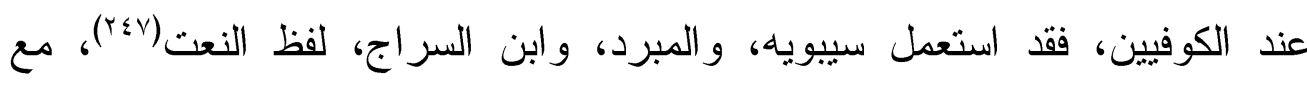
استعمالهم للفظ الصفة، دون تفريق بينهما في المعنى، ولعل هذا ما دفع الدكتور عوض القوزي للتصريح بأنه إذا "كان اصطلاح النعت قد انتشر على أيدي الكوفيين، فليس لهم فضل اختر اعه، فهم في ذلك متبعون لا مبتدعون، كما زعم الدكتور شوقي

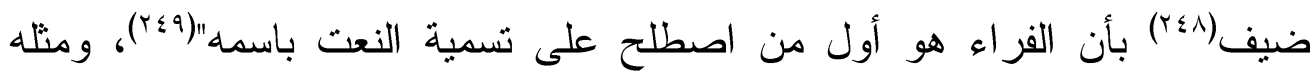

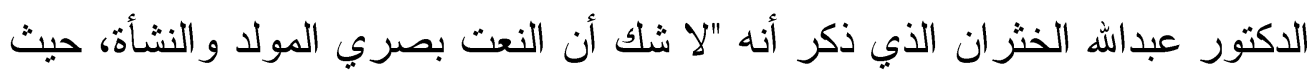
تكرر في كتاب سيبويه، و إن كان التعبير به أقل من الصفة، ولكن يبقى الفضل الأول للبصريين، أما الكوفيون فقد نسبه النحاة إليهم، وذللك لاقتصارهم عليه في التعبير دون الصفة، فلا بأس من عده من مصطلحات الكوفة.... حيث فضلوه على المصطلح الآخر"(10)، وكذلك بيّن الاكتور يوخنا أن نسبة المصطلحين إلى البصريين أو

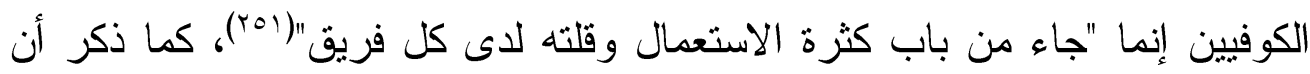
القدامى لم يستقروا على واحد من المصطلحين، أما المحدثون فقد استقروا على استعمال مصطلح النعت في أول وضع الباب المختص بهذا الموضوع(ror). ولو قارنا استعمال النحاة للمصطلحين باستعمال غيرهم له، لوجدنا تباينا، فلفظا الصفة والنعت يختصان عند النحاة بموقع إعرابي في الجملة، بينما هما في كلام الناس يستخدمان للالالة على معنى عام، بصرف النظر عن موقعهما من الكلام، فعلى سبيل المثنال لو قلنا: الجود يبارك في المال، فلفظ (الجود) في فهم عامة الناس، صفة يوصف بها المرء، بينما موقعه لدى النحاة مبندأ، وهذا جانب عام لسنا في مجال تفصيله أو التوسع فيه، ولكن ذكرته هنا عرضًا في مجال بيان عدم المشاحة في الاصطلاح بين استخدام لفظي الصفة أو النعت. 


\section{المسألة الثانية عشرة: - مثرة}

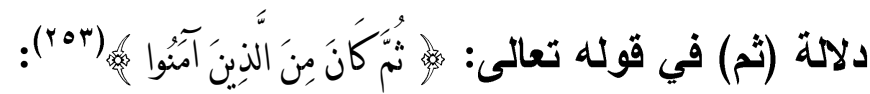

ذكر جمهور النحاة أن (ث) عند كونها عاطفة تفيد النشريك في الحكم،

و الترتيب، والمهلة(ro)، غير أن هذا الأمر ليس على إطلاقه، إذ لاحظ ابن الخباز وجود بعض السياقات الني قد تخرج عن ذلك، فكانت محل سؤال منه إذ قال:

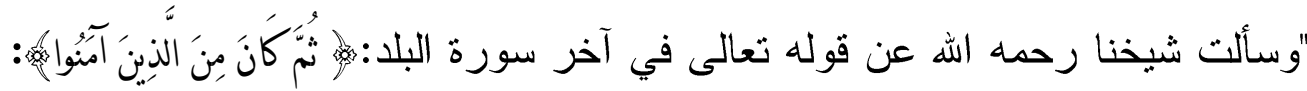
أين [المهلة](Y00)؟ وقد علم أنه إذا أطعم اليتيم وفلكّ الرقبة كان من الذين آمنوا، فقال: (ث) إذا دخلت على الجمل لا تفيد الترتيب"(ror).

و عند تتبع ما أورده العلماء فيها وجدنا لديهم عددا من الآراء في معنى (ثم) لئي

$$
\text { على النحو الآتي: }
$$

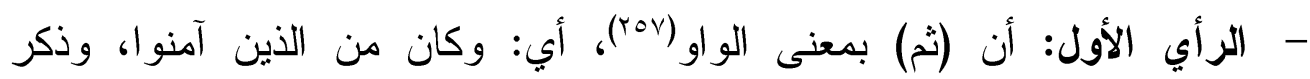

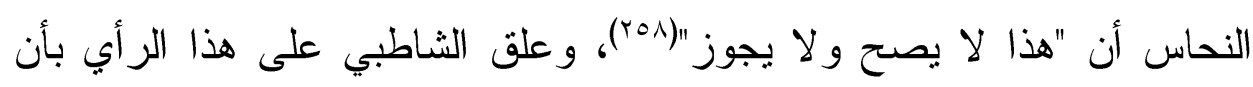
(ثم) في الآية لو "كانت للترتيب و المهلة لكان طلب الإيمان مرتبا على طلب فروعه، وذلك فاسد، فالمعنى: فلم يقتحم، و لا كان من الذين آمنوا، فالموضع

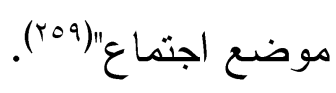

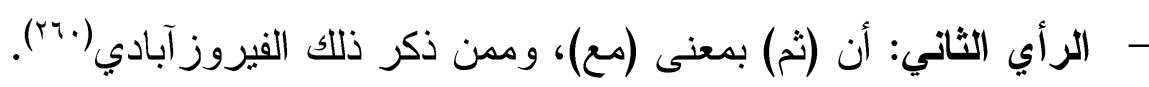

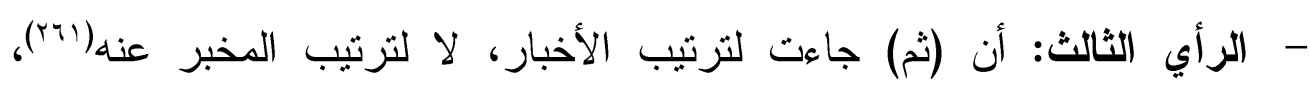

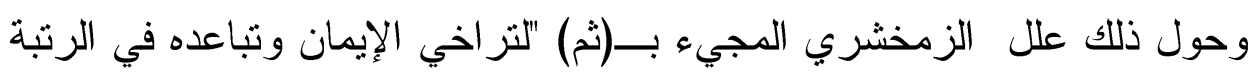

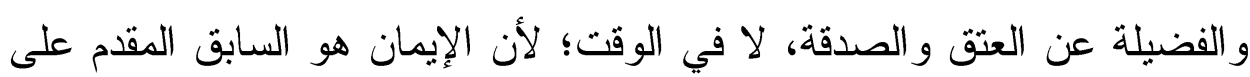

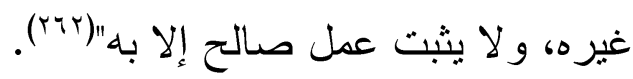
- الرأي الرابع: فصّل أصحابه وفرق بين دخول (ثم) على المفردات، ودخولها بهات

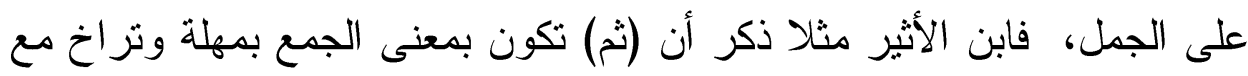

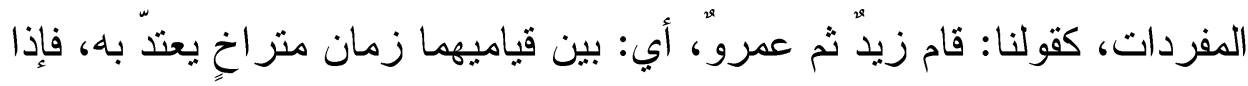


عُطفت بها الجمل لم يلزم الثراخي فيها، واستدل بعدد من الآيات من بينها آية

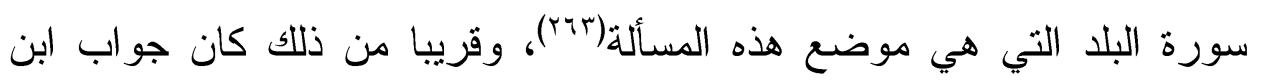

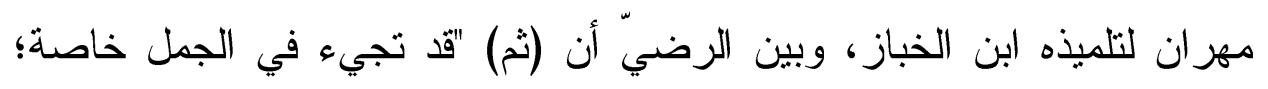
لاستبعاد مضمون ما بعدها عن مضمون ما قبلها، وعدم مناسبته لها...

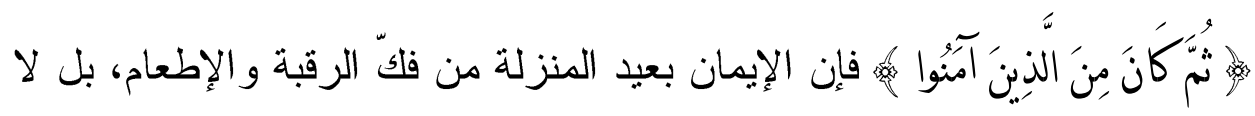

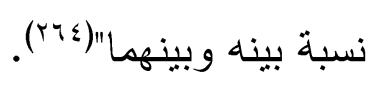

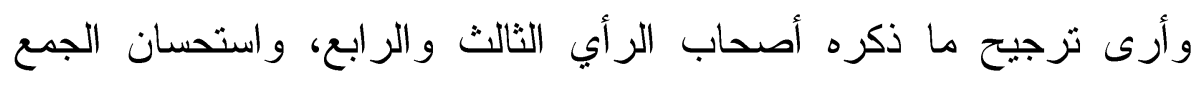

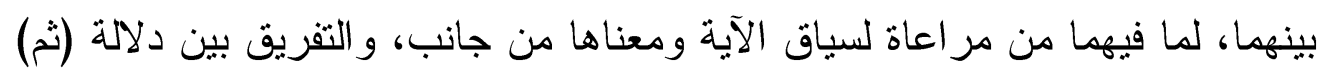

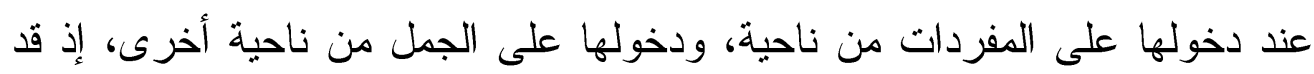
لا بستلزم دخولها على الجملة الدلالة على الترتيب و الثراخي.

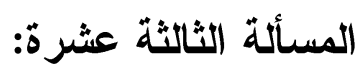

\section{لزوم التأنيث في منع الأعلام المختومة بتاء التأنيث من الصرف:}

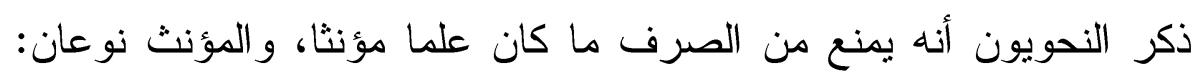

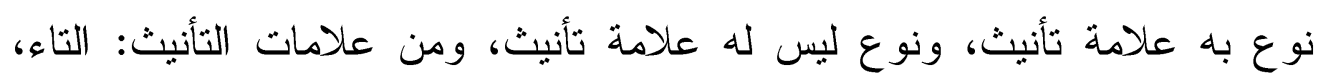

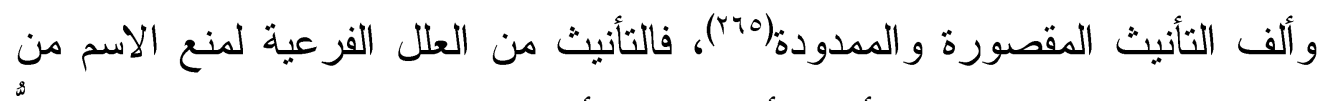

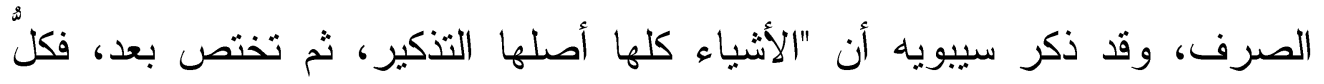

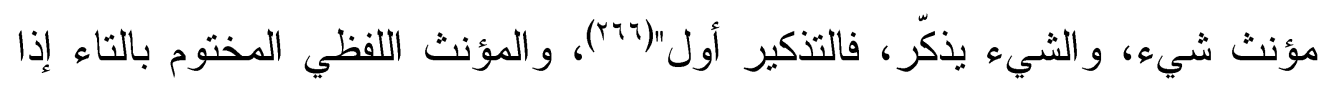

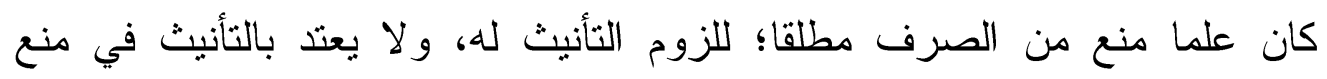

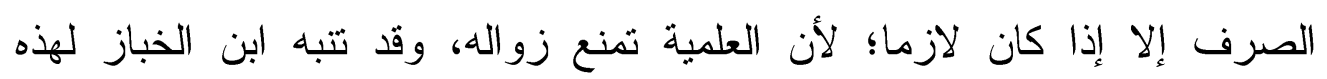

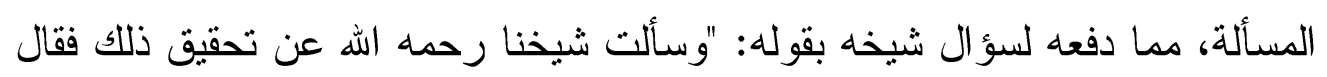

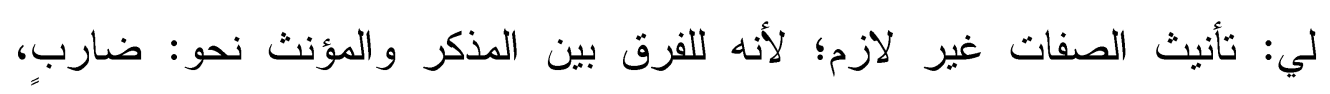

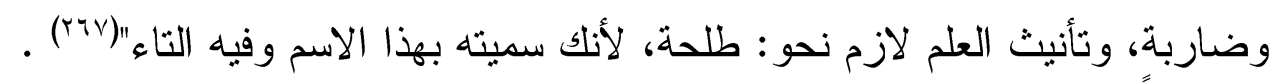
و عند تتبع ما ذكره النحاة في هذه المسألة، نجدهم فريقين: 
- الفريق الأول: تتبه للفرق بين التاء التي تدخل على الصفات، فيفرََّّ بها بين

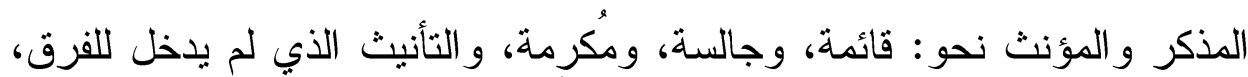

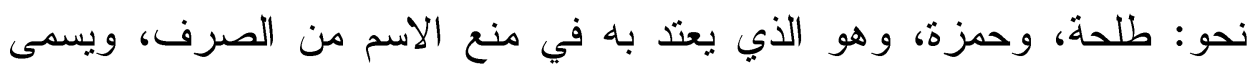

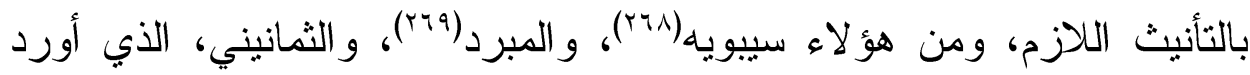

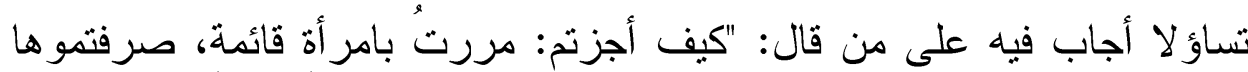

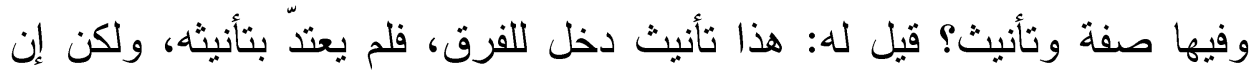
نقلنه فسميث بــ(قائمة) و (مكرمة) بطل أن يكون هذا التأنيث للفرق، وصهار

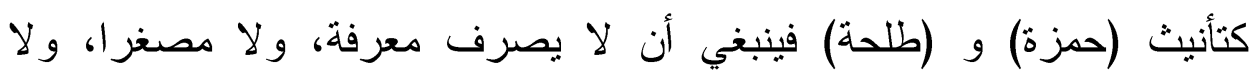
مكبر ا، وينصرف نكرة لزوال التعريف، وكذلك كل مؤنث أنث بالتاء التي تتقلب

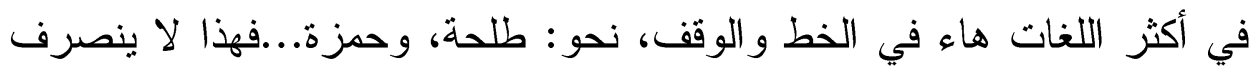
معرفة مصغر ا ولا مكبرا، وينصرف نكرة"(rVI)، وذكر ابن يعيش أن النأنيث اللازم هو "وصف احترز به عن تأنيث الفرق، وهو الفارق بين المذكر و المؤنث

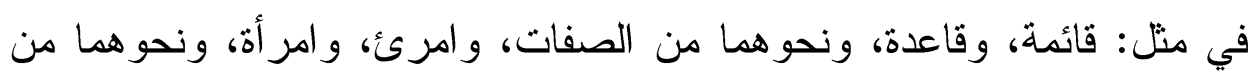

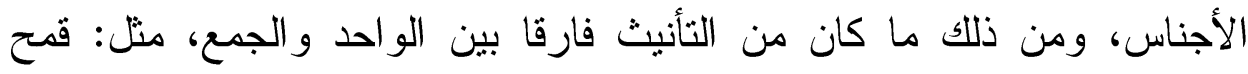
وقمة، وشعير وشعيرة، فهذا التأنيث لا اعنداد به، و إنما المانع من الصرف وهن

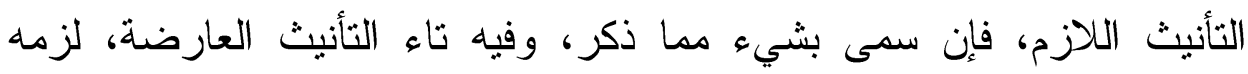

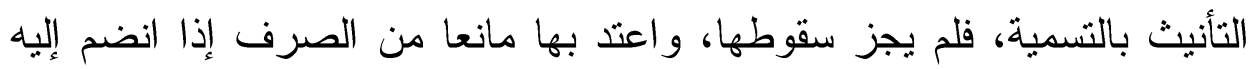

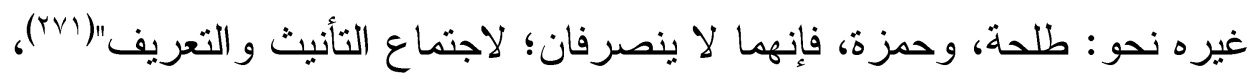

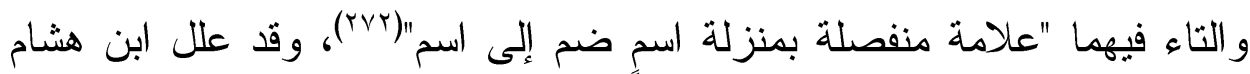

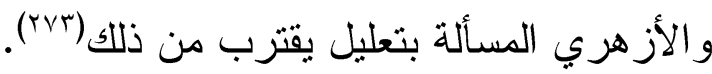

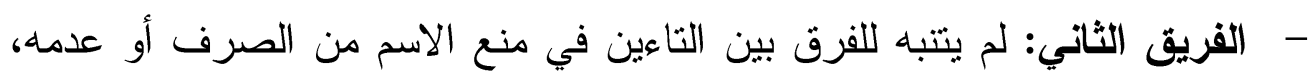
ومن هؤلاء السهيلي، الذي اتهم النحاة بوجود التناقض والفساد في عللهم التي ذكروها حول منع الاسم من الصرف(YY)، ومما يتعلق بهذه المسألة أنه ذكر أن

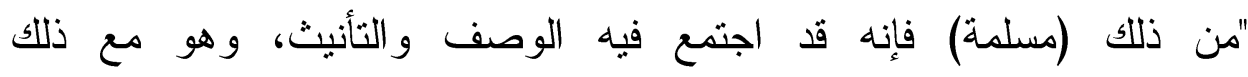


منصرف"(rVo)، والحق أن ما ذكره النحاة حول التأنيث بالتاء في منع الاسم من الصرف، عارض في الصفات، إذ اشترطوا أن يكون لازما كما ثقدم، وقد فصّل انّل العكبري ذلك بأن "تاء التأنيث غير لازمة، بل دخلت للفرق بين المذكر و المؤنث

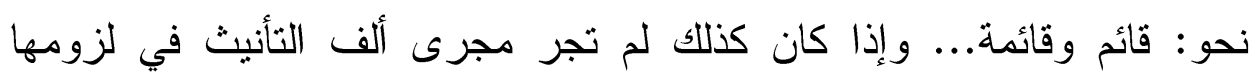
و استقلالها بمنع الصرف، بل لابد أن ينضم إلى ذلك التعريف، بأن تعلّق الاسم

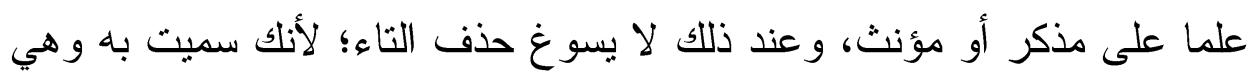
فيه، فإن قيل: فلم صرف ضاربة ونحوه وفيه الوصف و الثأنيث؟ قيل: التأنيث

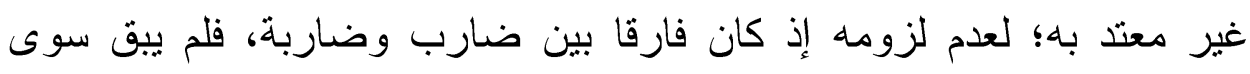

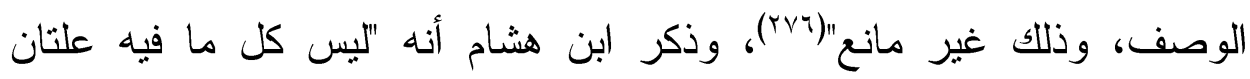

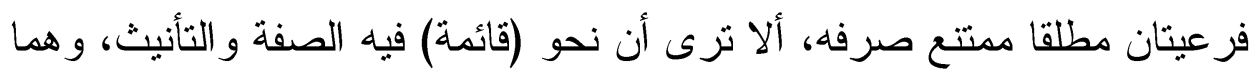

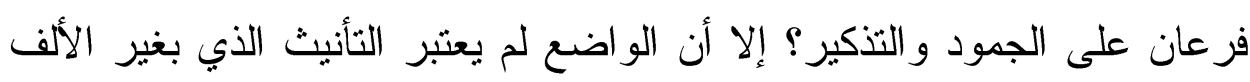
إلا مع العلمية؛ لأنه لا يكون لازما إلا معها"(rVV)

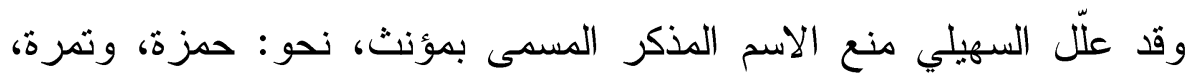

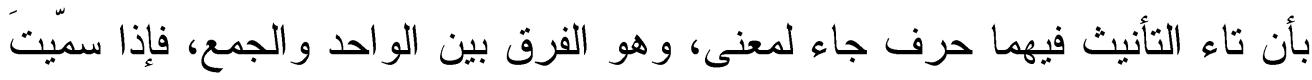

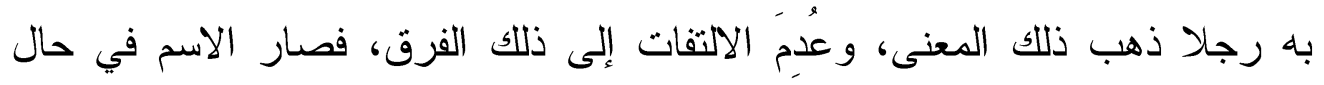
العلمية كــ(عمر) الذي عدمت فيه بنية عامر، و غير عن وزنه، فهو يرى أنه أن (حمزة)

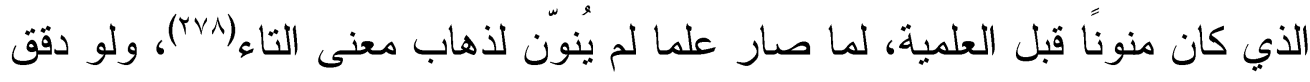
السهيلي في ما ذكره النحاة، لسلم من هذا الخلط، ولم يقع في مخالفتهم، ولسلم من لهن هذا التكهن ومحاولة اختلاق علل جديدة. المسألة الر ابعة عشرة: علة موافقة بني تميم لأهل الحجاز في كسر ما آخره راء إذا كان علما:

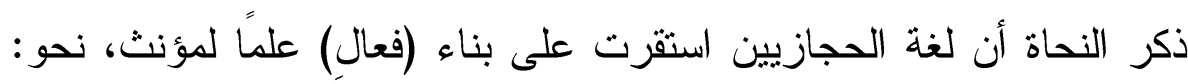

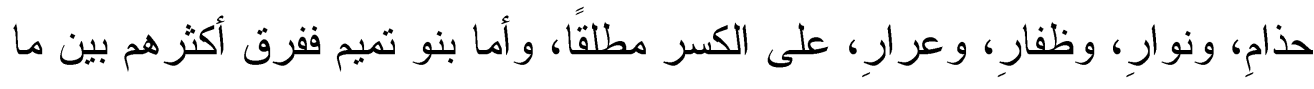

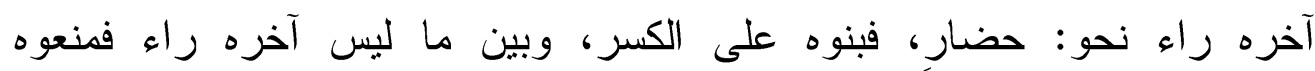

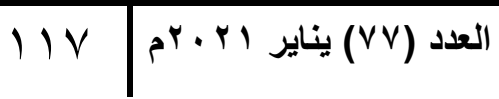




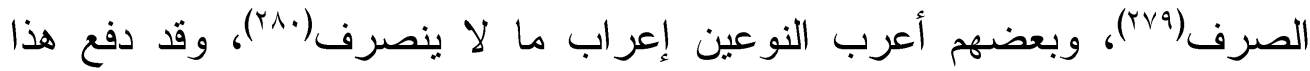
التقصيل عند بني تميم ابن الخباز إلى سؤال شيخه فقال: "وسألت شيخنا رحمه الله عن علة موافقتهم أهل الحجاز في كسر ما آخره راء، فقال: لأن بني تميم لغتهم الإمالة، فلو أعربوا ما آخره راء لضموه وفتحوه، و الراء تمنع الألف من الإمالة

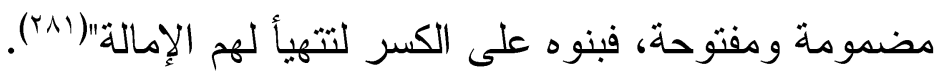

و هذه العلة التي أوردها ابن مهران، ذكرها عدد من النحاة مدن ثقدم عليه،

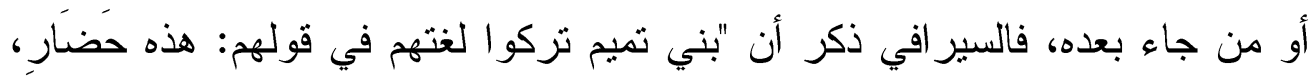
وسفَار، وتبعوا لغة أهل الحجاز بسبب الراء، وذلك أن بني تميم يختارون الإمالة،

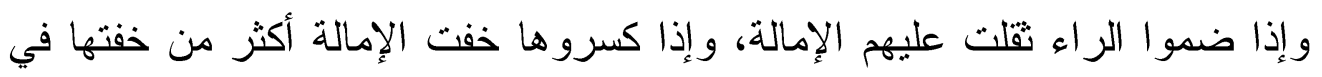

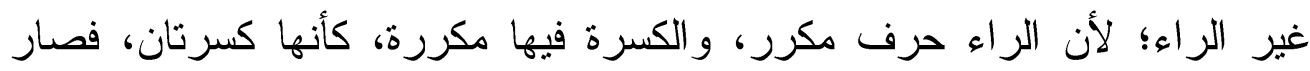
كسر الراء أقوى في الإمالة من كسر غيرها، وصار ضم الر اءه في في منع الإمالة أثند

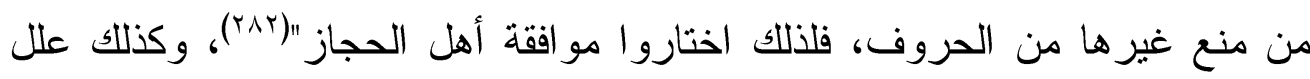
ابن الوراق هذه المسألة بأنه "إنما اختار بعض بنغ هني تميم الكسر، لأن الإمالة فاشية في

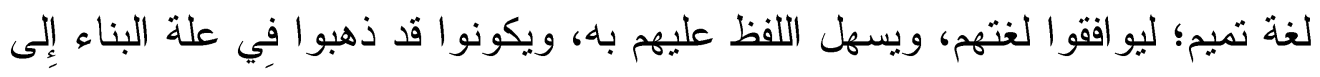
ما ذهب إليه أهل الحجاز وبعض بني تميم، فما كان آخره راء، بمنزلة ما ليس في ولي آخره راء، ويصبر على قياسه"(rAr).

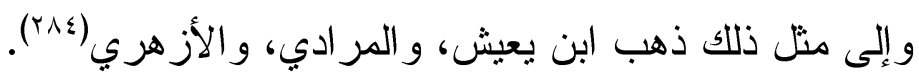

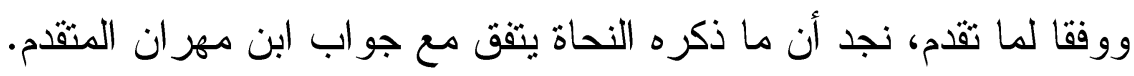

المسألة الخامسة عشرة:

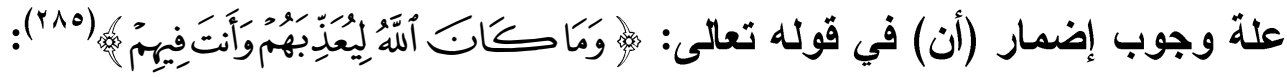
اختصت (أن) من بين نواصب الفعل المضارع بأنها تعمل في حال كونها

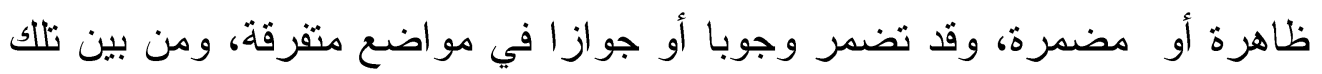
المواضع أن ثتقدمها اللام، وتكون حينئذ بين ثلاثة أحوال: إما أن يجوز معها إظهار 
(أن) وتسمى حينئذ لام كي، أو لام التعليل، أو يجب إظهار (أن) إذا وقعت بين لام إم إن إنها

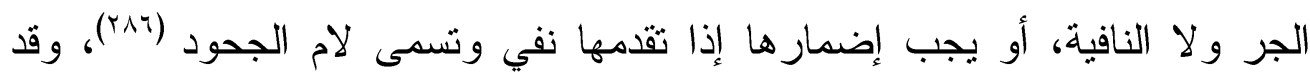

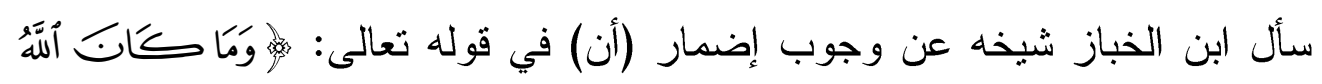

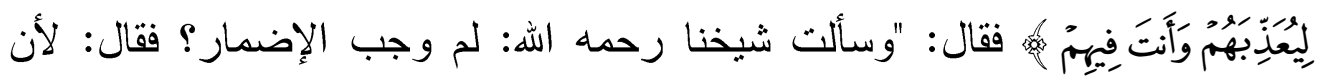

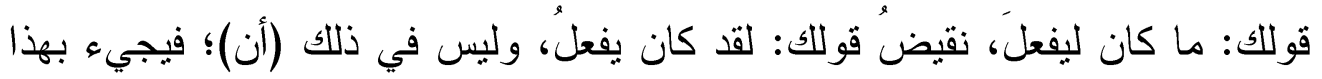
على طريق ما يناقضهة"(بN").

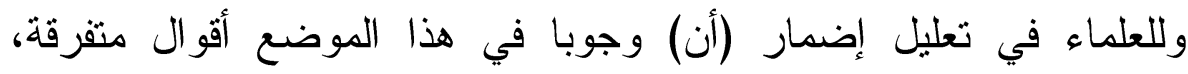

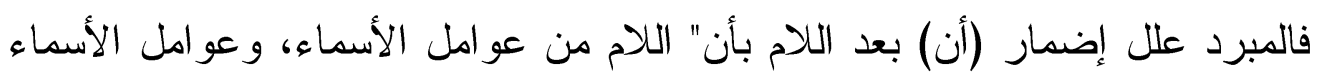

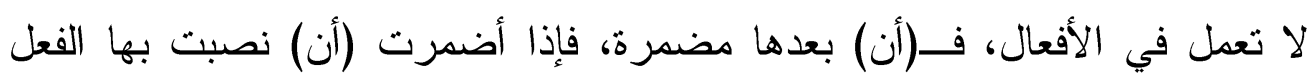

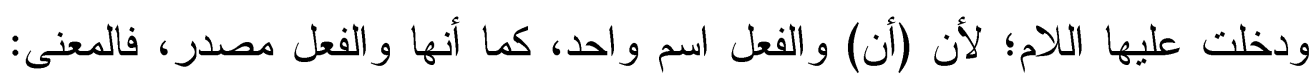

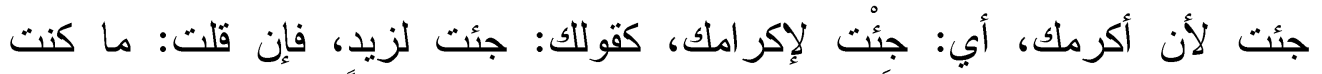

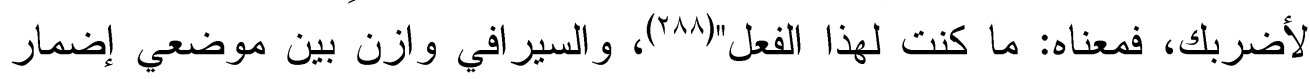

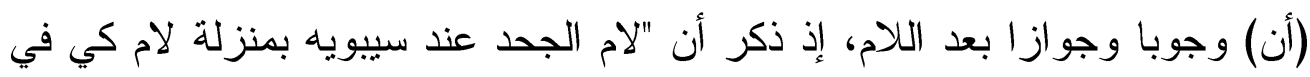

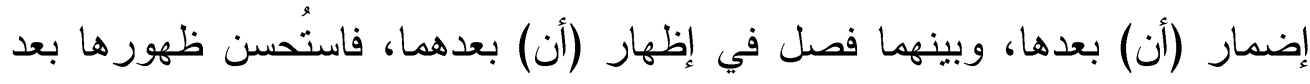

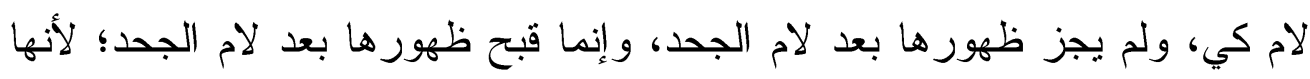

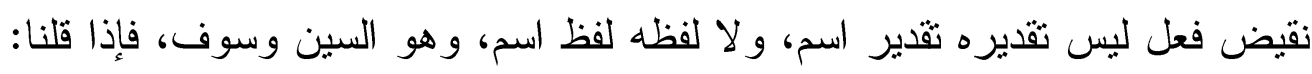

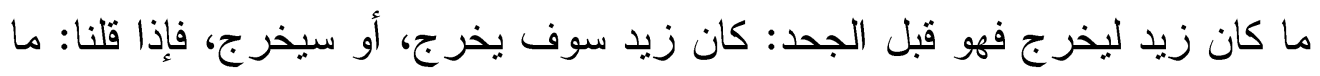

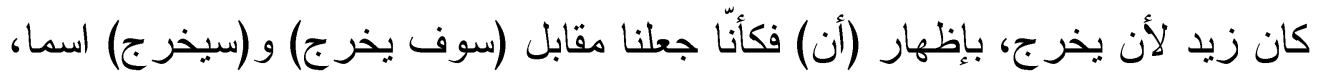

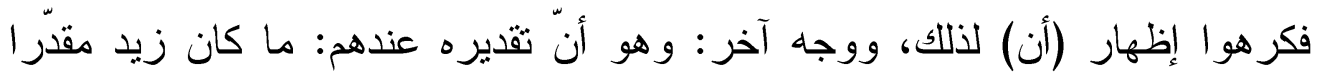

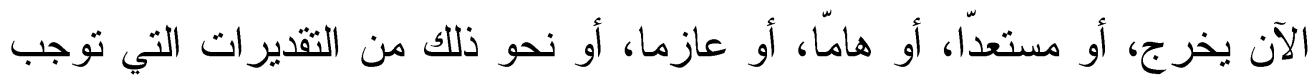

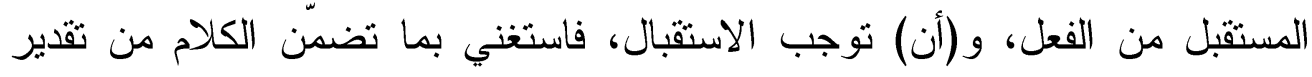

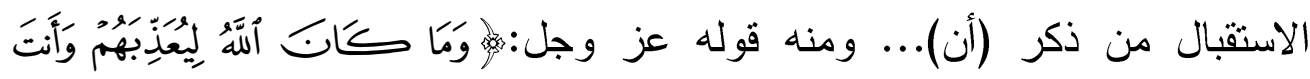

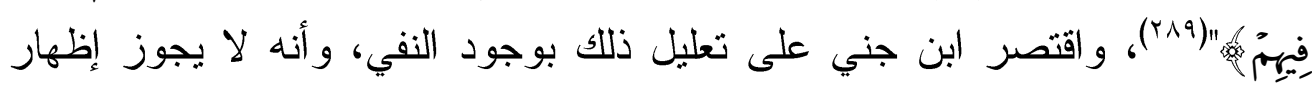

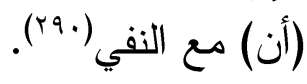

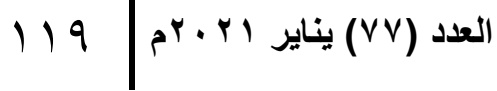




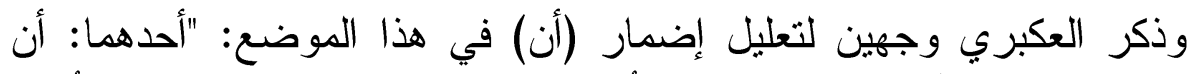

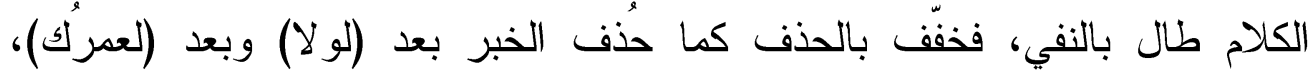

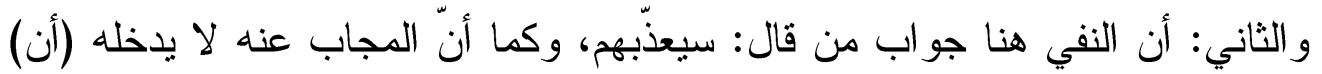

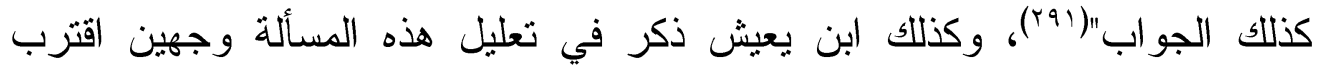

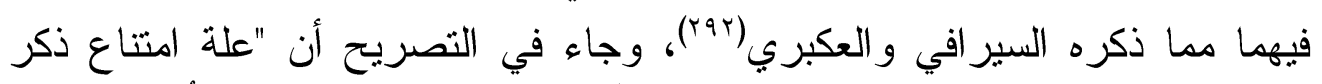

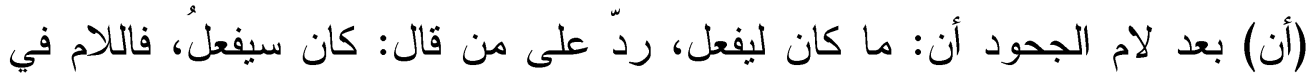

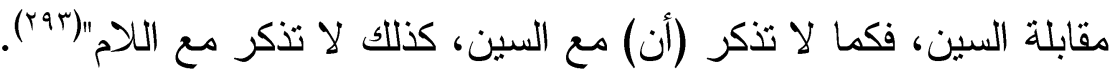

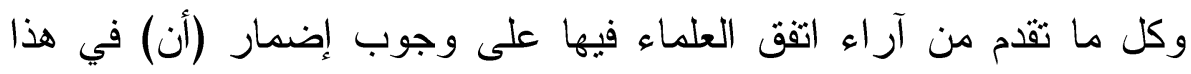

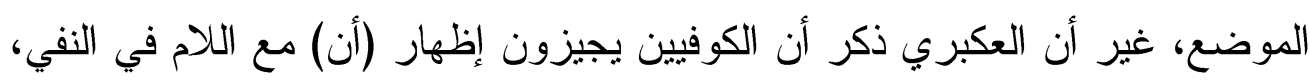

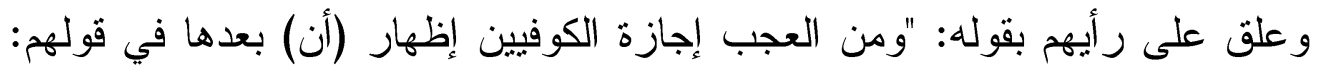

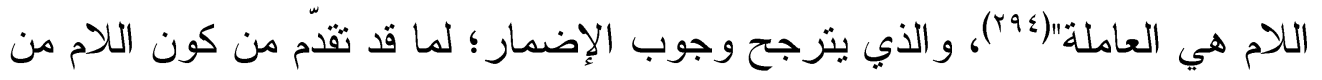

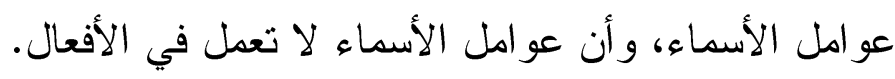

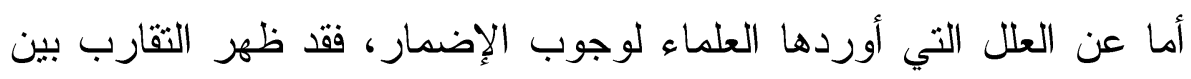

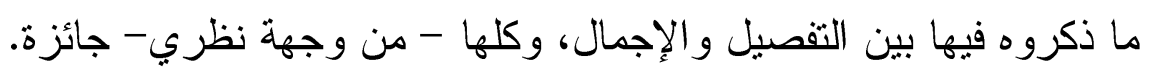

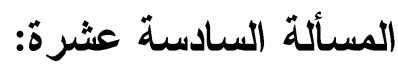

جواز الرفع في جواب الثرط إذا كان الثرط ماضيا والجو اب مضارعا:

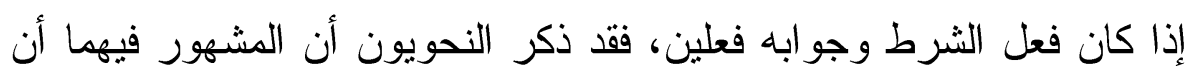

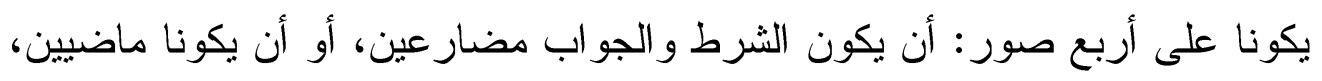

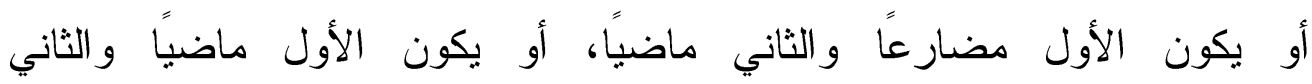

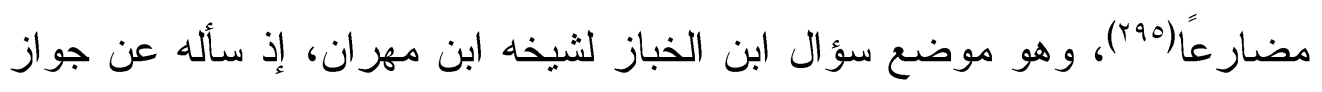

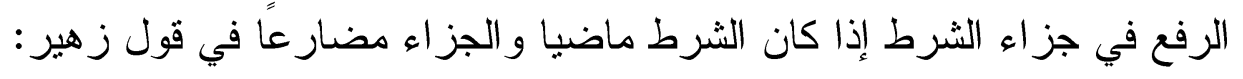

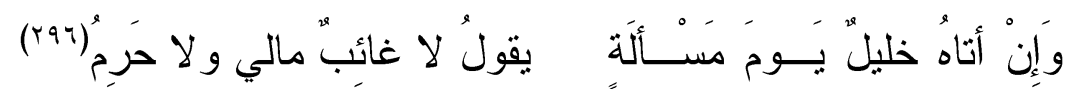

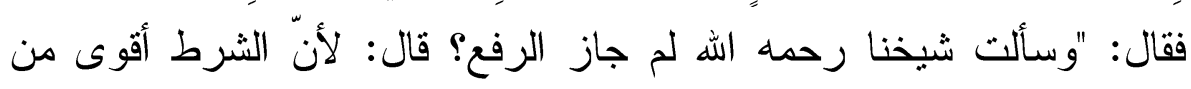
الجواب، وذلك لم يظهر فيه الجزم، فجيء بهذا مثله"((rav). 
وقد اختلف النحاة حول تخريج المرفوع الو اقع موقع الجو اب، وكان لهم عدة أقو ال على النحو الآتي: - ملي - القول الأول: أن الجواب محذوف، والمذكور دليل على الجواب، وهو على نية

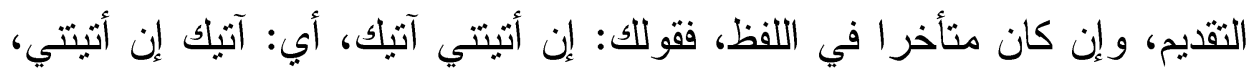

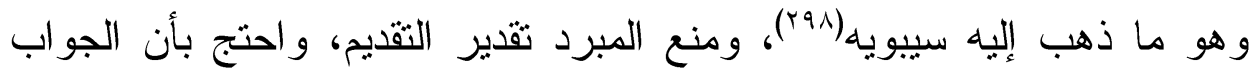

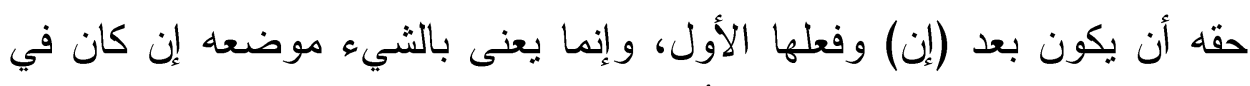

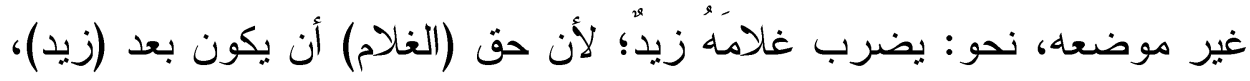
و هذا قد وقع في موقعه من الجزاء، فلو جاز أن بعنى به التقديم، لجاز أن نقول:

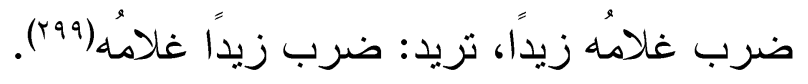
- القول الثاني: أنه هو الجواب، و الفاء منه محذوفة، وهو ما ذهب إليه المبرد

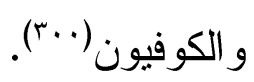

- القول الثالث: أنه هو الجواب، وليس على نبة التقديم، و لا على حذف الفاء، بل

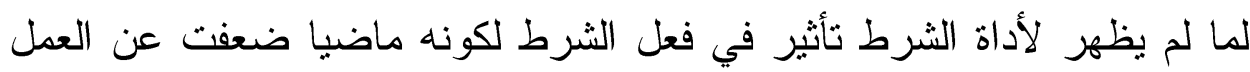
في الجواب، وهو ما ذهب إليه بعض النحاة كالجرجاني، والأنباري، والصايغ،

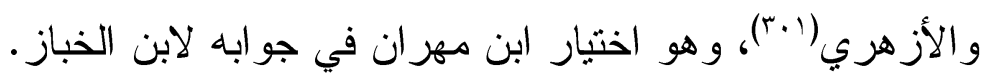

والأي يترجح: القول الثالث؛ لجواز كونه مرفوعا في اللفظ مجزوما في

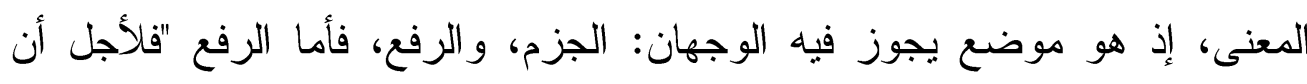

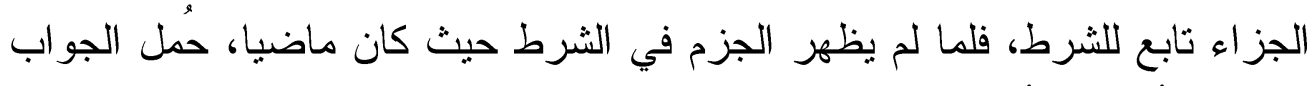

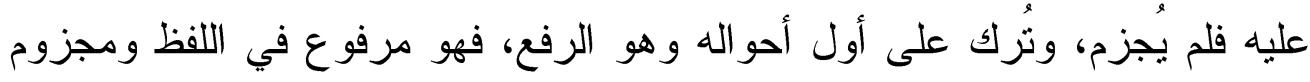

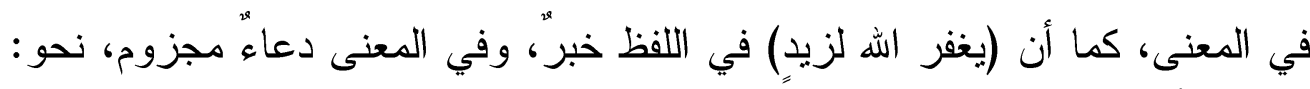

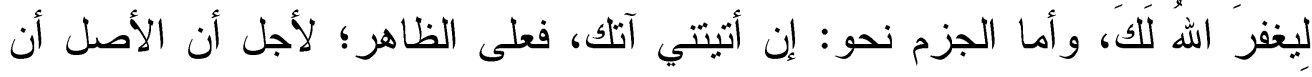
تجزم، و إنما لم يجزم الثرط؛ لامتتاع الثرط في الماضي... وكل واحدٍ من الوجهين

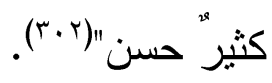




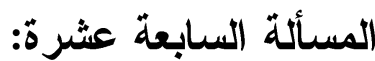

\section{علة افتقار القسم إلى الجواب:}

يعد القسم ضربا من التوكيد في الكلام، يذكر ليؤكَّد به خبر آخر (r.r)، فالقسم

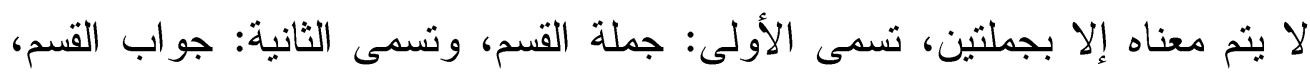

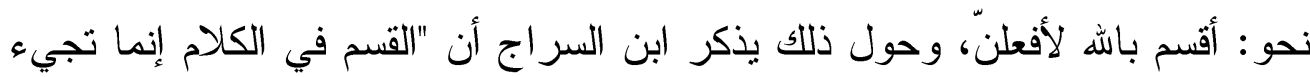

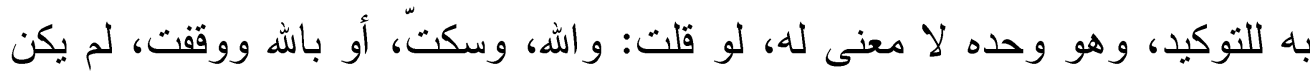

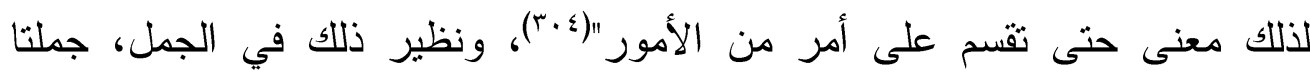
الثرط والجزاء، إذ جملة الشرط لا تقيد، ولا يتضح معناها إلا إذا انضمت إليها

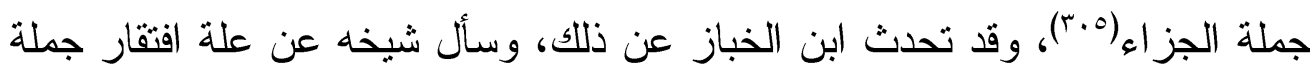

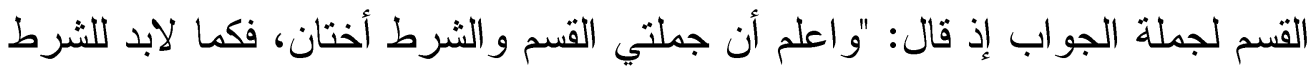
من الجزاء، كذللك لابد للقسم من الجواب، وسألت شيخنا رحمه الله لم افتقر القسم إلى

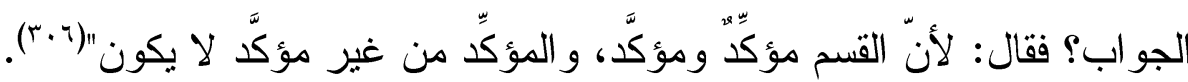
وبين الزمخشري أن الجملة "المؤكَّد بها هي القسم، والمؤكّدة هي القسم عليها، و الاسم الذي يلصق به القسم ليعظم به ويفخم هو المقسم به"(v•r)، فالقسم

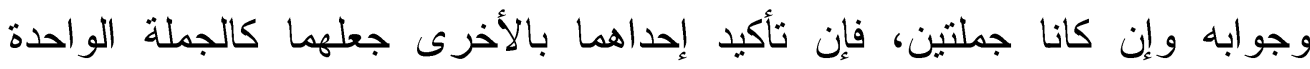

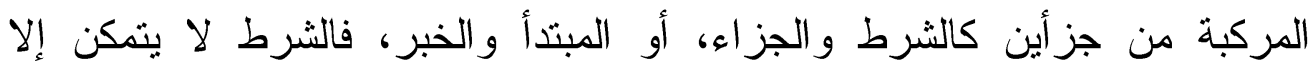

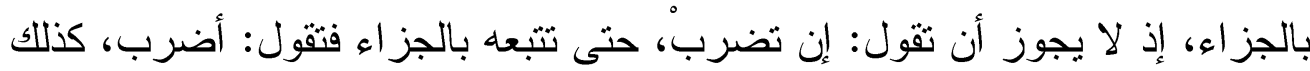

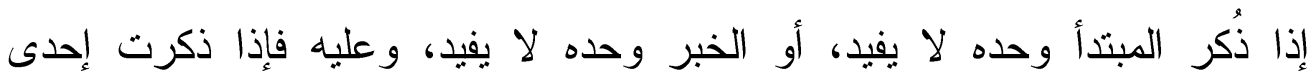
الجملتين دون الأخرى، فقلت: أحلف بالله، كان كقولك: (زيد) وحده في عدم الفائدة، حتى تقول: أحلف باله لأفعلن، أو زيدٌ منطلق، ونحو ذلك فتكتمل فائدة الكلام، ويتم

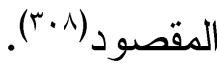

ووفقا لما تقدم، نجد أن ما ذكره النحاة يتفق مع جواب ابن مهران المثقدم. 


\section{المبحث الثاني: السؤالات الصرفية وجواباتها}

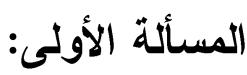

\section{علة الحكم بأن اللام ياء في قولهم: ذو مال:}

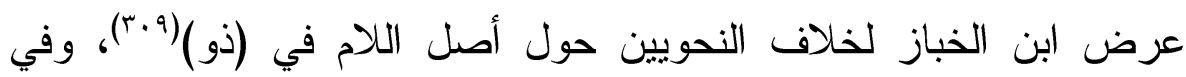
ضوء بيانه لهذا الخلاف سأل شيخه ابن مهران عن الرأي الذي ذهب أصحابه إلى إنى

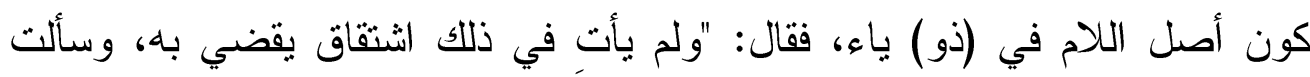

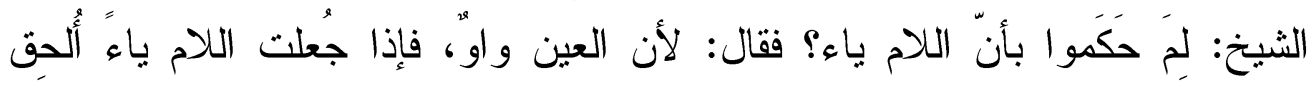
بالغالب، ولو جُعت و اوًا لألحق بالنادر؛ لأن ما عينه و او و لامه ياء، أكثر مدا عينه

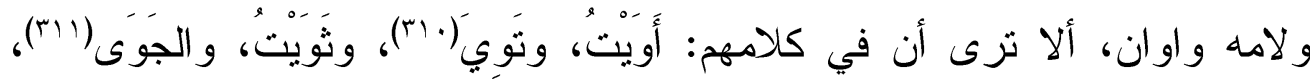

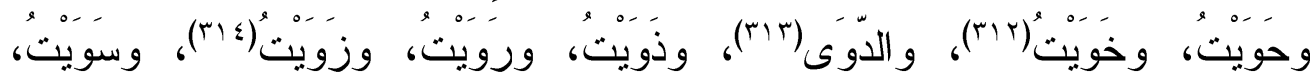

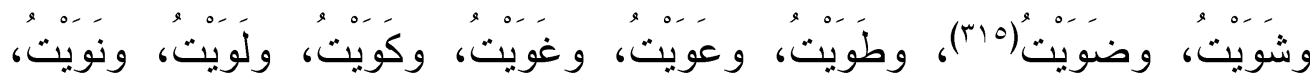

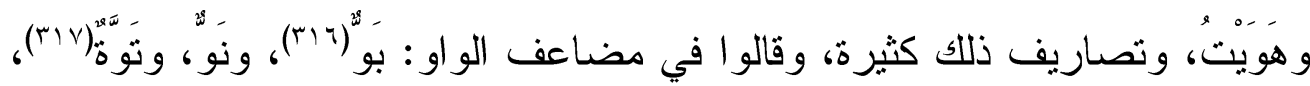

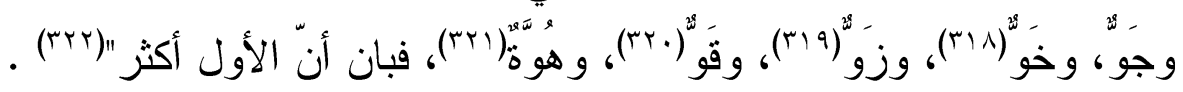
و عند مراجعة ما ذكره علماء اللغة والنحو والصرف ورو' حول هذه المسألة،

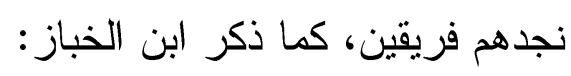

- الفريق الأول: ذهب أصحابه إلى أن أصل اللام في قولهم: (ذو مال) واو، و استدلو العى ذلك بأنه عند النسب إليها يتضح أصلها فيقال: ذوويّ، ومنهم

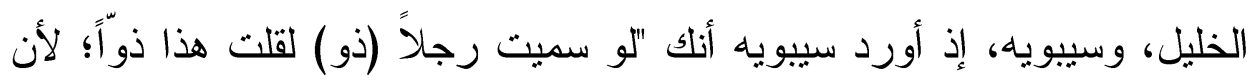

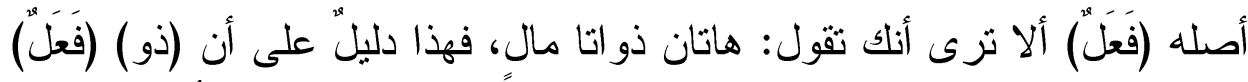

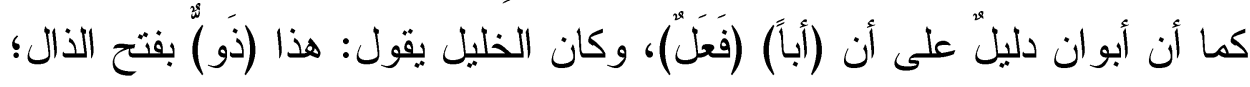

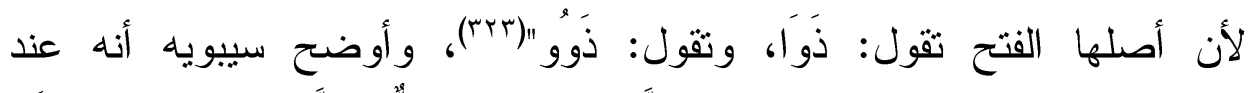

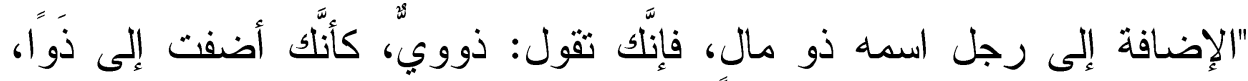

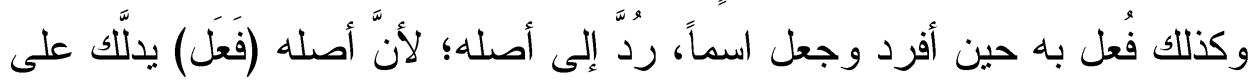

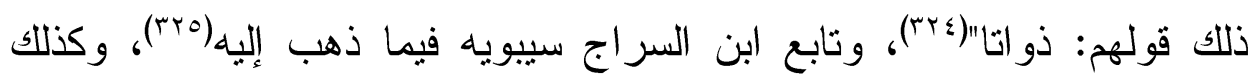


السير افي الذي بيّن أنك "إذا نسبت إلى رجل اسمه (ذو مال) قلت: ذوويّ، تردّ الذاهب؛ لأن (ذو) اسم على حرفين، الثاني من حروف المد واللين، ولا يقوم

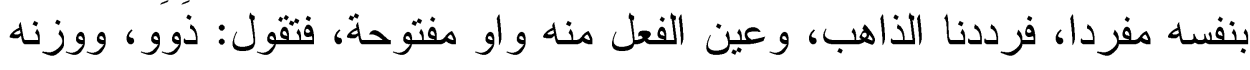

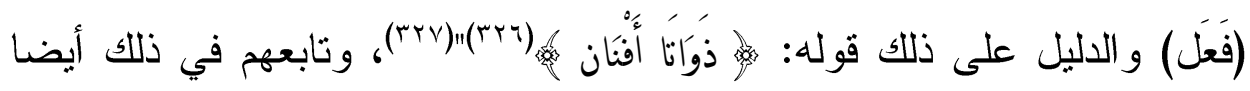
الجوهري، الذي أوضح أن "أصل (ذو) ذوَّ، منل عصنًا، يدل على ذلك قولهم:

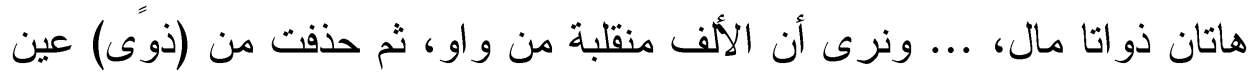

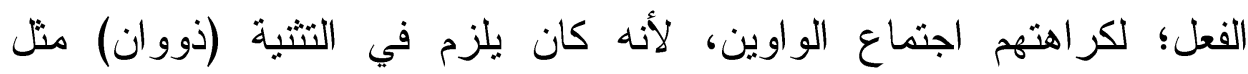

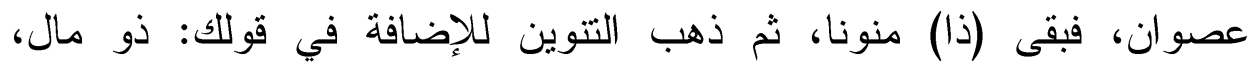
و الإضافة لازمة له، كما تقول: فو زيد، وفا زيد، فإذا أفردت قلت: هذا فم، فلو

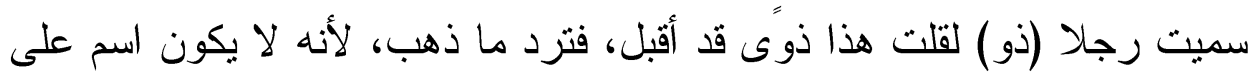

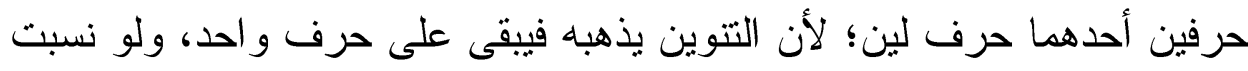

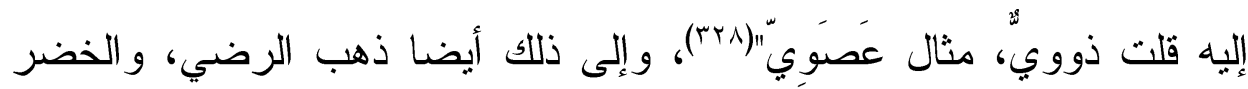

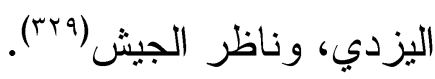

- الفريق الثاني: ذهب أصحابه إلى أن أصل اللام ياء، ومن أولئك الثمانيني الذي

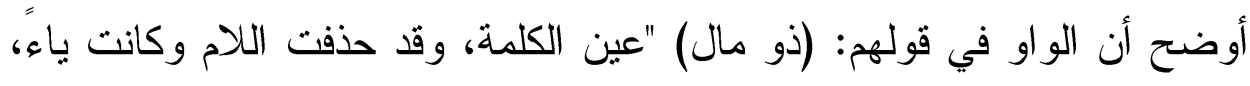

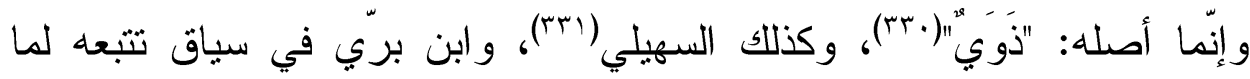
ورد عند الجوهري في الصحاح، فحين ذكر الجوهري أن الألف في (ذوا) منقلبة

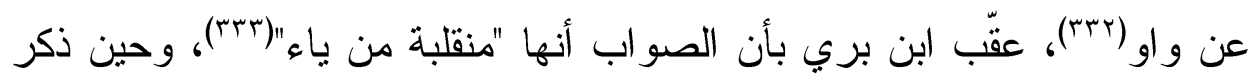

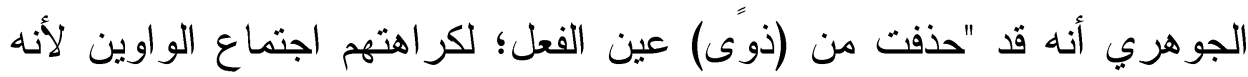

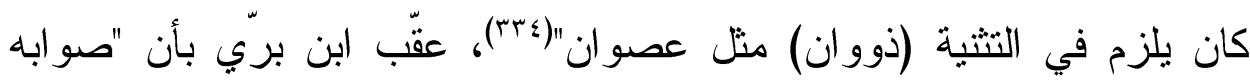

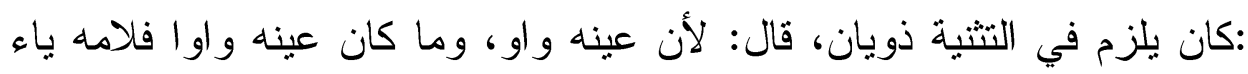

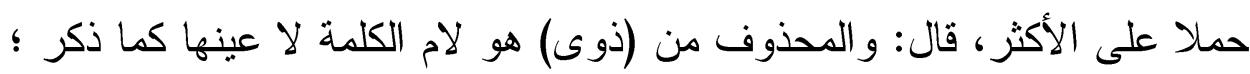

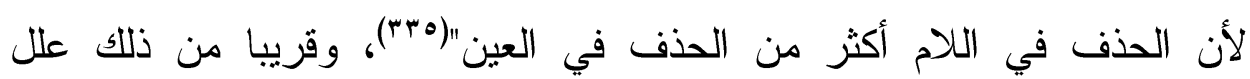


العكبري كون أصل اللام ياء بأن "باب طويتُ وشَوَتُ، أكثر من باب قُوة وحوةّ،

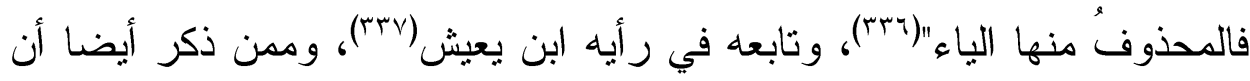

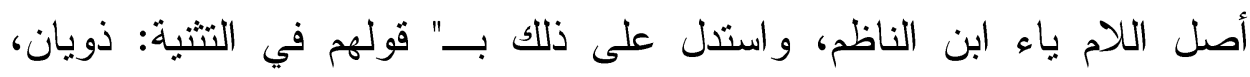
فحذفت الياء، وبقيت الواو حرف الإعراب، ثم ألزم الإضافة إلى اسم الجنس، لئه

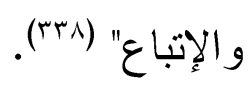

و هذا الرأي القائل أصحابه بأن أصل اللام في (ذو مال) ياء، هو الذي أخذ

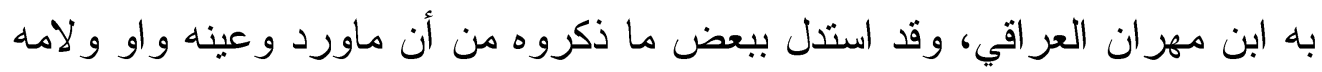
ياء، أكثر مما عينه ياء و لامه ياء، فهم بحملون ذلك ولك على الأكثر.

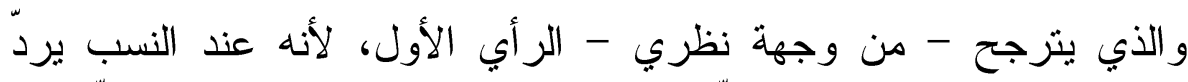

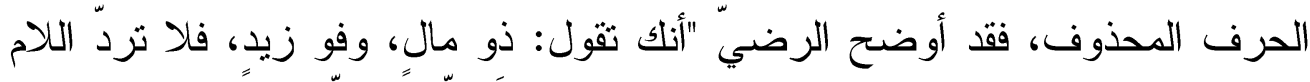

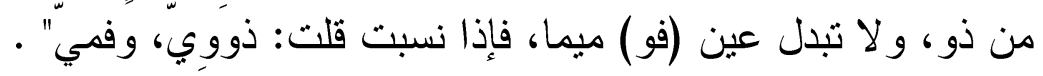
المسألة الثاتية:

\section{تثنية وجمع ما ختم بـ(ويه) نحو (عمرويه):}

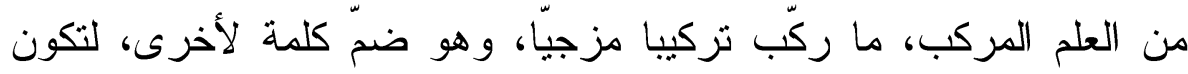

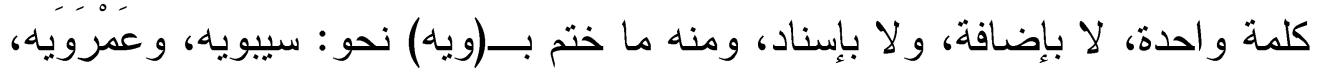
ونفطويه، وما أشبهها، وقد ذكر ابن الخباز أن من النحاة من يثنيّ (عمرويه)

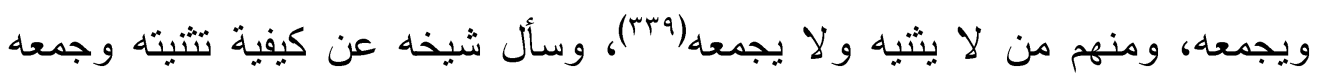
فقال: "فإن قلت: كيف أثثيه وأجمعه على هذا القول؛ قلت: سألت شيخنا رحمه اله وله عنه فقال: أقول: جاءني ذوا عمرويه، وذوو عمرويه، أي: صاحبا هذا الاسم، ولى

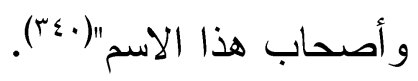

وقد اختلف النحاة حول إعراب ما ختم من الأعلام بــ(ويه) فمنهم من ذكر

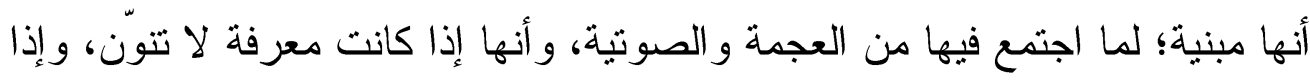

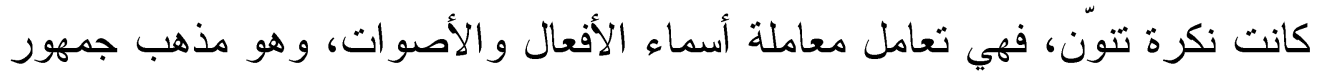

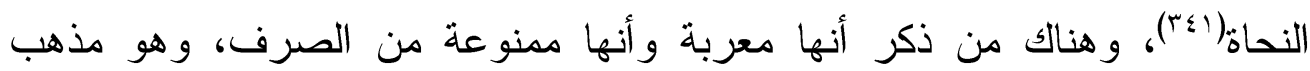




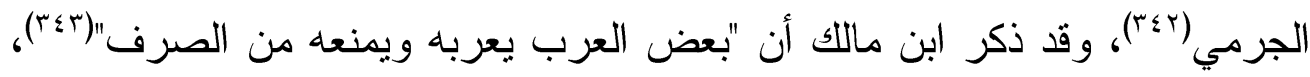
وعلّق أبو حيان على ما نُقل عن الجرمي بأنه إن "كان ما أجازه الجرمي مستنده

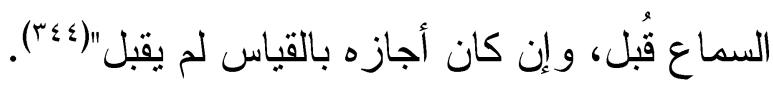

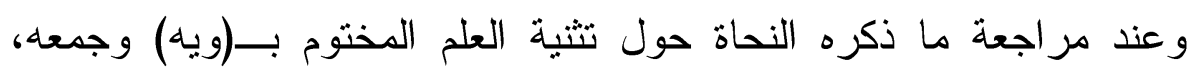

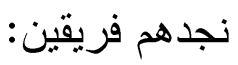
- الفريق الأول: ذهب إلى عدم جواز تثنيته وجمعه، ومن هؤلاء الزجاجي، الذي

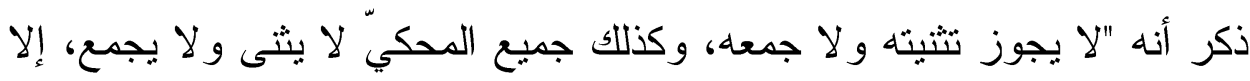

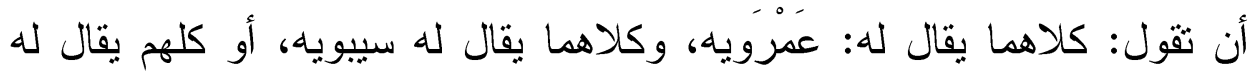

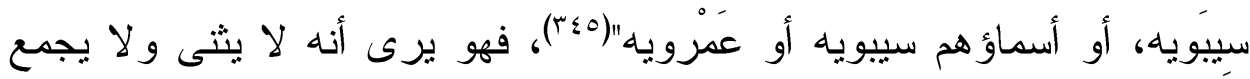

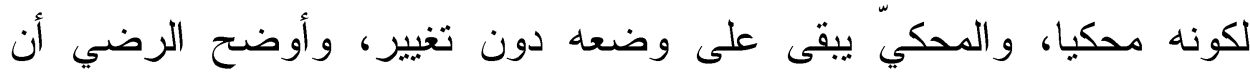

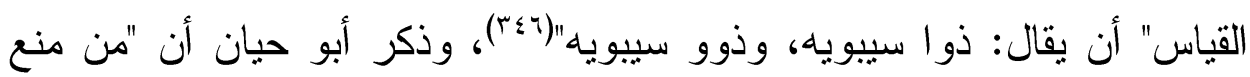

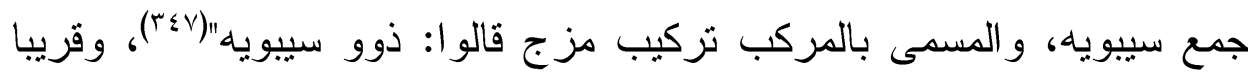
من ذلك بيّن ابن عقيل أنه عند تثنية أو جمع أحد هذه الأسماء، فإنه يضاف ولئ إليه ذو أو ذات، مثنى أو مجموعا "فتقول: جاعني ذو ا سيبويه، وللمؤنث: ذاتا سيبويه،

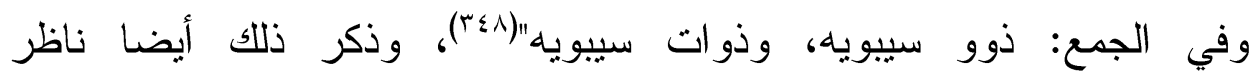

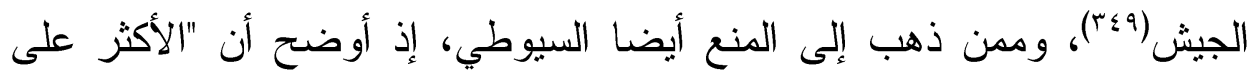

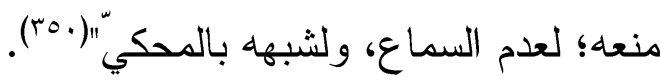
- الفريق الثاني: يرى أصحابه جواز تثنية وجمع ما ختم بـ(ويه)، فيقال:

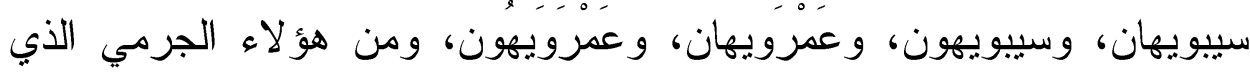

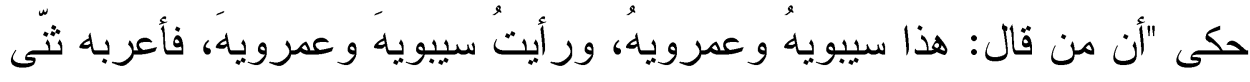

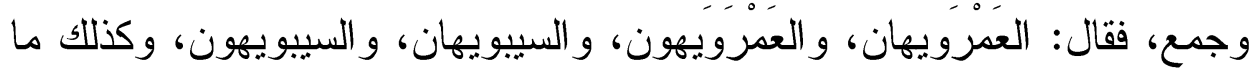
أشبهه"(101)، وذهب إلى الجواز أيضا المبرد، وبيّن أن الهاء في هذه الأعلام ليست للتأنيث، وأنها "تثىى وتجمع، فتقول فيه اسم رجل: عمرويهان، 
وعمرويهون"(ror)، وأجاز ذلك أيضا الثمانيني(ror)، ونقل السيوطي أن بعضهم

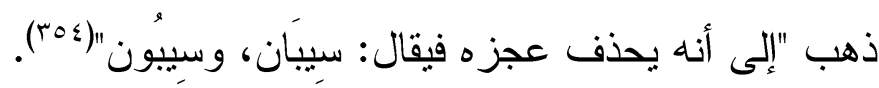

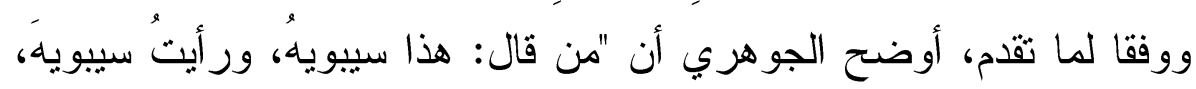

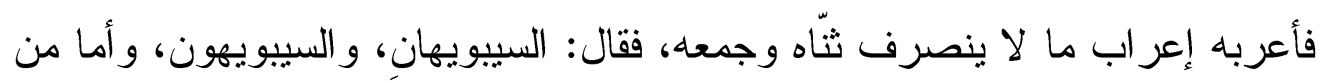

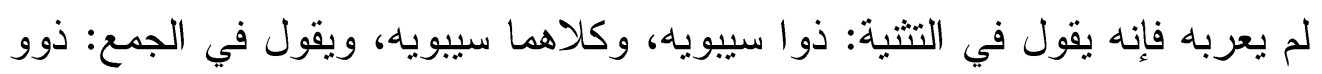

$$
\text { سيبويه، وكلهم سيبويه"(ro0). }
$$

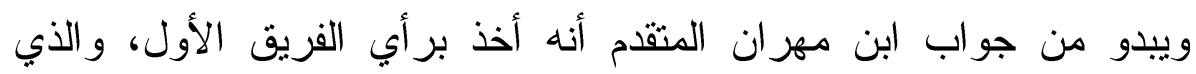

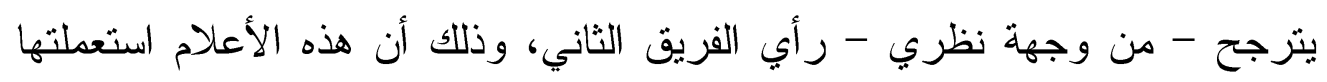

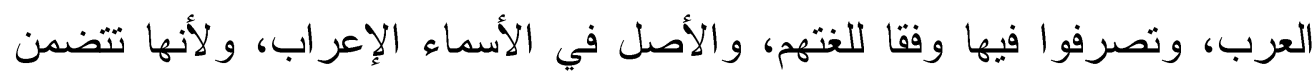

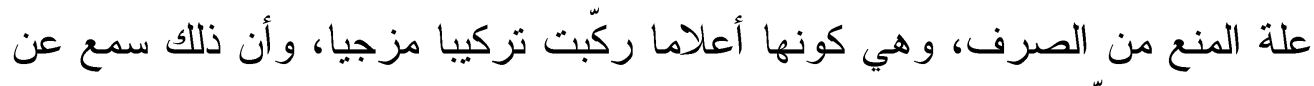

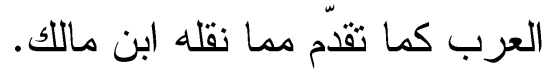

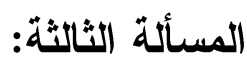

\section{علة عدم تصغير (عند):}

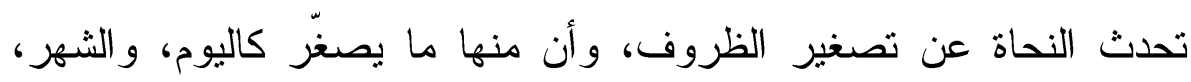

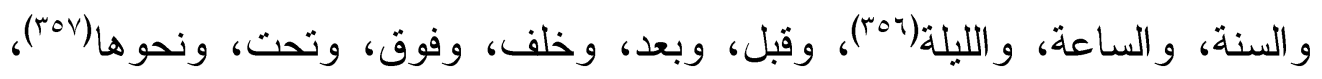

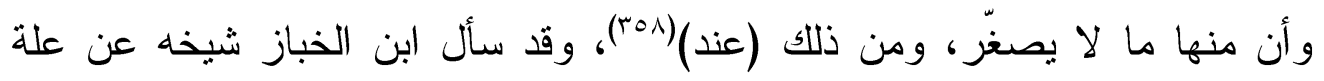

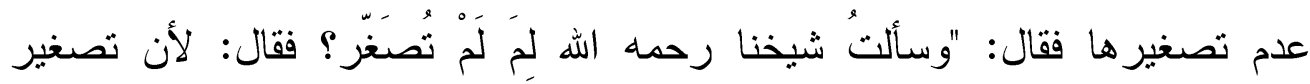

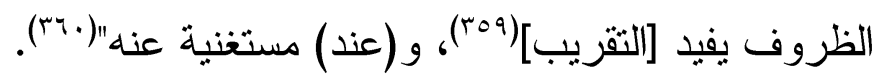

وعند مراجعة ما ذكره النحاة حول معنى (عند) نجدهم يذكرون أنها

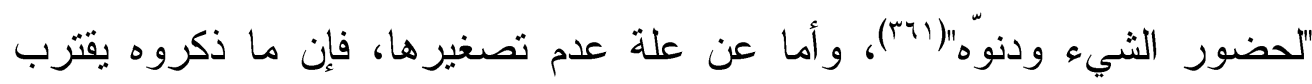

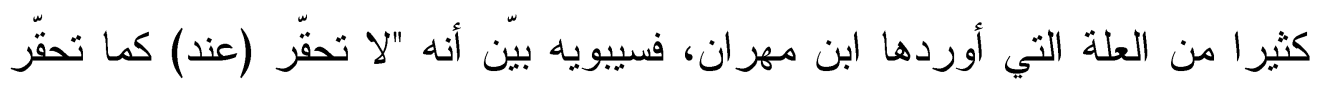

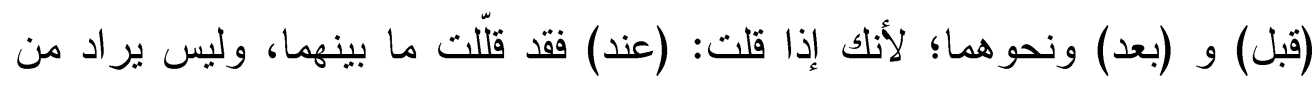

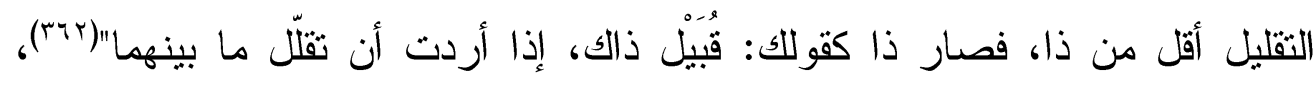

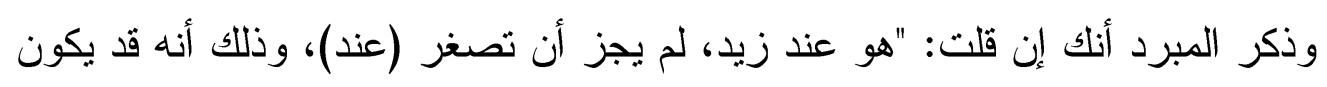

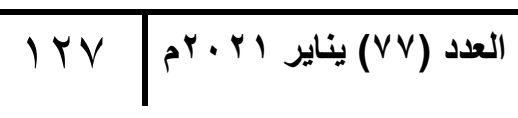


خلفه بكثير وبقليل، وكذلك (دونه) و (فوقه)، فإذا صغرتهما قلّلت المسافة بينهما، وإذا

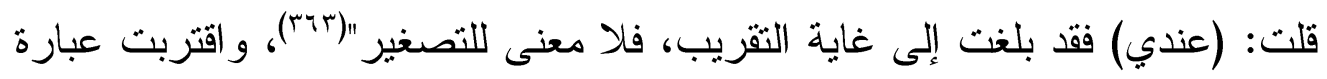
السير افي كثير ا مما أورده المبرد، إذ أوضح أنه "لا تصغر (عند)؛ لأن تصغير ها إنما

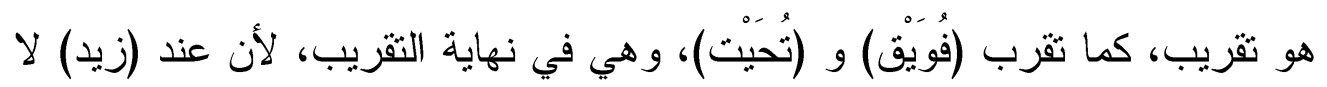

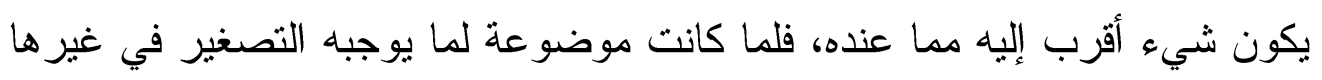

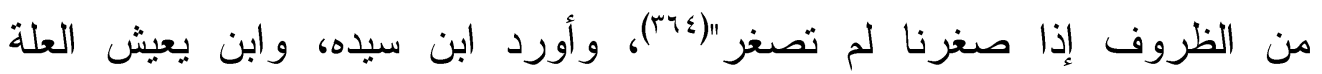
نفسها(rM0)، وكذلك الهرمي الذي بيّن أن (عند) معناها القرب، و التصغير معناه

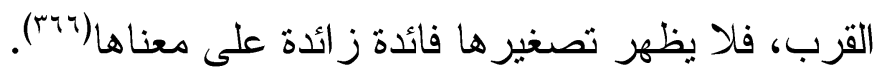
ومما ثقدم، نجد أن جواب ابن مهران قد اتفق مع ما ورد عن النحاة الذين تقدموا عليه، وو افقهم في ذلك من جاء بعدهم.

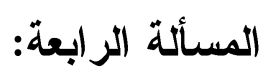

\section{علة عدم الاشتقاق من لفظ (الاثنين):}

من المسائل التي ناقشها ابن الخباز في باب العدد، مسألة عدم الاشتقاق من لفظ (اثثين) إذ ذكر "أن (الاثثين) هجر جانبه في موضعين، أحدهما: أن كسور

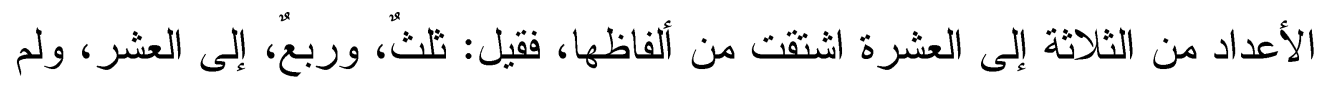

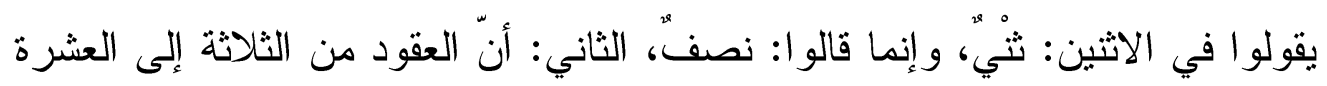

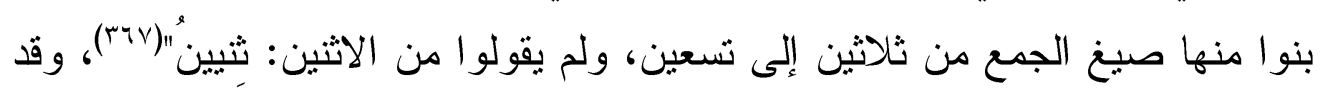

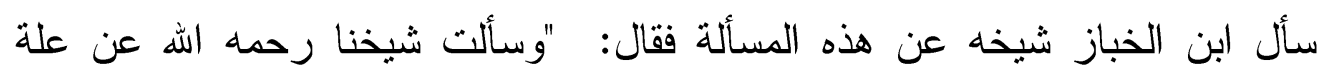

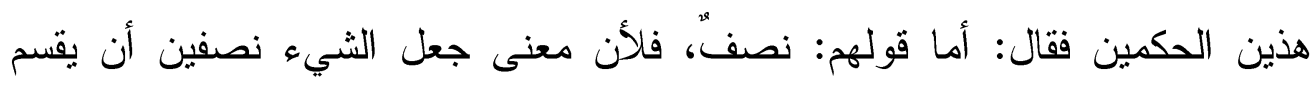
قسمين منساويين، فقيل لكل قسم: نصف، مأخوذ من النَّصَف بمعنى الإنصاف، و وأما

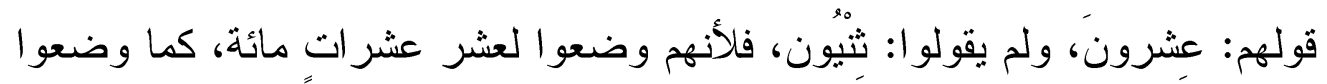

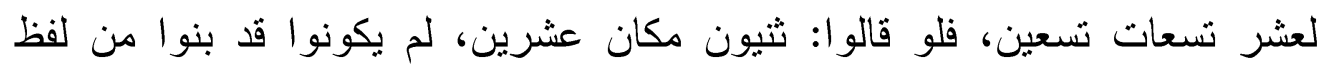

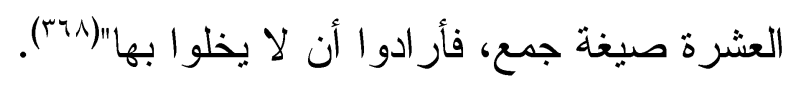


و عند مر اجعة ما ذكره النحاة حول هذين الحكمين، نجده على النحو الآتي:

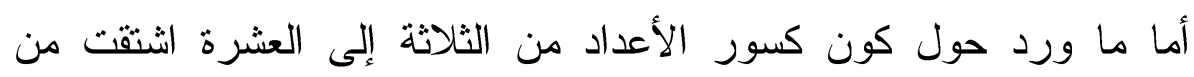

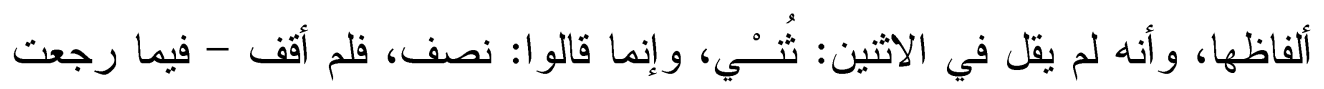
إليه من مصادر - على من علل هذا الحكم، سوى جو اب ابن مهر ان المتقدم.

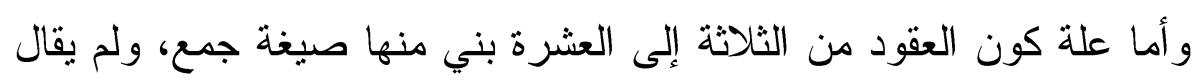

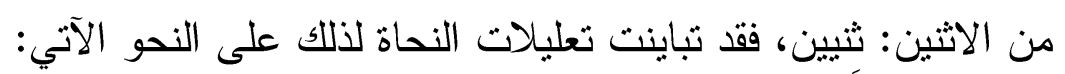

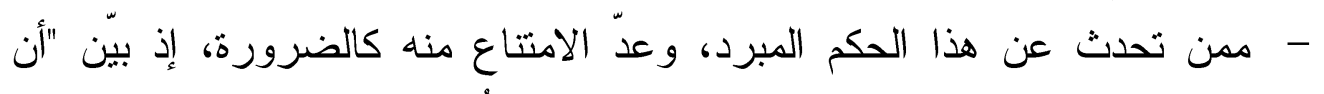

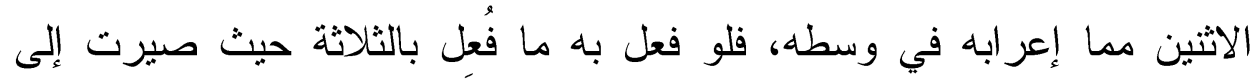

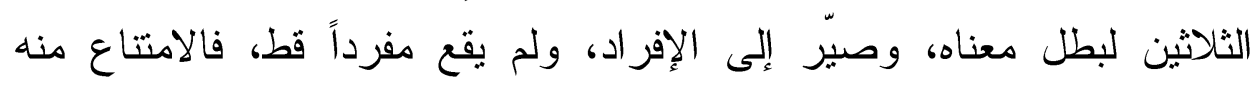
كالضرورة"(r79). - وبيّن السير افي علة ذلك عند حديثه عن كسر عين (عشرين)، إذ أوضح أنهم "

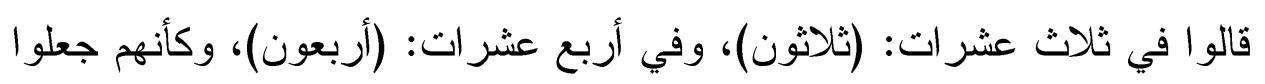

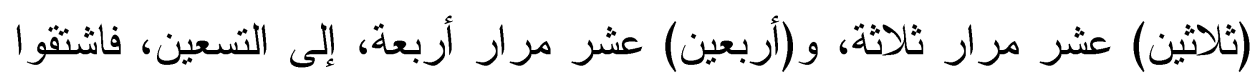
من لفظ الآحاد ما يكون لعشر مرار ذلك العدد، فكان قياس العشرين من الثلاثثن

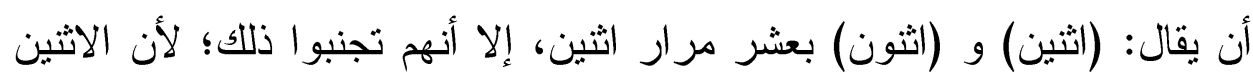

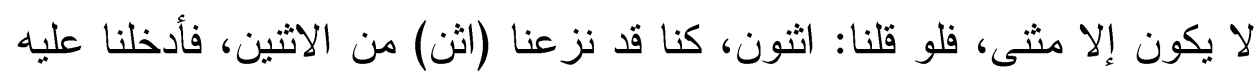

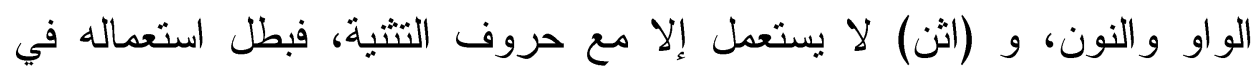

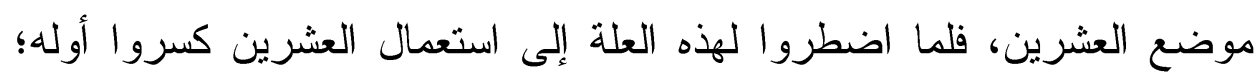

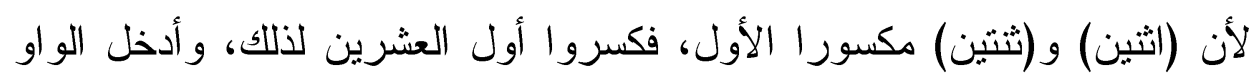

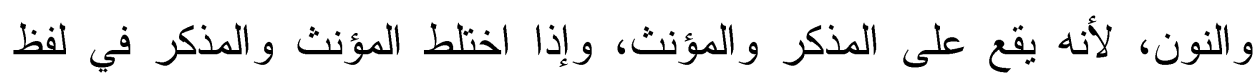

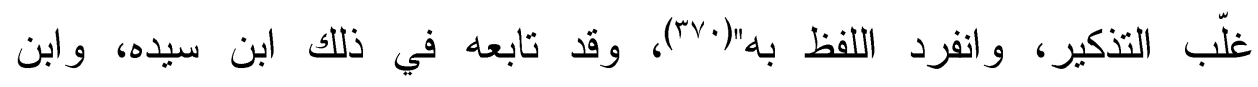
يعيش (rVI)

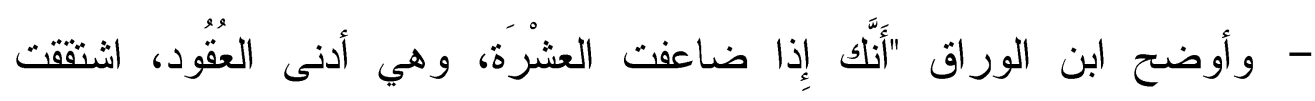

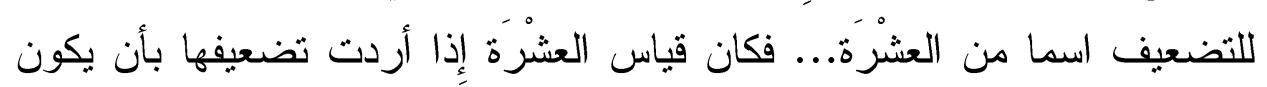




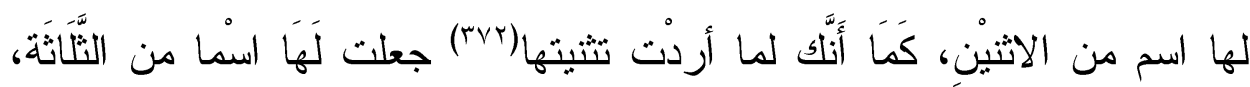

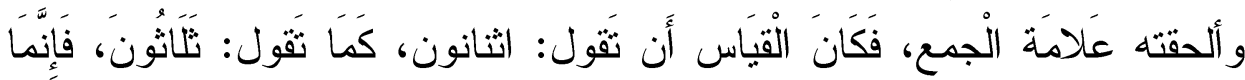

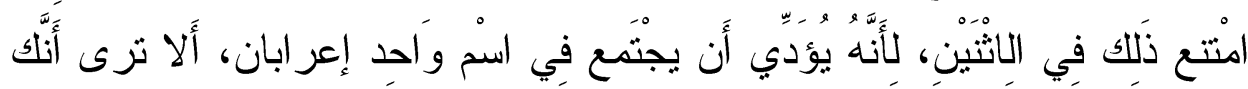

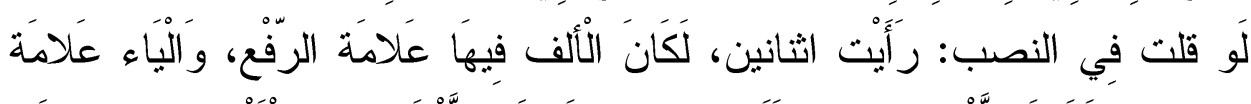

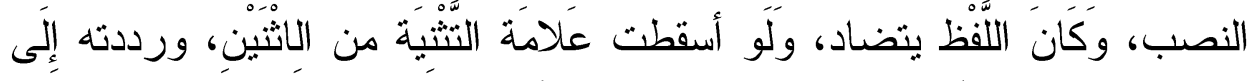

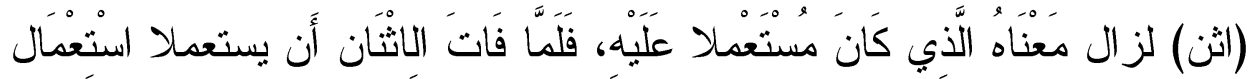

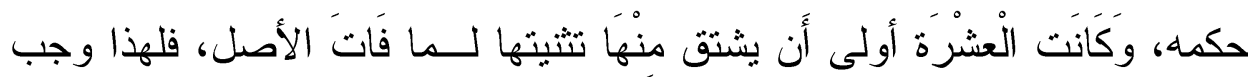

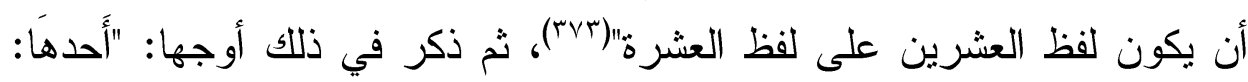

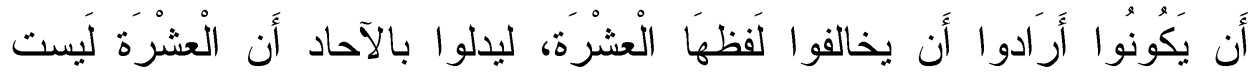

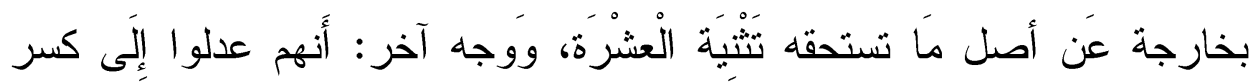

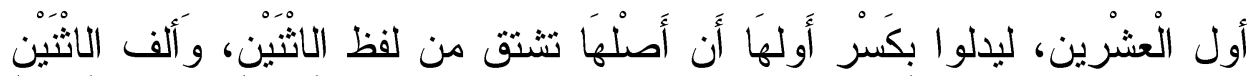

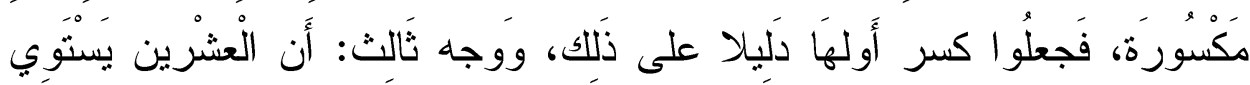

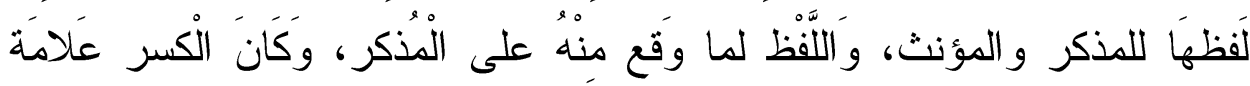

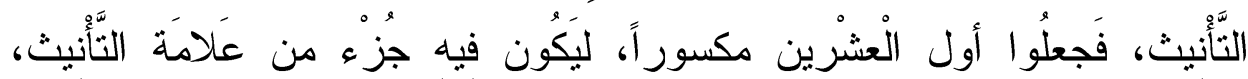

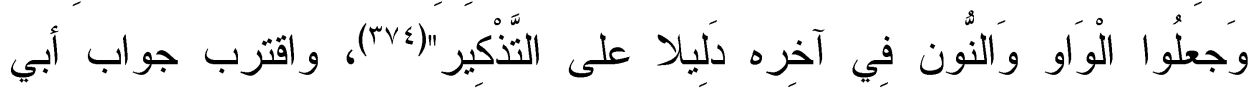

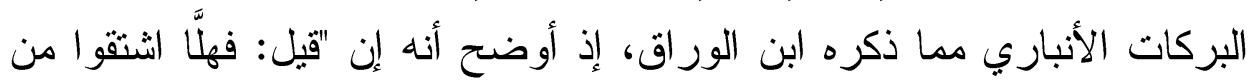

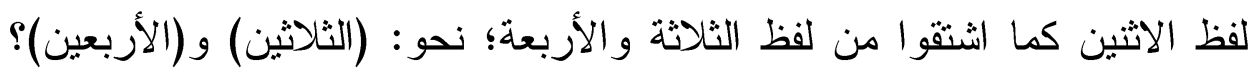

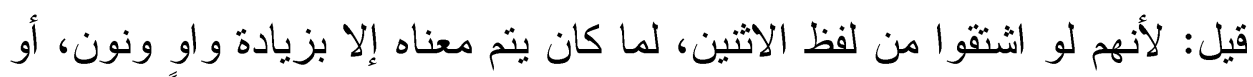

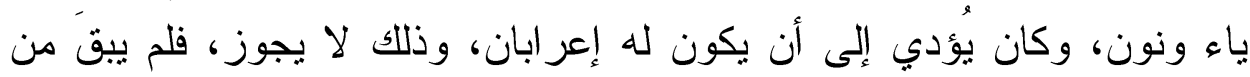

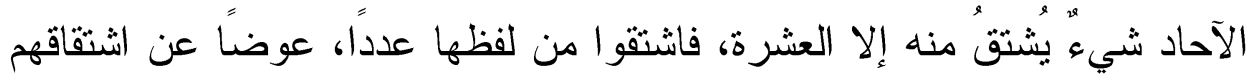

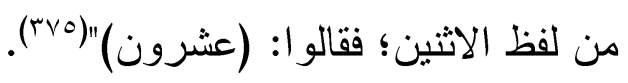

و لا بأس بالجمع بين كل ما تقدم في تعليل هذه المسألة، وتجدر الإشارة إلى أن السيوطي نقل قول ابن الخباز، وجعله من الفو ائد، لكنه لم يبين تعليل ابن مهران

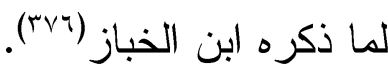


المسألة الخامسة:

\section{الاليل على أصالة الهمزة في (حنّاء) و (قثّاء):}

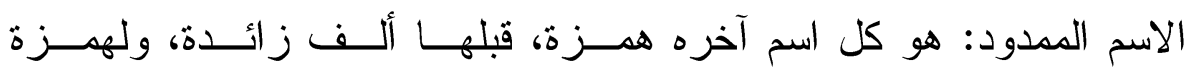

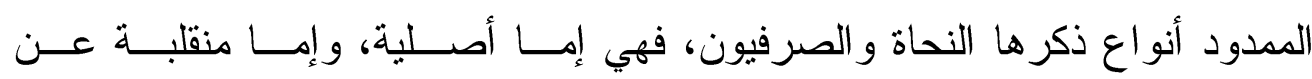

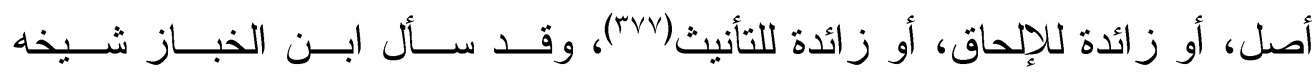

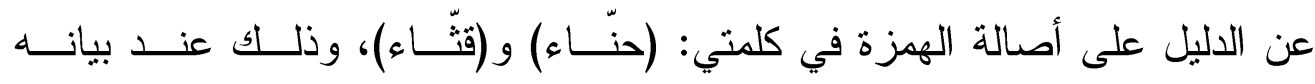

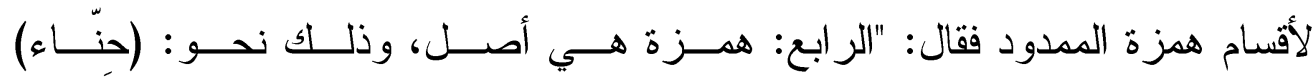

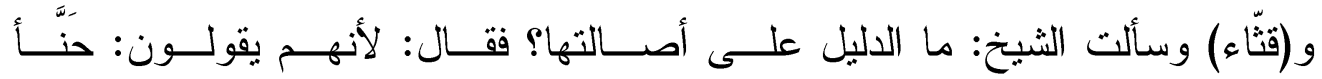

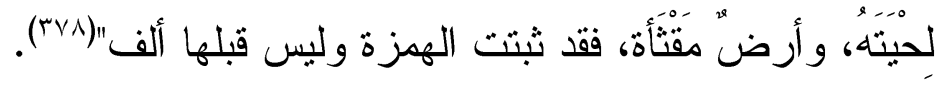

ويلاحظ في جواب ابن مهران المتقدم أنـــهـ أرجــع الكلمــة إلـى أصـــلها،

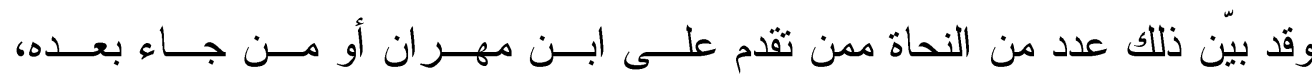

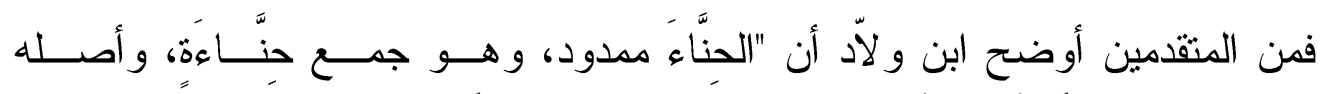

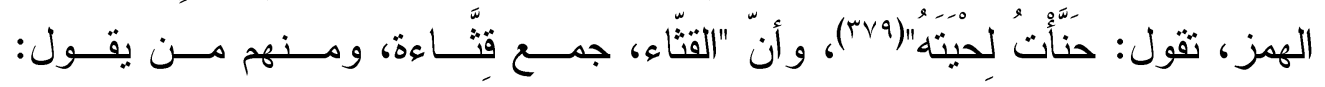

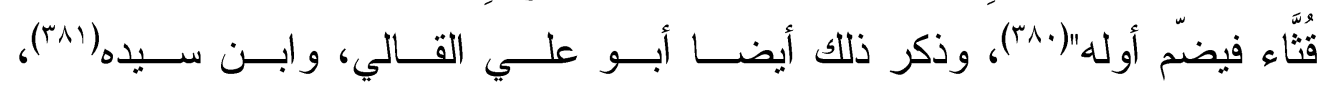

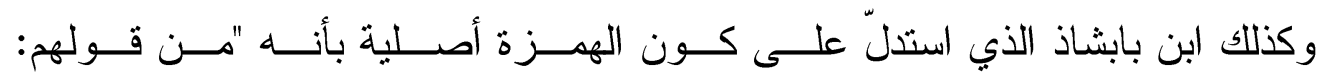

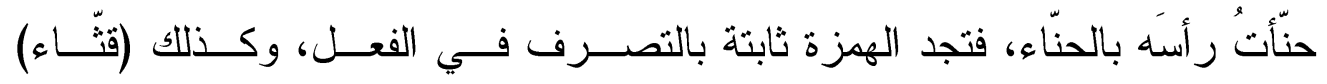

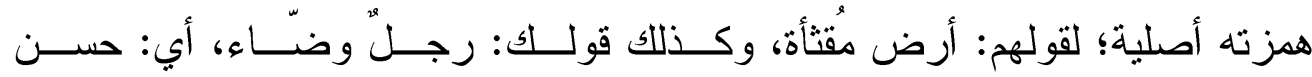

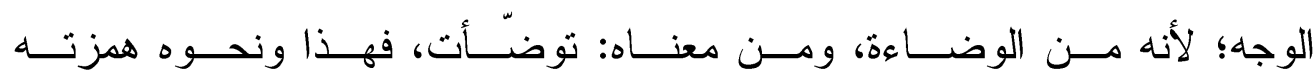

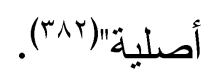

وممن استدل أيضـا على كون الهـــزة أصــلية بــالرجوع إلــى أصـــها،

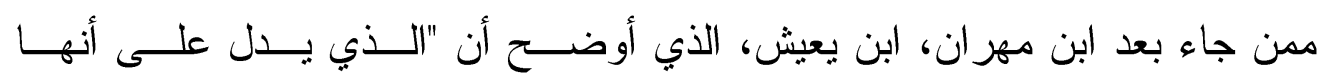

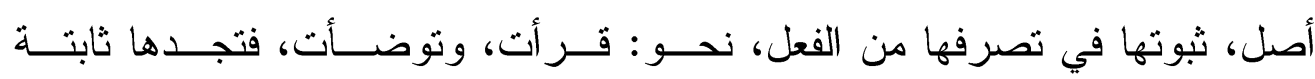

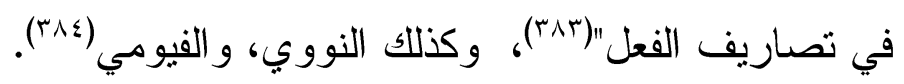




\section{المبحث الثالث: مصادر السؤالات المجموعة:}

اعتمدت في جمع سؤالات ابن الخبــاز لثــيخه ابــن مهــران العراقـي،

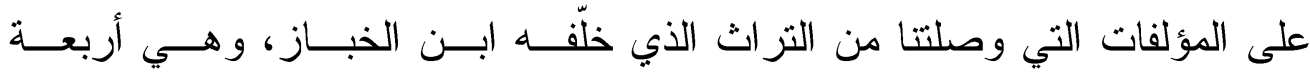
مؤلفات:

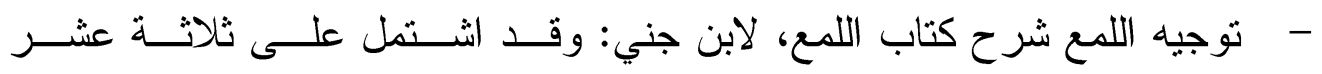
سؤ الا، عشرة منها نحوية، وثلاثة صرفية.

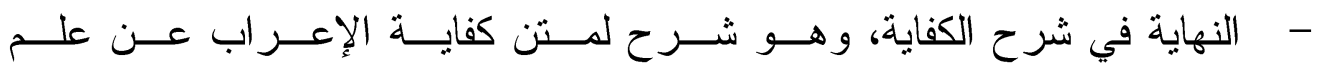

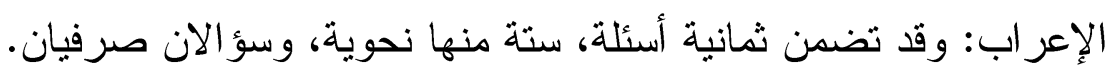

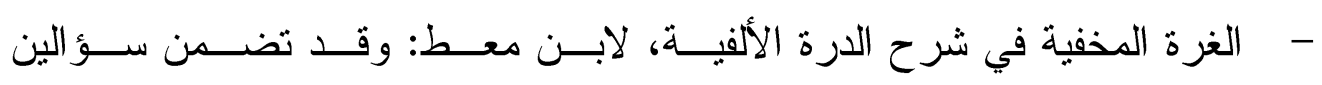

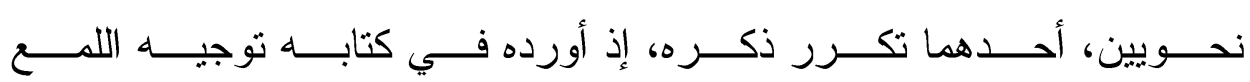

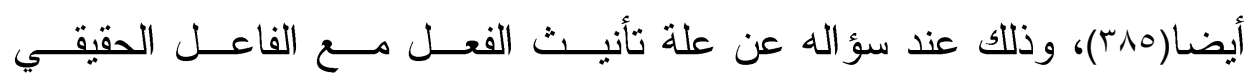

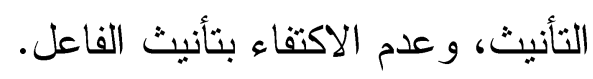
- - الفريدة في شرح القصيدة التي أنشأها ابن الــدهان فــي عـــيص الإعــراب،

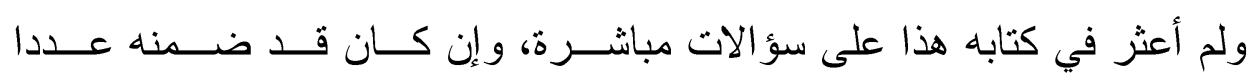

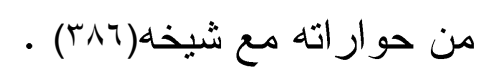

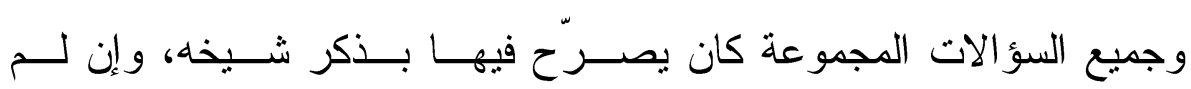
يذكر اسمه صر احة، كأن يقول: وسألت شيخا، أو وسألت الشيخ.

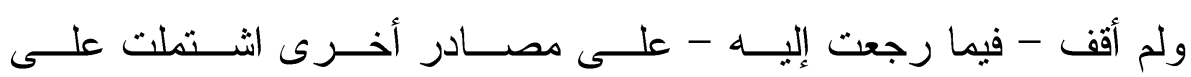

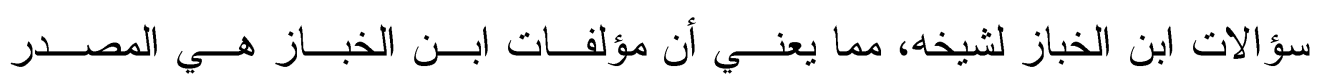

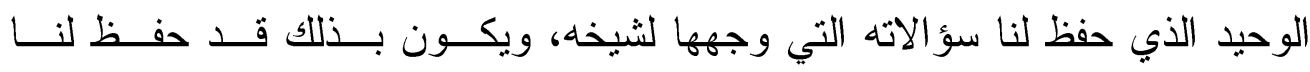

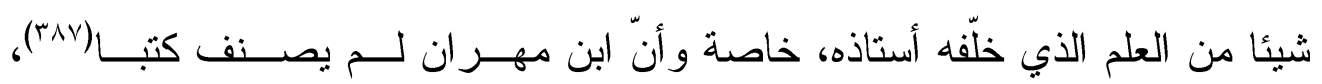
و إنما اكتفى بالتدريس في الحلقات. 


\section{المبحث الرابع: اتجاهات السؤالات النحوية والتصريفية وجواباتها}

من خلال ما ثقدمت دراسته من المسائل النحوية والتصريفية، نجد أن اتجاهات ثللك السؤالات وجو اباتها كانت على النحو الآتي:

أولا: اتجاهات السؤالات:

يمكن أن نجمل أهم اتجاهات سؤالات ابن الخباز لشيخه ابن مهران فيما يأتي:

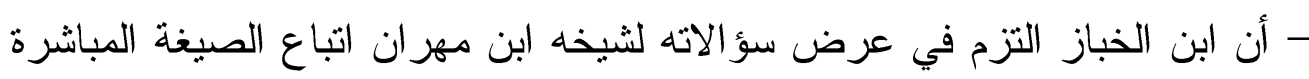

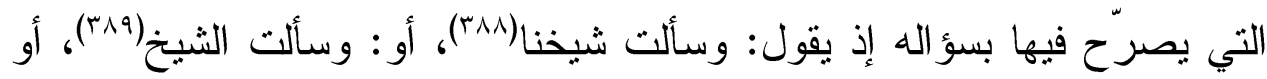

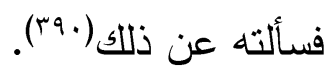

- أنه كان يستخدم أدوات الاستقهام ويتبع أسلوب التلطف عند سؤاله لشيخه، و لا عجب في ذللك، إذ هو أمر معهود في علاقة التلميذ بشيخه، ومن ذلك على سبيل

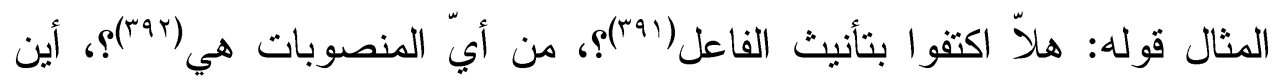

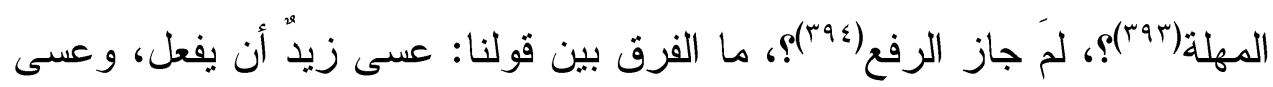

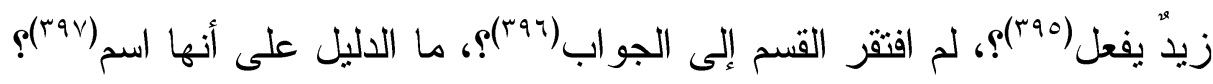

- ظهور الجانب العقلي بشكل واضح في سؤالات ابن الخباز لشيخه، إذ كانت

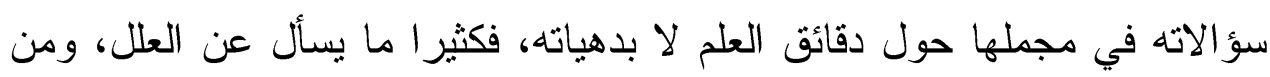
خلال استقر اء مؤلفات ابن الخباز، نلحظ عنايته ببيان العلل النحوية، فلا يكاد يبين عن مسألة إلا نجده مستكشفا لعلاها، وموضحا لأحكامها، فإذا أشكل عليه شيء منها سأل شيخه عنها، ومن ذلك مثنا سؤ اله عن علة تأنيث الفعل مع الفاعل

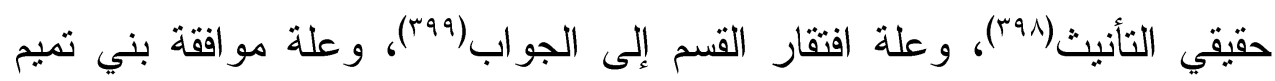

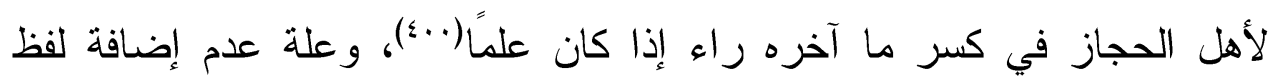

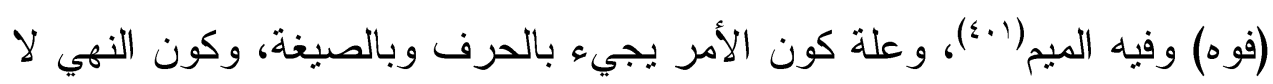

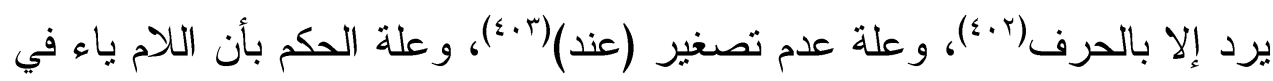

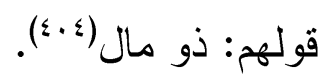


- غلب على أسلوب ابن الخباز الاكتفاء بعرضه لسؤاله لشيخه حول الدسألة، وجو ابه عنها، ثم يستطرد في عرض المسائل المتعلقة بالباب، إلا أننا نجده أحيانا يشرح شيئا من جوابات شيخه وييدي مو افقته لها، ومن ذلك مثنلا أنه عند سؤ اله

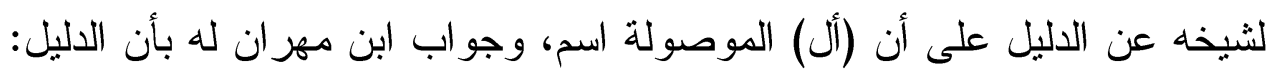

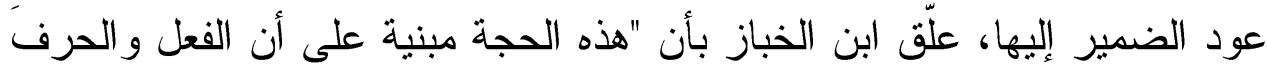

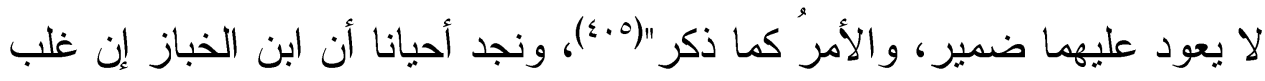

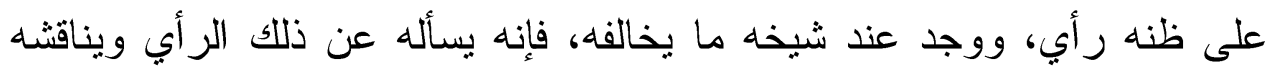
فيه، وقد تبين ذلك عند سؤاله عن دلالة (قد) عند دخولها على الفعل

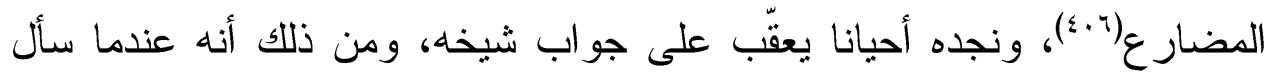

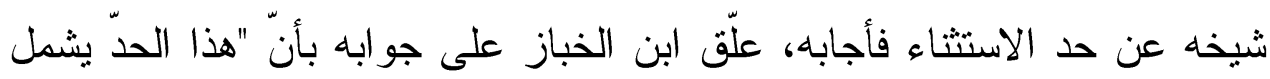

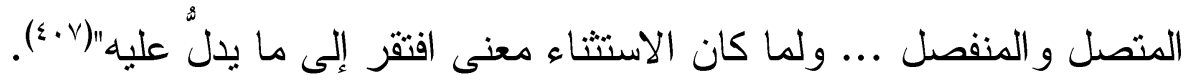

- تتوعت سؤالات ابن الخباز التي وجهها إلى شيخه، فمنها ما هو سؤال عن حكم

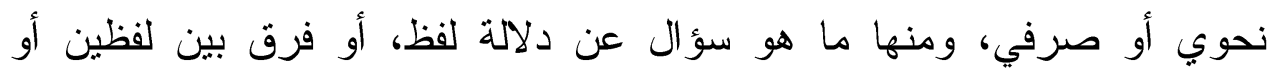

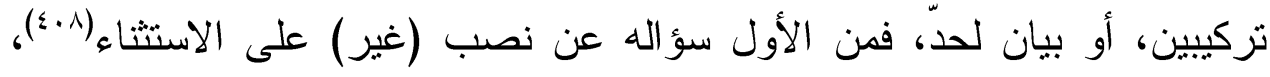

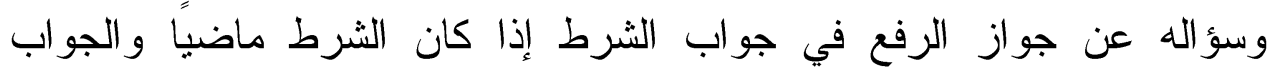

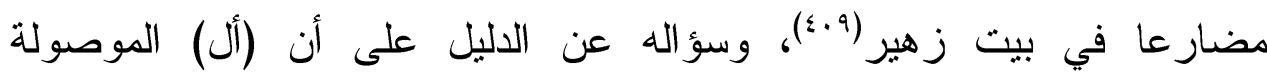

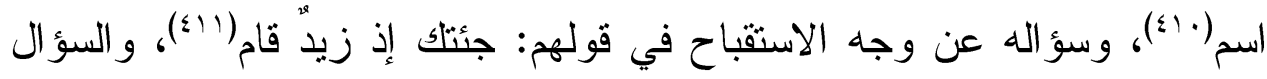

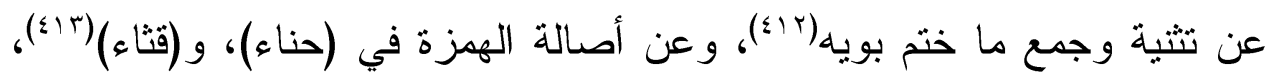

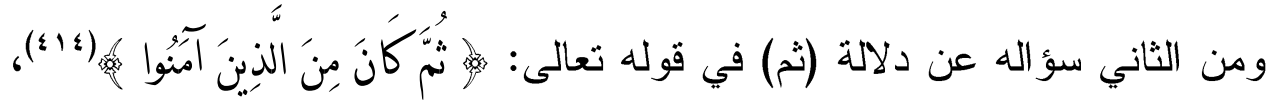

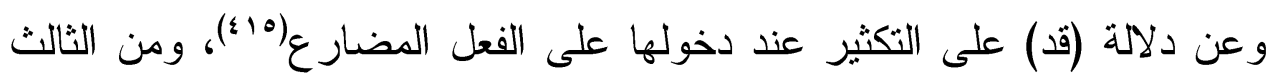

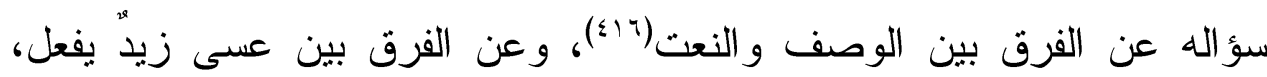

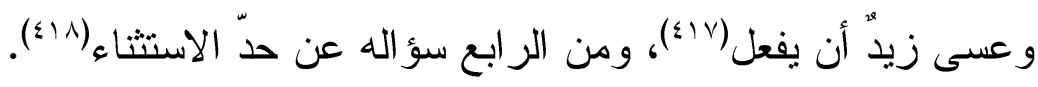


يمكن إجمال اتجاهات جوابات ابن مهران لتلميذه ابن الخباز فيما يأتي:

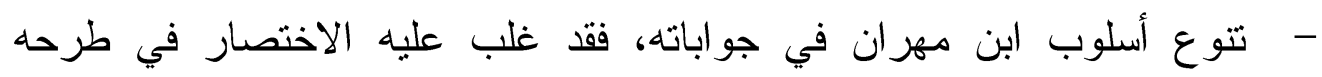

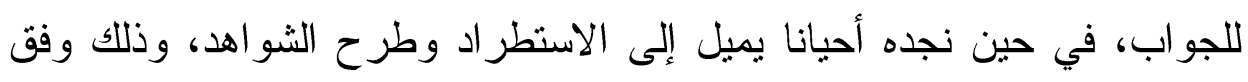
ما تقتضيه المسألة، فمن الاختصار قوله عندما سأله ابن الخباز عن دلالة (ث)

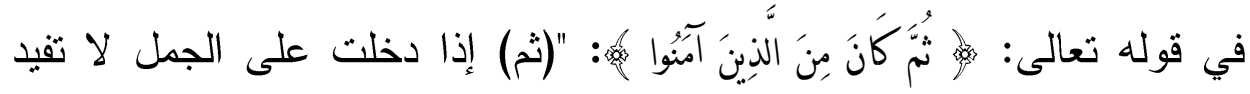
التزتيب"(9)؛، و عند سؤاله عن جواز الرفع في جواب الشرط إذا كان الثرط

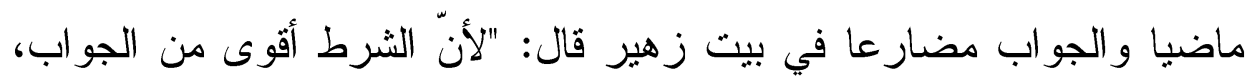

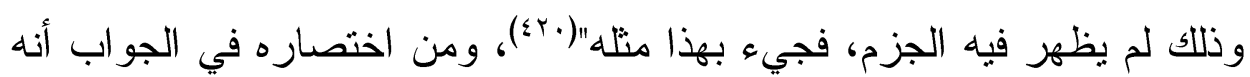

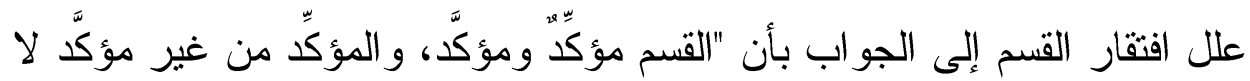

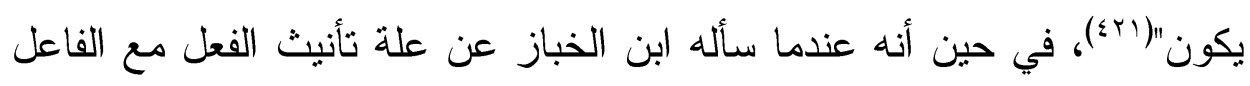
الحقيقي التأنيث، وعدم الاكتفاء بتأنيث الفاعل، أورد شواهد من الشعر العربي لبدلل بها على ما ذكره في جوابه(rr\&)، كما ظهر الاستطر اد عند بيانه للفرق

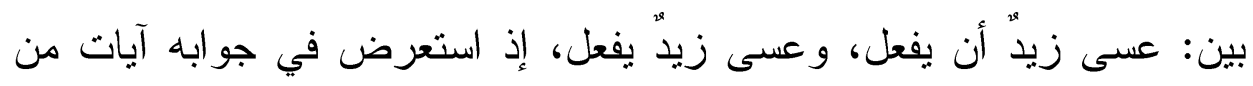
القرآن الكريم، وقارن فيها بين التركيبين، وبيّن الفرق بينهما من حيث الدين الالة،

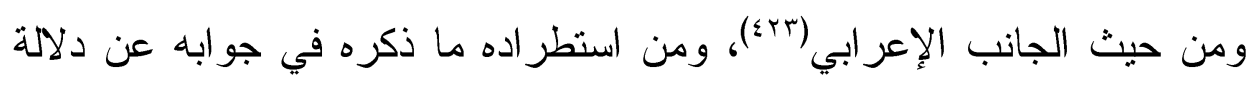

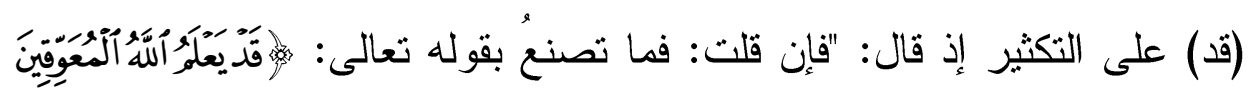

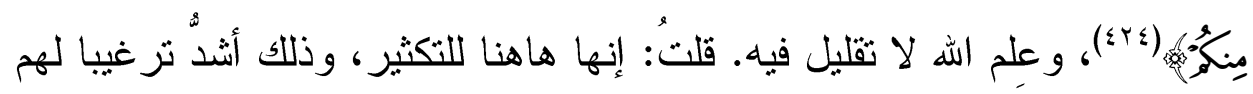
وتخويفا، و لا يبعد أن يكون الحرف دالا على معنيين، وإذا اختلفا فلا عليك

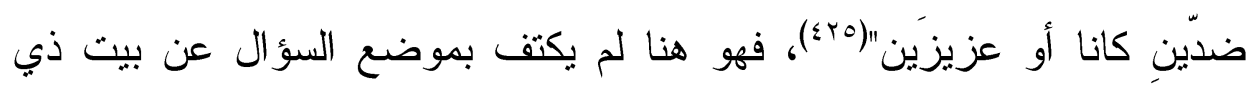
الرمة، وإنما أورد شاهدا آخر من القرآن الكريم ليدلل به على لـى المسألة.

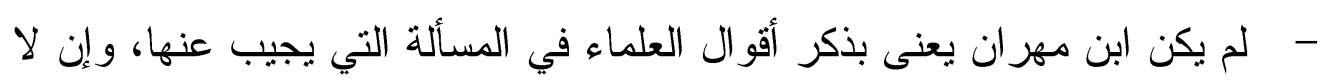
حظنا في بعض أجوبته أنها ثقترب مما ورد عند غيره من المثقدين، ففي 
جوابه عن علة تأنيث الفعل مع الفاعل الحقيقي التأنيث، وعدم الاكتفاء بتأنيث

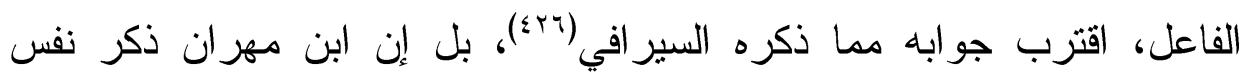
الأبيات التي أوردها السيرافي، وجعلها دليلا على جوابه، وفي التقريق بين

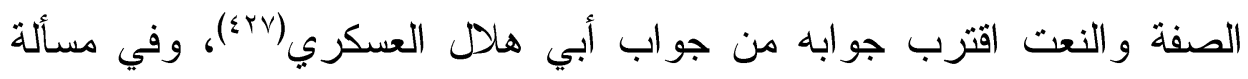

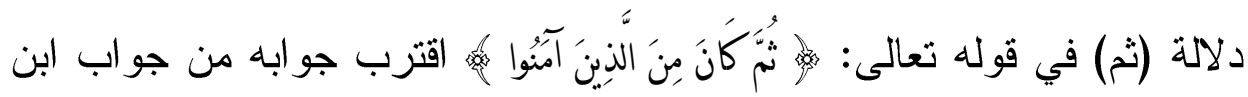
الأثير(^^^)، كما اقترب جو ابه من جواب ابن و لاد وابن بابشاذ عندما سأله ابن

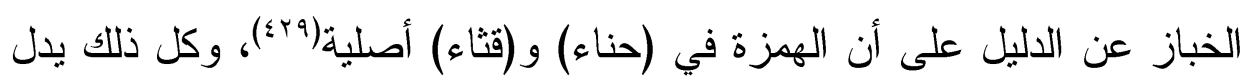
على سعة اطلاع ابن مهران على كتب من تقدمه، و إفادته مما ورد لايهه، و إن ولن لم يكن بعنى بنسبة الآراء إليهم.

- - ظهر من خلال أجوبة ابن مهر ان ما يتمتع به من سرعة البديهة، و الملكة اللغوية التي يتمتع بها، و اطلاعه على كثير من العلوم، حتى في المسائل التي لم يسبق به هن

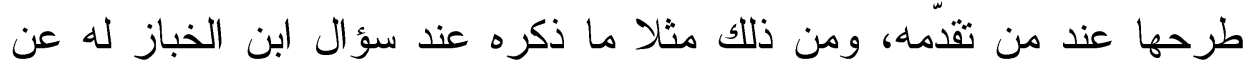

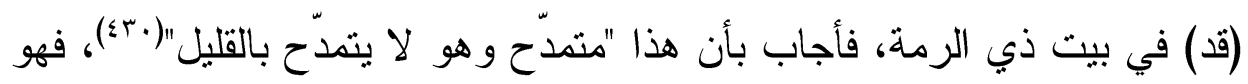
في جوابه هنا ير اعي المعنى العام، و السياق الذي وردت فيه (قد)، ولم يعتمد

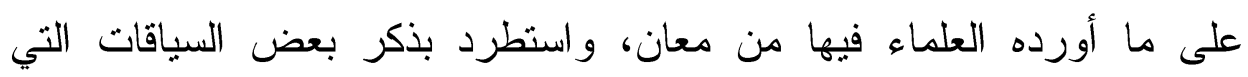
تخالف بعض ما ذُكر في معناها؛ ليبر هن على صحة ما ذهب إليه، و عندما سأله

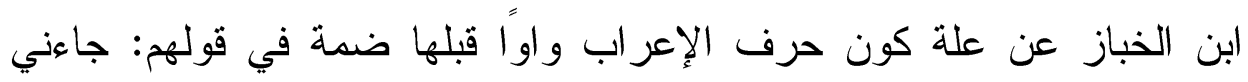

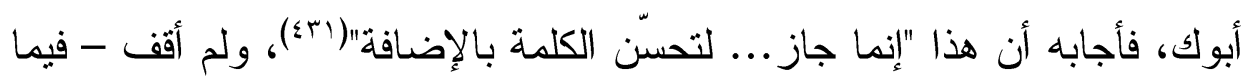

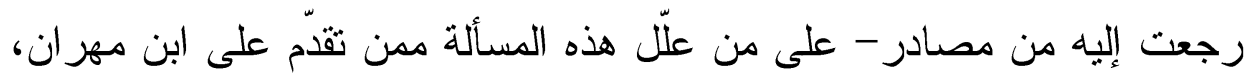

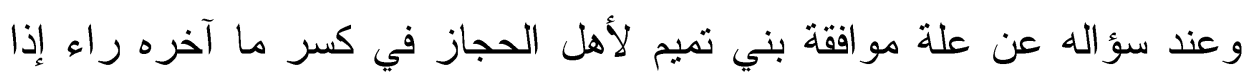

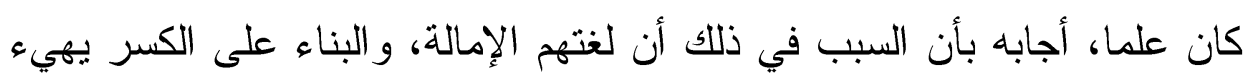

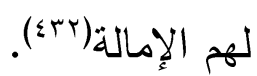
وكل ذلك يدل على سعة معرفة ابن مهران واطلاعه على العلوم. 


\section{البحث الخامس: منزلة السؤالات في التراث النحوي}

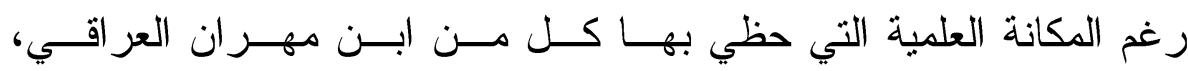

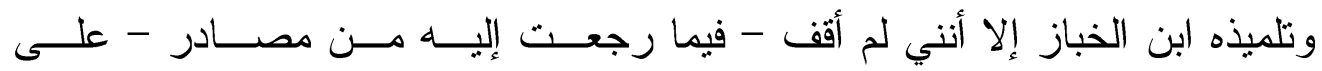

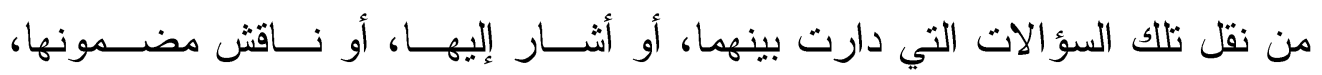

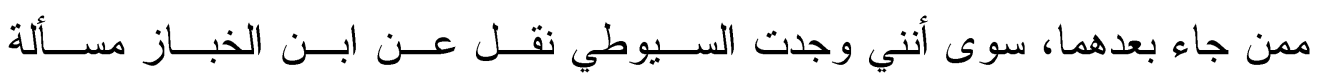

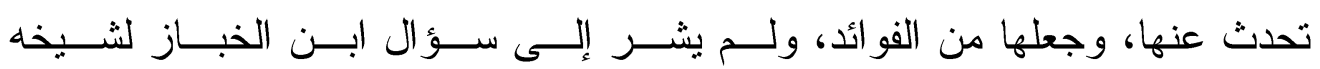

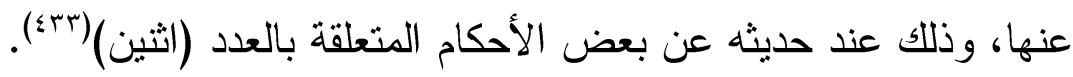

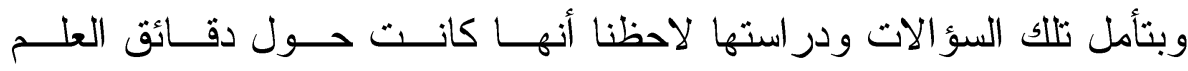
لا بدهياته، ويمكن تصنيفها وفقا لموقف العلماء منها إلى ما يأتي: 1- سؤالات حول مسائل تعد موضع اتفاق بــين النحــاة و الصــرفيين، كالســـؤال

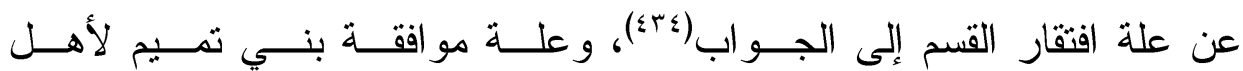

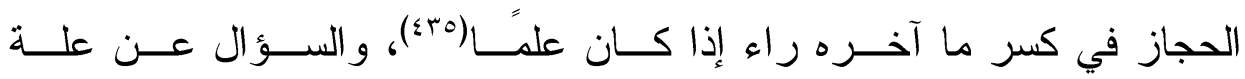

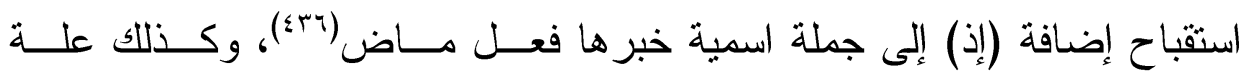

$$
\text { عدم تصغير (عند)( }
$$

Y- سؤالات حول مسائل تعد موضع خــلاف بــين النحــاة و الصــرفيين، ومــن

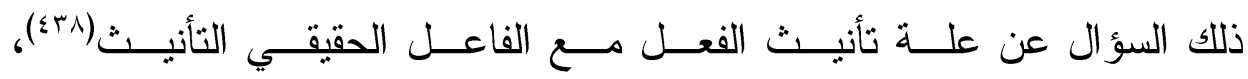

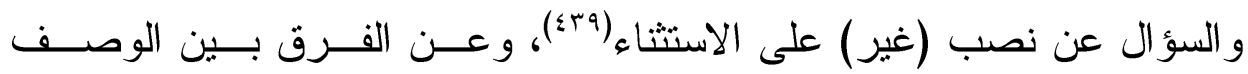

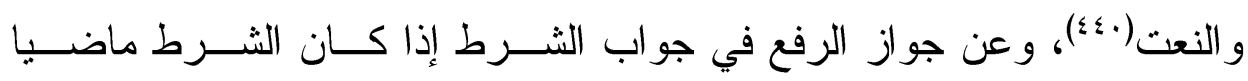

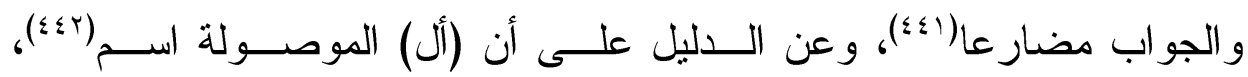

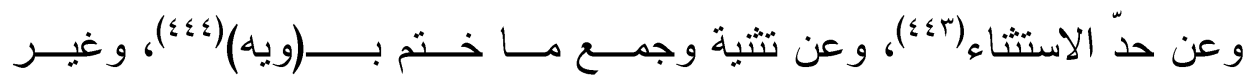
ذلك.

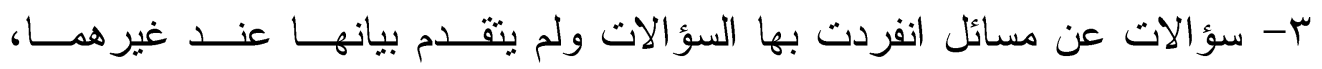

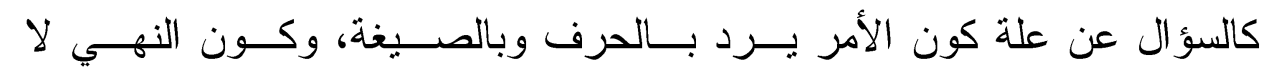




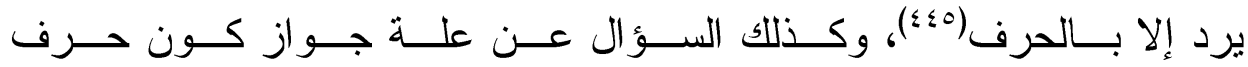

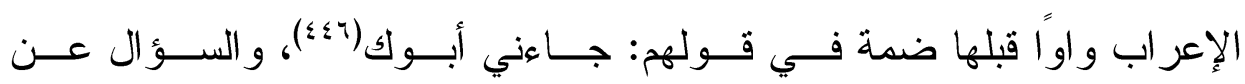

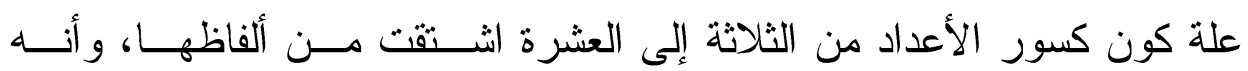

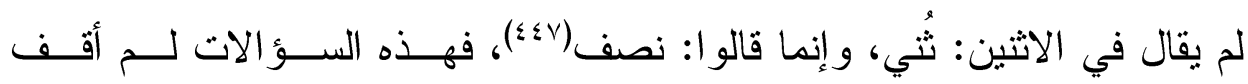

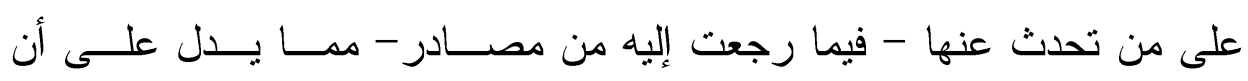
لهذه السؤالات أثرًا في الكثف عن عل علل جديدة، و التعمق في در استها.

\section{الخاتمة}

بعد اســتـعر اض ســؤالات ابــن الخبــاز لثـــيخه ابــن مهــر ان العر اقـي ودر استها وتحليلها، نخلص للنتائج الآتية:

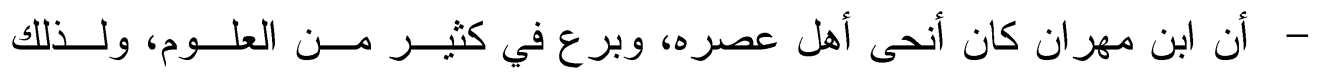

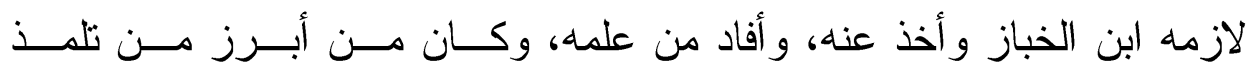

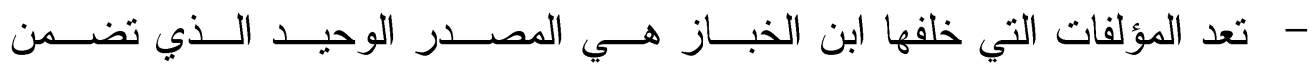

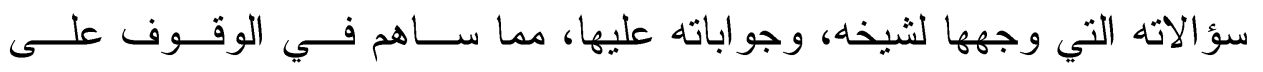
شيء من علم ابن مهر ان و آر ائه، وفكره النحوي. لهو النه

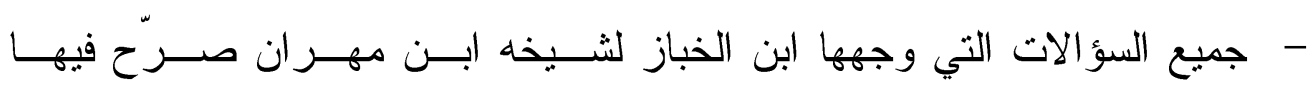

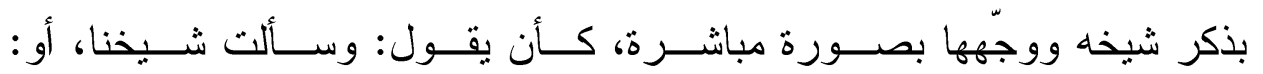

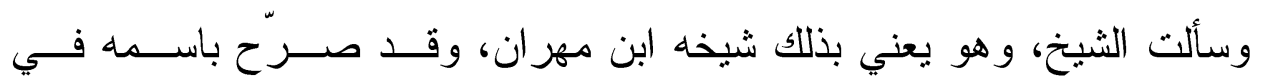

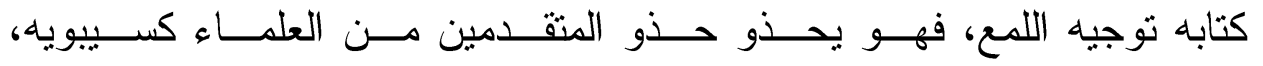
و الفارسي، و ابن جني عند إسنادهم لشيوخهم.

- تتوعت السؤالات التي وجهها ابن الخبــاز إلــى شــــخه مـــابين ســـؤال عــن

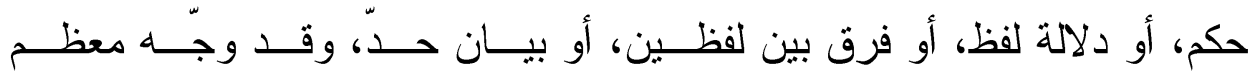




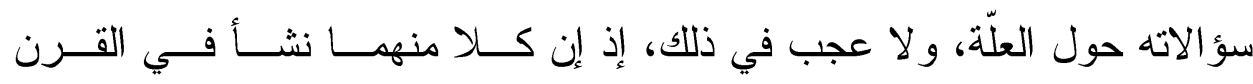
السابع، الذي شهد جذوة الاهتمام بــالتفكير النحــوي، وبـــرزت فيـــه العنايــة بدر اسة العلل.

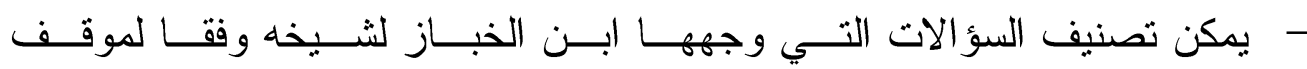

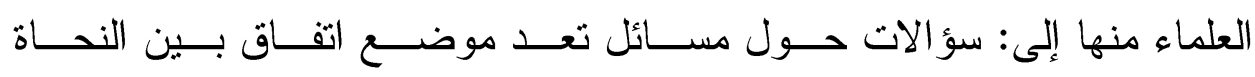
و الصرفيين، أو موضع اختلاف بينهم، أو مسائل انفردت بها السؤالات.

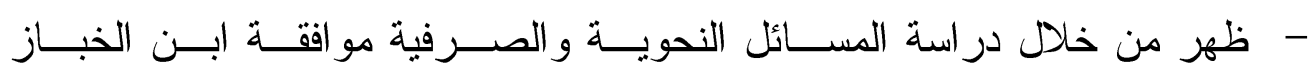

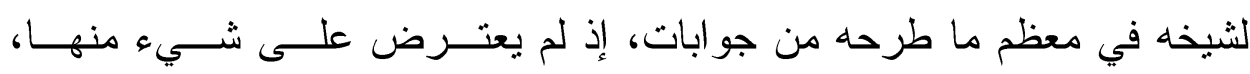

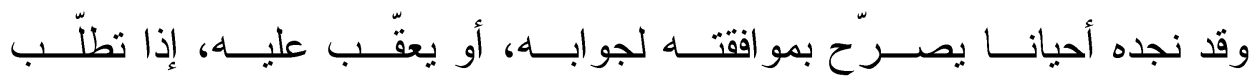
الجواب ذلك.

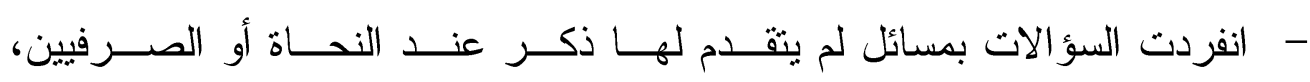

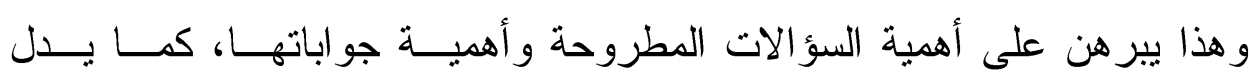

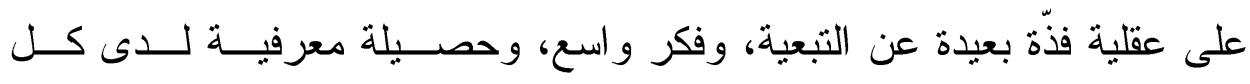

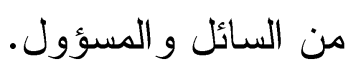

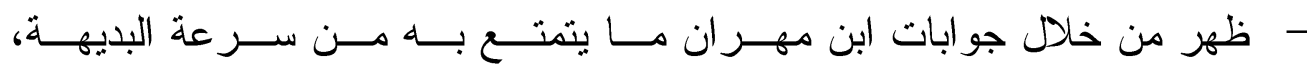
و الملكة اللغوية، و الاطلاع على كثير من العلوم.

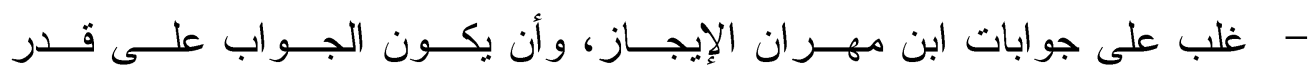

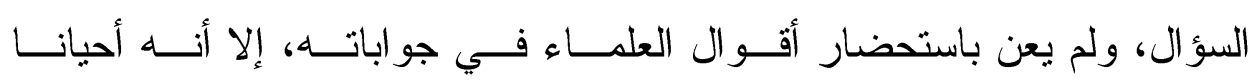
يستطرد ويذكر الثو اهد إذا تطلب الجواب ذلك. باسني هذا وأسـأل الله التوفيق و السداد، إلى طريــق الرشـــاد، وصــلـى الله وســلم وبارك على نبينا محمد و على آله وصحبه وسلم. 


\section{الهوامش}

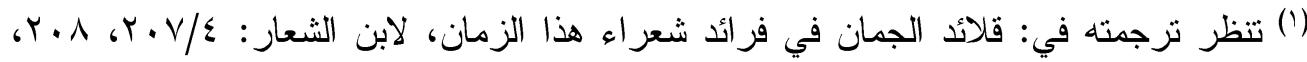

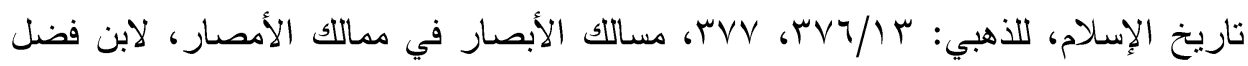

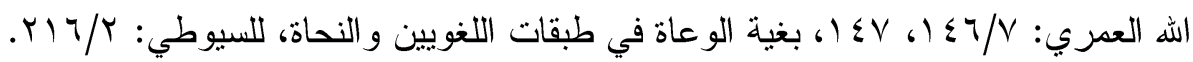

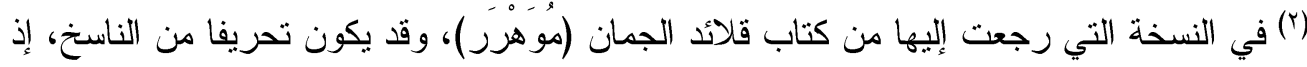

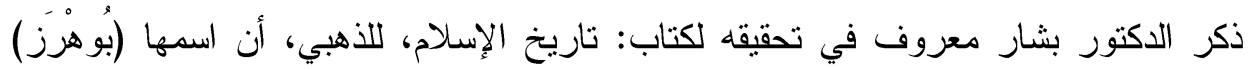

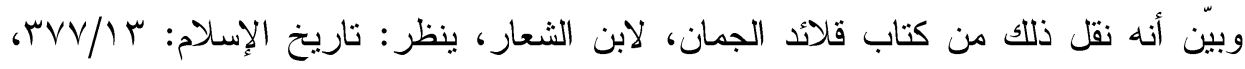

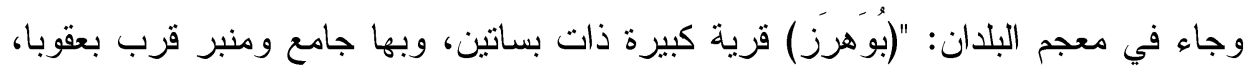

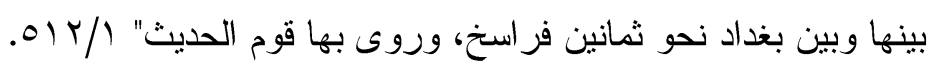

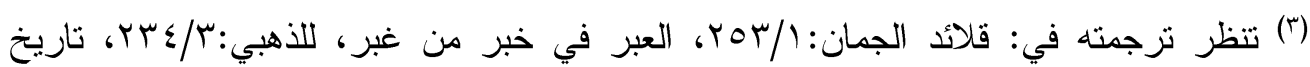

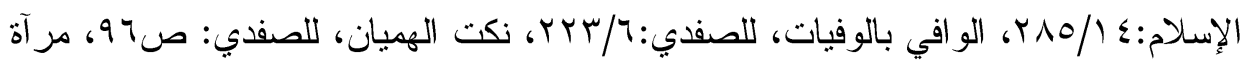

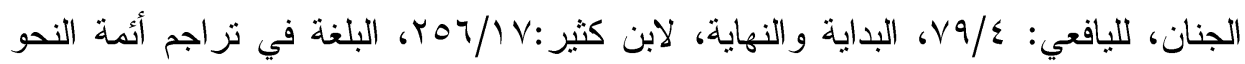

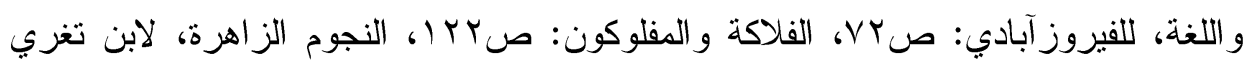

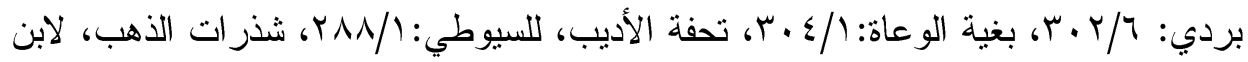

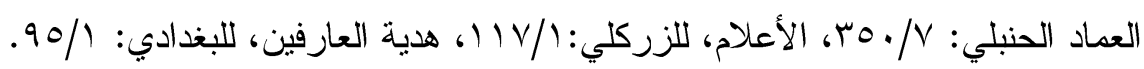

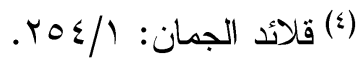

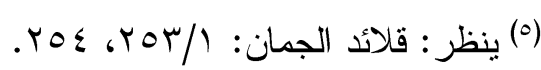

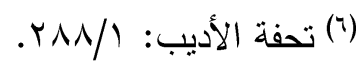

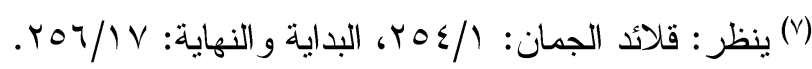

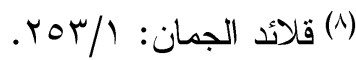

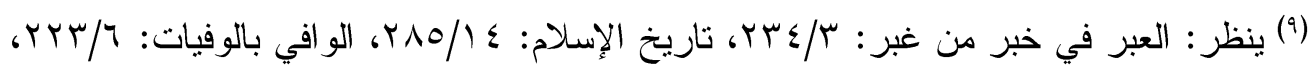

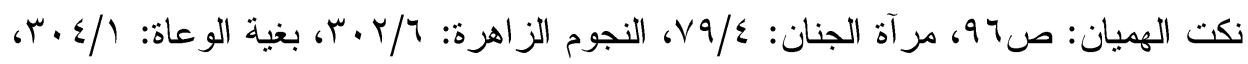

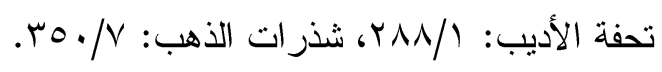

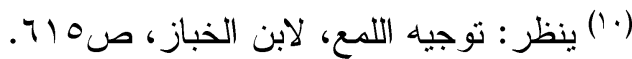

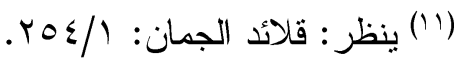

$$
\begin{aligned}
& \text { (r) ينظر : قلائد الجمان: }
\end{aligned}
$$

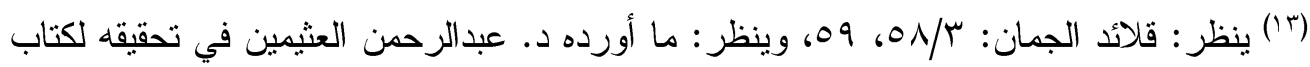

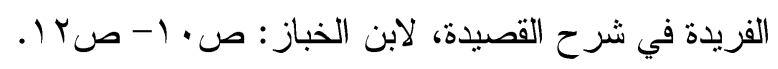




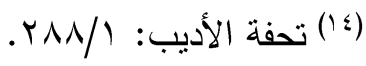

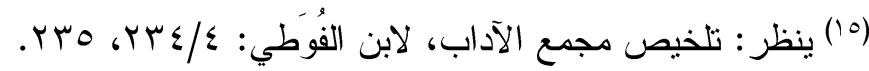

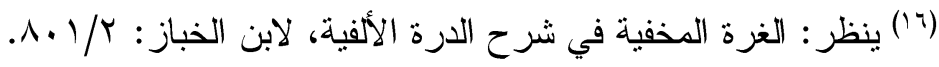

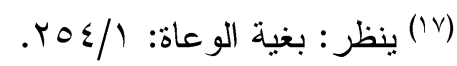

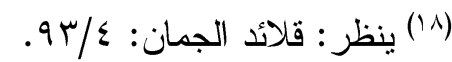

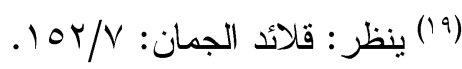

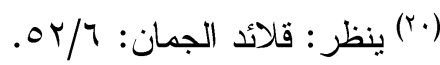

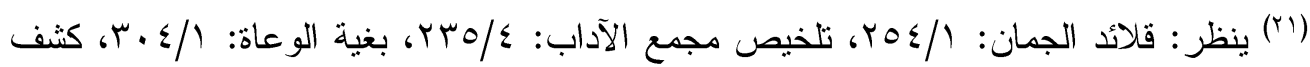

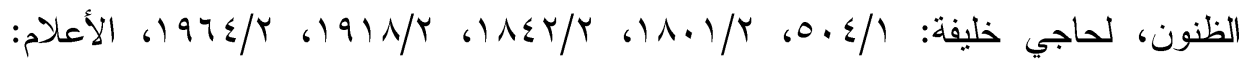

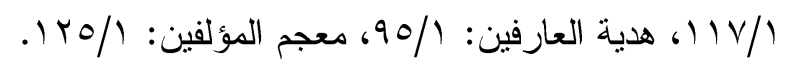

$$
\begin{aligned}
& \text { rr) ينظر : قلائد الجمان: }
\end{aligned}
$$

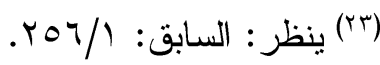

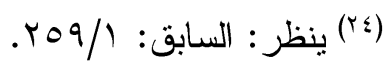

$$
\begin{aligned}
& \text { ينظر : (ro) }
\end{aligned}
$$

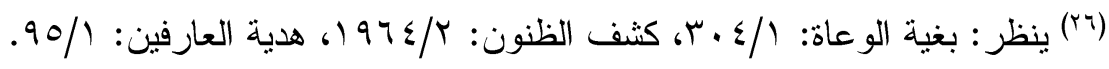

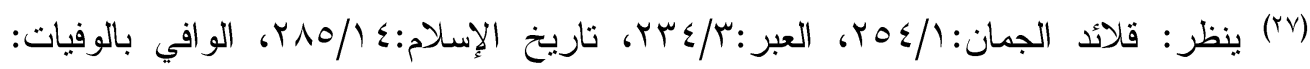

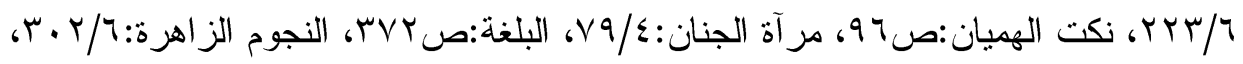

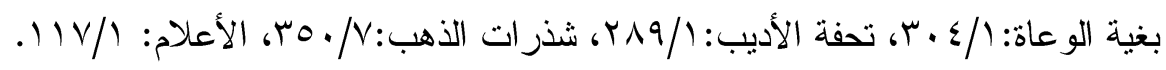

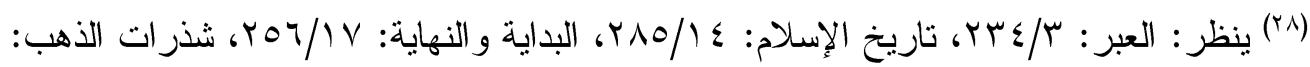

$$
\text { ro./V }
$$

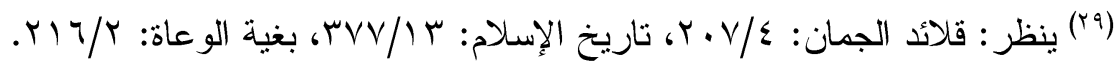

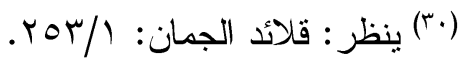

$$
\begin{aligned}
& \text { (r) تحفة الأديب: (r) }
\end{aligned}
$$

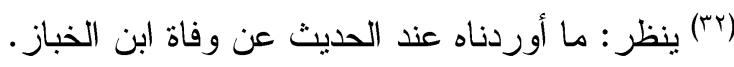

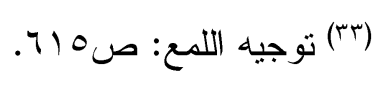

(؛־) البيتان من الطويل، ولم أهتد إلى قائلهما، وقد أوردها الجرجاني في (أسرار البلاغة). ينظر :

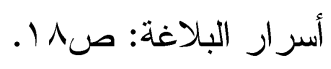




$$
\begin{aligned}
& \text { (ro) توجيه اللمع: صوV9) }
\end{aligned}
$$

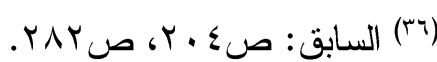

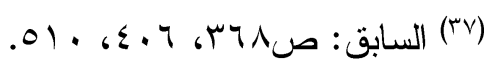

$$
\begin{aligned}
& \text { (ال) }
\end{aligned}
$$

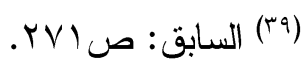

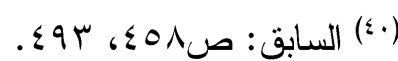

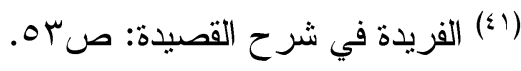

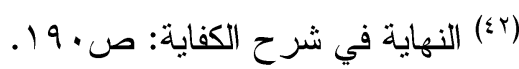

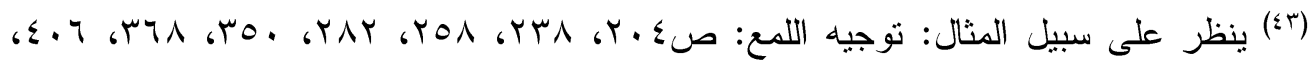

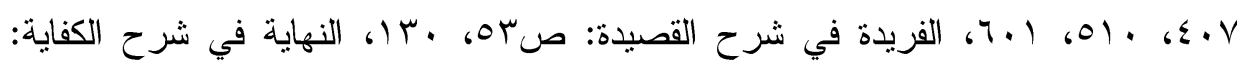

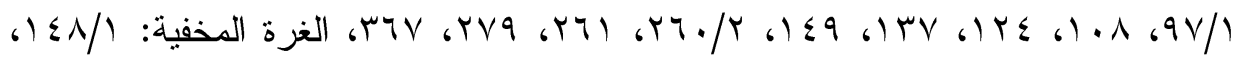

$$
, 01 V ، \leq 7 \cdot / r \text {, r } 10 \text {, r. r }
$$

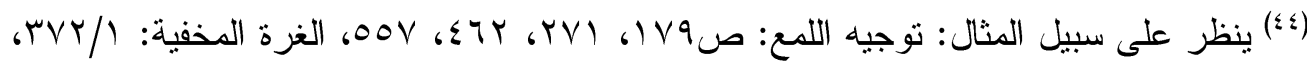

$$
.0 . \varepsilon / T
$$

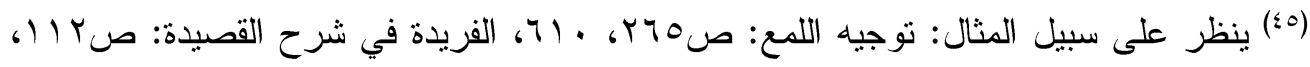

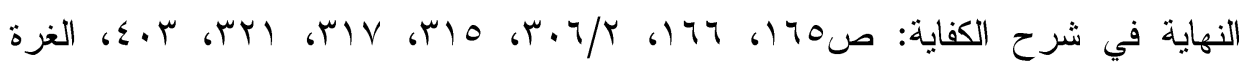

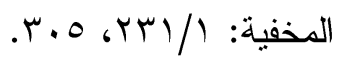

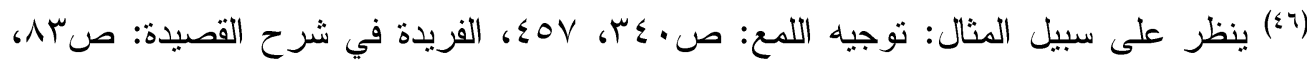

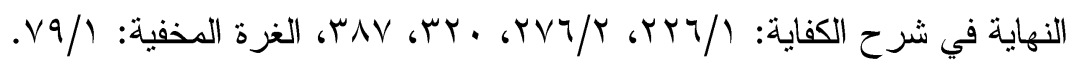

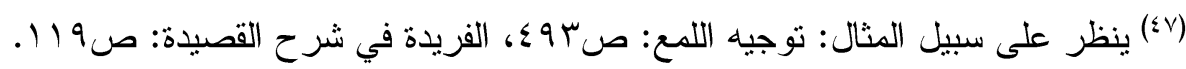

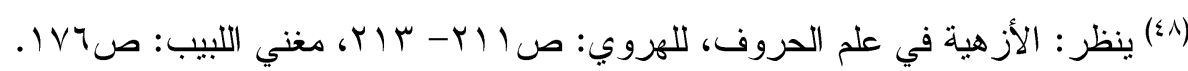

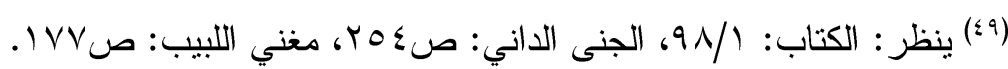

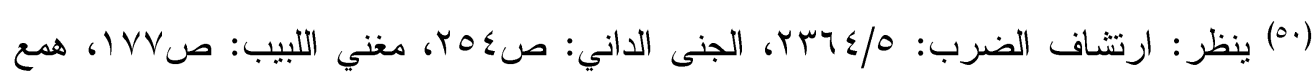

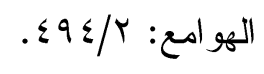

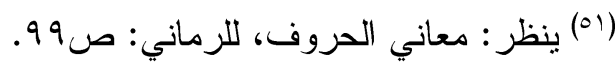

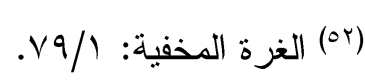




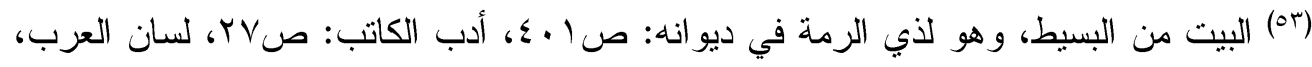

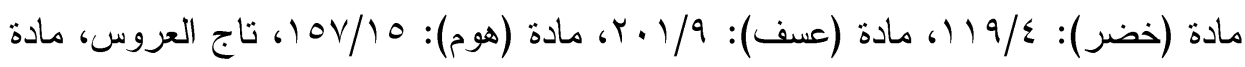

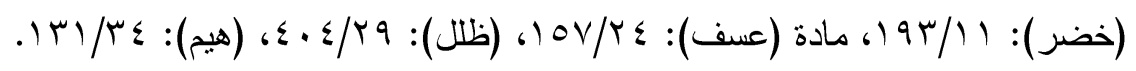

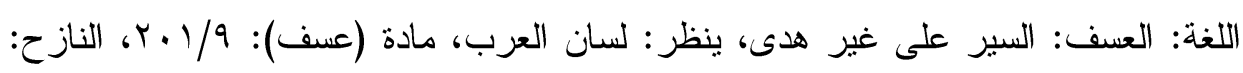

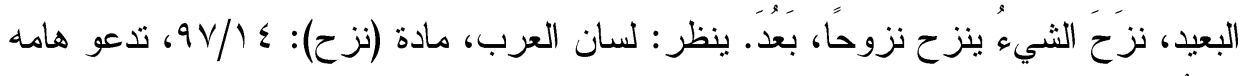

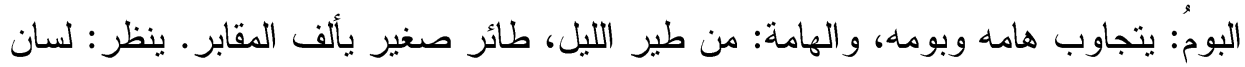

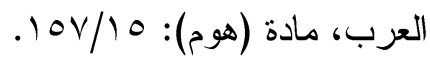

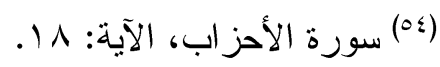

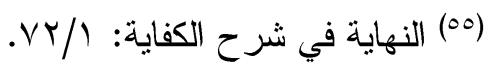

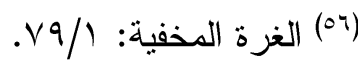

$$
\begin{aligned}
& \text { ينظر : (OV) }
\end{aligned}
$$

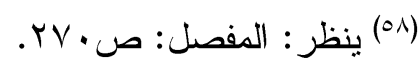

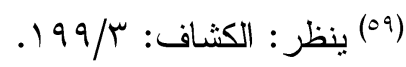

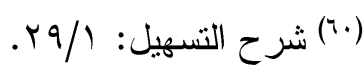

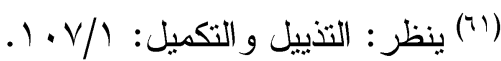

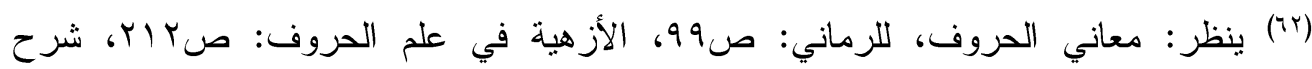

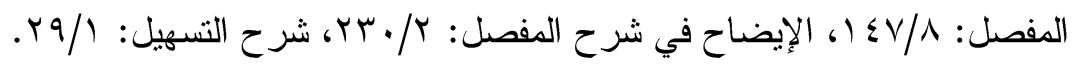

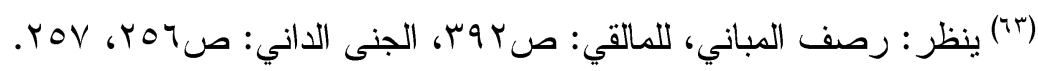

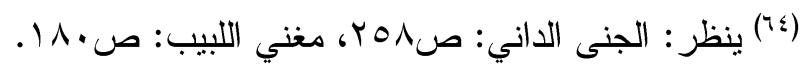

$$
\text { (7) }
$$

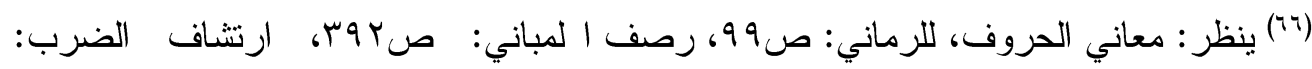

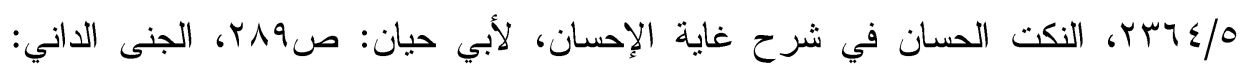

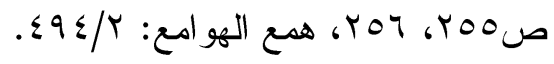

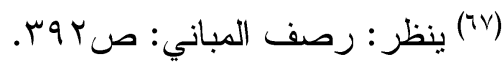

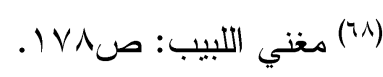

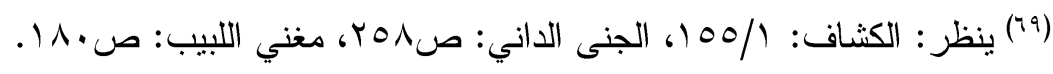

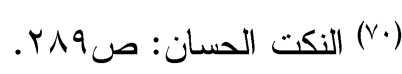




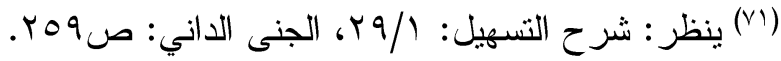

$$
\begin{aligned}
& \text { (Yr) ينظر : شرح الرضي على الكافية: (Yr) } \\
& \text { (V) } \\
& \text { (1) }
\end{aligned}
$$

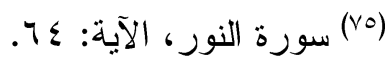

$$
\begin{aligned}
& \text { (البحر المحيط: (VT) }
\end{aligned}
$$

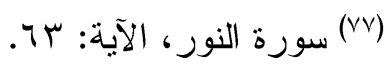

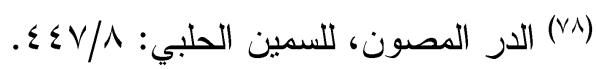

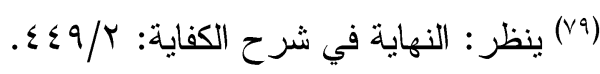

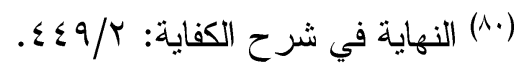

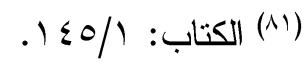

ينظر : ين المقتضب:

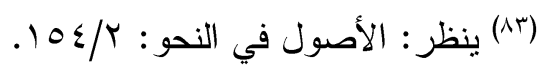

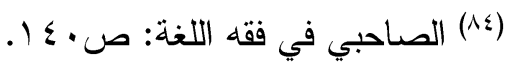

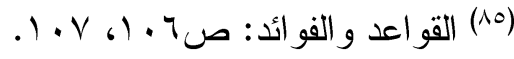

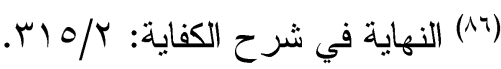

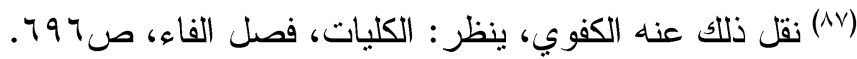

$$
\text { (A) }
$$

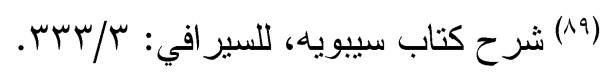

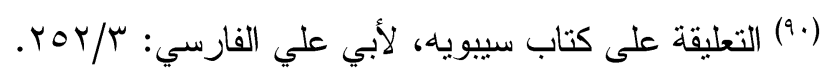

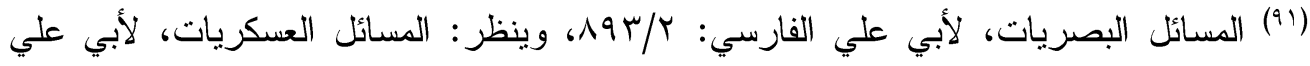

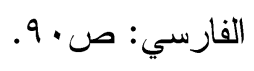

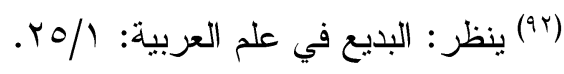

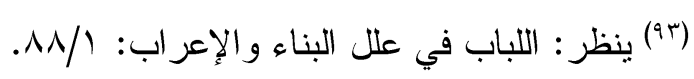

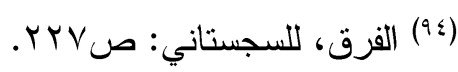

$$
\begin{aligned}
& \text { (90) الأصول في النحو: Tr/r }
\end{aligned}
$$

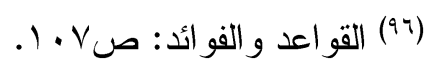




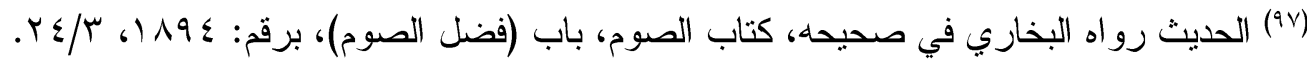

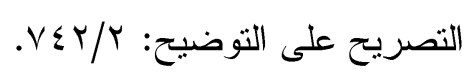

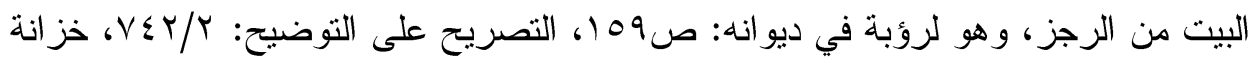

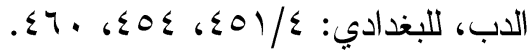

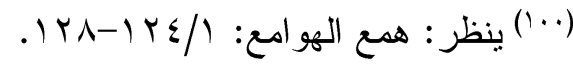

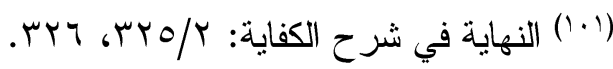

(ץ+() لم أقف في الكتاب على نص يقطع بما تقدم من مذهب سيبويه، غير أني وجدت ما يقترب من

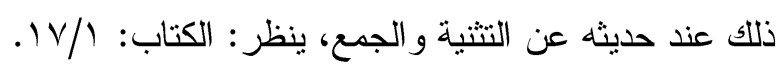

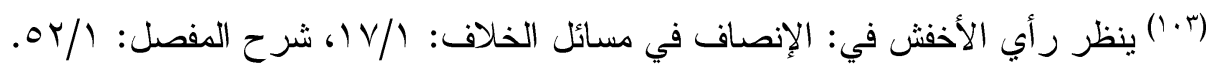

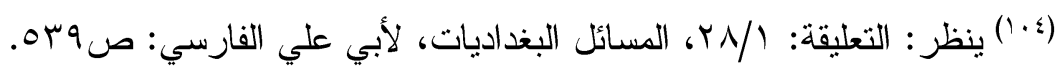

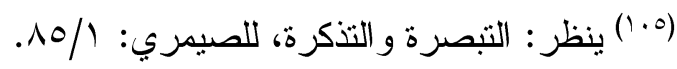

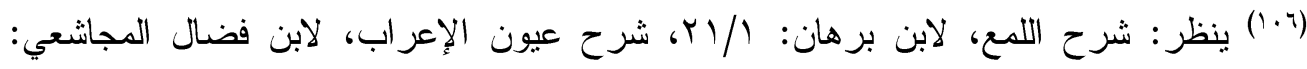

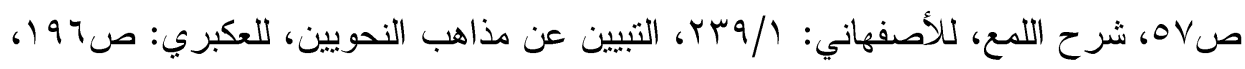

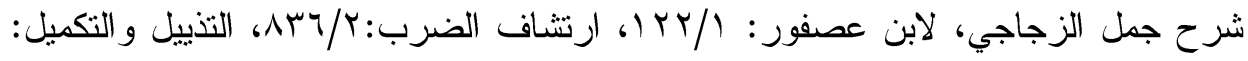

$$
\text { .11 } 11 \mathrm{~V} 0 / 1
$$

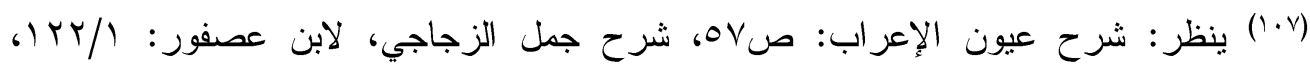

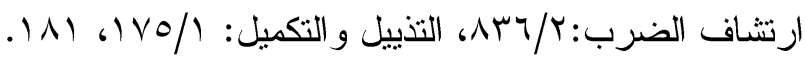

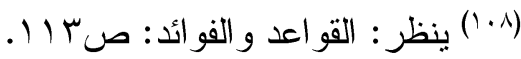

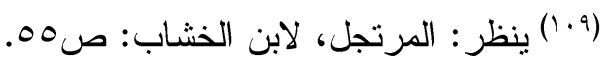

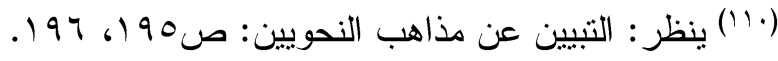

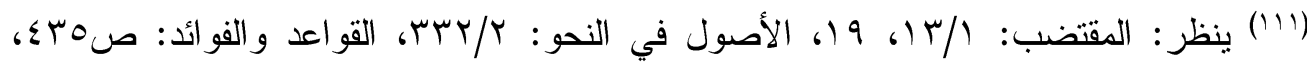
صل

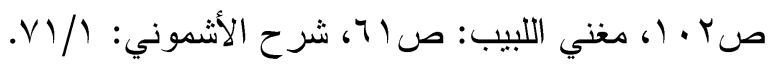

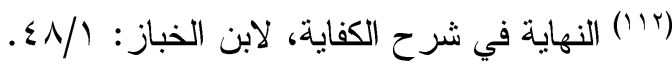

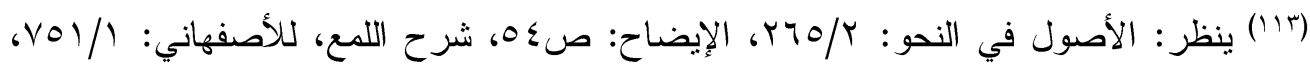

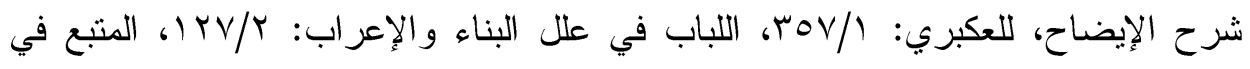

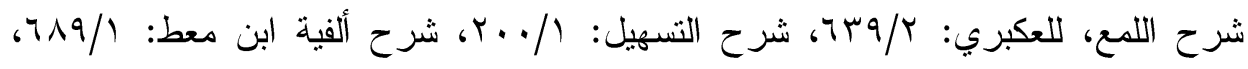




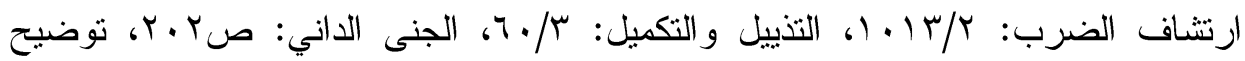

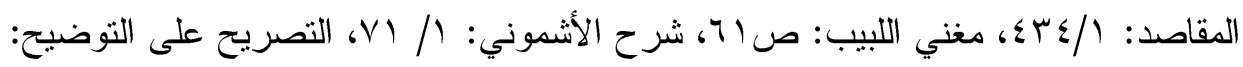

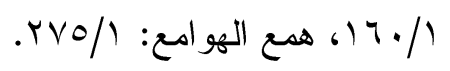

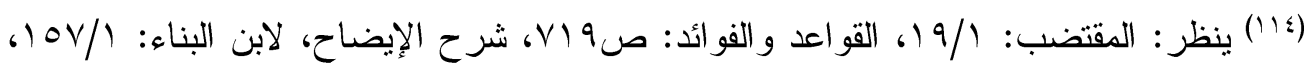

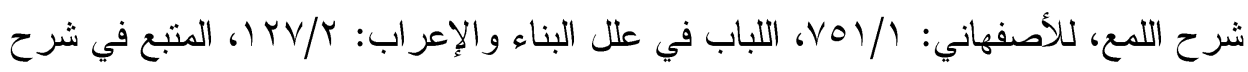

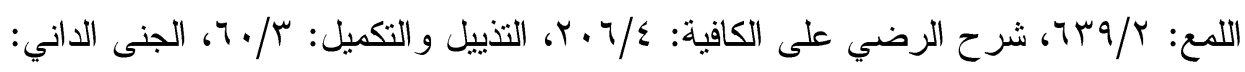

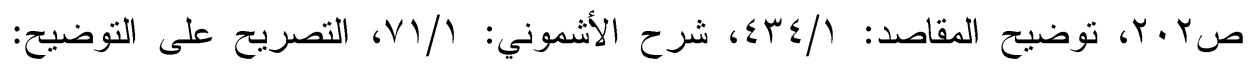

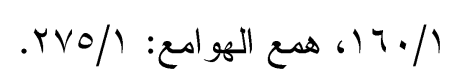

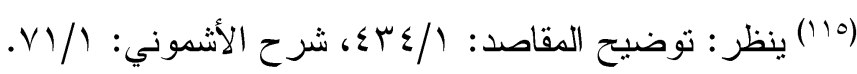

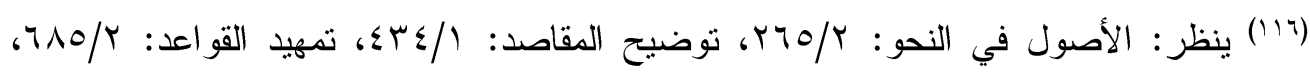

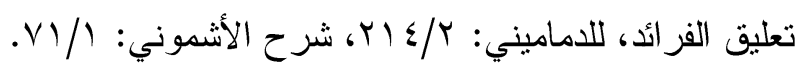

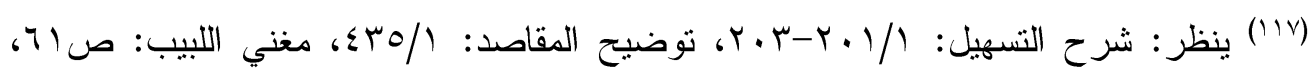

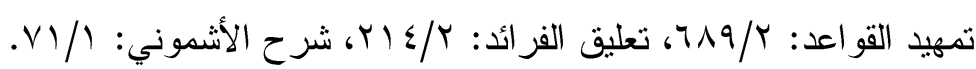

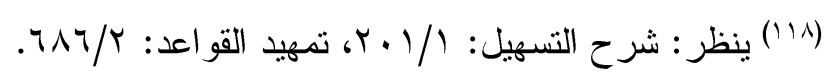

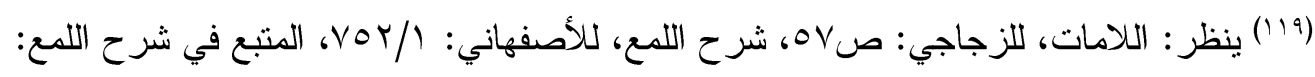

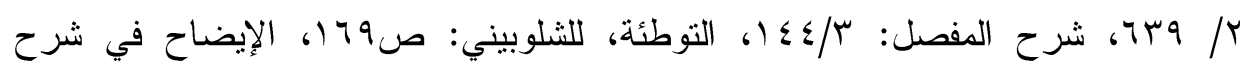

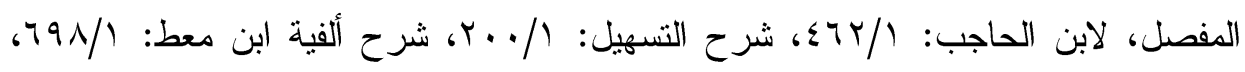

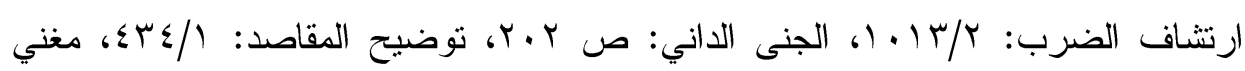

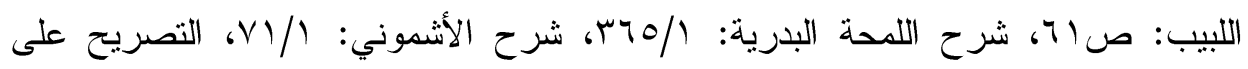

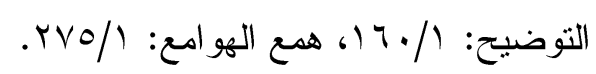

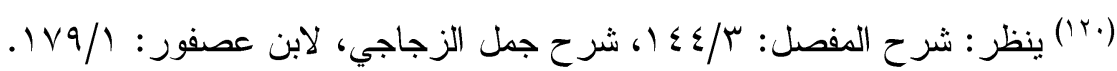

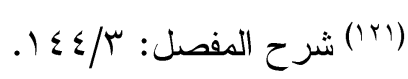

$$
\begin{aligned}
& \text { (r) شرح جمل الزجاجي، لابن عصفور: (V9/1) }
\end{aligned}
$$

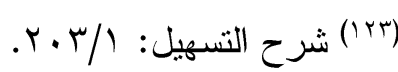

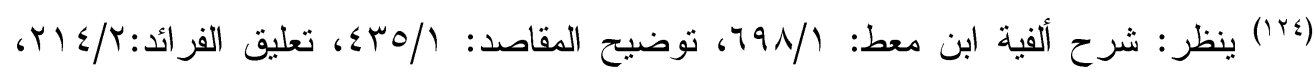

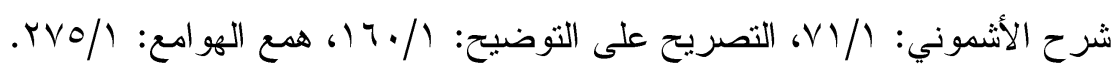




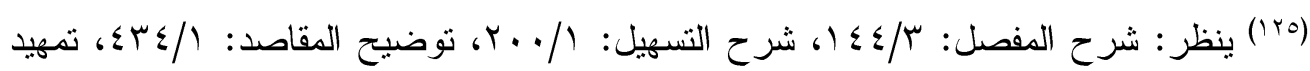

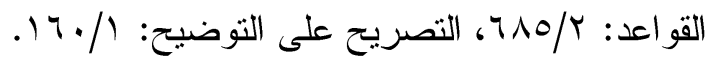

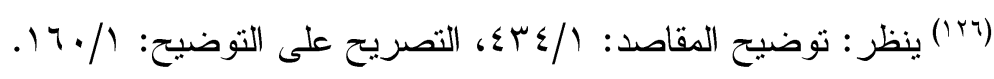

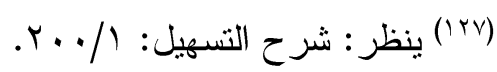

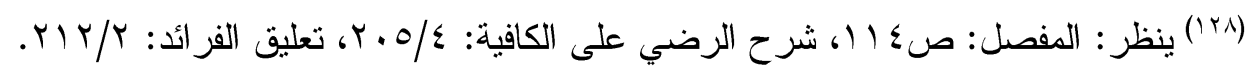

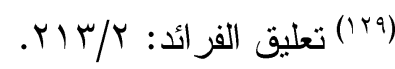

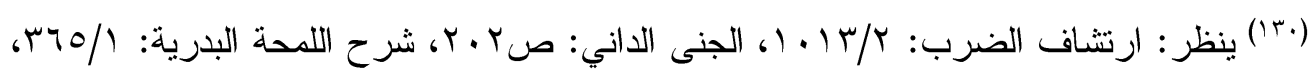

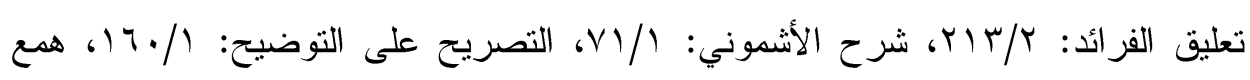

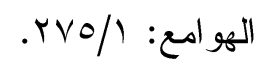

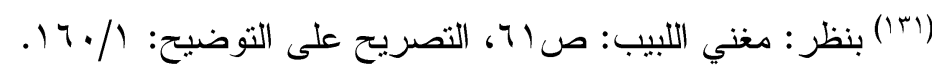

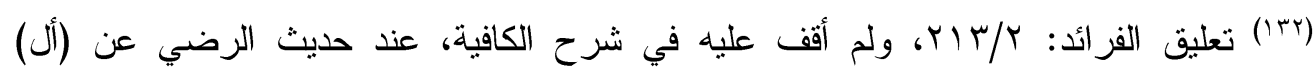

$$
\begin{aligned}
& \text { الموصولة. }
\end{aligned}
$$

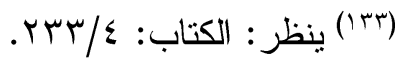

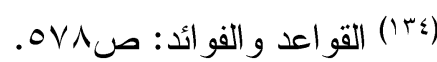

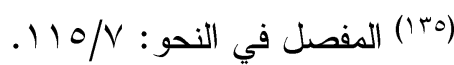

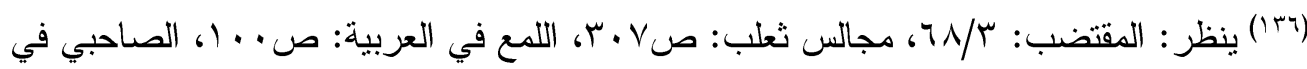

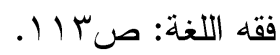

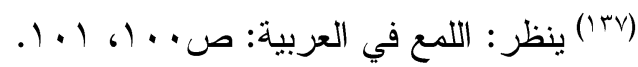

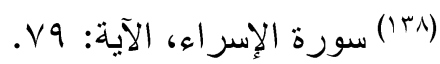

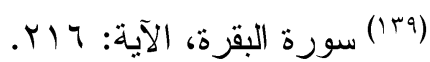

$$
\begin{aligned}
& \text { (·؛ (1) سورة القصص، الآية: } 9 .
\end{aligned}
$$

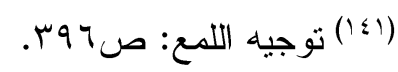

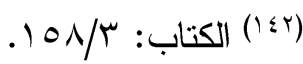

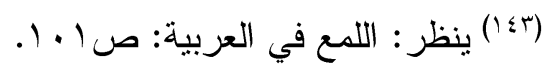

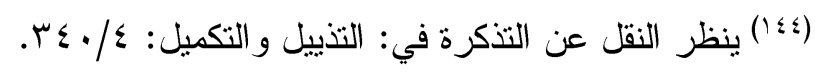

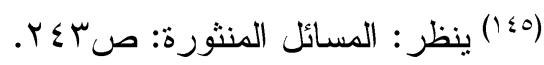

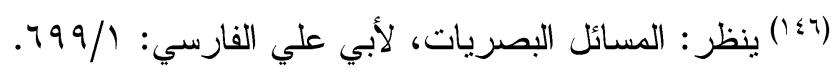




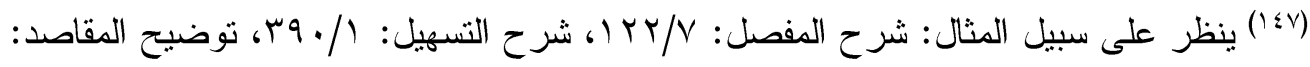

$$
.01 \mathrm{~V} / 1
$$

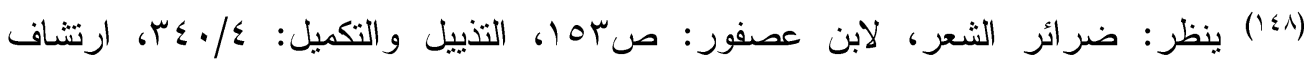

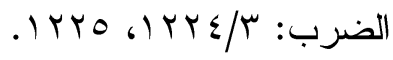

$$
\begin{aligned}
& \text { (9) (1) ينظر : الإيضاح: ص^ح. }
\end{aligned}
$$

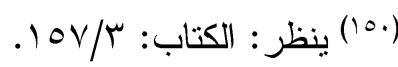

$$
\begin{aligned}
& \text { (101) ينظر : المقتضب: س/ }
\end{aligned}
$$

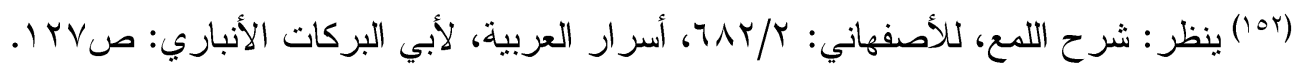

$$
\begin{aligned}
& \text { (10r) ينظر : أسرار العربية: صل بr I ا. } \\
& \text { (10) شرح الرضي على الكافية: 70/7 ـ 1. 10 1. }
\end{aligned}
$$

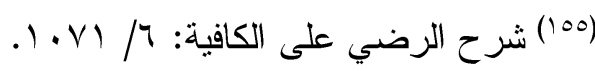

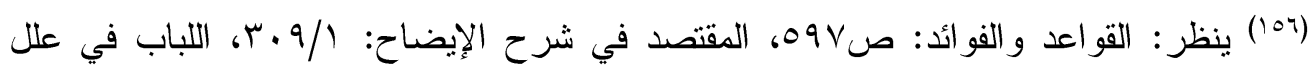

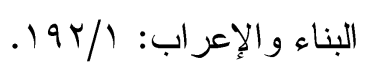

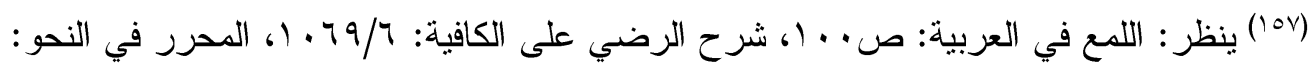

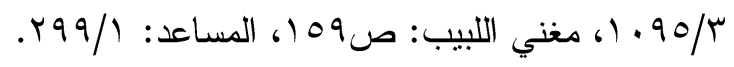

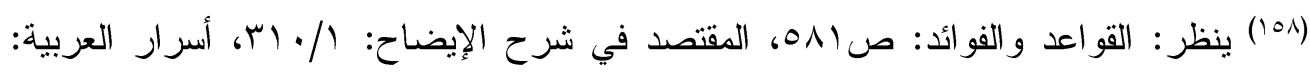

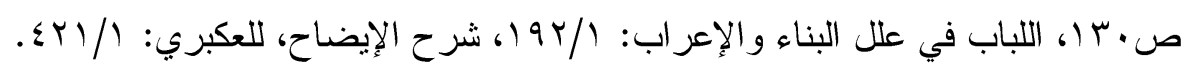

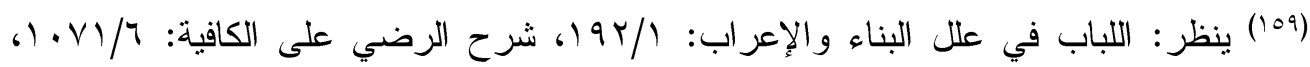

$$
\begin{aligned}
& \text { مغني اللبيب: صو09 الـ }
\end{aligned}
$$

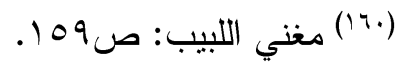

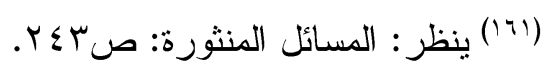

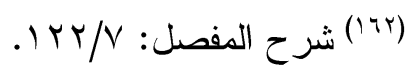

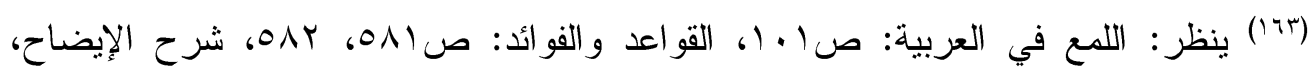

$$
\text { للعكبري: إن / }
$$

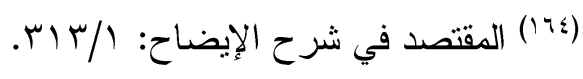$$
\text { (170) ينظر : توجيه اللمع: صع كا ا. }
$$ 


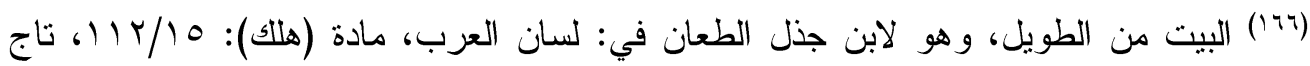

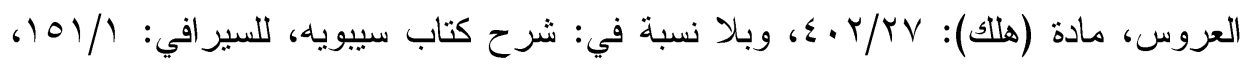

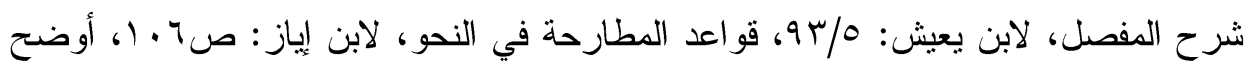

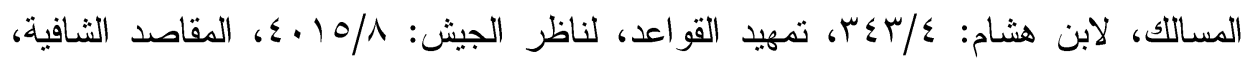

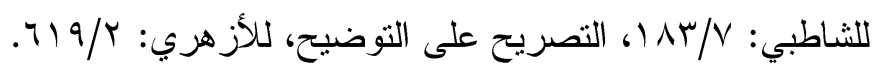

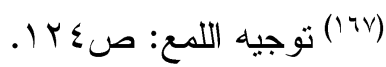

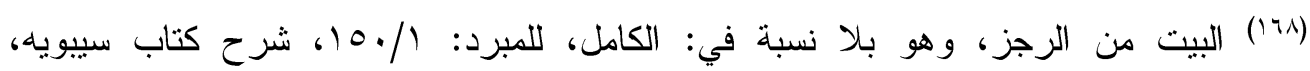

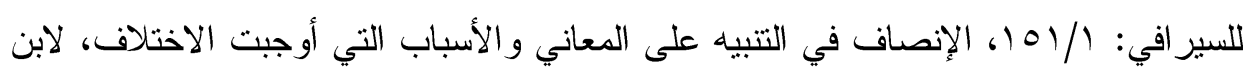

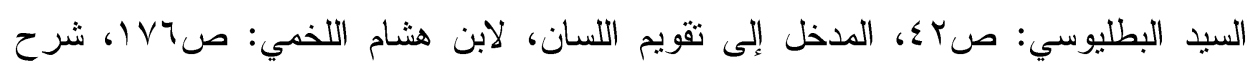

$$
\begin{aligned}
& \text { المفصل: 9r/0. }
\end{aligned}
$$

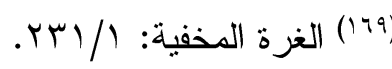

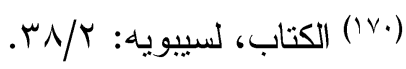

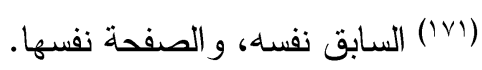

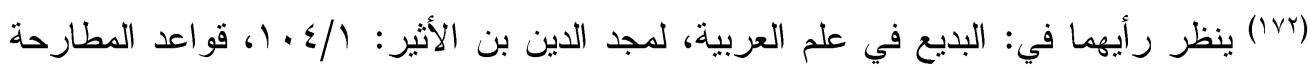

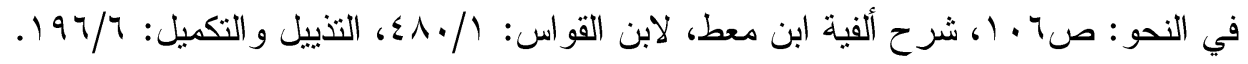

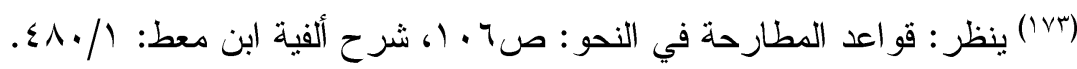
(1V乞)

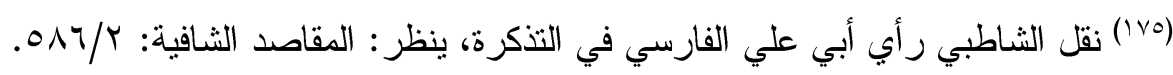

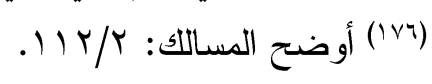

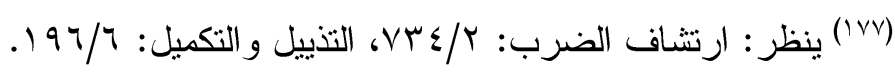

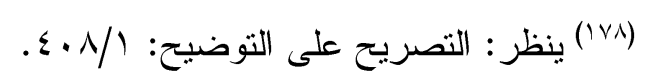

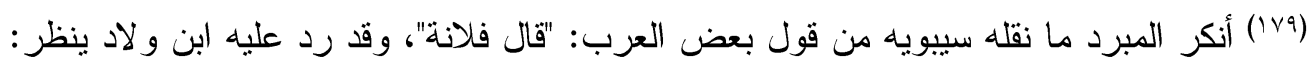

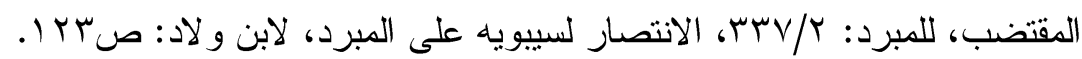

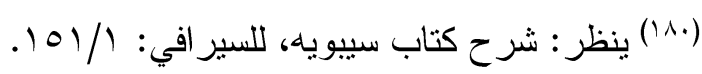

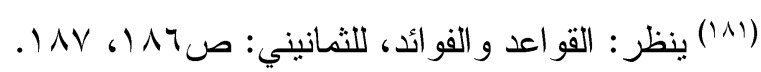

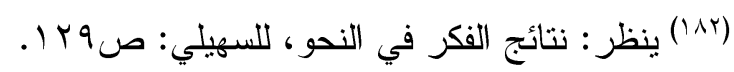

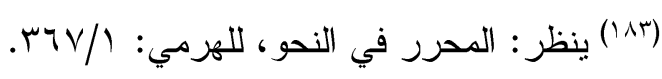




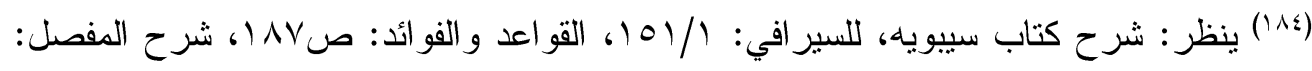

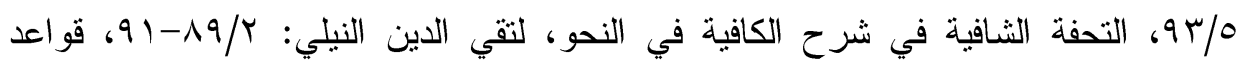

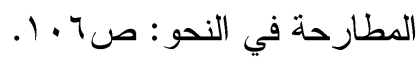

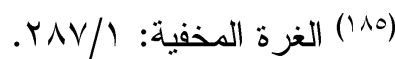

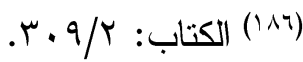

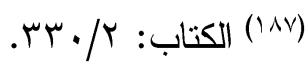

(1)

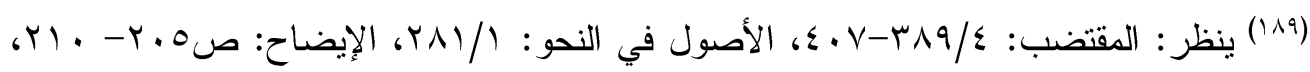

المفصل: ص07-1 7.

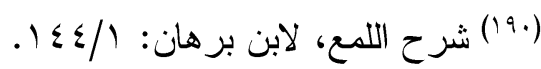

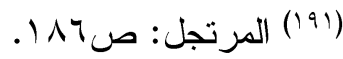

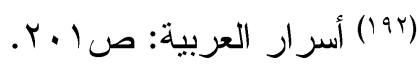

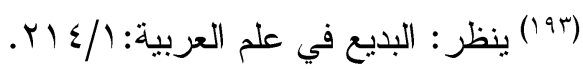

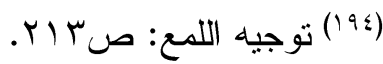

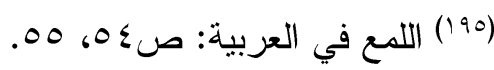

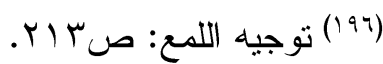

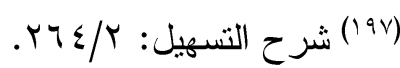

(191)

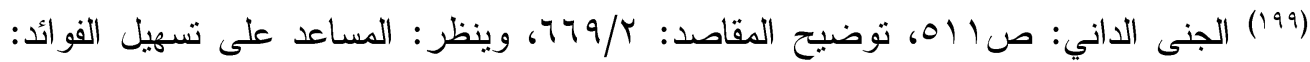

$$
\begin{aligned}
& .0 \leqslant 1 / 1
\end{aligned}
$$

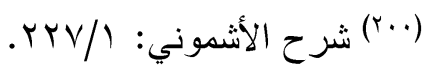

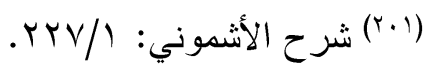

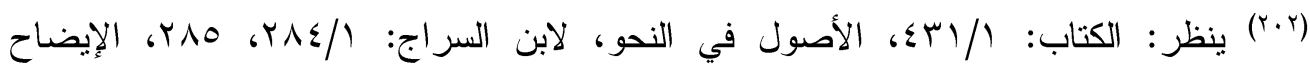

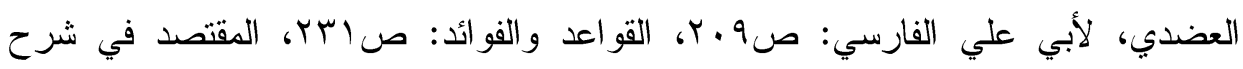

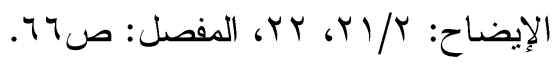

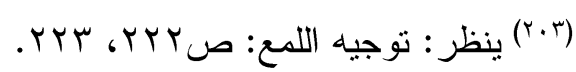

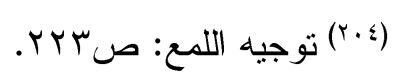




$$
\begin{aligned}
& \text { (r.0) }
\end{aligned}
$$

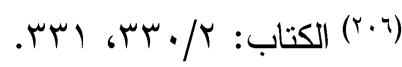

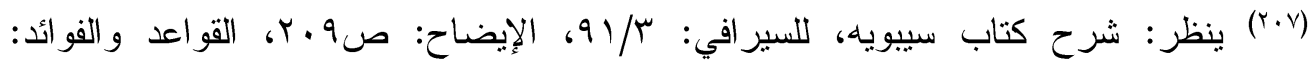

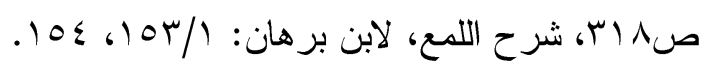

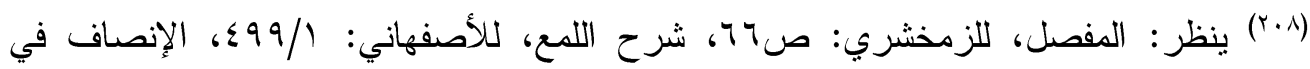

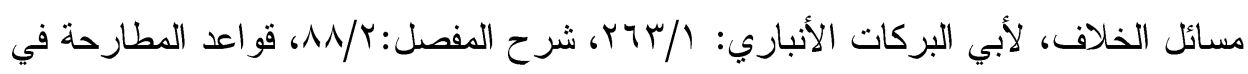

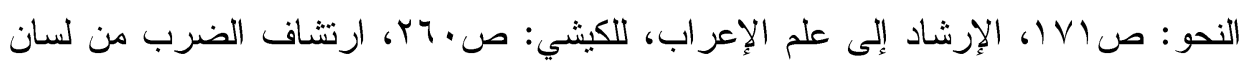

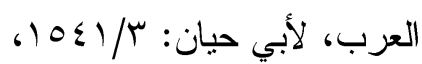

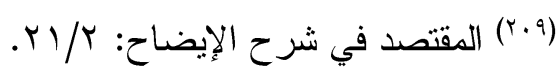

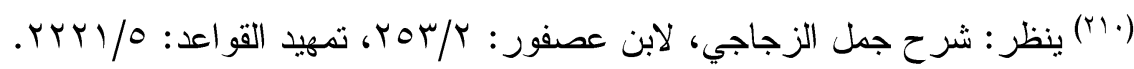

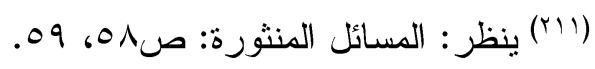

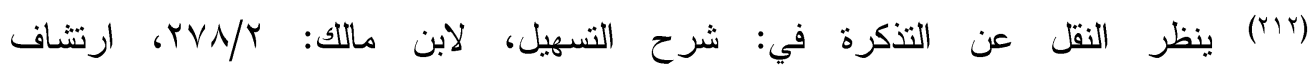

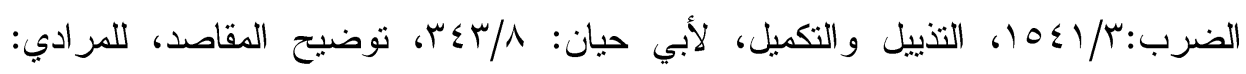
1TV/

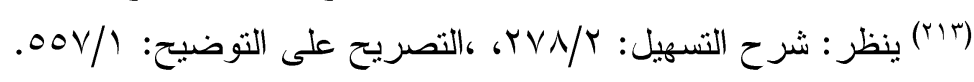

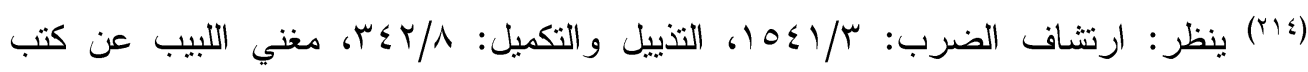

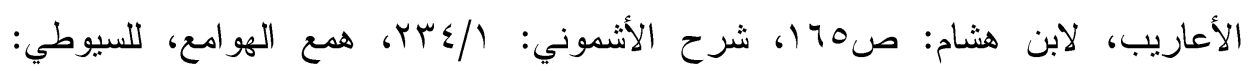

$$
r \cdot T / r
$$

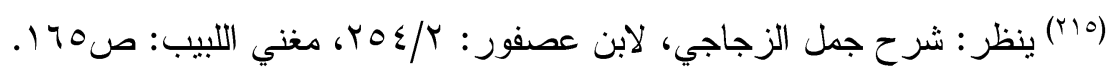

$$
\text { (r) }
$$

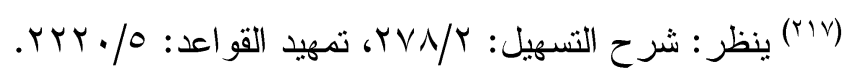

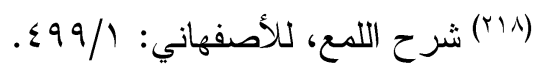

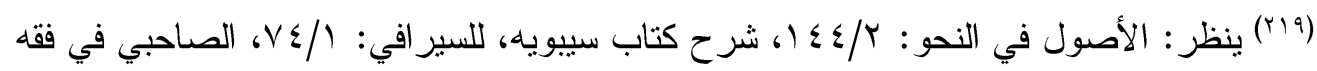

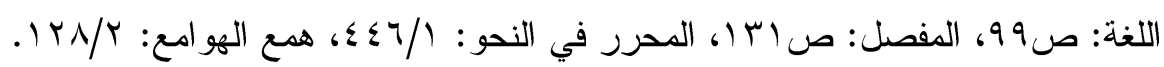

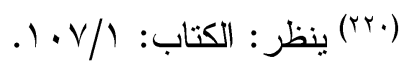

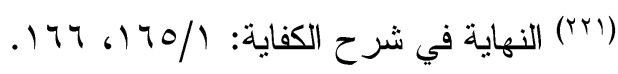

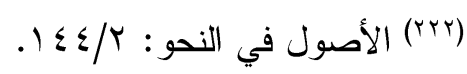




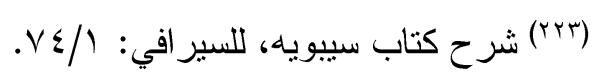

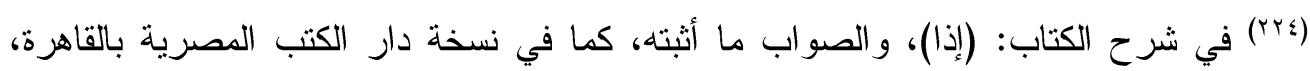

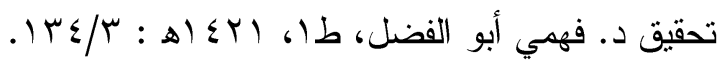

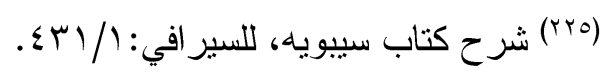

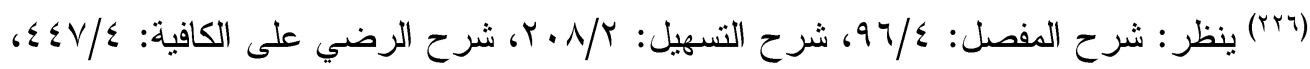

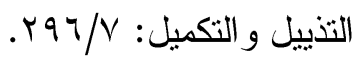

$$
\begin{aligned}
& \text { الجنى الداني:صYV (TYV) }
\end{aligned}
$$

ينظر : (YrA)

$$
\begin{aligned}
& .1 Y N / T \\
& \text { (Yrq) }
\end{aligned}
$$

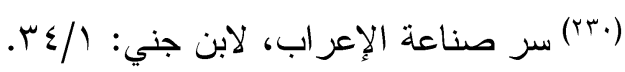

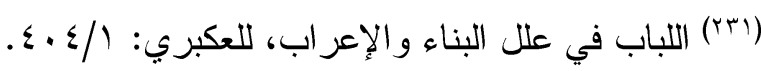

$$
\begin{aligned}
& \text { (rrr) }
\end{aligned}
$$

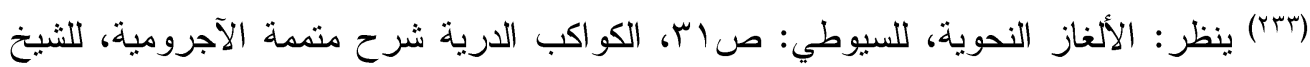

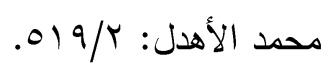

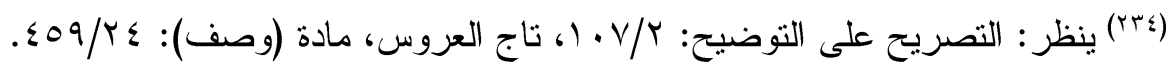

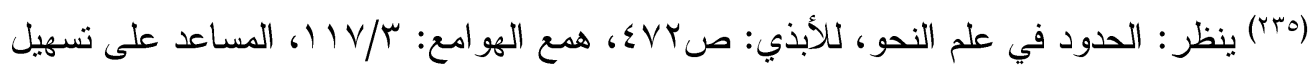

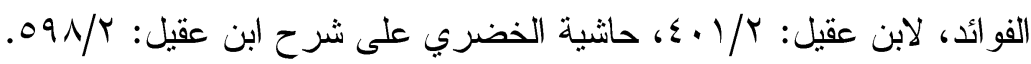

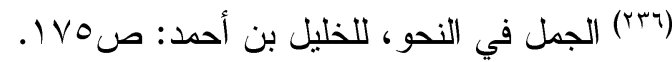

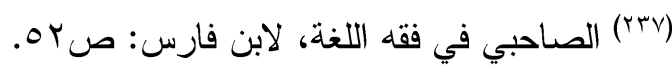

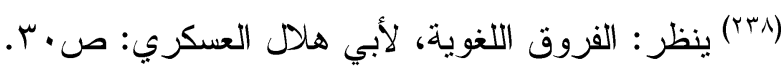

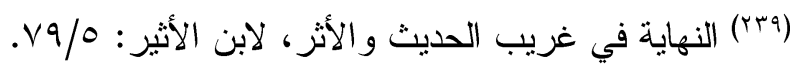

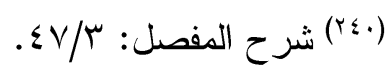

(1)

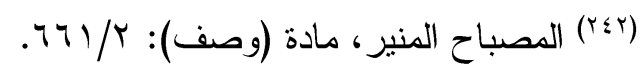

(T)

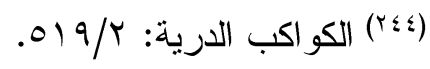




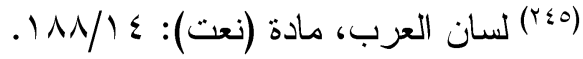

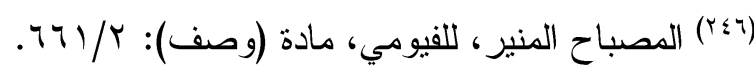

ينظر : الكتاب: / (r)

$$
\begin{aligned}
& \text {. } r V-r T / r
\end{aligned}
$$

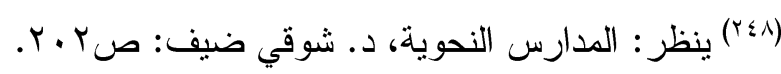

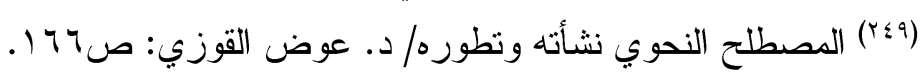

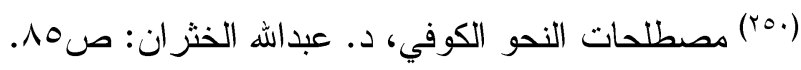

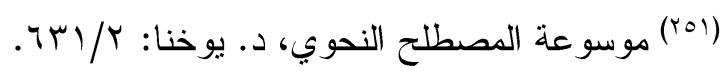

$$
\begin{aligned}
& \text { ) } \\
& \text { (ror) }
\end{aligned}
$$

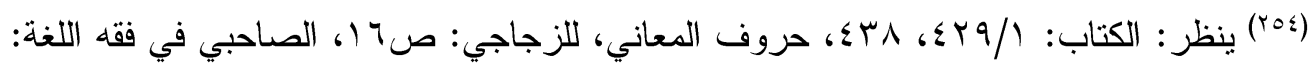

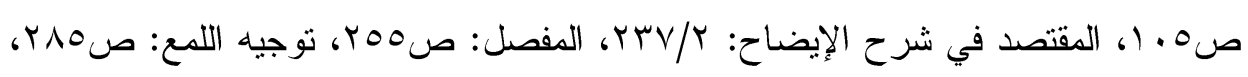

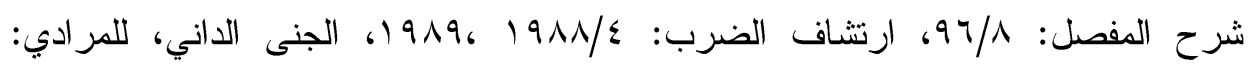

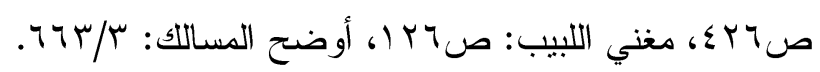

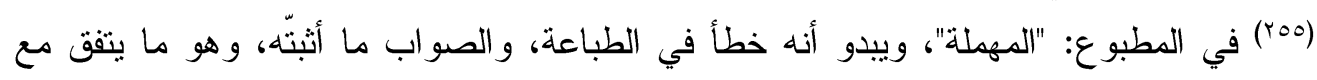

$$
\text { السياق. }
$$

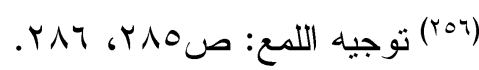

ينظر: أحكام القرآن، للجصاص: rov)

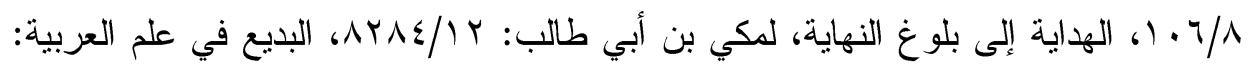

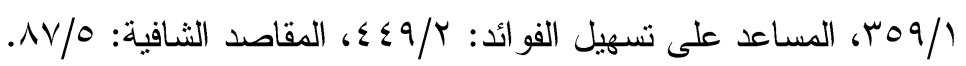

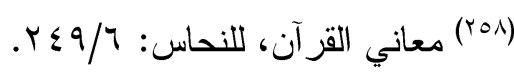

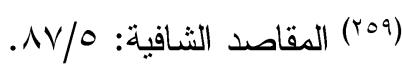

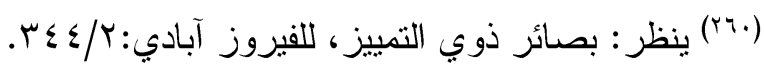

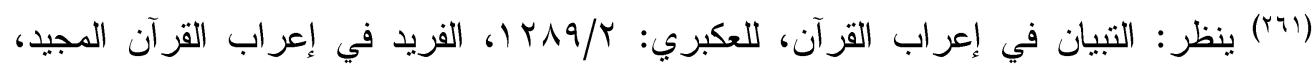

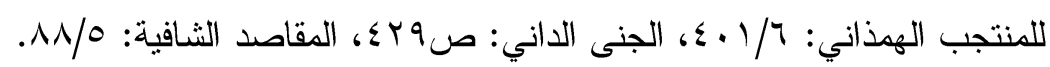

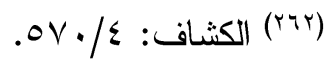

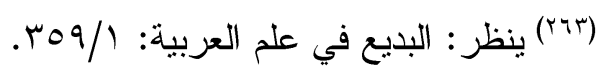




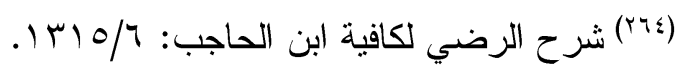

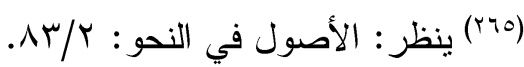

$$
\begin{aligned}
& \text { (זיז) الكتاب: }
\end{aligned}
$$

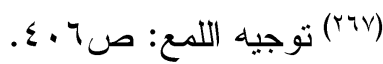

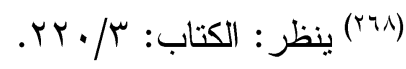

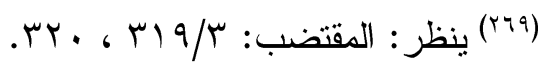

$$
\begin{aligned}
& \text { (Yv.) } \\
& \text { (YY) } \\
& \text { (YY) }
\end{aligned}
$$

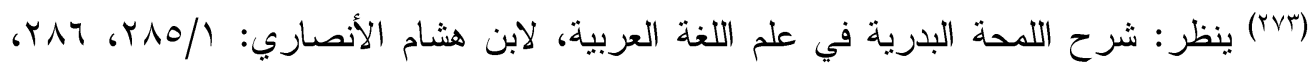

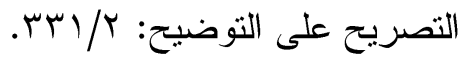

$$
\begin{aligned}
& \text { (YV) }
\end{aligned}
$$

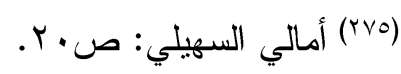

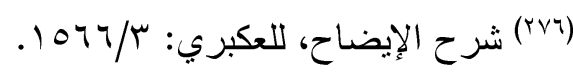

$$
\begin{aligned}
& \text { شرح اللمحة البدرية: YYV) } \\
& \text { (YV) }
\end{aligned}
$$

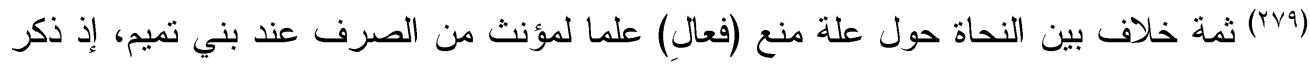

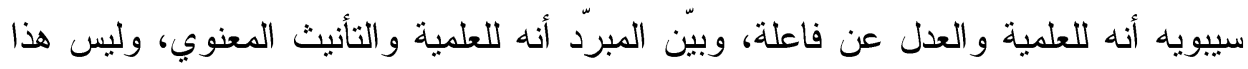

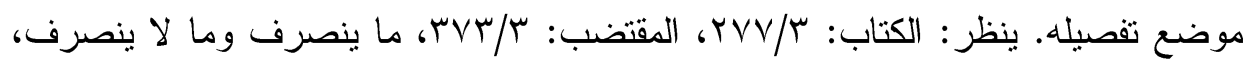

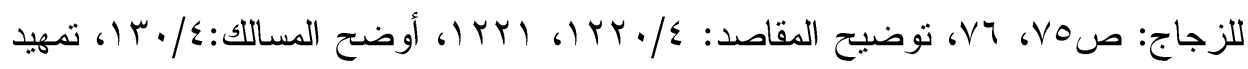

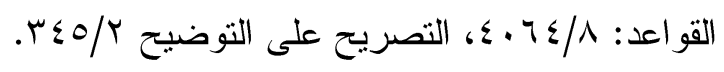

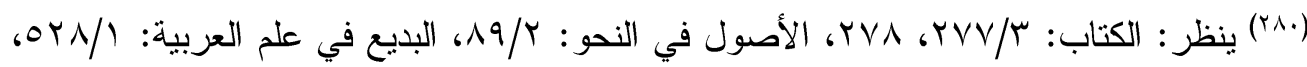

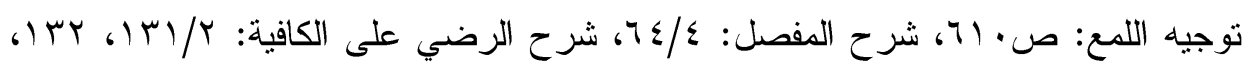

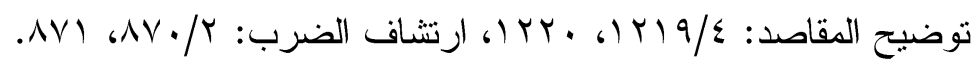

(Y)

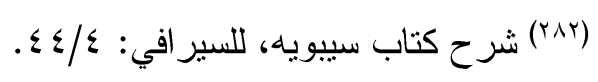

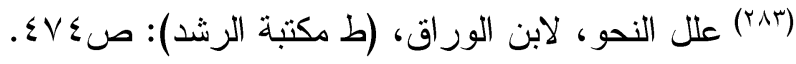




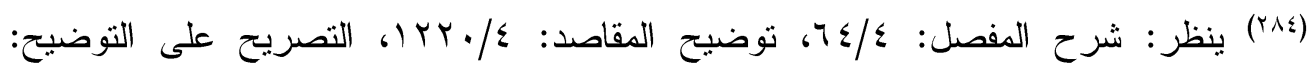
. $\mathrm{r} \leq \mathrm{T} / \mathrm{r}$

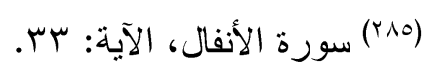

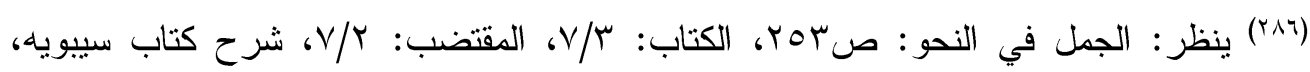

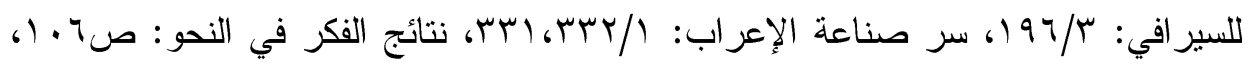

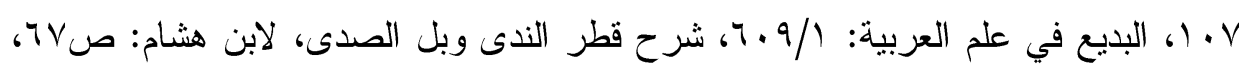

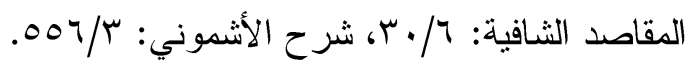

$$
\begin{aligned}
& \text { (rAv) }
\end{aligned}
$$

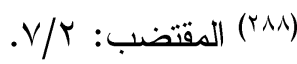

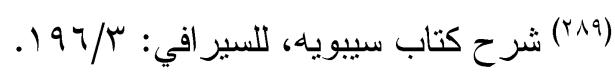

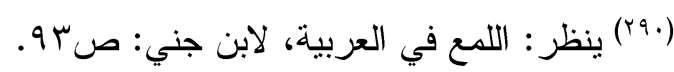

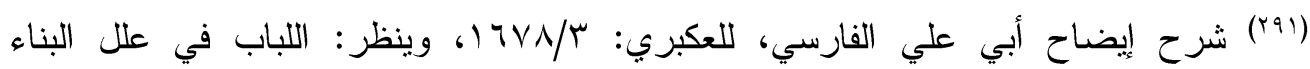

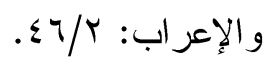

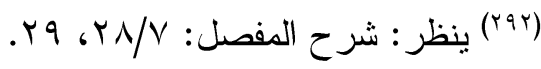

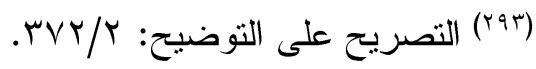

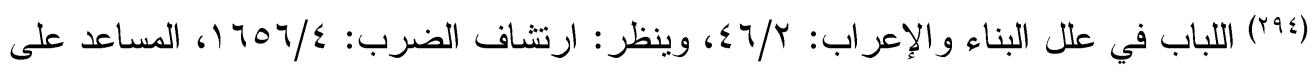

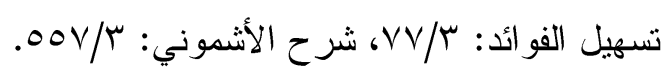

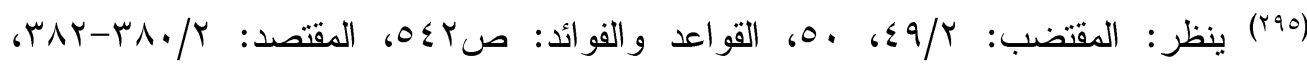

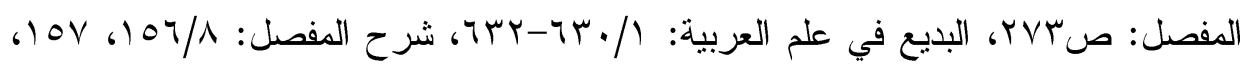

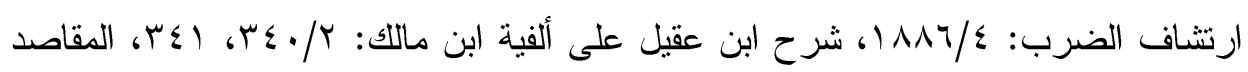

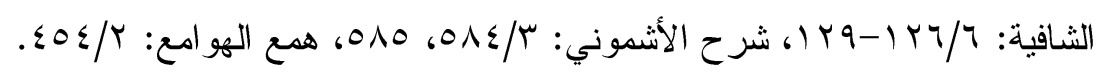

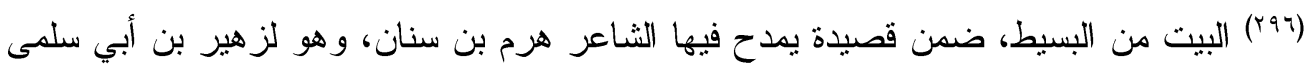

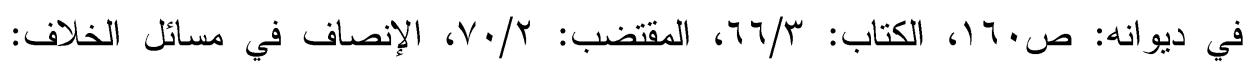

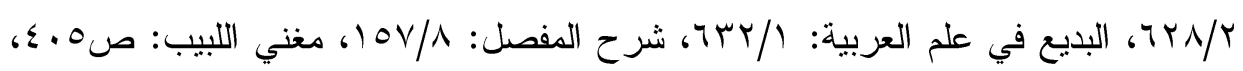

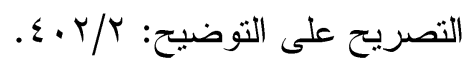

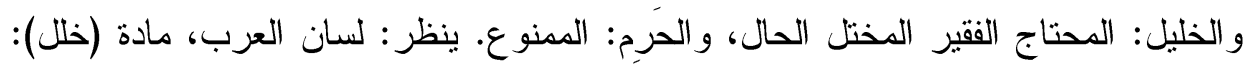

$$
\text { ( }
$$




$$
\text { (r9V) }
$$

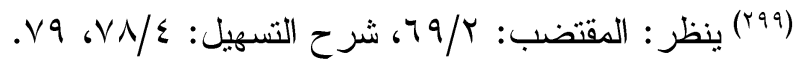

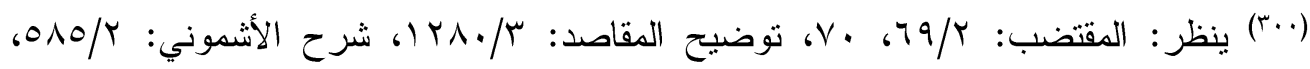
.017

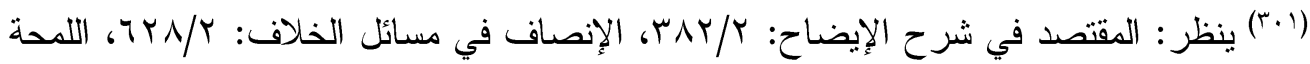

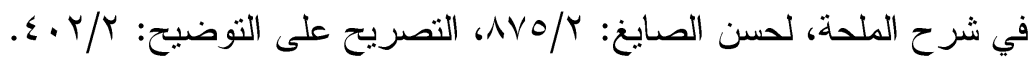

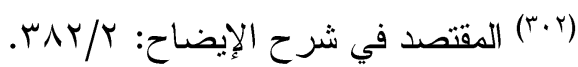

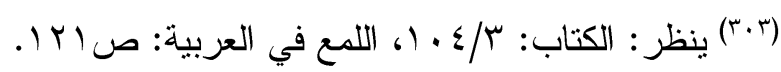

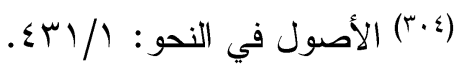

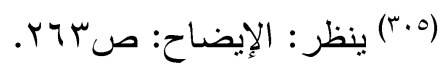

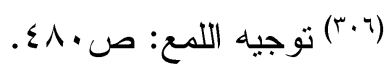

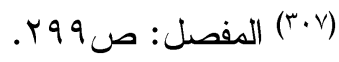

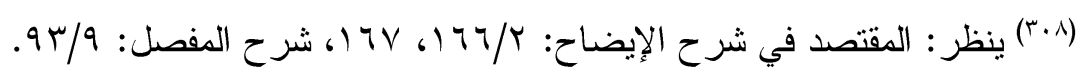

$$
\text { (r.9) }
$$

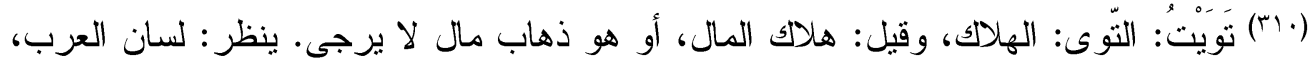

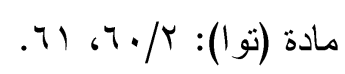

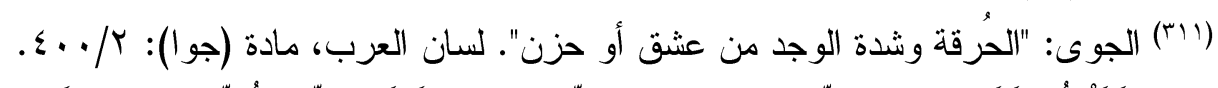

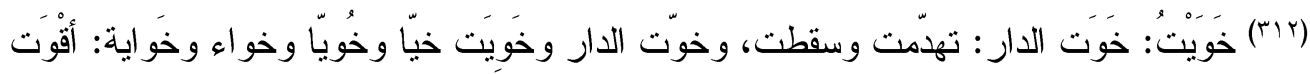

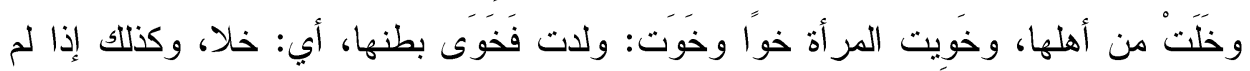

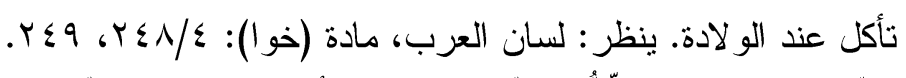

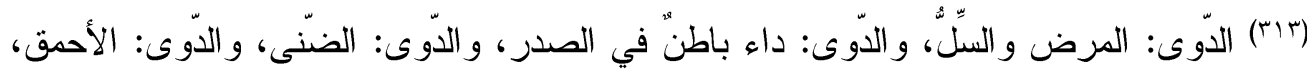

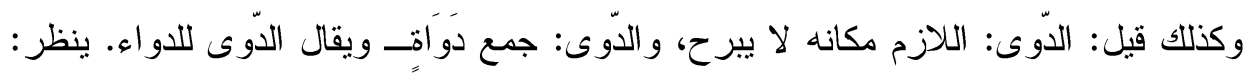

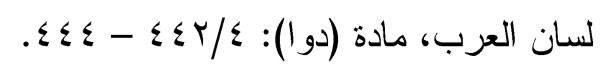

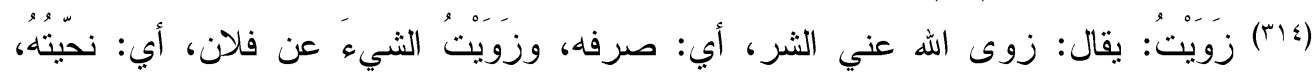

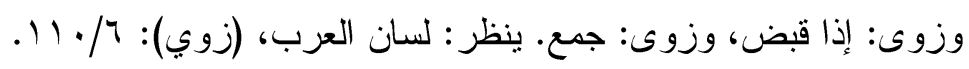




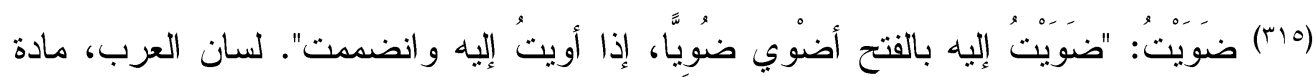

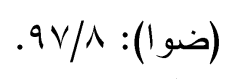

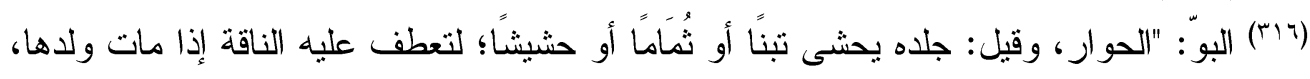

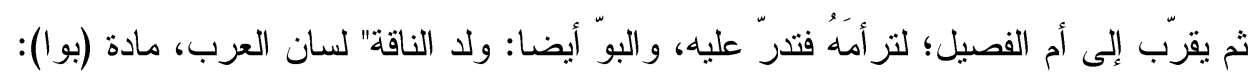

$$
\text { ort/1 }
$$

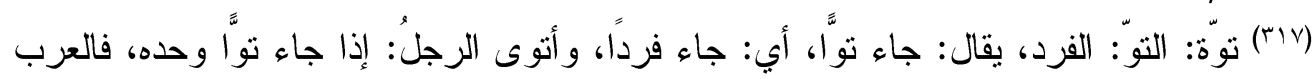

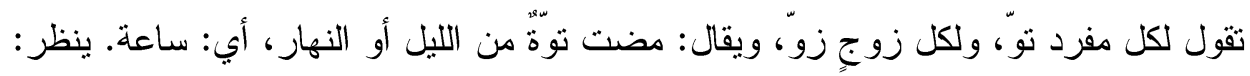

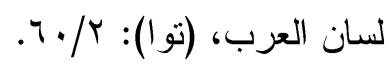

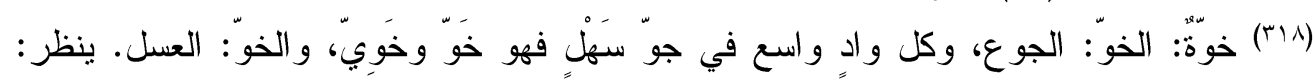

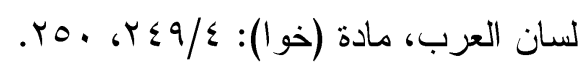

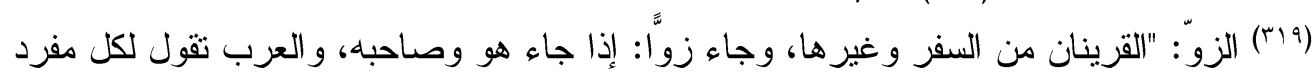

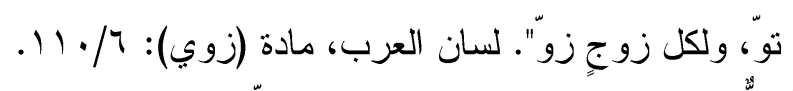

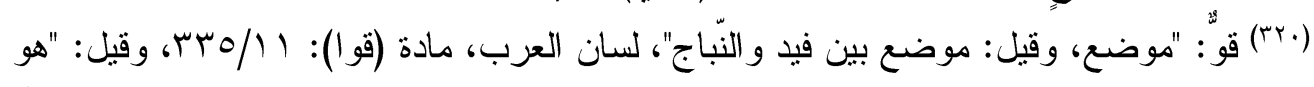

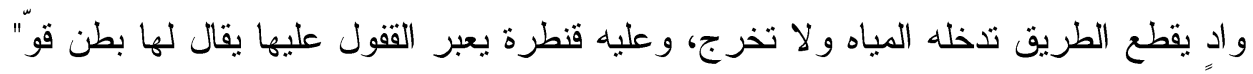

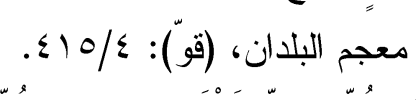

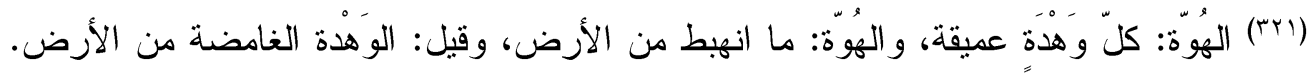

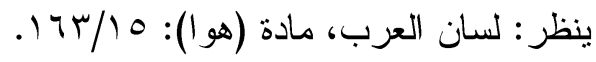

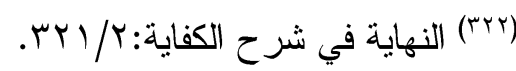

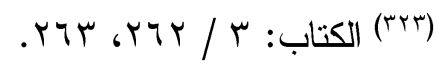

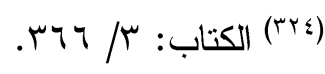

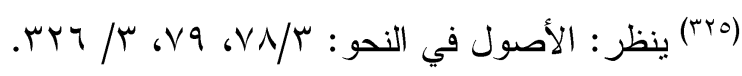

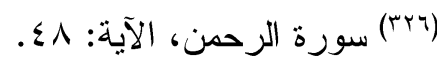

$$
\begin{aligned}
& \text { (rrV) }
\end{aligned}
$$

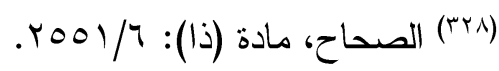

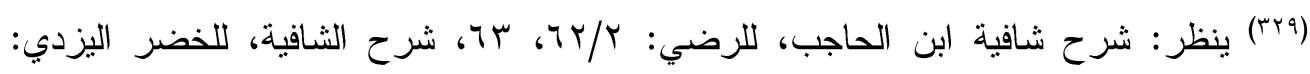

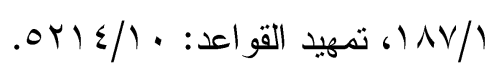

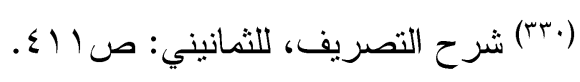




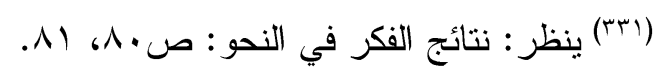

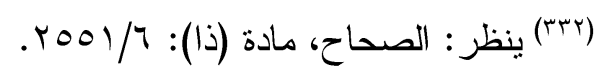

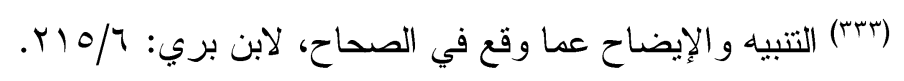

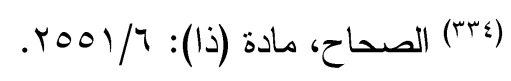

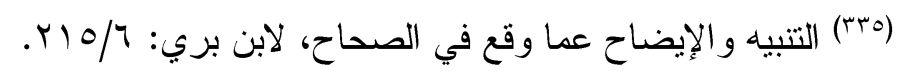

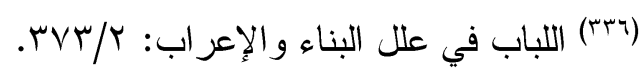

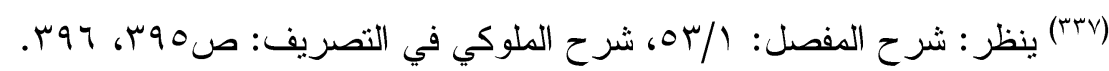

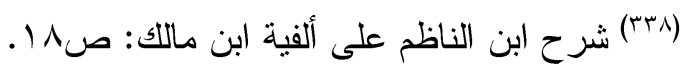

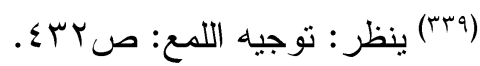

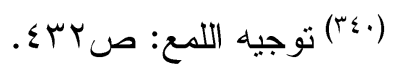

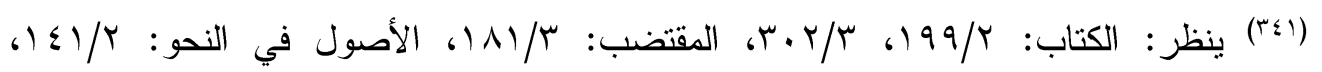

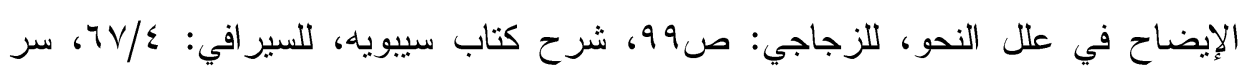

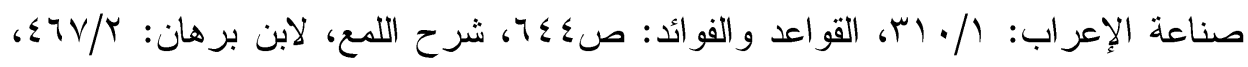

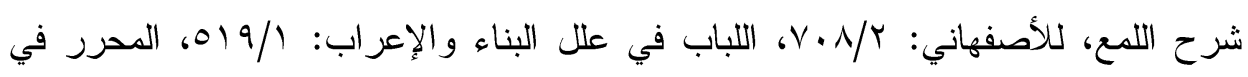

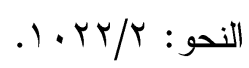

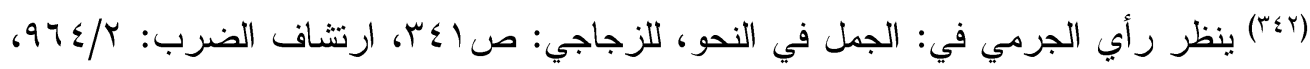

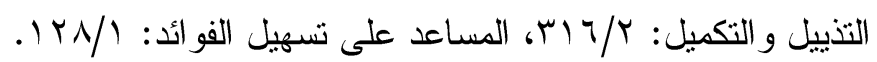

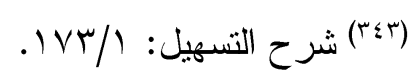

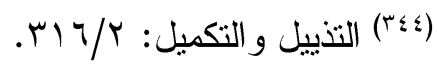

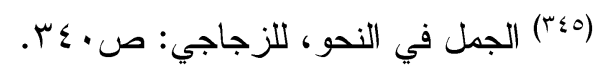

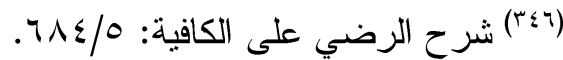

$$
\begin{aligned}
& \text { ) }
\end{aligned}
$$

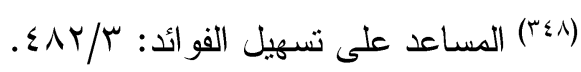

$$
\text { . }
$$

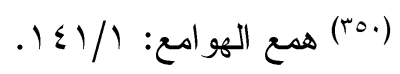

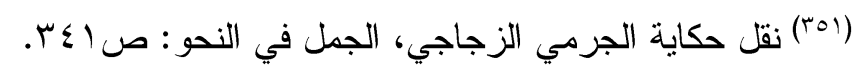

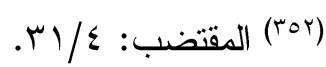




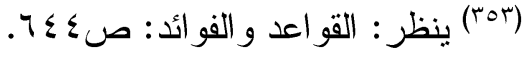

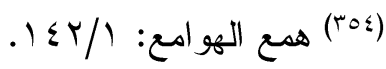

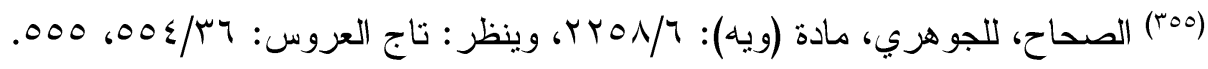

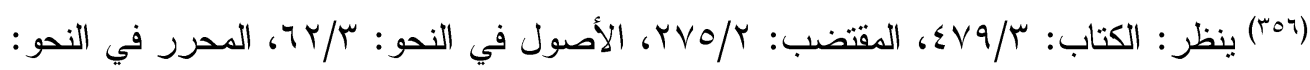

$$
\text { . } \varepsilon 1 \mathrm{l} / 1
$$

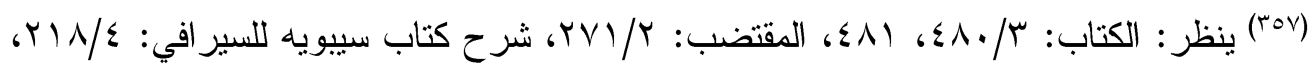

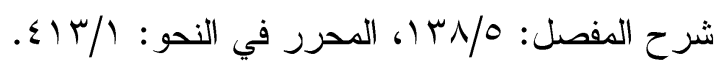



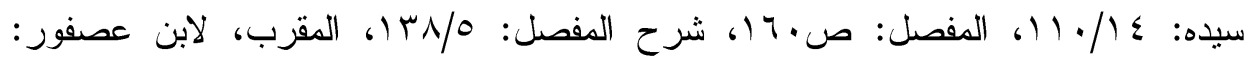

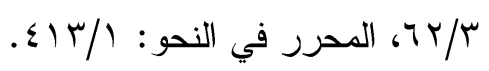

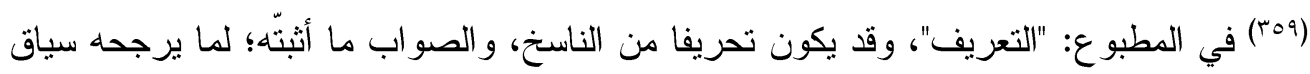

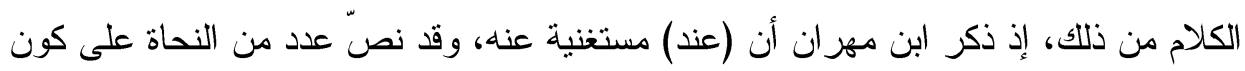

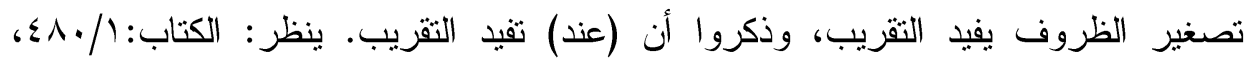

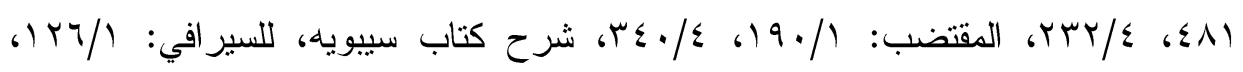

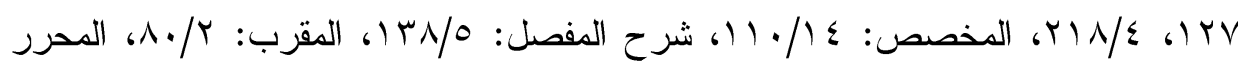

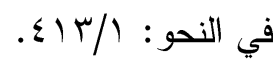

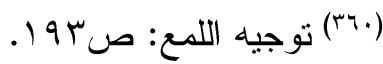

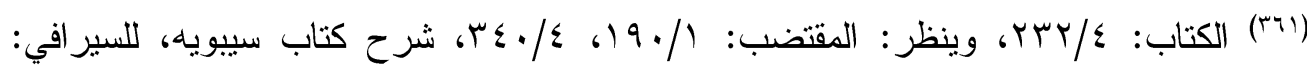

$$
\begin{aligned}
& .1 K V_{6} \mid \mathrm{TT} / 1 \\
& \text { (r) }
\end{aligned}
$$

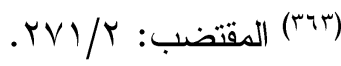

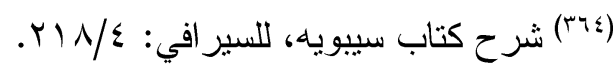

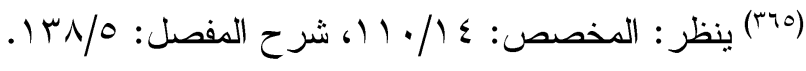

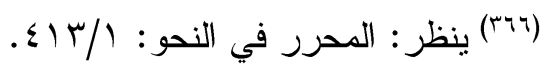

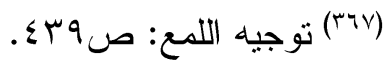

$$
\begin{aligned}
& \text { ( ) }
\end{aligned}
$$

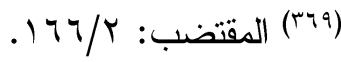




$$
\begin{aligned}
& \text { ( }
\end{aligned}
$$

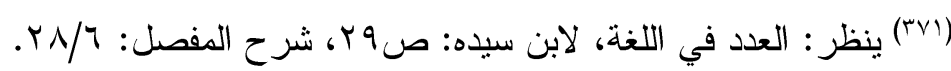

(بVYr)

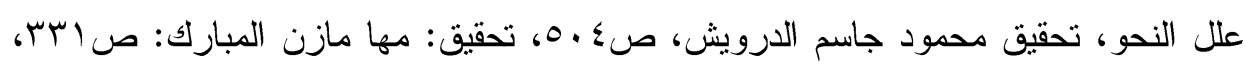

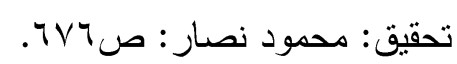

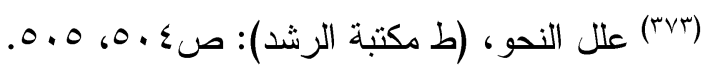

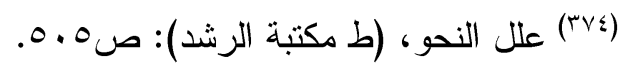

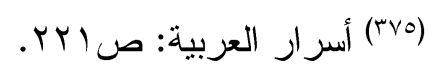

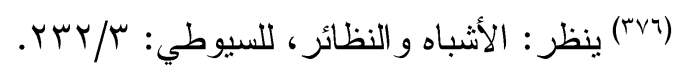

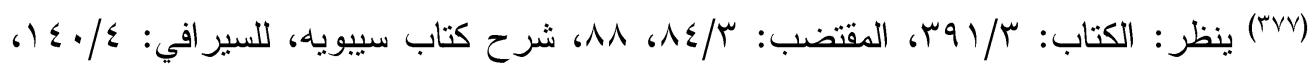

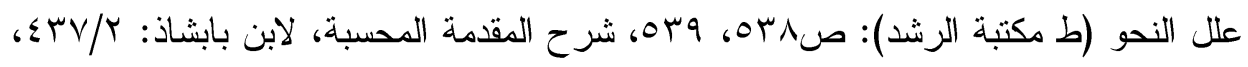

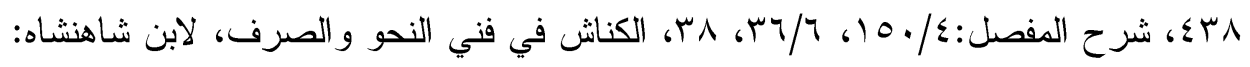

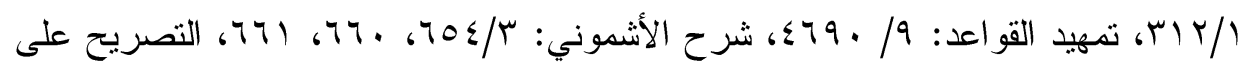

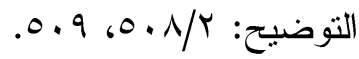

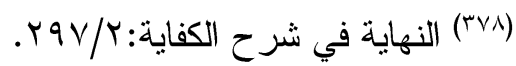

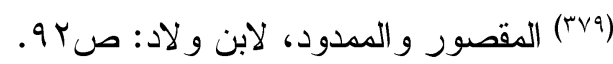

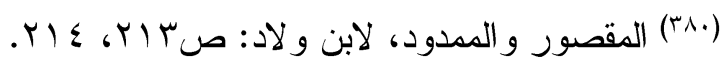

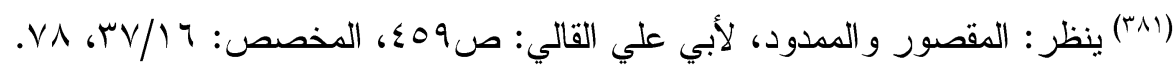

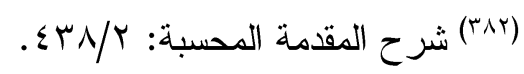

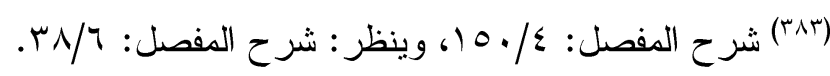

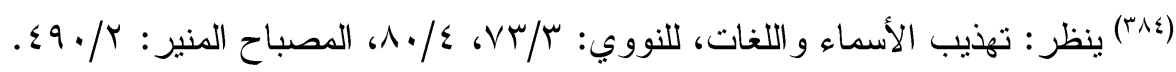

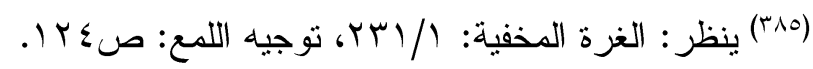

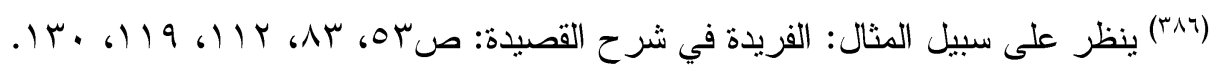

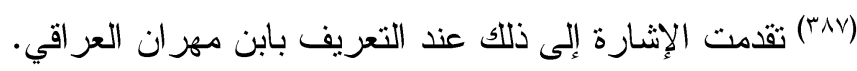

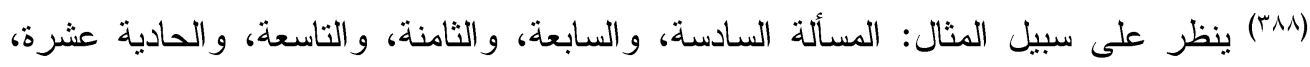

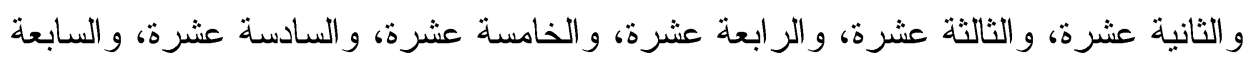

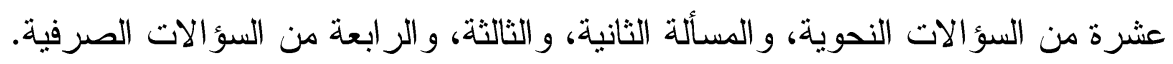




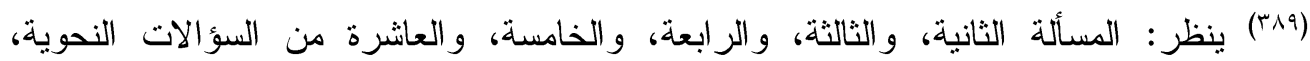

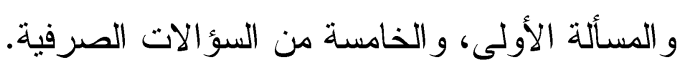

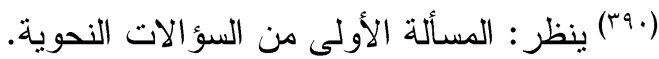

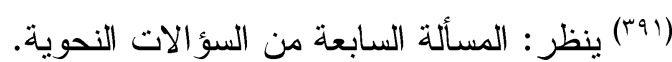

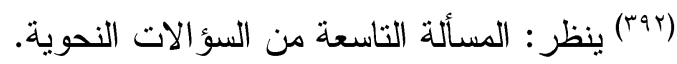

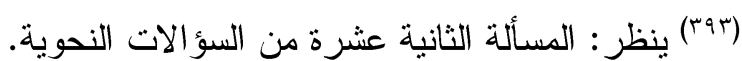

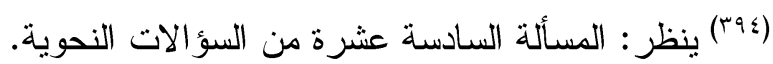

(190) ينظر : المسألة السادسة من السؤ الات النحوية.

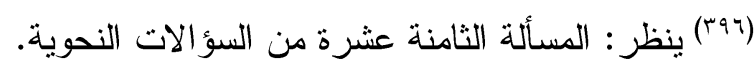

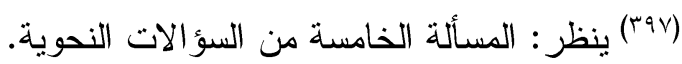

(بی) ينظر : المسألة السابعة من السؤ الات النحوية.

(499) ينظر : المسألة السابعة عشرة من السؤالات النات النحوية.

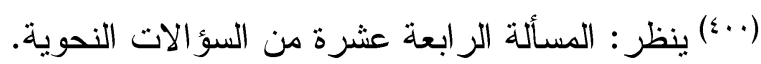

(1) ينظر : المسألة الثالثة من السؤالات النحوية.

(r) ينظر : المسألة الثانية من السؤالات النحوية.

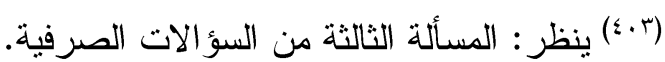

(๕.๕) ينظر : المسألة الأولى من السؤالات الصرفية.

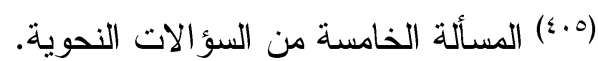

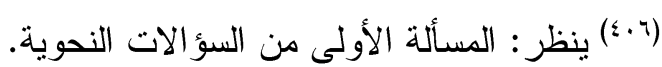

(المسألة الثامنة من السؤالات النحوية.

(ا)

(9.9 (؟) ينظر : المسألة السادسة عشرة من السؤالات النحوية.

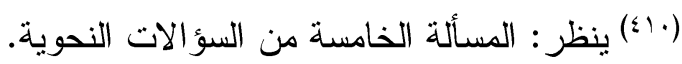

(1) ينظر : المسألة العانشرة من السؤالات النحوية.

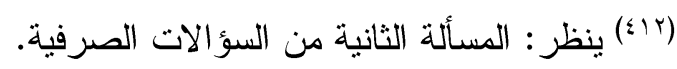

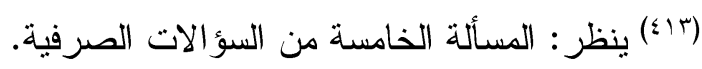

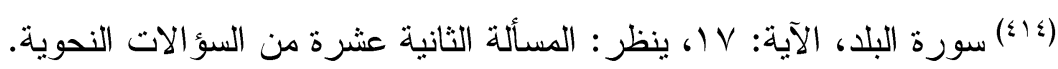


(10) ينظر : المسألة الأولى من السؤالات النحوية.

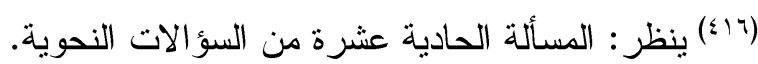

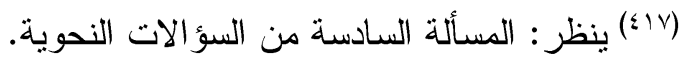
(ا) (19) المسألة الثانية عشرة من السؤالات النحوية.

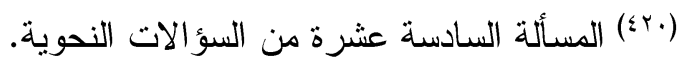
(المسألة السابعة عشرة من السؤالات النحوية.

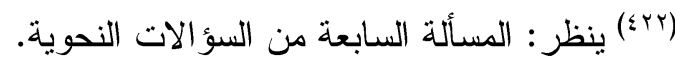

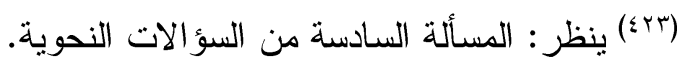

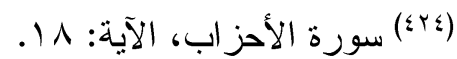

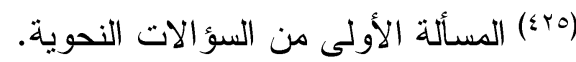

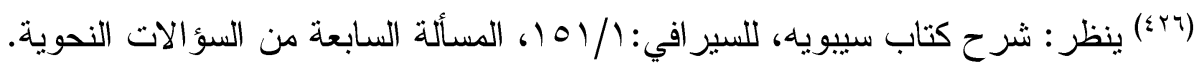

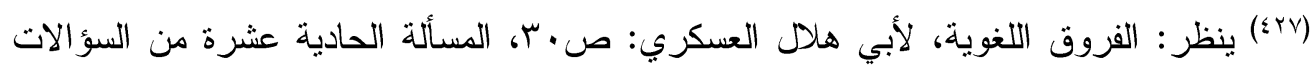

$$
\text { النحوية. }
$$

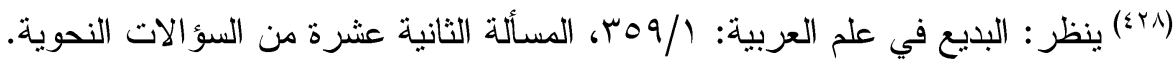

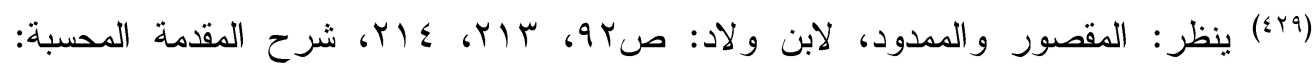

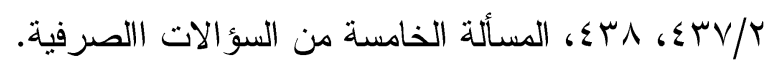

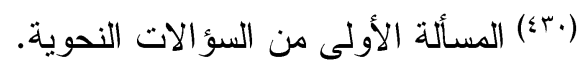

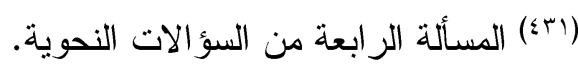

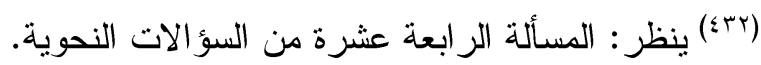

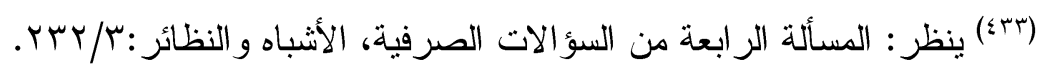

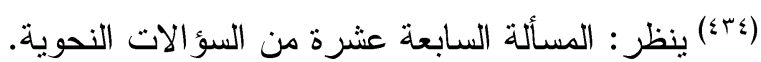

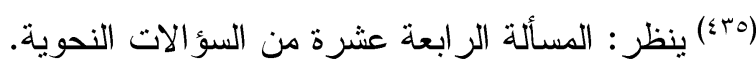
(

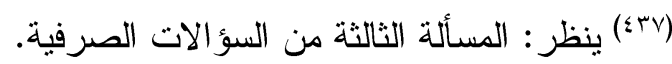

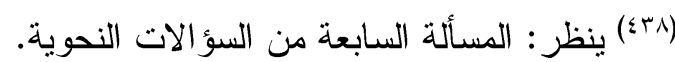
(المج؟) ينظر : المسألة التاسعة من السؤ الات النحوية. 


$$
\begin{aligned}
& \text { (•؛؛؛) ينظر : المسألة الحادية عشرة من السؤالات النحوية. } \\
& \text { (1)؛؛ ينظر : المسألة السادسة عشرة من السؤ الات النحوية. } \\
& \text { (r) ينظر : المسألة الخامسة من السؤالات النحوية. } \\
& \text { (ب) } \\
& \text { (؛ ؛ ؛ ينظر : المسألة الثانية من السؤالات الصرفية. }
\end{aligned}
$$

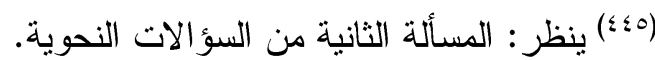

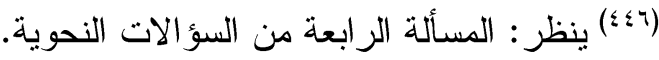

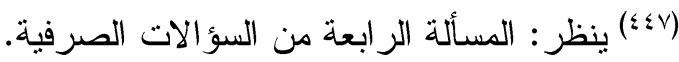

\section{قائمة الإصادروالمراجع}

1- أحكام القرآن، لأبي بكر أحمد بن علي الرازي الجصاص الحنفي (ت: • • آهـ)

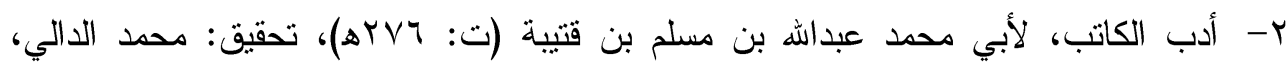

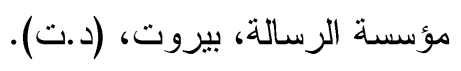

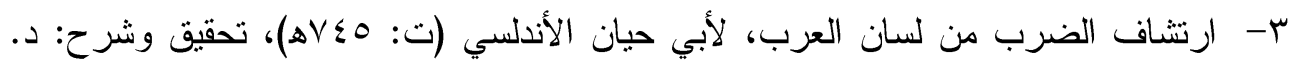

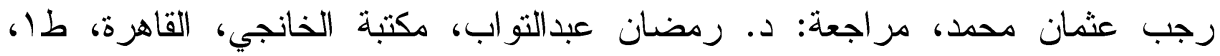

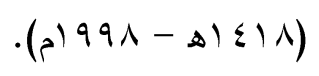

צ- - الإرشاد إلى علم الإعراب، لثمس الدين محمد بن أحمد بن عبداللطيف القرشي الكيشي (ت:

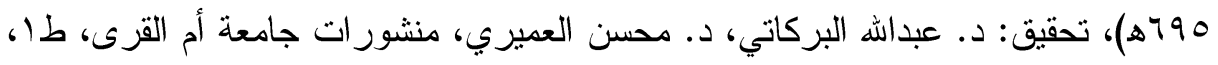

$$
\text { . (م) } 919-8) \leq 1 \cdot)
$$

ه- - الأزهية في علم الحروف، لعلي بن محمد النحوي الهروي (ت: 0 اءه)، تحقيق: عبدالمعين

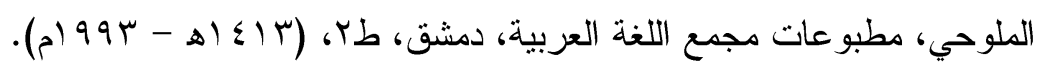

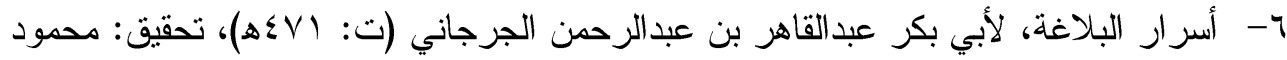

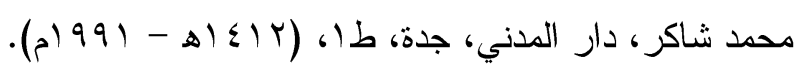

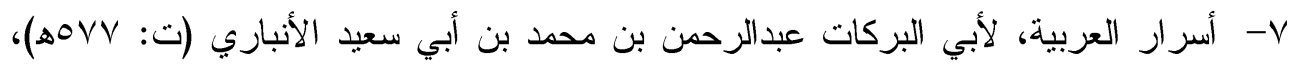
تحقيق: محمد بهجة البيطار، مطبوعات المجمع العلمي العربي، دمشق، (د.ت). ^- الأشباه و النظائر في النحو، لجلال الدين السيوطي (ت: (19)ه)، تحقيق: د. عبدالعال سالم

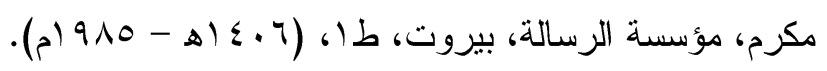


9- الأصول في النحو، لأبي بكر محمد بن سهل بن السرّاج النحوي البغدادي (ت:

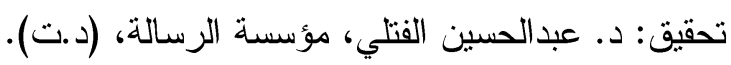

• ا- الأعلام (قاموس تراجم لأثشر الرجال و النساء من العرب والمستعربين والمستشرقين)،

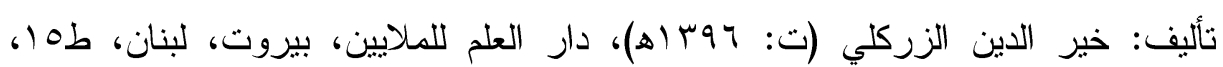

$$
\text { . }
$$

ال- الألغاز النحوية وهو الكتاب المسمى: الطراز في الألغاز، للإمام السيوطي (ت: (1)هـ)،

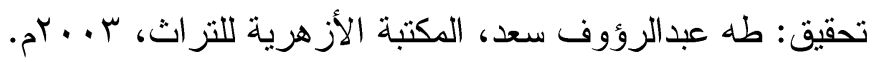

r ا أمالي السهيلي في النحو و اللغة و الحديث و الفقه، لأبي القاسم عبدالرحمن بن عبداله الأندلسي الني

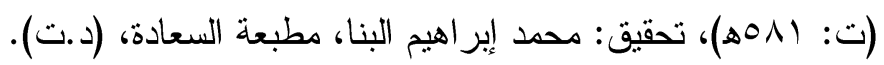

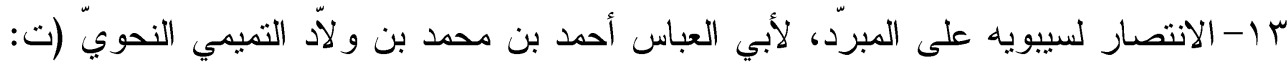

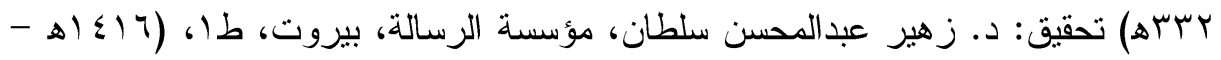
() (م) 997

؛ ا- الإنصاف في التتبيه على المعاني والأسباب التي أوجبت الاختلاف بين المسلمين في آرائهم،

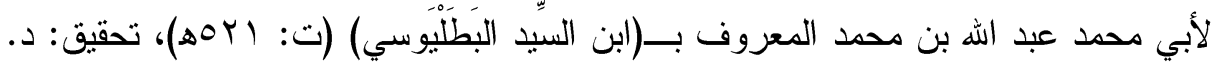

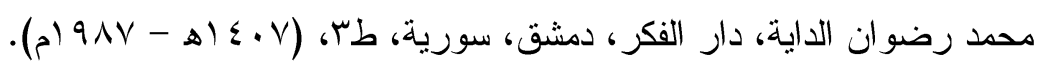

10- الإنصاف في مسائل الخلاف بين النحويين: البصريين و الكوفيين، لكمال الدين أبي البركات

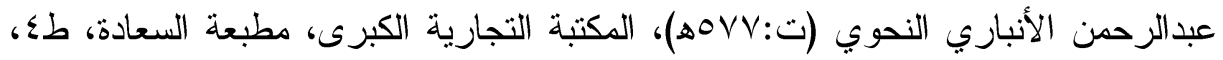

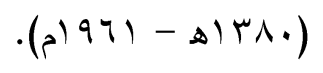

17 -أوضح المسالك إلى ألفية ابن مالك، لأبي محمد عبداله جمال الدين بن يوسف بن هشام

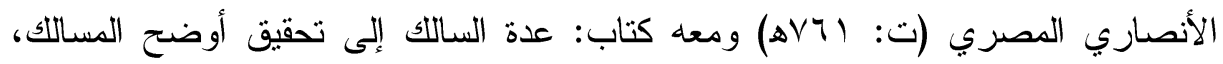

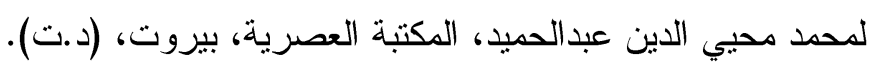

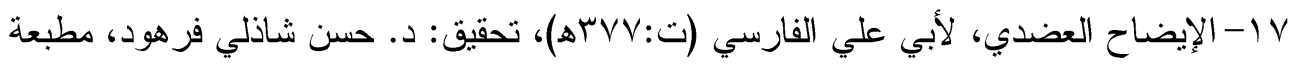

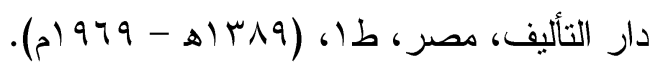

11-الإيضاح في شرح المفصل، لأبي عمرو عثمان بن أبي بكر بن يونس المعروف بــ(ابن

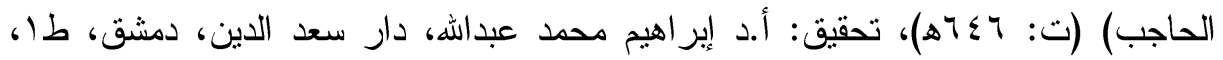

$$
\cdot(r+.0-\Delta) \leq r 0)
$$


9 1-الإِيضاح في علل النحو، لأبي القاسم الزجاجي (ت: • ــاه)، تحقيق: د. مازن المبارك،

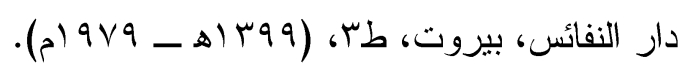

•Y- البحر المحيط، لمحمد بن يوسف الثهير بأبي حيان الأندلسي (ت:

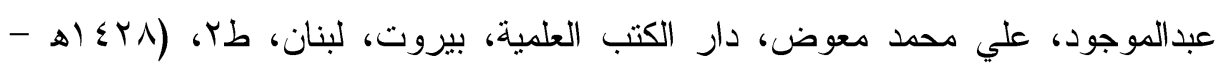

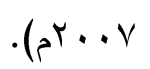

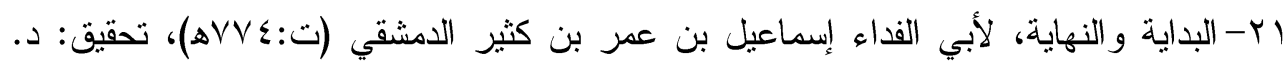

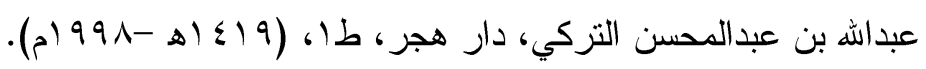

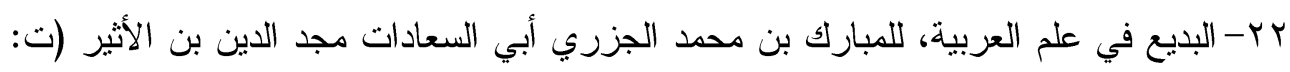

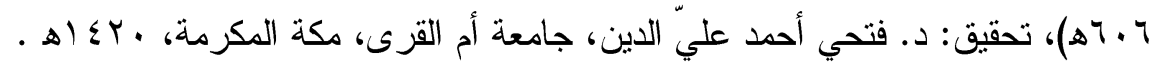

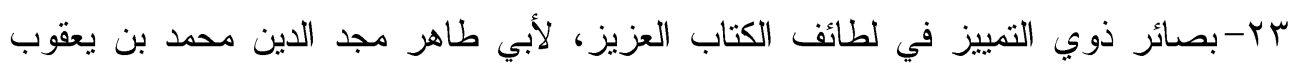

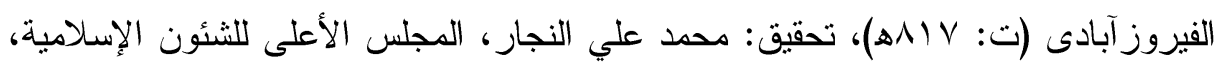

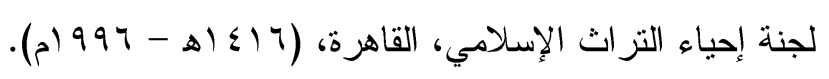

ع ب-بغية الوعاة في طبقات اللغويين والنحاة، لجلال الدين عبدالرحمن السيوطي (ت: (1) (9)ه)،

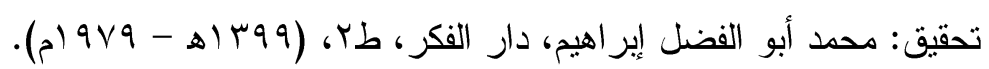

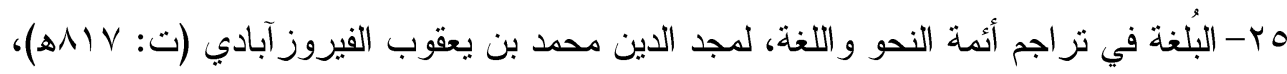

$$
\text { تحقيق: محمد المصري، طبعة منقحة وموسعة، (د.ت). }
$$

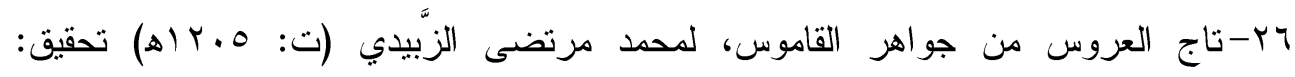

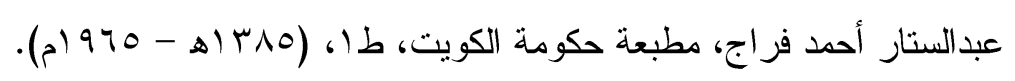

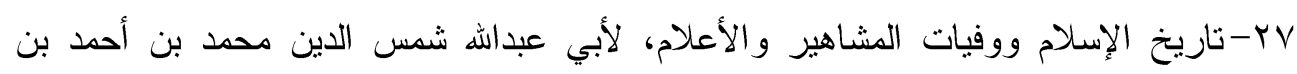

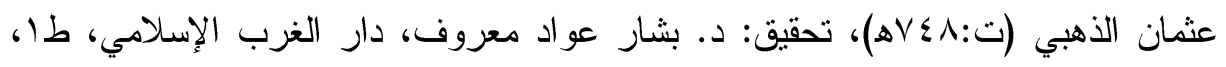

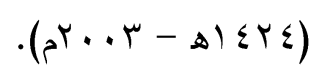

^ץ- التبصرة و التذكرة، لأبي محمد عبداله بن علي الصيمري (من نحاة القرن الرابع)، تحقيق:

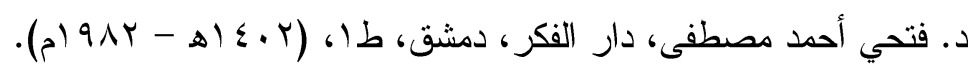

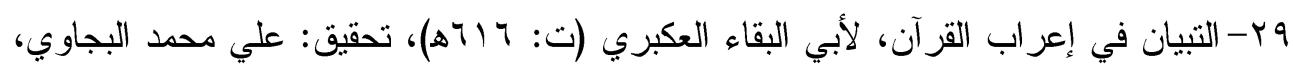

$$
\text { مطبعة عيسى البابي الحلبي وشركاه، (د.ت). }
$$

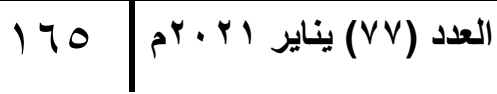


• س- التبيين عن مذاهب النحويين البصريين والكوفيين، لأبي البقاء العكبري (ت: 7 (آهـ) تحقيق: د. عبدالرحمن بن سليمان العثيمين، دار الغرب الإسلامي، بيروت، لبنان، طا، (7 ـ ع اهـ . () 917

اس-تحفة الأديب في نحاة مغني اللبيب، لجلال الدين عبدالرحمن بن أبي بكر السيوطي (ت: (1)هـ)، تحقيق: د. حسن الملخ، د. سهى نعجة، جدارا للكتاب العالمي، عمان، الأردن،

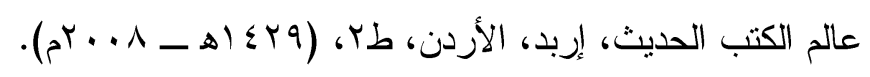

ץس-التحفة الثافية في شرح الكافية في النحو، لأبي عمرو جمال الدين ابن الحاجب (ت: 7 آهـ)، لأبي إسحاق إبراهيم بن الحسين بن عبيداله الطائي النيلي البغدادي، تحقيق: أبو

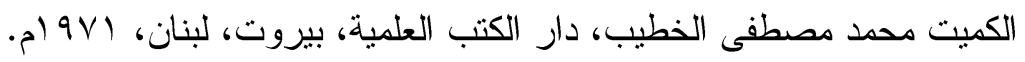
بس- التذييل و التكميل في شرح كتاب التسهيل، لأبي حيان الأندلسي (ت: 0 \اه)، تحقيق: د. حسن هنداوي، دار القلم، دار كنوز إثبيليا، طا، (د.ت).

ع س-التصريح على التوضيح، أو التصريح بمضمون التوضيح في النحو، للشيخ خالد بن عبداله الأزهري (ت: 0.9ه)، تحقيق: محمد باسل عيون السود، دار الكتب العلمية، بيزوت،

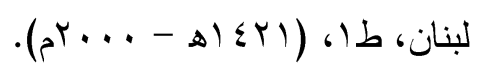

هب-تعليق الفرائد على تسهيل الفوائد، لبدر الدين محمد بن أبي بكر بن عمر الدماميني (ت:AY

بس- التعليقة على كتاب سيبويه، لأبي علي الفارسي (ت:

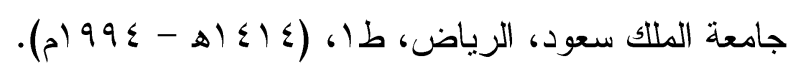

Vr-تلخيص مجمع الآداب في معجم الألقاب، لكمال الدين أبي الفضل عبدالرزاق بن تاج الدين

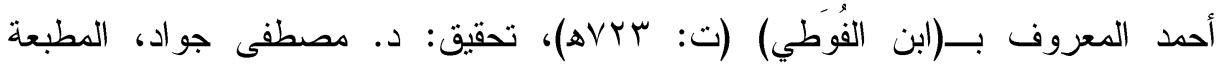
الهاشمية، دمشق، (د.ت).

مب-تمهيد القو اعد بشرح تسهيل الفوائد، لمحب الدين محمد بن يوسف بن أحمد المعروف بناظر

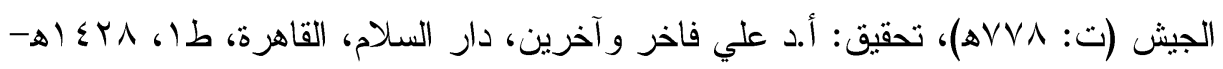

$$
\cdot \cdot r \cdot v
$$

وس- التتبيه و الإيضاح عما وقع في الصحاح، لأبي محمد عبدالله بن برّي المصري (ت: rمهـ)، تحقيق: أ. عبدالوهاب عوض الله، د. عبدالحميد مذكور، مجمع اللغة العربية، الإدارة العامة

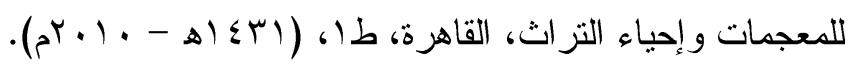




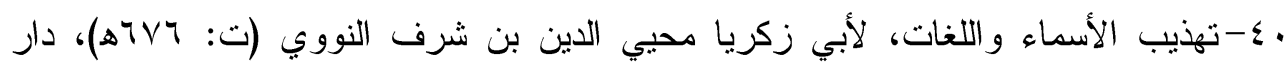

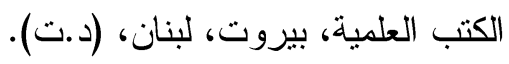

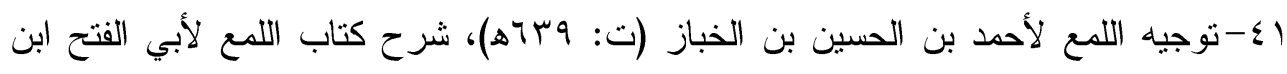

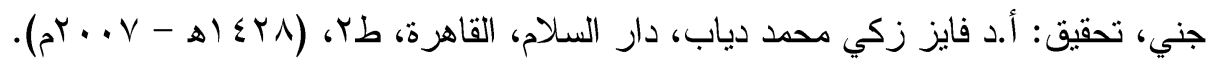

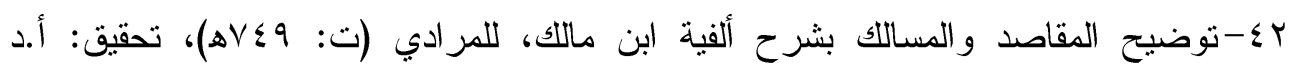

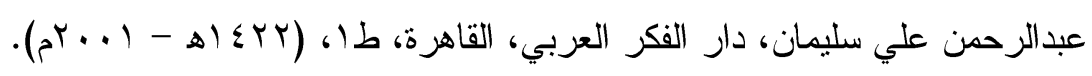

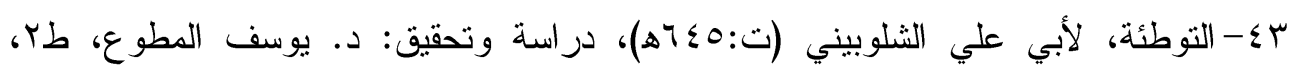

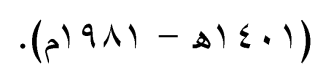

ـ ؟- الجمل في النحو، لأبي القاسم عبدالرحمن بن إسحاق الزجاجي (ت: ــآه)، تحقيق: د.

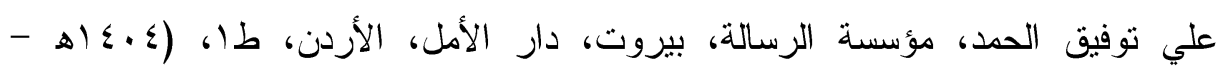
(م) $9 \wedge \varepsilon$

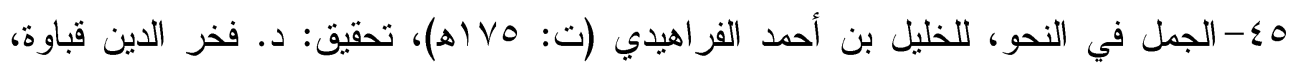

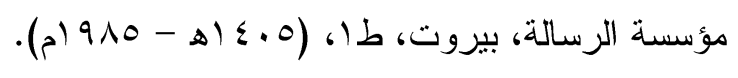

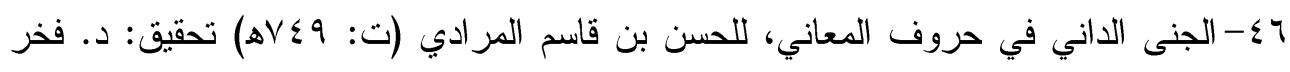

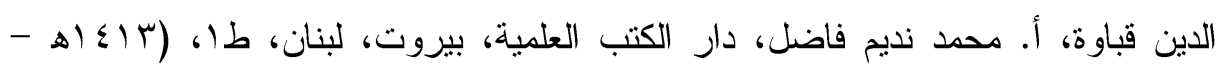
. (م) (a)

V V - حاثشية الخضري على شرح ابن عقيل على ألفية ابن مالك، للثيخ محمد الخضري الدمياطي

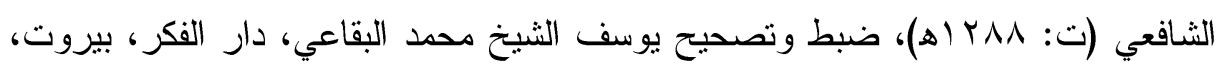

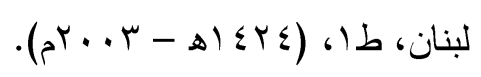

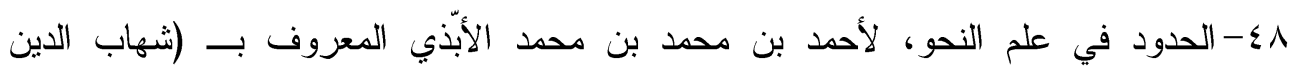
الأندلسي) (ت: . . الجده)، تحقيق: نجاة حسن عبدالله نولي، الجامعة الإسلامية، المدينة

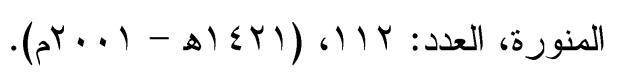

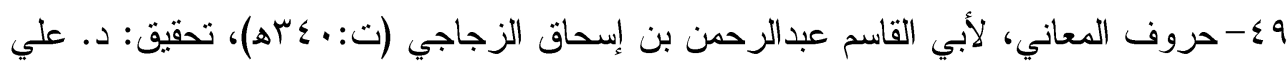

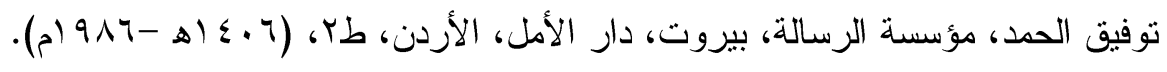

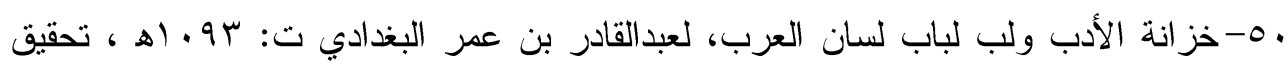

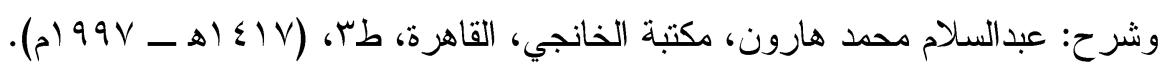


اه- الدر المصون في علوم الكتاب المكنون، لأحمد بن يوسف المعروف بــ (السمين الحلبي) (ت:

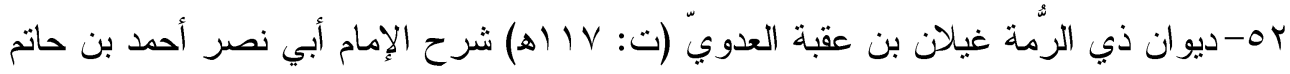

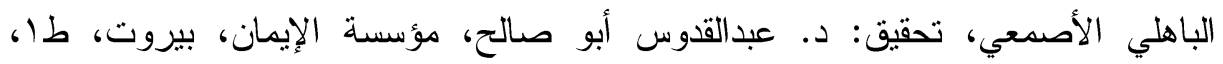

$$
\text { . (م) } 9 \wedge r-ه) \varepsilon \cdot r)
$$

به-ديوان زهير بن أبي سلمى (ت: 9 . جم)، اعتىى به وشرحه: حمدو طماس، دار المعرفة،

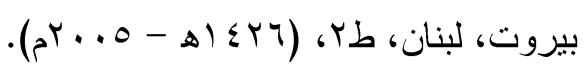

عه-رصف المباني في شرح حروف المعاني، لأحمد بن عبدالنور المالقي (ت: r • Vه)، تحقيق: أحمد محمد الخر اط، مطبوعات مجمع اللغة العربية بدمشق، (د.ت). هـ-سر صناعة الإعراب، لأبي الفتح عثمان بن جني (ت: بوسه) تحقيق: د. حسن هنداوي،

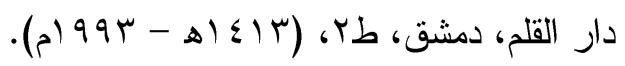

7ه-شذرات الذهب في أخبار من ذهب، لابن العماد الحنبلي (ت:19 • اهـ) تحقيق: عبدالقادر

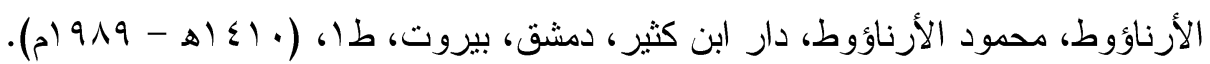
Vo-شرح ابن الناظم على ألفية ابن مالك، لأبي عبداله بدر الدين محمد بن جمال الدين محمد بن

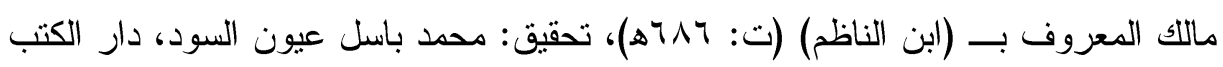

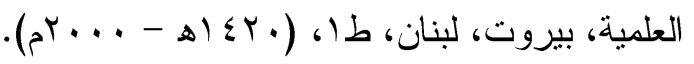

^ه-شرح ابن عقيل بهاء الدين عبداله بن عقيل العقيلي المصري الهمذاني (ت: ألفية ابن مالك، ومعه كتاب منحة الجليل بتحقيق شرح ابن عقيل، لمحمد محيي الدين

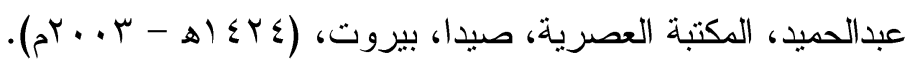

9ه-شرح الأشموني على ألفية ابن مالك المسمّى منهج السالك إلى ألفية ابن مالك، لأبي الحسن

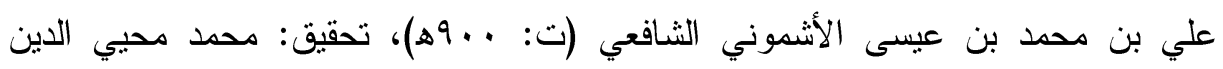

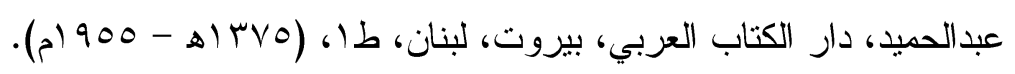

• צ-شرح التسهيل، لابن مالك جمال الدين محمد بن عبداله الطائي الجياني الأندلسي (ت: كا

$$
\text { ط) }
$$

آ-شرح التصريف، لأبي القاسم عمر بن ثابت الثمانيني (ت: r؟ §ه)، تحقيق: د. إبراهيم بن سليمان البعيمي، مكتبة الرشد، طا، (9 (1 اله -999 (م). 
با-شرح الرضي لكافية ابن الحاجب، لرضي الدين محمد بن الحسن الاستراباذي (ت: Ү1/4ه)،

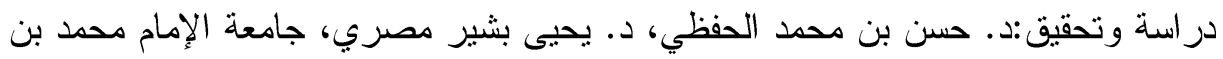

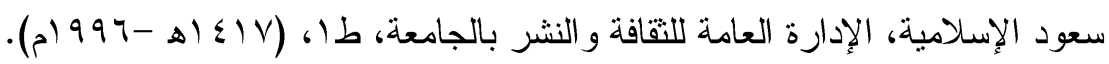

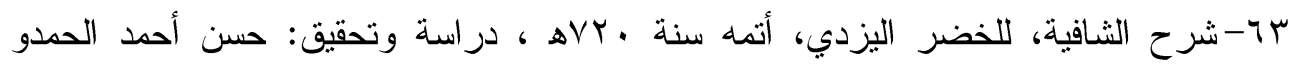

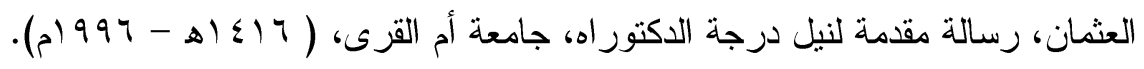

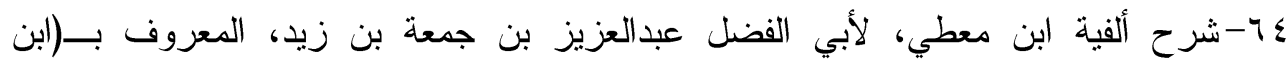

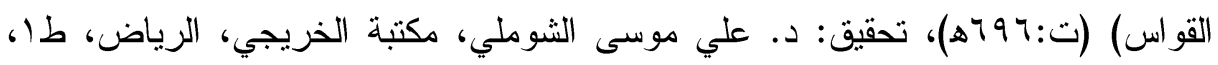

$$
.(1910-ه) \leqslant 00)
$$

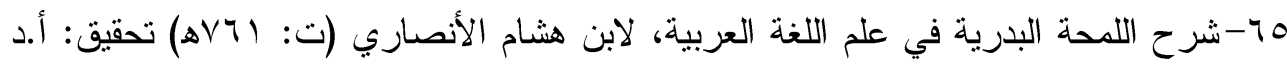

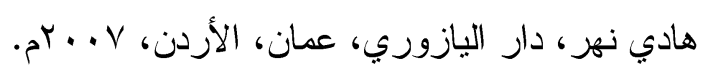

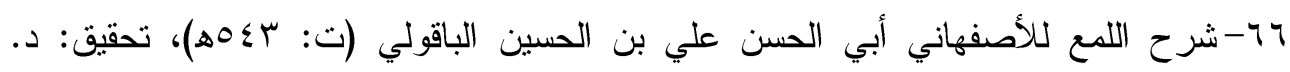
إبراهيم بن محمد أبو عباة، إدارة الثقافة والنشر بجامعة الإمام محمد بن سعود الإنسلامية،

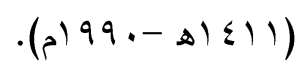

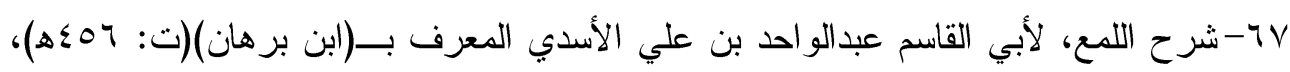

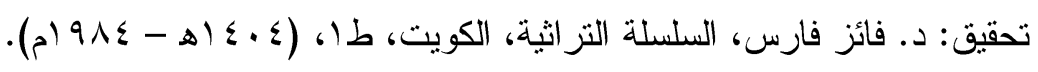

1^-شرح المفصل، لابن علي بن يعيش النحوي (ت: بـ آه)، إدارة الطباعة المنيرية، (د.ت).

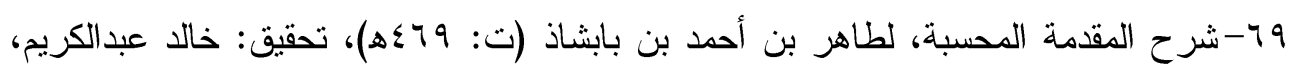

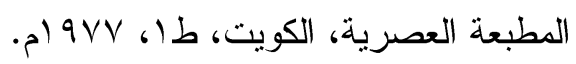

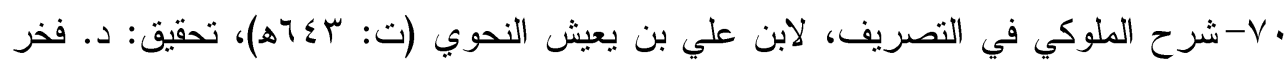

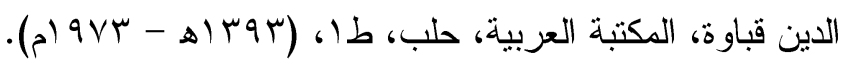

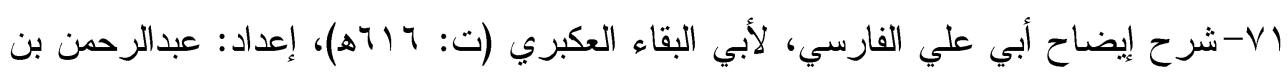

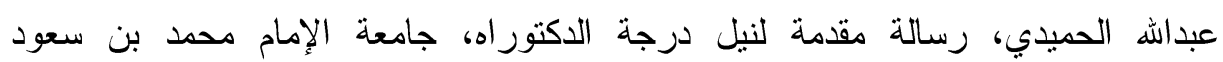
الإسلامية، 9 . ع أهـ 

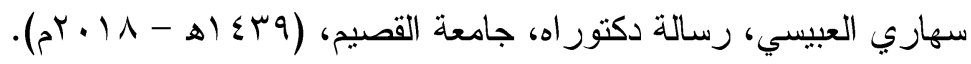

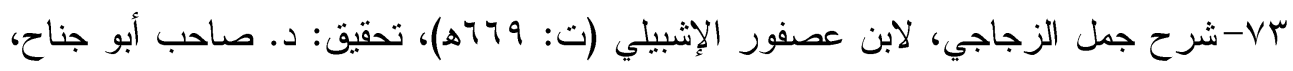
(ت.د) 


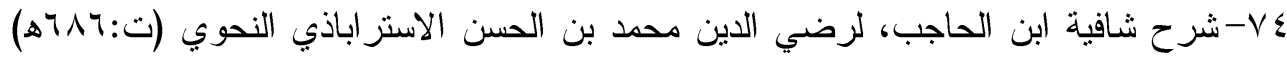

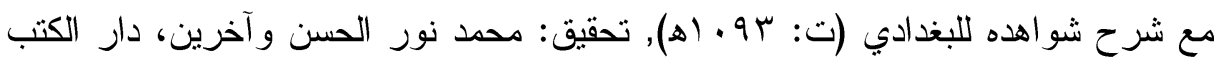

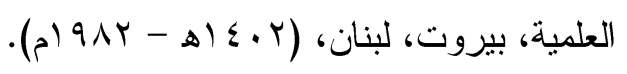

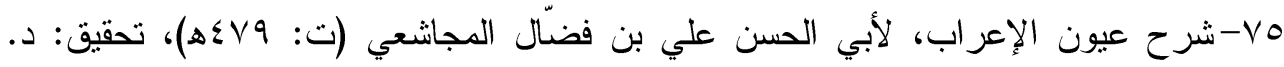

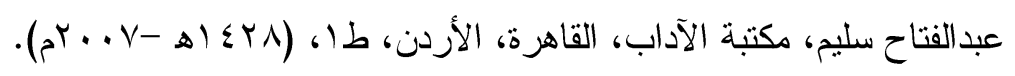

TY-شرح قطر الندى وبل الصدى، لأبي محمد عبداله جمال الدين بن هشام الأنصاري

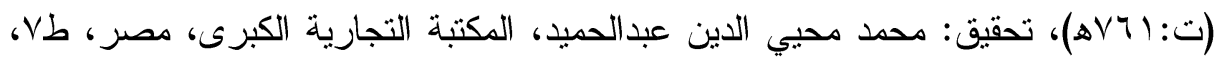

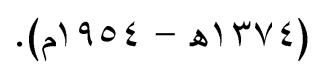

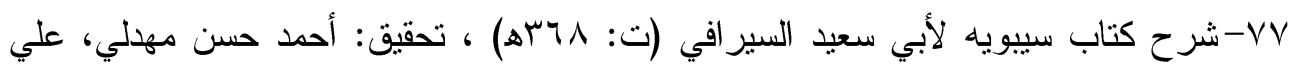

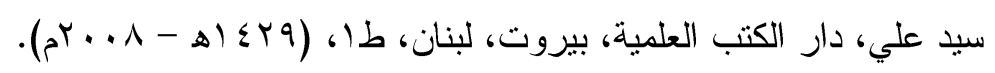

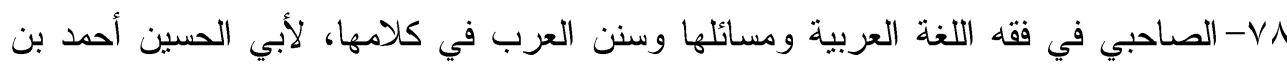

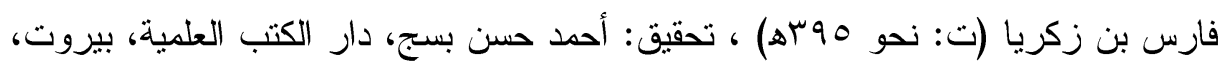

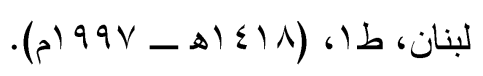

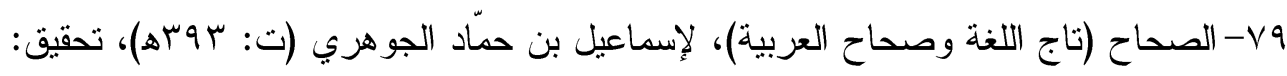

$$
\text { أحمد عبدالغفور عظّار، دار العلم للملايين، (د.ت). }
$$

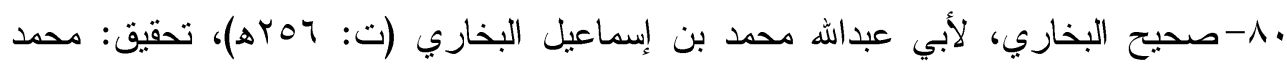

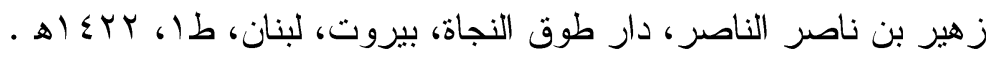

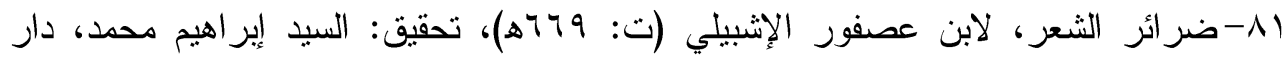

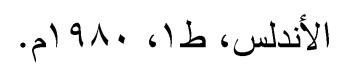

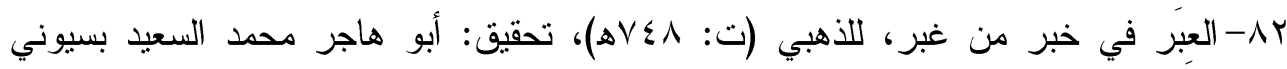

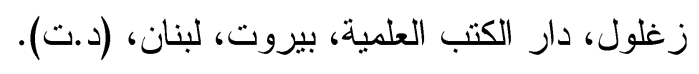

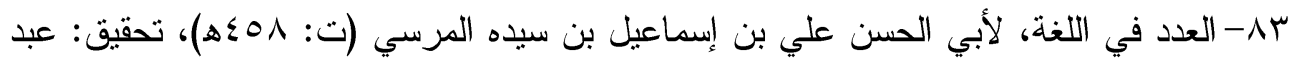

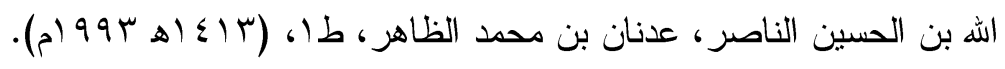

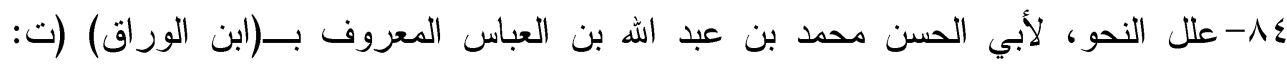

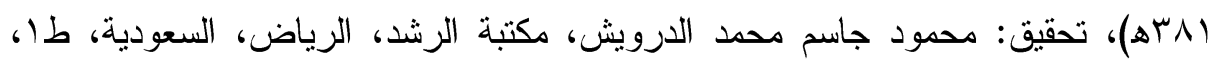

$$
\cdot(\text { (م) } 999-\Delta 1 \leq r \cdot)
$$


هـ- علل النحو، لأبي الحسن محمد بن عبد الله بن العباس المعروف بــ(ابن الوراق) (ت:

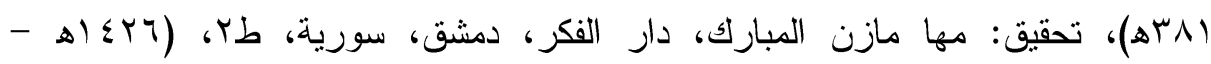
$\cdot(5, \cdot 0$

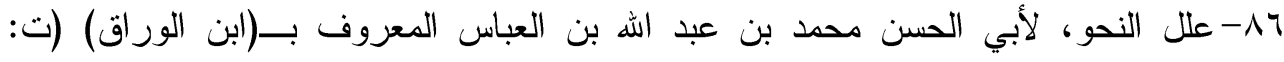

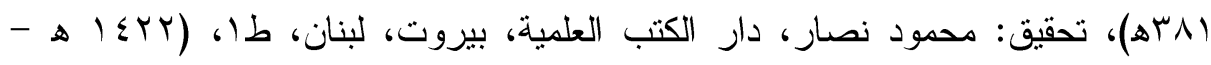

$$
\left.\cdot()^{2} \cdot+\right)
$$

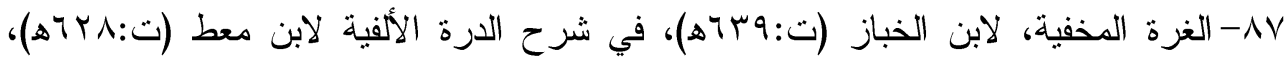

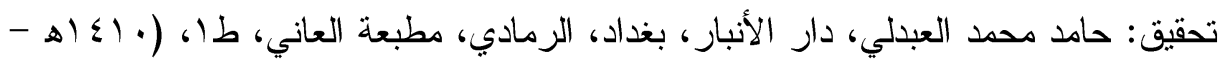

$$
\text { . (5) }
$$

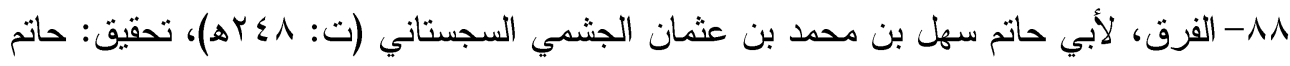

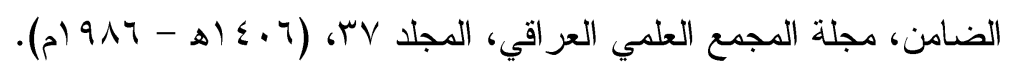

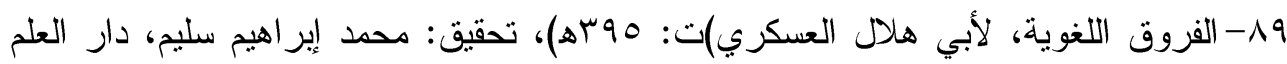

$$
\text { و الثقافة، القاهرة، (د.ت). }
$$

• 9- الفريد في إعراب القرآن المجيد، للمنتجب الهذاني (ت: بـآه)، تحقيق: محمد نظام الدين

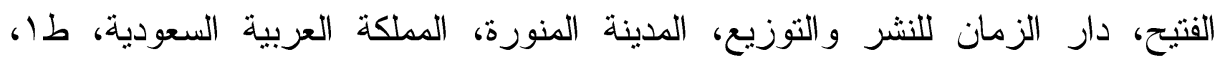

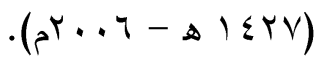

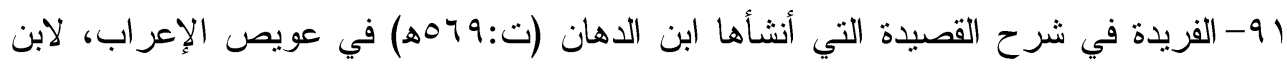

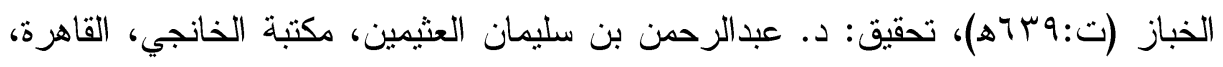

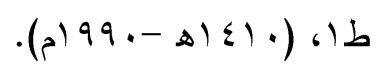

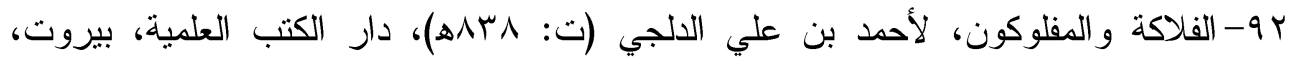

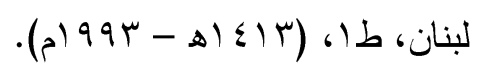

بو-قلائد الجمان في فرائد شعراء هذا الزمان، لكمال الدين أبي البركات المبارك بن الثنعار

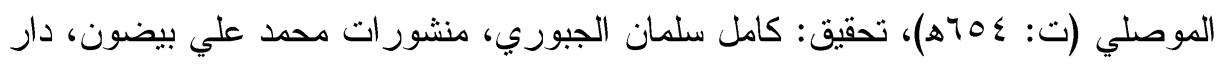

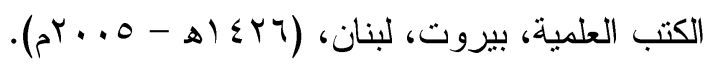

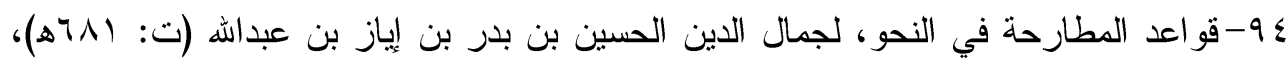

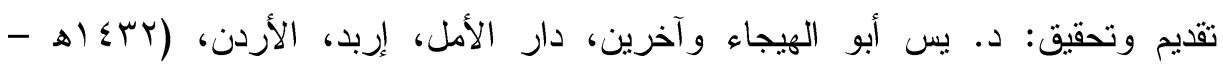

$$
\left.\cdot()^{2} \cdot 1\right)
$$


09- القو اعد والفوائد، لعمر بن ثابت الثمانيني (ت: بـ گه)، تحقيق: د. عبدالوهاب محمود

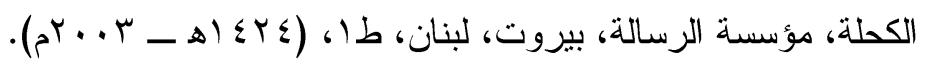

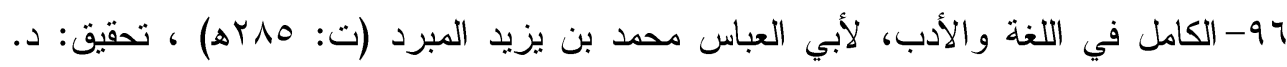

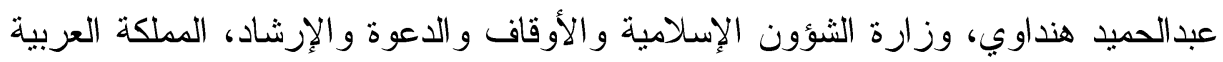

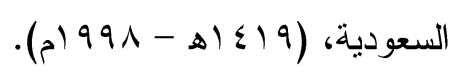

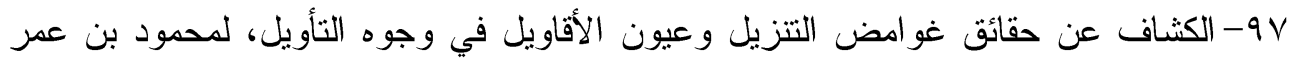

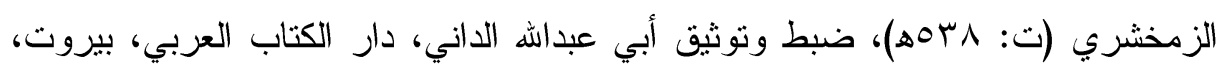

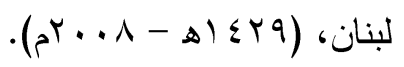

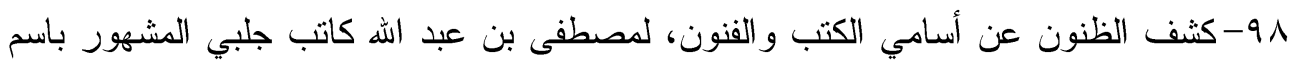

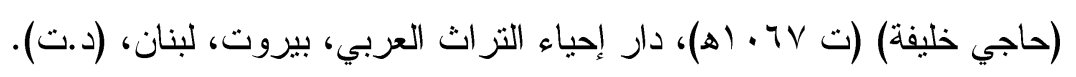

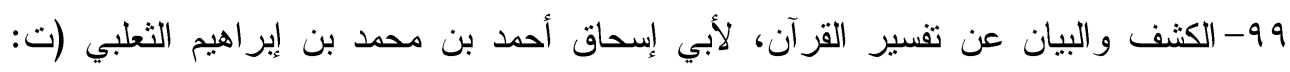

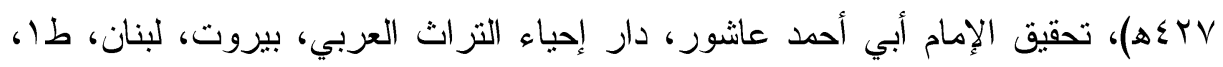

$$
(\text { ( } r \cdots r-\Delta) \leq r r)
$$

. . . الكليات (معجم في المصطلحات و الفروق اللغوية)، لأبي البقاء أبوب بن موسى الحسيني

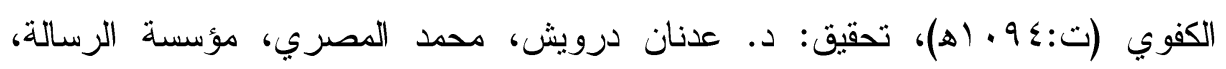

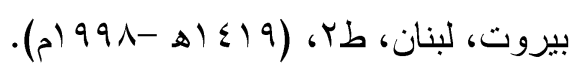

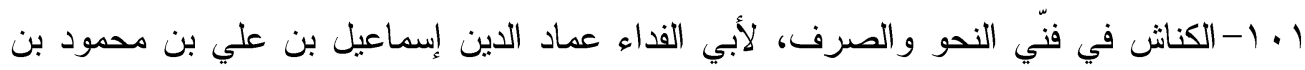

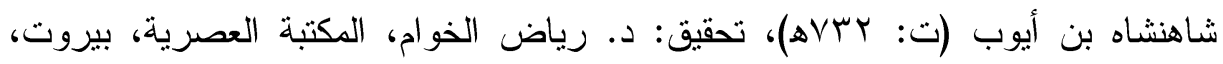

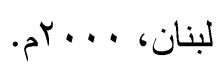

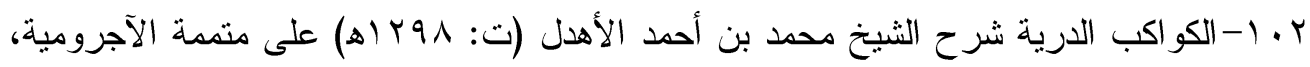

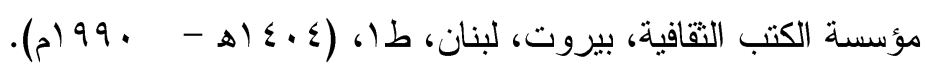

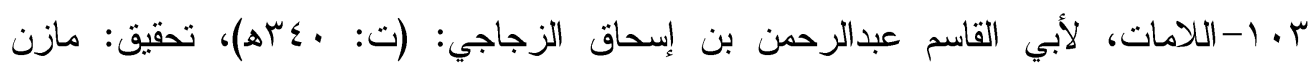

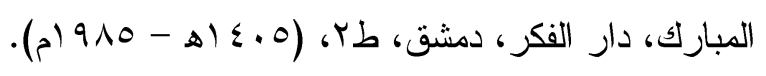

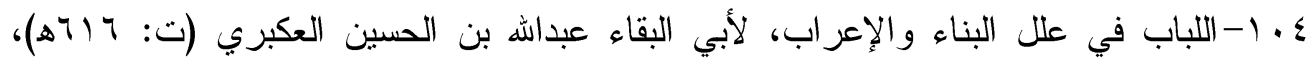

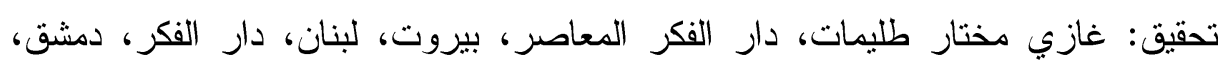

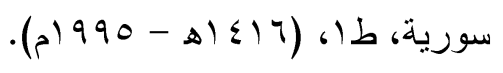

ه. 1-لسان العرب لأبي الفضل جمال الدين محمد بن مكرم المعروف بـــ(ابن منظور) الإفريقي 


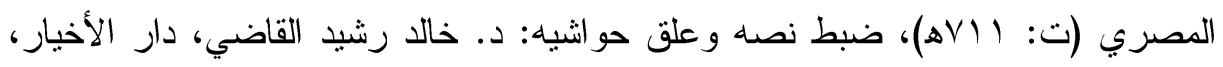

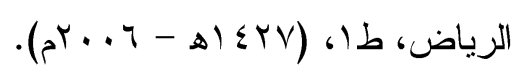

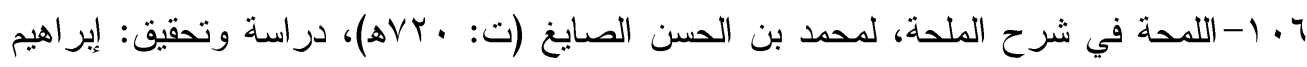

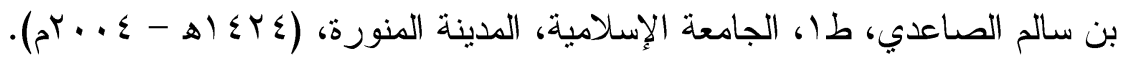

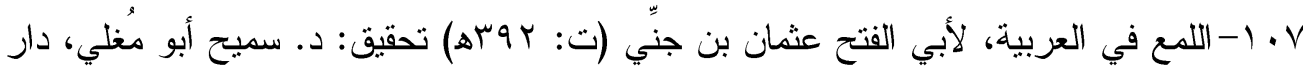

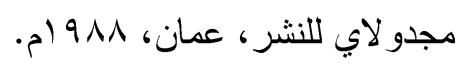

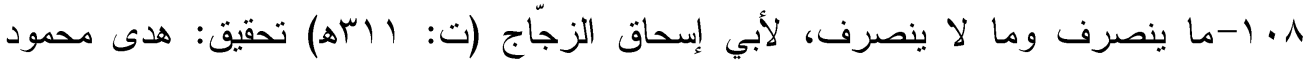

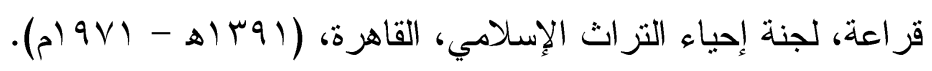

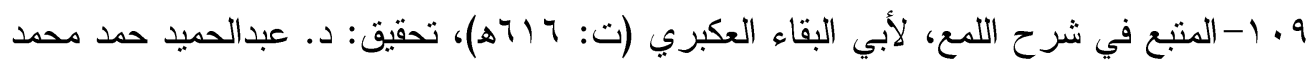

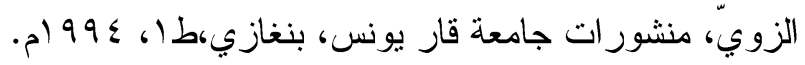

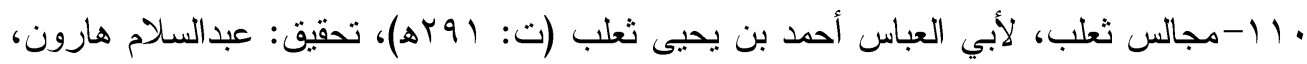

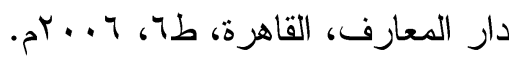

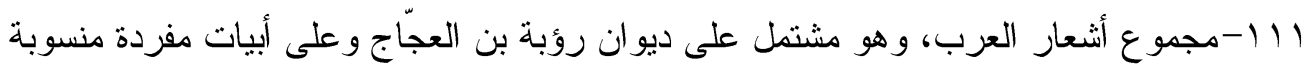

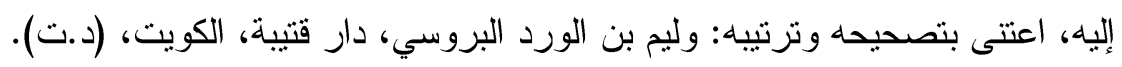

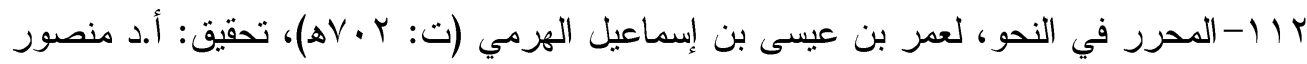

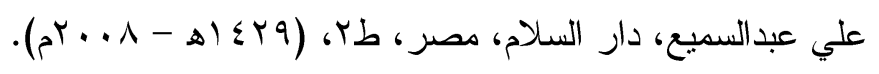

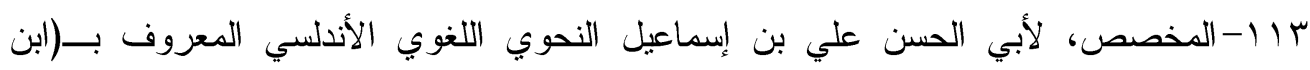

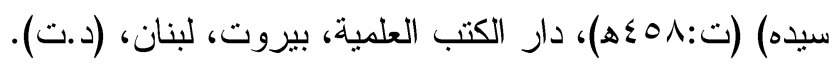

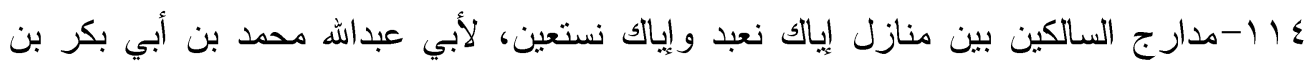

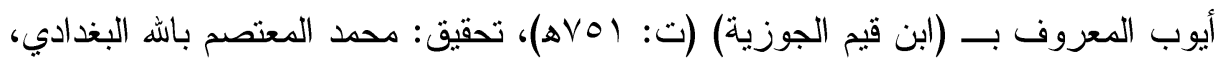

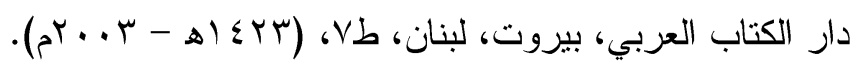

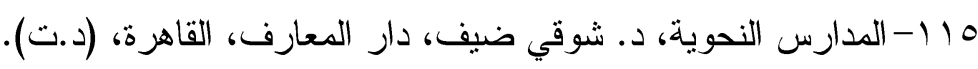

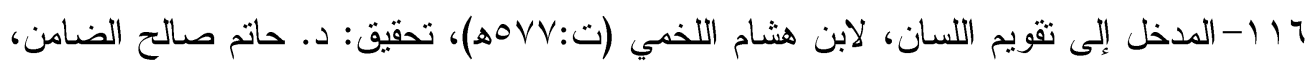

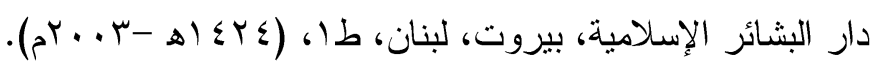

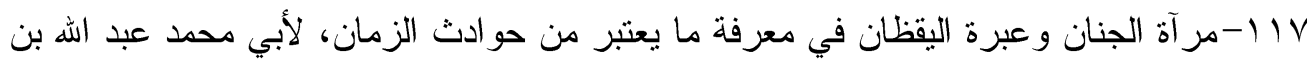

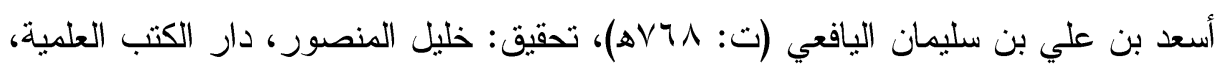

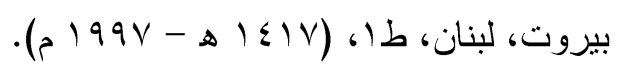


11 المرتجل، لأبي محمد عبداله بن أحمد ابن الخشاب (ت: VTهـ)، تحقيق: علي حيدر،

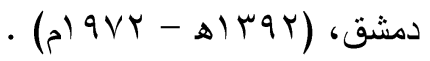

9 1 ا- المساعد على تسهيل الفو ائد، شرح منقّح لابن عقيل على كتاب التسهيل لابن مالك، تحقيق: د. محمد كامل بركات، مركز البحث العلمي وإحياء التراث الإسلامي، مكة المكرمة،

$$
\text { . (م) } 91 .-\infty) \leq \cdots)
$$

• r ا المسائل البصريات، لأبي علي الفارسي (ت: ITVV)، تحقيق: د. محمد الثاطر أحمد محمد

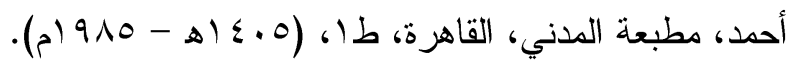

ا Y ا-المسائل العسكريات في النحو العربي، لأبي علي الفارسي (ت: YVVهـ)، تحقيق: أ.د. علي

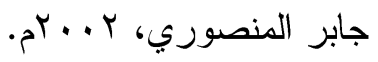

r ا - المسائل المشكلة المعروفة بالبغداديات، لأبي علي الفارسي (ت: VVVه)، تحقيق: صلاح الدين عبداله السنكاوي، مطبعة العاني، بغداد، (د.ت).

rr إ-المسائل المنتورة، لأبي علي الحسن بن أحمد بن عبدالغفار الفارسي (ت:MVV) تحقيق

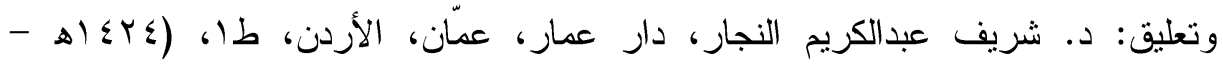

$$
\cdot()^{2} \cdot \cdot \varepsilon
$$

ع ז -مساللك الأبصار في مماللك الأمصار، لابن فضل الله العُريّ، شهاب الدين أحمد بن يحيى (ت: 9 \اه)، تحقيق: كامل سلمان الجبوري، دار الكتب العلمية، بيروت، لبنان، طاه،

$$
\cdot r^{2} \cdot 1 \text {. }
$$

ه ا - المصباح المنير في غريب الشرح الكبير للرافعي، لأحمد بن محمد بن علي الفيومي (ت: •هV) .

بr -المصطلح النحوي نشأته وتطوره حتى أواخر القرن الثالث الهجري، د. عوض حمد

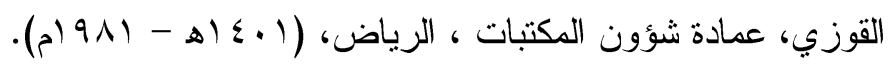

I IV

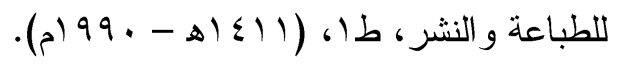

^ץ ا-معاني الحروف، لأبي الحسن علي بن عيسى الرماني النحوي (ت: ع^اهـ)، تحقيق: د.

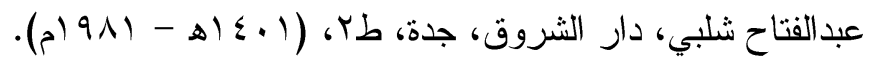

وץ ا-معاني القرآن، لأبي جعفر النحاس (ت: ^شبه)، تحقيق: محمد علي الصابوني، جامعة أم

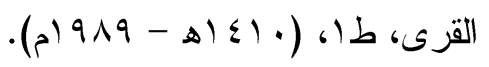


•rا-معجم البلدان، لأبي عبداله شهاب الدين ياقوت بن عبداله الحموي البغدادي (ت: كبآه)،

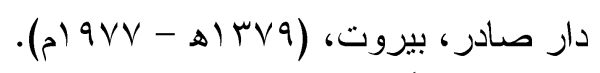

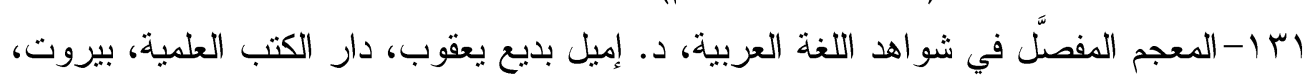

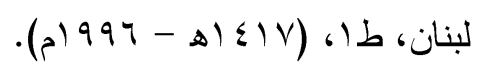

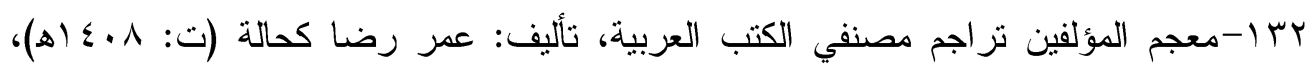

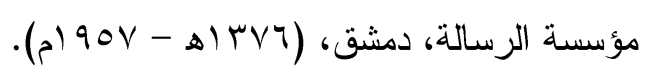

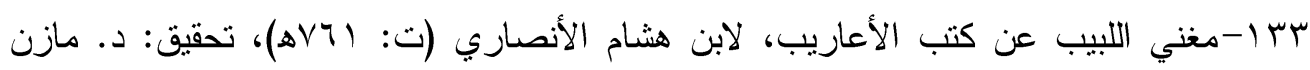

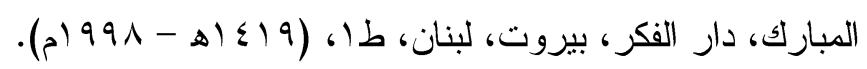

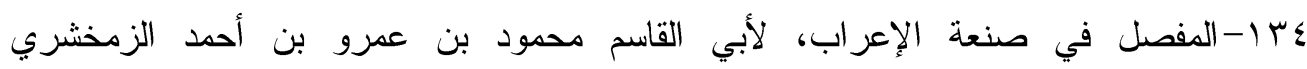

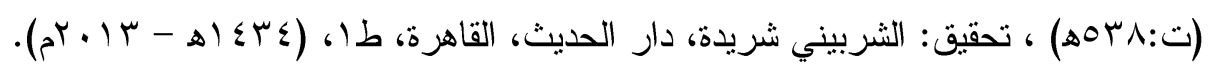

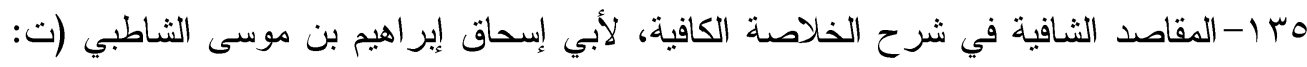
.

$$
\cdot(r+\cdot V-\Delta) \leqslant r \Lambda)
$$

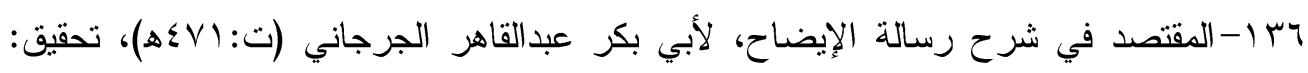

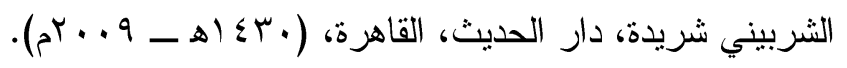

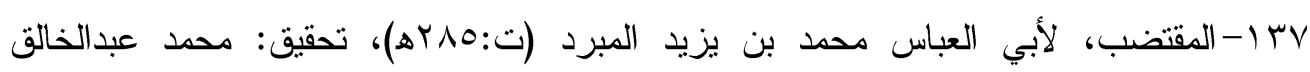

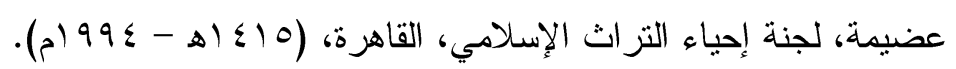

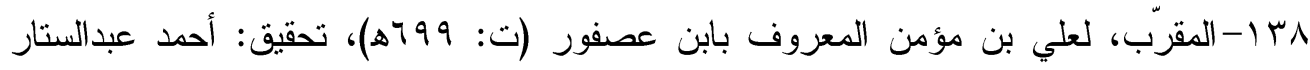

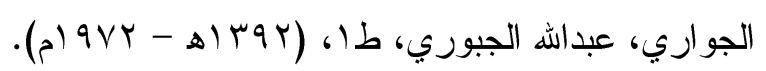

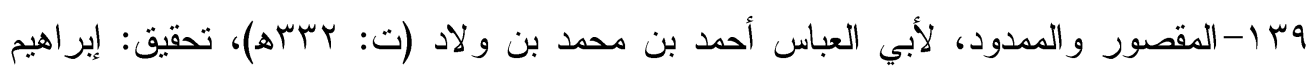

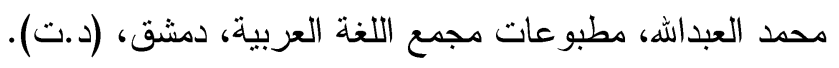

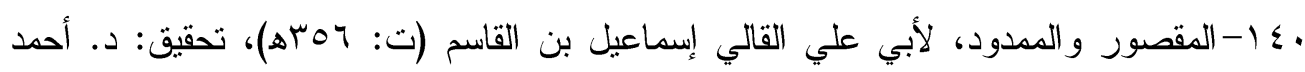

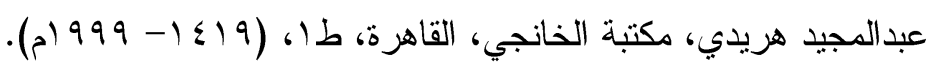

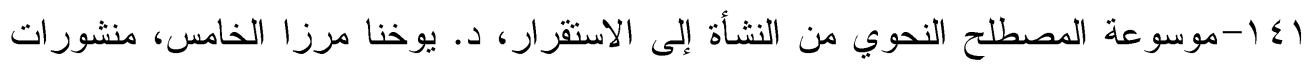

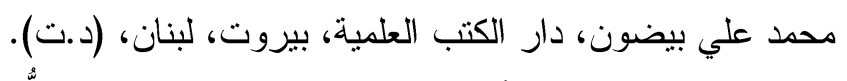

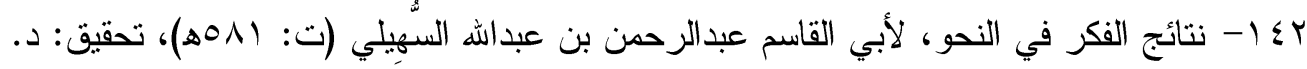

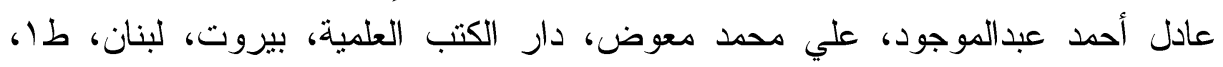

$$
\text { .(م) (99r-ه) - (1) }
$$


بـ ا- النجوم الزاهرة في ملوك مصر و القاهرة، لجمال الدين أبي المحاسن يوسف بن تغري بردي

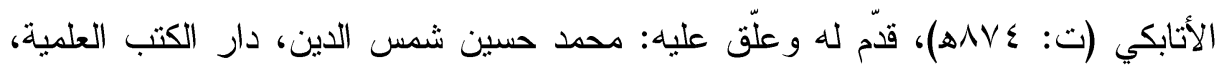

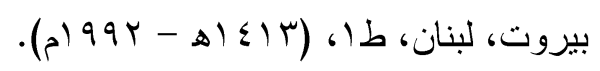

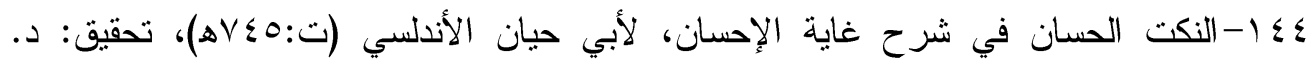

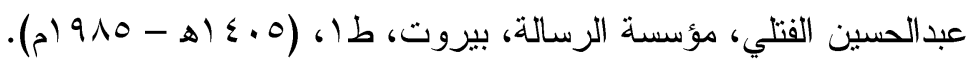

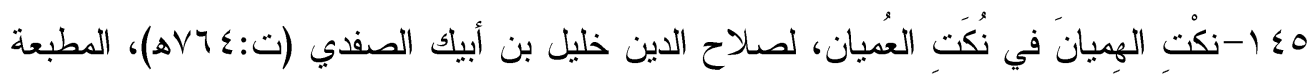

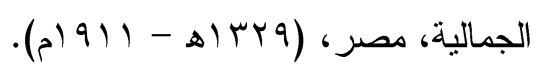

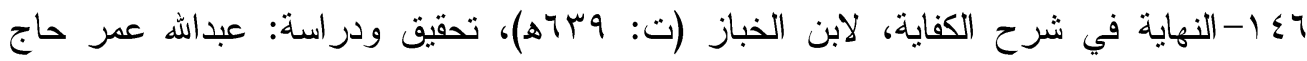

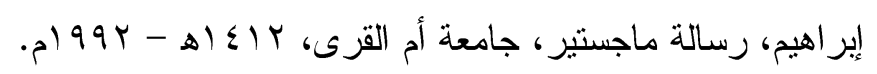

V V ا-النهاية في غريب الحديث و الأثر، للإمام مجد الدين أبي السعادات المبارك بن محدم

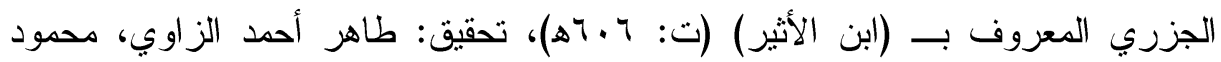

$$
\text { الطناحي، المكتبة الإسلامية، (د.ت). }
$$

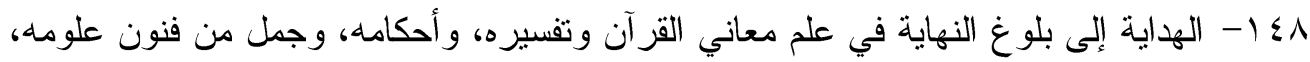

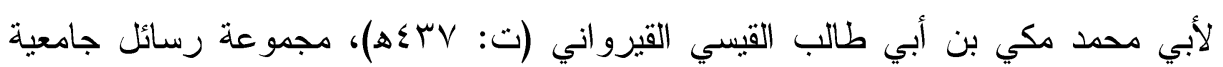

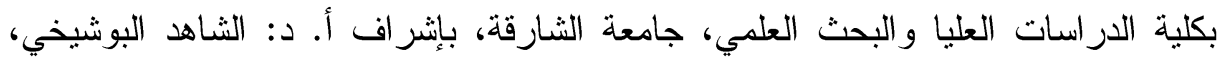

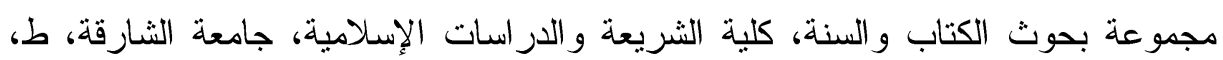

$$
\text { . (مr. }
$$

9 ا-هدية العارفين أسماء المؤلفين و آثار المصنفين، لإسماعيل باشا البغدادي (ت: 99 9 اهـ)،

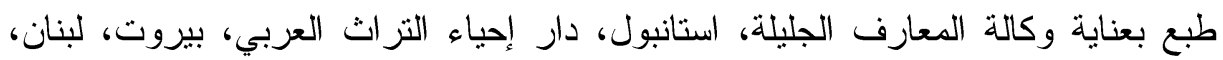

$$
.01901
$$

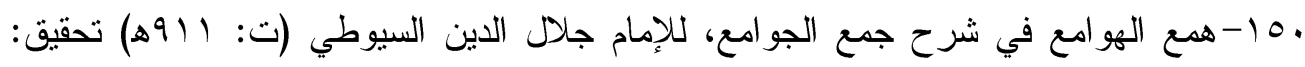

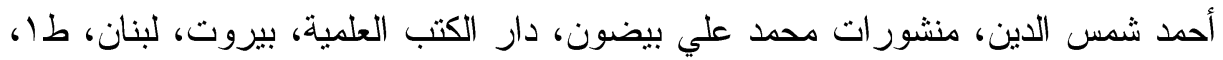

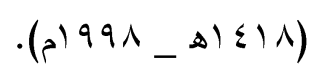

101-الوافي بالوفيات، لصدلاح الدين خليل بن أيبك الصفدي (ت: \& \&Yه)، تحقيق: أحمد

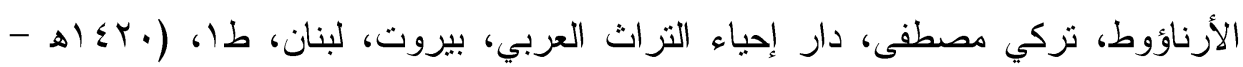

